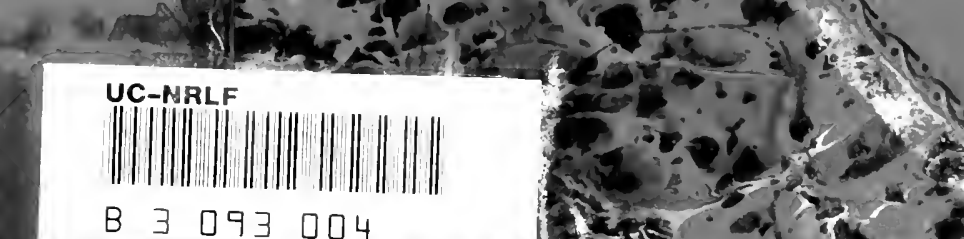

B 3093004

IIts

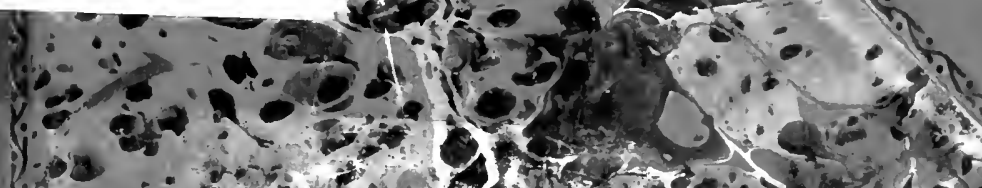

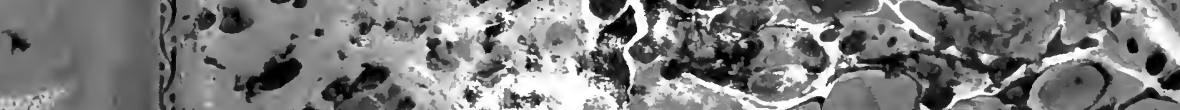

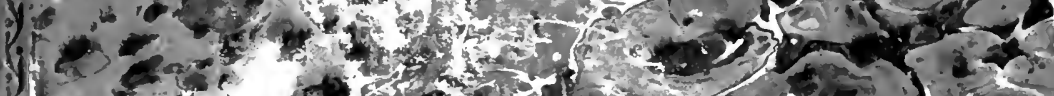

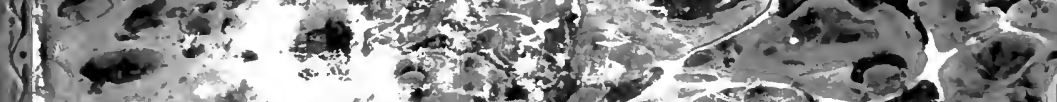

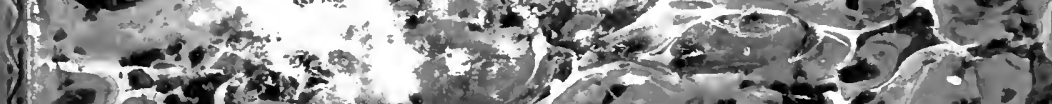

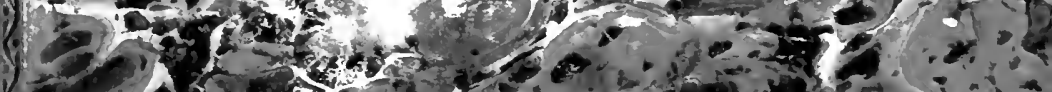

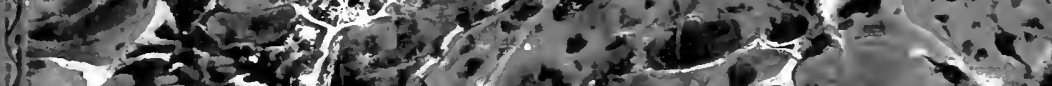

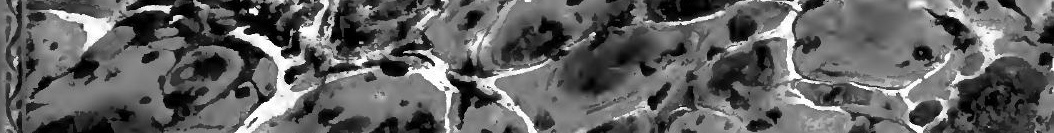

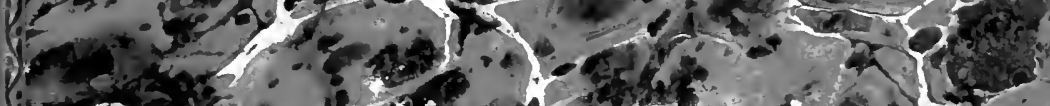

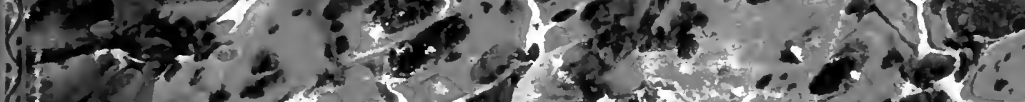

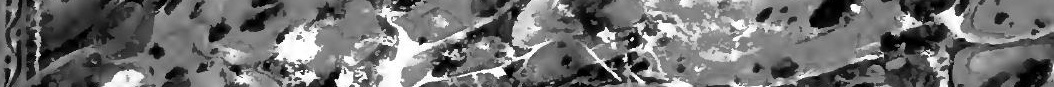

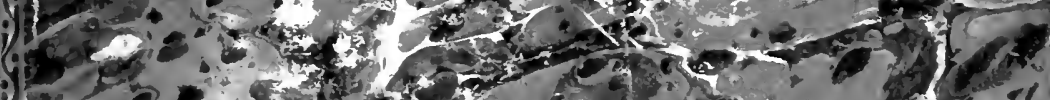

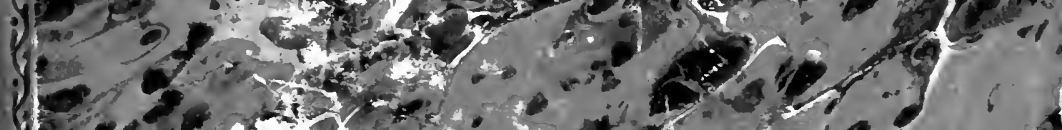

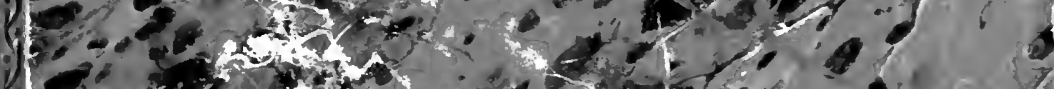

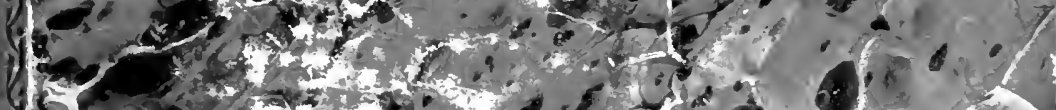

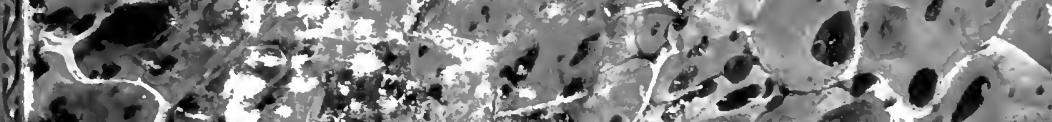

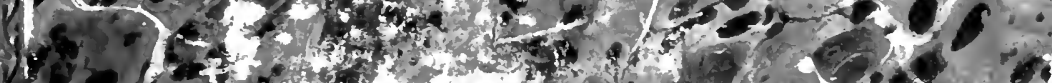

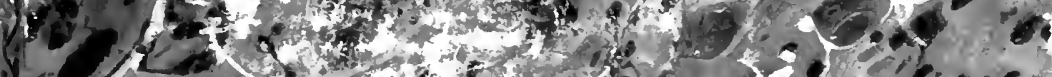

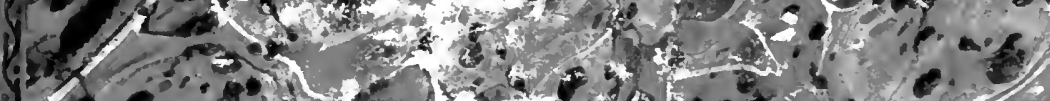

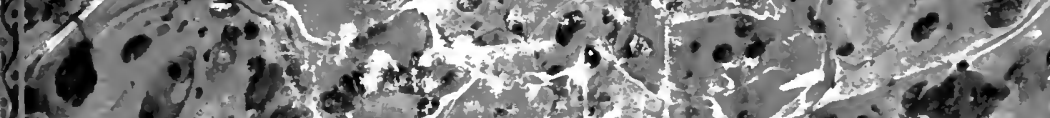

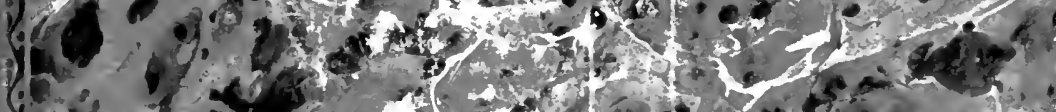
1)

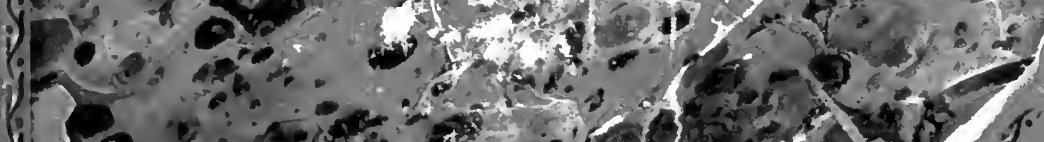

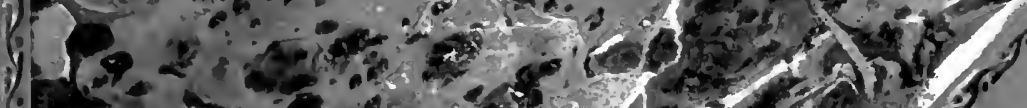

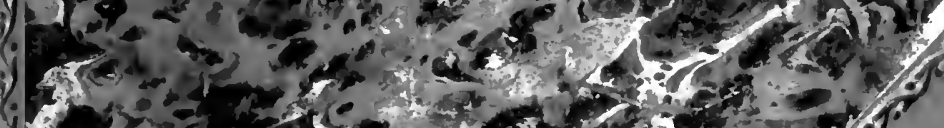

$x$ osents

$+3+2 x^{2}$

11 $-3 x^{2}-2$ (2) 


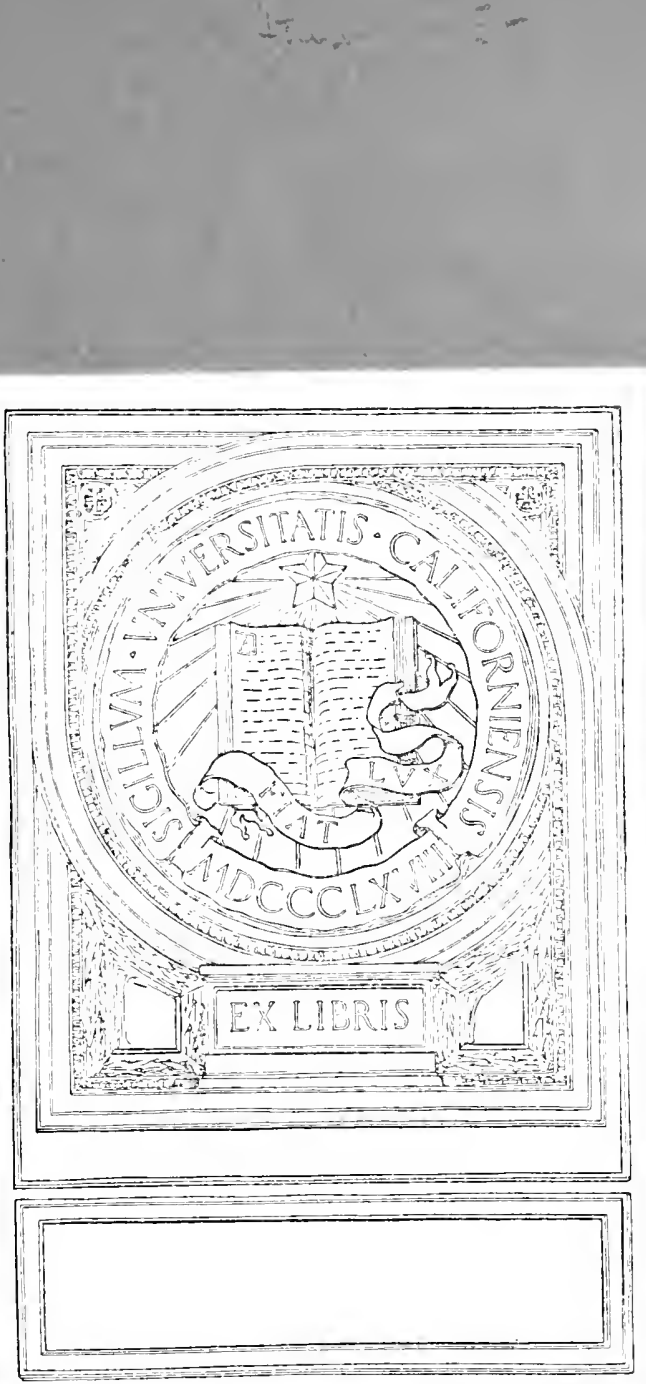


Digitized by the Internet Archive in 2008 with funding from Microsoft Corporation 


\section{SECOND SERIES.}

\section{CONTRIBUTIONS}

TO THE:

\section{LITERATURE OF THE FINE ARTS}

BY

SIR CHARLES LOCK EASTLAKE, F.R.S., D.C.L., \&o. LATE PRESIDENT OF THE ROYAL ACADEMY, AND DIRECTOR OF THE NATIONAL GALLERT.

\section{WITH A MIENOIR}

COMPILED BY LADY EASTLAKE.

LONDON :

JOHN MURRAY, ALBEMARLE STREET. 1870. 
LONDON :

fradrury, eVANS, aND Co, PRINTERs, Whitefriars.

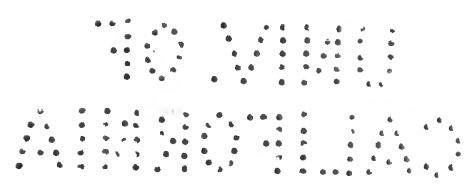




\section{CONTENTS.}

\section{MEMOIR OF SIR CHARLES EASTLAKF.}

\section{CHAPTER 1.}

Analysis of character.-Birth, family, and education.-Plympton Grammar School.- The Charter House.-Haydon.-Resolution to be an historical painter.-First Studies at Royal Academy.-Sir Charles Bell.-Mr. Jeremiah Harman.-First commission for a picture.-Turner.-History of John Eastlake.

\section{CHAPTER II.}

Severe winter--Expedition to Calais.-Louis the Eighteenth and Duchesse d'Angoulême.-Retumn to London.-Visit to Paris.Copying in the Louvre.-The splendours of the Louvre Gallery in 1815.-Remarks on principal pictures.-Admiration of Titian.Leaves Paris on return of Napoleon. - The Bellerophon in Plymouth Sound.-Portrait of Napoleon.-Journey to Rome.

\section{CHAPTER III.}

First impressions of Rome.-Mr. Cockerell.-Dr. Bunsen.-English Society.-Naples.-Tivoli.-Enthusiasm for Italian landscape.Starts for Greece-CCorfu.-Zante,-Patras.-Delphi.--Corinth.Khemil Bey.-The Plague.-Athens.-Sicily.-Return to Rome. . 61

\section{CHAPTER IV.}

Captain and Mrs. Graham.-Sir Thomas Lawrence in Rome.-Opinions on his Works.-Poli, and the Banditti._Contributions to "London Magazine."-Death of his Father.-Visit to England.-Return to 
Rome.-Thoughts on Art, and on Painters.-Reputation as a Landscape Painter.-Death of his Mother.-Venetian Art.-Titian and Claude.-MIness in Naples.-Lessing.-Rev. Hugh Rose.Isadas.-Pagan Art.-Elected Associate of Royal Academy.-"Pilgrims in Sight of Rome."_- Byron's Dream."_-"Haidee.” . 92

\section{CHAPTER T.}

Visit to England.-Reception at Royal Academy.-Bruges.-Antwerp and Rubens. - The Hagne and Rembrandt._Cologne and Meister Stephan.-Reflections from Ehrerbreitstein.-Frankfort.-Leipsic. -Berlin.-German Society.-Dr. Waagen.-Dresden and Correggio.-Munich and Cornelius.--Verona, Mantua and Giulio Romano.-Venice.-Venetian Art and Architecture.-Florence and Fra Angelico.-Rome.-Turner.-Rev. Hugh Rose.-Election as R.A.-Leaves Rome.-Copies pictures at Venice.-The Country of Giorgione, Bassano, and Titian.-Settles in London. . . . . . 11

\section{CHAPTER VI.}

Principal Works. - Changes in patronage of Art.-Society, and thonghts upon it.-Schemes for promotion of Art.-The Lawrence Drawings. -The National Gallery.-Fitzwilliam Museum.-Life of Raphael. -Göthe's Theory of Colours.-Kugler's Italian Painters.-Conversation.-Sydney Smith.-Macaulay.-Nassau Senior.-MIrs. Jameson.-Mr. and Mrs. Grote.-Earl of Essex.-Sir Robert Peel.Cornelius.-Fine Arts Commission.-Appointment as Secretary to Fine Arts Commission. . . . . . . . . . . 14

\section{CHAPTER VII.}

First Meeting of Commission, March, 1842.-The Prince Consort.Exhibitions in Westminster Hall.-Arduous labours.-Division of time.-Sources of happiness.-Fête at Campden Hill.-The Summer House.-Her Majesty.-Visit to Drayton-Characteristics of Sir 
Robert Peel.-Death of his brother William.-“Materials."Letter from Mr. Leslie, R.A.--Elected President of Royal Academy.-Commission of 1851.-Prince Consort at Academy Dinner. -Director of National Gallery.-Illness.-Death . . . . . 17

LIST OF WORKS EXECUTED BY SIR C. L. EASTLAKE . 193

CONTRIBUTIONS TO THE LITERATURE OF THE FINE ARTS.

"HOW TO OBSERVE."-Chapter I. . . . . . . . . 199

" $\quad$ Chapter II. . . . . . . . 210

DIFFERENCE BETWEEN LANGUAGE AND ART.-THE BEAUTIFUL AND THE SUBLIME.-REPRESENTATIONS OF

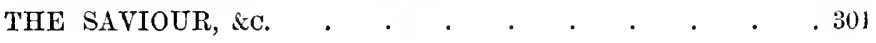

DISCOURSE ON THE CHARACTERISTIC DIFFERENCES BETWEEN THE FORMIATIVE ARTS AND DESCRIPTIVE POETRY . . . . . . . . . . . 331 



\title{
MEMOIR
}

\author{
(O)
}

\section{SIR CHARLES LOCK EASTLAKE.}

\section{('HAPTER I.}

Analysis of character.-Birth, family, and edncation.--Plympton Grammar Sehool.-The Charter House.-Haydon.-Resolntion to be an historical painter.-First studies at Royal Acarlemy.--Sir Charles Bell.--MIr. Jeremiah Harman.--First commission for a picture.--Turner. History of John Eastakc.

Ix perusing the life of a Painter the renter is reminded at the outset that it is the man rather than the artist who invites attention. The amals of a Painter's worlis may be comprised within a brief catalogne of subjects, dates, and patrons; - the critical estimate of them, as on most works of art which convey their own interpretation, may be given in comparatively few words; - the events in the life of a laborions and successful painter are generally scanty. It follows, therefore, that if the mind which underlies the art should not have found expression in forms of more general interest, there remain but slender materials for a memoir.

Nor is it safe to infer that a Painter's mind may in great measure be read throngh his works;- - his mode of viewing Nature, his feeling for Art are seen in them; but the force or the refinement which they display are not invariably recognisable in the individual who gave them birth. It is a mistake to expect that we shall find the man always in har- 
mony with his creations; and this will be found to hold true in opposite senses. For if the powers of certain minds would seem to have been adapted by Nature to flow through the channel of the arts, and through that only,-leaving sometimes the rest of the man apparently the drier-there are, on the other hand, instances where the force of character and energy of will which assisted the painter's career would have ensured excellence in any path of intelligence;-where the art, howerer attractive, presents but a portion of its author's mind, and where a true estimate of the man can only be gathered from evidence beyond that which his works can supply.

Sir Charles Eastlalie, it may be asserted, was one of those painters whose art, however in unison with his mind, by no means conveys a just measure of it. He possessed a combination of qualities adequate to conduct him to success not only in pursuits congenial to the culture of art, but in those commonly held to be alien from it. He may be said to have been singularly endowed in this respect, that his strength lay in the union of two natures, rarely compatible; - the accurate and judicial mind with the refined and ardent rsthetic sense. Whilst remarkable from early youth for the eager pursuit of learning, for indomitable resolution, acute judgment, and fine memory, he deroted all these faculties to the enthusiastic cultivation of a pencil the chief characteristics of which are delicacy of taste and refinement of feeling. And while in later years known for powers of organisation, capacity for business, and all that is supposed to belong to practical common sense, he combined these habits with the most sensitive type of the artist nature.

Yet, with all this enmmeration of qualities,-rather instruments for good than good in themselves-small justice would be done to the object of this memoir unless the moral keynote to which the whole mental scale harmoniously responded were also giren. It was here that the real 
strength lay, for the deepest and sincerest moral convictions ever went hand in hand with his keenest intellectual purposes - giving them fresh meaning and dignity. While, happily, the analytical character of his mind never tempted him to doubts or speculations on those mysteries which appeal to a higher sense, he helil all that came within what he felt to be the legitimate sphere of human reason with no weak or credulous grasp. In all conclusions and definitions which he arrived at, and in the processes which led to them, his mind was eminently clear;-so clear indeed that he could well afford to be temperate in maintaining them. And thus in the discussion of questions, whether of passing or permanent interest, he possessed the double advantage of firmness of position and moderation of manner. 'This systematic clearness of mental habit-the fiuit as much of conscientious feeling as of intellect-lent itself equally to the transactions of every day life and to the patient search after those laws which govern even the perplexing problems of art. These problems are of so subtle a nature that if the writings of Sir Charles Eastlake on the deeper philosophy of art present difficulties to the unpractised reader, the cause may be ascribed rather to the nature of the subjects treated than to any defect in his method. For he was truly an expositor with whom few came even in passing contact without acknowledging a master artist in the arrangement of thoughts, and in quiet lucidity of expression. This was an impression which I venture to say he rarely failed to create, though in other respects his modesty and reserve, a certain anxiety of temperament, and a constant delicacy of health, tended rather to conceal than to display the range and abundance of his gifts.

The following brief memoir has been chiefly extracted from a collection of letter's addressed to his parents and brothers, beginning from an early date. Little more has been left to me than the privilege of selecting such as tend 
to show the gradual development of a remarkable mind, as well as the sure success which attends umrelaxing industry.

Charles I ock Eastlake-so named after his mother's stepfather, the Rev. Charles Lock-was born at Plymouth, the 17th Norember, 1793. His father was Mr. George Eastlake, Armiralty Law Agent* in that town. George Eastlake was a man of energy and wit, and of liberal education, and played an important part in the improvement of his native city. The mother of Charles Eastlake was Mary Pierce, danghter of Samuel Pierce, of an old family settled for several generations in Exeter. She was a woman of very refined and gentle nature. Her son derived his features and expression from her. Charles was the youngest of four sons; the others being William, born in 1779, George, in 1785, and John, in 1791. All were men of more than average ability, especially $\mathbf{J}$ ohn, of whom more will be said. The standard both of education and instruction was high in this family. Industry, application, and self-rlenial were strenuously tanght and practised among them; and the habitual tone in conversation and letters between father, sons, and brothers, was scholarlike, cultivated, and accurate in thought and in expression. Charles was well qualified by nature to maintain the family standard; and a strong stimulus was early applied to the conscientious, painstaking, and highly ambitious disposition of the young boy, for his eldest brother William, fourteen years older than himself, and also a scholar and student of no mean class, took an almost fatherly interest and pride in his advancement. His early studies were conducted at the Grammar School at Plymouth, under the Rev. Mr. Bidlake. Charles also was one of the first pupils of Prout, the wellknown water-colour artist, a native of Plymouth. $\mathrm{He}$

* This office has been for three generations in the Eastlake family, and is now worthily held by Mr. William Eastlake, eldest surviving nephew of Sir Charles. 
copied Prout's drawings, and, with other pupils, used to accompany Prout into the country and draw from nature. He also had lessons in French from a Monsieur Lelong; and a schoolfellow and fellow-townsman still remembers the parts which Cliarles Eastlake and he took in the acting of a French play, called "Julius Casar"-Charles playing Brutus-which was given in the Old Assembly Rooms of Plymouth. Charles was then about ten year's of age. 'This laid the foundation for the pure and perfectly pronounced French spoken by him in later times; and both the drawing and French lessons show the liberal standard of education laid out for him by his father. He was first intended, and I believe by his own choice, for the profession of an architect, and there is no donbt that the rarious acquirements requisite for a thorough knowledge of architecture held out peculiar attractions for him. At the same time, and in corroboration of the summary I have endearomed to give of the many and varied gifts with which he was endowed by nature, I may observe here that the love of drawing does not seem, as in most painter's, to have taken the lead of other pursuits in his youth. He could indeed hardly pursue it more ardently than he did all he undertook. What may be said to have been more strictly his voluntary delight and recreation was the art of Poetry. He committed much to memory, and composed many a rhyme. Of these early effusions a few survive which there is no occasion to notice further than as proofs of remarkable refinement of thought and propriety of imagery in one so young. He was also an enthusiast for music, had an ear of singular correctness, and was not deroid of nechanical power on more than one instrument. At the same time, though remembered as "always a quiet and a studious boy", " and determined to do well whaterer he undertook," he partook ardently of boy's sports, was a skilful bird's-nester and a "dab at marbles." 
Mr. George Eastlake had a small country home called St. Mary's Hill, in the beantiful rillage of Ridgway, in the parish of Plympton, fire miles from Plymonth. Here, for a short time, Charles attended the old grammar school where Reynolds had studied before him. When he was fourteen rears old, his father and eldest brother decided that his abilities warranted the supposed advantage of education at a large public school, and seem to have wavered in their choice between Eton and the Charter House. Finally the Charter House was selected. The boy was becoming by this time rery impatient to distinguish himself. He writes from Plympton-where he felt he was not making sufficient progress-in May, 1808, to his ever dear and kind brother William, with an ardour not destined to eraporate with borhood:- "In your answer to my former "letter you seemed to think that I under-valued Latin and "Greek. If I did make use of any expressions that might "lead you to think so, it was only through my impatience " of pursuing my professional studies, which I am sorry to " say (though it is not my fault) have not been so hard " this last rear that I have been at Plympton as I could "wish. After all the sanguine expectations that have been "formed of me, if I should not answer them throngh want " of study, the pain I should feel would infinitely exceed " the disappointment of my friends. I know not whether " this fear is pusillanimous or not, but in my present " situation erery month of retarded improrement seems "a year." These few words are an indication of that ferrent eagerness for knowledge which inspired him, and which subsequently, when entirely his own master, was pursued too ardently for his physical powers.

In the antumn of that year, 1808, Charles Eastlake was placed at the Charter House under the roof of the Rer. Mr. Watkinson-the Head-Master at that time being Dr. Raine. On the 15th October, 1808, the boy writes to his mother 
his first letter from the Charter House:- "The regu"lations of the place, all of which I am hardly yet " acquainted with, are for the most part rery disagreeable. "Mr. Watkinson, withont any examination, more than " asking me what books I had learnt, \&c., put me in the " ' Shell,' but I find that the boys from the 'Shell' down" wards are fags to the upper boys, and I am unfortunately " included in the number. So disagreeable, indeed, is my "position at present that I have written to William" (his brother was then in London) "to speak to Mr. Watkinson " to put me into the fourth form, where they are exempt "from fagging; for though the work is much harder there, " yet I wonld rather fag day and night at my books than be " constantly employed for the whims of boys, prechiding " the possibility of studying, for this is really the case. At " times I look forward to melancholy prospects, but I " daresay I shall soon be comfortable. The thing is, I am " now undergoing a change from what you called the "Mathematician and Philosopher to the school-boy.

"I have a very good bed, and find everything comfortable " except the unprivacy of the place we sit in. There are "about sixty of us in a little room abont 16 feet by 9 . ". . . The boys are so thick abont me that I cover "over every line as I write, so I suppose I have made a " pretty scrawl." . . . The young gentleman, however, appear's to have had no lack of liberty and to have turned it to abundant use. In this same letter he says :- "I have seen the Panorama of St. Petersburg, and "went to the Opera House. It was the only thing in "London which exceeded my expectations, except St. " Paul's. The streets, \&c., were very nearly just what I " thought they would be. The first day I came here I "walked to St. Paul's and Cheapside by myself, and the " next morning went from the Gloucester Coffee House " down to Westminster, over the bridge, from thence to the 
" Obelisk, then home over Blackfriars, and did it in less " than an hour. 'Tell $\mathrm{Mr}$. Jope I have been through Dyot "Street" (a place noted for thieves) "after night, but it "was by accident and with Willian. I also know all " the intricacies of the Seven Dials, and in short am quite * " a cockney. Give my love to Joln, and tell him he can't " clow over me any more about his lnowledge of town " life, and that everything he has told me is exaggerated " beyond measure."

I purposely give extracts from these youthful letters-for" no boy was ever more truly fatler of the subsequent man. Affectionate as was the spirit of his home, Charles was no petted child. He had enjoyed no indulgence under the paternal roof, except the love of his mother, and the facilities for his unlimited ardour for study. He had run the educating gauntlet of eller brothers' persecutions-loving and excellent as they were-himself more refined and timid, but also as manly as any of them. There was, as I have endeavoured to show, a curious cross between the resolute will, inflexible principles, and contempt for labour, with the sensitive mind and delicate organisation; and it is in the harmony of these opposing forces that the true key to the comprehension of his character is to be found.

The next letter to his mother is equally characteristic.

"Oct. 24, 1808.-Next Sunday I am asked with William " to dine at Mr. Jones', where we are to meet Friend the "Astronomer. (You recollect 'Friend's Evening Amuse" ments.') 'Though you may think I am very comfortable " in going out so often, yet I am one who camnot enjoy the "present for the remembrance of the future. I allude to "when William returns home. Howerer, can I succeed " in getting into the fourth form, I shall be comfortable " enough, but my present situation is most painful, as "I am in the agonies of suspense. . . . We have "a librury here, to which I have subscribed a guinea. 
"There are a great many valuable books; among them is “the 'Encyclopredia Britumica,' 'Carey's Maps,' Sc. "These two works, however, I have not the privilege of "perusing, being an under boy. . . . We may always "go out with a note of invitation; and, while an under boy, "a man always attends me to the door of the house I "go to. T'his gives rise to immumerable impositions, which " the boys call ' fudging out.' They wite a note to them"selves, get a day-scholar to put it in the post, and then, "when the man goes with them, call at a friend's house, and "walk about the town the rest of the day."

'The Charter House episode was very short. Instead of getting into the fourth form, the boy's determination and his father's liberal sympathy soon removed him from school altogether.

Haydon the painter was a fellow-townsman of Charles Eastlake. He was nearly eight years older, and just then in the first flush of temporary success. The latent feeling for art, in all its forms, in the roung mind needed less eloquence than Haydon possessed to call it into life. A sense of the power and charm of pictorial art as combining accuracy of hand and eye, with refmement of taste and abundant erudition, burst at once upon him, and impetuously, and almost impatiently, declared itself in a resolution to be an historical painter. But this cluster of attractions may be better described in his own mode of reasoning - for he reasoned on all he did. (June, 1809). "I was always particularly attached to "Poetry, and latterly used to regret that it was not " more substantial, so that I could make a profession " of it. But I have now entered upon that which, as it "were, embodies Poetry, and can safely say that in Paint"ing not only the feeling of the Poet is required, but " a mind that can submit to be fettered by the most " unalterable rules of the deepest theories, though still 
" joined with feeling, and at the same time combined with " the hardest mechanical labour." His letter to his father, announcing the determination he had formed, shows a union of cool reasoning and intense ardonr very remarkable, howerer boyishly expressed in some respects, in a lad just turned fifteen. He had found the real purpose of his life, and pleaded for it with all the persistence compatible with unwarering filial piety. And in perusing this and following letters it must be remembered that while Charles Eastlake - boy and man - had a sense of duty towards parents and superiors which is only too rare, yet the peculiarity of his home education had practised and developed in him a power of argument which virtually put its possessor on a temporary equality with all towards whom it was used.

"Gloucester Street [his brother William's lodgings],

"Mr near Father, 21 Dec., 1808.

"You will at first be doubtless greatly surprised " at the contents of this letter, but I hope that you will " both peruse it and judge of it seriously.

"In the first place, it is necessary to inform you that my "profession is malterably fixed-it is that of an historical " Painter. My enthusiastic propensity for it, my ardent " desire to begin my studies, and my future reputation as " a Painter, require that I should leave the Charter House " immediately. Though as to leaving it literally imme" diately, I myself do not wish it, as (were I to come away " this vacation) I should have a quarter to pay and receive " no benefit from it in the classical way, but at the end of "these holidays I would give notice of quitting at Easter. "To this there are, I know, objections. First, that I "should sacrifice all improvement in the classics-that "I should lose the chance of forming connections that "would be afterwards serviceable to me in life-that I " should not have been there long enough to derive any 
" advantage from the noise and bustle of a public school" and lastly, that I should have paid eight guineas entrance "for so short a time. I answer thus. The improvement I " have made in the classics at the Charter House this last "quarter has certainly been something, but the improve" ment I have made under Mr. Jones now in three days, "for an hour" a day, is as much as I should there make in " three weeks, and William is satisfied by Mr. Jones' argu" ments that I should leam twice as much by myself as "I should at such a school. As to comnections, if there "are any worth forming, and there are very few if any, it "wonld be among the Gown boys, and they live in a "separate house; so that it is next to impossible to be " intimate with them.

"As to gaining a linowledge of the world from the noise " and bustle of a public school, the Academy is the place "for that, and Haydon, in his impetuous way, has offered " to introduce me there directly,-but all in good time. "Then as to the last objection" (the eight guineas entrance) "I am under no apprehension that my clear father will "think that the least obstacle to my quitting the school, " and the object I am in pursuit of would be more than " a sufficient excuse to the masters for my so doing.

"William thinks I should first come down and study the " sciences at Plymouth; but whatever are my studies in "addition to painting, London (to use William's own " words) is the field for action.

"Under these considerations I shonld hope my dear "Father will not hesitate in making me happy. George " has only told you the tricks, William will tell you the "vices of the school I am at; and if he does not regret " sending me there, he confesses that it will be a miracle if "during my stay I get into no scrapes. I am persuaded " you think me proof against the rarious depravities I " allude to, but to use rour own memorable expression, 
“" Gutta cavat lapidem, non vi, sed sape cadendo.' The "vices I daily witness are more than Guttas, and perhaps "I am not equal to a 'Lapidem." * But why should I " endeavour to influence your mind thus? I have one "argument stronger than any, which is that the happiness " of your youngest son (whom I am persuaded you love) is " called in question. I am sure you will not check the " ardour of my mind-indeed, I never knew what it was to " like a profession till now.

"I need only add that William acquiesces in your " decision, whatever it may be, or", in other words, that I "only wait for your answer to ratify and confirm my fate. "Recollect, my dear Father, that my happiness or misery " now depends upon you. . . . . I wish I could think " on anything stronger to convey to your mind an idea of " the anguish (for it is more than solicitude) I feel while " expecting your answer. But when I consider your kind" ness I fondly anticipate the result. Above all I must " remind you that this is not the effect of the mere " ebullitions of a fervent imagination-it is an irresistible " propensity which will remain (if not untimely nipt) for ever. "And when I cease to be a painter I almost cease to live.

"Your affectionate and dutiful son,

$$
\text { "C. Eastlate." }
$$

'The father formed a just measure of his son's character, and took him, at whatever personal sacrifice, from the Charter House forthwith, placing him under Haydon's care. By Jamury, 1809, the young aspirant was established at 3, Broad Street, -where Haydon had formerly lodged. He writes to his father at that date:- "I shall make it the " business of my life to attend strictly to the kind admoni-

* These remarks, penned more than sixty years ago, will be taken for what they are worth. They are only retained as eharacteristic of the young writer. 
"tions contained in your letter. I shall set apart two " hours every day for the exclusive study of the classies. "Mr. Jones says that if I give up an hour every day, that in " a year I shall be able to read any Greek anthor. What I " principally want is to be able to read Homer without a " Lexicon, and I shall set about it forthwith. But all my" " studies must be subservient to the grand one of Painting. "Fuseli, for instance, is an excellent classical scholar, and " has published two editions of Homer, but he knows " nothing of the mechanical part of the art. . . . " Haydon is rery kind to me indeed. He mentions me "always as his 'Fellow-in-arms and comrade of the War.' ". . . . He has taken me twice to Lord Elgin's, and " introdnced me there to Mr. Hamilton, a friend of Lord "Elgin's, who has been at Athens. I have seen and "toucher those rery friezes which I admired so much in " Nicholson's 'Architecture;' and those little figures which "are actually half as large as life are the trimmp of "Sculpture, though their beanties conld never have been "seen from the gromd, and they were intended merely as "ornaments to the cornice." On February 17th, he reports having obtained from Mr. Northcote a ticket for Mr. Carlisle's lectures on anatomy (at the Royal Academy) -that he was drawing from the Hercules to qualify for admission as probationer at the Academy, and that he was impatient "to attend Bell's" (Sir Charles Bell's anatomical School). "I shall, I smppose, finish the theory of anatomy "this eveming, so that I an nearly prepared for the "practice. If you were to put Painting, Sculpture, and "Architecture ont of the question, I think I would rather " be a Surgeon than anything else."

At this time, 24th February, 1809, at midnight, Drury Jane Theatre took fire and was burnt down. Charles Fastlake spent the night in the street, climbed the railing into the portico of Inigo Jones' Church, "but was forcerl to 
" retire behind the pillars every minute, the heat was so "excessive," and writes home a letter full of little sketches of the scene, which he also commemorated by a poem.

On March 19th he announces to his brother William that he had gained admission into the antique School of the Royal Academy by a drawing of the back view of the Discobolus. "Haydon gave me a very handsome letter of intro"duction to Fuseli, who was very kind, and said he should "take pleasure in giving me any instruction while in the "Academy. Since I have been there I have done two " heads, and the front view of the Discobolus, by which $I$ " might hare got my ticket, and become a regular Student, " but as there was a little risk, and I am in no hurry, "I chose rather to wait until after the vacation. The "Academy closed yesterday and will not open again till "July. On Friday night, Monro, Dr. Monro's son-a " great friend of mine-proposed to me to have a model " in the racation so many times per week to draw from. "This spreading about, sixteen students agreed to sub" scribe, and we all left the Academy and repaired to the "Hall ; and after' a great deal of speechifying, clapping, \&c., "Monro and another were appointed to find ont some con"venient room for the students and model to sit in and " draw. . . . . We shall meet again and nominate a Presi"dent, Treasurer, and Secretary. It will not cost more " than two shillings a week. We shall draw every night from " 6 to 8 , or from 5 to 7 . My time has been well employed " at the Academy. I rise early, and sometimes draw before " brealkfast, \&c., \&c., in my own rooms. At half-past 9 "I go to the Academy and draw till 5 -from 5 to 6 dine " and take a walk, and from 6 to 8 am at the Academy " again. Then, from 8 to 12, Latin, Greek, and Drawing." * We look in rain in these youthful letters for the signs

* In these early Academy days his fellow students used to banter him on his age. "Well, Sir ! are you fifteen yet?" 
of the boy, and equally in vain for that precocious coxcombry which generally takes its place. The only signs of the age are its ardour and its openness, and yet these always expressed in language beyond his years, with a keen argument, an inflexible principle, and a steady purpose. Charles's natural logical powers, as I have already obserred, had been early practised in the usual word-fencing with elder brothers. He was their pride and delightnevertheless he had lived the defensive life of a junior member. In the April of this rear, 1809, (still only 15,) a check upon his expenditure, in which he was supposed to be becoming too profuse, took place; and openness and argument (and happy the father and elder brother who have no worse confessions to hear) "as to the cause of this sudden "bankruptcy" accordingly follow. He owns first, (this letter was to his brother William, ) to laving out " a pretty large sum " in plates and casts," and then to having instituted a practice of paring his lodgings per month, instead of per week, by which so fictitious a sense of riches was created that "I " astonished my friends with another influx of plates and "casts." Then come statements of very small debts, and a confidential explanation that Haydon had told him that before finishing his first picture he owed $\$ 70$. “As I do not " wish to let my fate depend on my first picture, as he "owns he did, as to money matter's, I take this early "opportunity of mentioning the danger as soon as I " perceive it: and though it is as irksome for me to tell as "for you to be made acquainted with this evil, I am con" fident it prevents a greater-viz. : that of being involved " in debt without my father's knowledge. . . . . The "sum of all that I have been saying is that I request you " to allow me $\{8$. per month. However, should this not " meet with your approbation, I need not tell you that I am "ready to die for my profession, which I like ten times " better than ever. Had I now just left the Charter" 
" Honse my ardour would have been damped ten degrees, "whereas it is now rising (tell John) in geometrical rather" "than arithmetical proportion." He also owns to two more expenses "which I have not been able to resist, "viz. : buying Sir William Jones' Institutes of Menu, and "going to see the Panorama of Great Cairo;" and finally" he confesses to having subscribed two gnineas for a seat in Fitzroy Chapel, which was attended by Haydon and Wilkie, where two pictures by West still hang, and where at that time Sydney Smith preached.

This letter is not necessary to prove the radical difference betreen Haydon and his pupil, as much in their views of life as in the character of their art. No two men were ever more opposed in these respects. Poor Haydon made no exception to his halits in favour of the young lad, and money borrowed and never repaid soon cansed a coolness between them. At the same time it would be most mjust and ungrateful not to own that Haydon's great intellectual qualities and powers of appreciation were highly congenial and favourable to his pupil. A reference to Haydon's biography will show how often he quoted the judgment of his young pupil when dealing with the higher philosophy of art.

It may be stated here that the principles laid down by Charles Eastlake as a lad of fifteen were never departed from. That intensity of conscientionsness - that truly religions horror of defranding the labourer of his hirewhich in after years made him anxions to pay his servants their wages on the morning rather than the afternoon of the quarter day, never diminished. Howerer generous in benerolence, however profuse in all that concerned his adrance or his pleasure in art, he never owed a pound that he could not command the immediate power of paying.

During the month of April, 1809, Charles Eastlake paid the necessary premium of five pounds-which harl been in some jeopardy dnring the late embarrassments-for 
admission into Sir Charles Bell's School of Anatomy, and began to draw the bones separitely. His remark on being first introdnced to the great anatomist, and one of no contemptible weight even from the inexperienced lad, was-c " $\mathrm{He}$ " is the most gentlemanly man I ever saw."

He was now, as he tells his father, "working as hard as " my strength can reasonably allow"- -and even, it is to be feared, beyond it - for every fresh opportmity only induced corresponding extra exertion. Speaking of the approaching celebration of the Jubilee (the completion of the 50th year of George the Third's reign) he says, "If "there is an illumination I shall draw all night." He also reports that he could read Virgil without requiring the lexicon, and had made great progress towards a similar familiarity with Homer. At the same time there grew with his growth and strengthened with his strength a most just and clear discrimination of the nature and object of art; - what is oftener felt than defined by the jurenile student, and of which the outside world have rather vague notions. Brother William had got a little out of his depth in this way, and is thus satisfactorily answered by the aceurate young philosopher of fifteen. "September, 1809.-I find that there is a " misunderstanding between us with respect to my beginning " to paint, inasmuch as you think that I want to transfer my " ideas to canvas, whereas I only want to learn the mechanical " part of painiting by copving from nature. I must learn " the language of art before $\mathrm{I}$ can express ideas. This is " at once an answer to your queries; and what may tend " to enforce it not a little is that Sir Joshua Reynolds " used to think the mechanical part of painting of more " consequence to be attained than drawing itself-though " in this I mrself by no means agree with him. In the " beginning of your letter you say that the motto "Infelix " qui pauca,' Sc.," is applicable to me in general matters,

" "Infelix qui pauca sapit, spernitque doceri." 
" though you joyfully bow down to me on subjects con" nected with art; but at that rate there is no occasion for "quoting the motto at all, as art was the subject discussed. "Of the two parts of painting, the mechanical and the " intellectual, I certainly agree with yon that the latter is " the most difficult-indeed, so difficult that it cannot be " acquired (in a certain sense) at all. Mr. Charles Bell has " gone as far as it is possible in the doctrine of expression, " and that doctrine any one now can learn; but the com" binations are effected by the artist's feeling. As to " attempting to discover the cause why certain muscles of " the face are put in a certain action when a particular "feeling is excited in the mind, this is beyond human " comprehension and ever will be. I firmly believe myself " that the will is conveyed along the nerves to every limb " before it can move (except in involuntary motion); but " all these ideas are merely hypothetical, since in these " things it is impossible to discover the secrets of nature."

His determination to master the difficulties of drawing was in accordance with the thoroughness of his character, which tolerated no carelessness in the foundations of any study or structure. "Nothing is stronger than its weakest " part" was ever his favourite maxim. When he had applied himself to drawing for about six months, he sent some specimens home to his family with these observations:" My friends here all think that I have got on very well " considering the time; but $I$ have not yet got that specious, " masterly dexterity of handling the chalk which among " superficial observers passes for the greatest excellence of " the drawing, whereas it is only the ornament. If, therefore, " the drawings you have seen and will see do not answer " your expectations in this particular, it is because, to use " the words of Sir Joshua Reymolds, 'I do not prefer splendid " negligence to painful and humiliating exactness." "

In December, 1809, he obtrined admission into the Life 
Academy by a drawing of Cupid and Psyche; and in April, 1810, the silver medal at the Artelphi by one of a bas-relief. Some of his designs at this time were seen by $\mathrm{Mr}$. Jeremiah Harman, the well-known banker, whe possessed a fine collection of pictures by the old masters. This gentleman, who subsequently became his most kind and liberal friend, immediately proposed that Charles should execute a picture for him. He suggested the subject of the Man possessed with demons coming out of the tombs, but a classical subject attracted the young lad more. One, accordingly, was chosen by him from which he expected great results, and which entailed much rearling up of authorities and even buying of books. Pausanias-a quarto edition in French-Macrobius, \&c., were purchased, and his brother William appealed to, as if life and deatl hung on it, for any authorities regarding the Panathenaic festirals. The letter winds up with this practical application by the youth of sixteen: "Such a work as painting an historical " picture may be divided into two parts-the conception of " the subject, and the execution. The conception of the "subject must be assisted by all possible information "respecting it: that information is contained in books; " these books cost money. The execution of the subject is " assisted by oil, paint, and brushes; and these things also " cost money. Now comes the Q. E. D. of my proposi" tion," and a financial difficulty was stated. What was to be done with such a young reasoner? It is but fair to both parties to state that money was liberally given and carefully spent; but there was one error on the part of his family which the recipient had no difficulty in expressing in the clearest language. "Nothing disturbs plans of economy " more than irregularity in the receipt of money". I know " that I am very liberally supported both with reference to "your means and my wants; but there is a lamentable "want of economy and system in the method of affording it, 
"so that what is in itself liberal, very liberal, is rendered, "by want of management, paltry and insufficient." They failed to send him the promised sum at the stated times. Delays in remittances cansed anxiety, and led to what he terms "almost monastic privations," which meant pinching of everything but his art, and to borrowings, however small in scale. And then the logical consequences were stated; " and if I borrow I must lend."

Nevertheless, in July, 1810, he was rapidly progressing with this his first essay in oil and composition, when he discovered by further classical researches that the subject he had chosen was one not desirable in all respects to record. After much heartbreaking, therefore, at the loss of time incurred, the subject was abandoned, and that of the Raising of Jairus' daughter, by the concurrence of Mr. Harman, chosen in its stead and painteck on the same canvas.

At this time intense application and the late disappointment seem to have told upon his health, or rather to have inspired his affectionate brother William with anxiety which showed itself in urgency for his return for a time to the paternal mansion. The occasion would not be worth mentioning except as eliciting one of those ebullitions of ardour of expression and intensity of purpose, when engaged on what he felt to be duty as well as pleasure, which distinguished the lad.-" $23 r d$ April, 1811. . . . . . . . "I consulted a surgeon (and a physician, an intimate "friend of Mrr. Bell's) last November about the blood"spitting, and he said it came from the throat, and that " there was not the least occasion for me to be alarmed. . . " Now, I most solemmly declare, I am as well as I ever have "been. Besides, if it be allowed that health accompanies " happiness, I am now the happiest of mortals, and any" where else, and doing anything else, I should be the most " miserable. I have but just begun my picture, and how " ridiculous it would look if I were to desert my post before 
"I had given any proof to others of ability, and when even " my own expectations are fluctuating between hopes and " fears. It would perhaps be different if my picture were in " a very forward state, but I see 110 end to it yet. I look at " its completion with a sort of awe-the gulf has yet to be " passed, and can I stand loitering on the brink till my " powers are dissipated by delay? My dear brother writes " under the influence of one motive only, that of finternal " solicitude; but there are other things to be considered. "He should remember that I am not my own master. " What would Mr. Harman say if, on calling to see how "I get on, he was to be informed that instead of attending "to his commission I was gone into the country to enjoy " the summer months. It would ill become me (having "been so fortunate as to have a picture bespoke) to trifle " with my success, and to set at naught an engagement " which any other person would think it the business of " his life to fulfil. Again, if I have any regard for my " reputation, or any respect for my conscience, shall I not, " do I not, burn to make up for time lost, irrevocably lost? "The agony occasioned by this reflection is only relieved "by actual employment on what has been so long delayed. " The contemplation of the future being consequently sad" dened by the remembrance of the past, all that remains " is to make this future, present, knowing that nothing is " denied to well-directed industry. Why then would you " seek to delay my approach to that happiness which has " been so long a stranger to me? All these arguments will " be, however, unnecessary ; for as you only wish me to come " down because you think I am unwell, I most solemnly " assure you again that I am not unwell. This, I hope, will " be alone considered a knock-me-down argument. Should, " however, my plighted honour" and all the arguments I have " used be insufficient to convince you of the truth, I now "proceed to declare by all that is sacred that I will not 
" come down-no-not if you were to come up with all the " town of Plymonth in your rear, not if you refuse to send " me one farthing more during your life. As your letter is "peremptory, it is necessary mine should be so too. I am " by no means insensible to your kindness (of which your " letter is a sufficient proof), and I hope one day to repay it " all substantially, but 'your' zeal becomes importunate' . . . "P.S. I am sorry postage has cost you so much in this " affair; however, here there is now an end to it. I think a " journey to town would do you good, and I should be truly " glad to see you, but you may be sure you will return " without me."

In the composition of Jairus' daughter the young painter threw himself, as he had done before with his attempted classical subject, into the lore and archrology of the period represented. Costumes were ascertained with all the accuracy authority could supply, and accessories were matters of the intensest anxiety and research. There was the lustral basin of a reddish marble with a bunch of myrtle; the book of the law, - a roll of parchment. There was the rase containing flower's, "because among the Jews "a corpse was washed with water in which roses and "camomile had been boiled." (He had extracted the funeral rites of the Jews from a Latin work in 34 volumes at the Royal Institution.) There were the cedar columns twisted round with palm leaves, and the burning candles in curious candlesticks. In all this was seen the natural propensity of a scholar, not sufficiently versed in his adopted art to know how comparatively unimportant is such historical accuracy. And of course such portions of the picture were more successful in execution than the figures themselves, though these also show the germ of the refinement and expression which became his characteristics-while in colour and breadth of light there is already more than a promise.

Not that the anxious finish of detail at this time-natural 
to the conscientious painter, and always the right end at which to start in the career of art-implied any absence of the just estimate of the qualities to be desired. On the contrary, far from being misled by any enthusiasm for the wrong thing, there is a most striking proof, in these early letters, of admiration for a painter whose art, to this day, is a Shibboleth to the uneducated or half educated. At seventeen years of age (July, 1811,) he writes to his father, introducing to lis notice Turner the painter, who was on his way to Plymouth :- " What he wants is to go on " board some large ship, and I daresay George will be rery " happy to take him on board the Salvadore, and perhaps " into the Dockyard, \&c. He is the first landscape painter " now in the world, and before he dies will perhaps be the "greatest the world ever" produced. I hope all at Plymouth "will be attentive to him, as it is really an honour to be " acquainted with him. He is much higher in his branch "of the art than West and Fuseli are in theirs. I say all "this because you may never have heard of him-if you " have it is unnecessary." Turner afterwards became one of Sir Charles' sincere friends.

It may be noticed that there is an absence in these letters of a recital of the youthful difficulties and dawning ideas in the path of art. So far as this exists it arose from the nature of the mind,-always somewhat deficient in hopeto shrink from communicating equally those ardours and despairs,-especially the former,-which mark the artist's progress. There are hearts which do not speak by the mouth from their abundance. It was thus, in great measure, with Charles Eastlake as regarded his profession. He looked, as he has said, on the completion of a picture "with a sort of awe;" and this was the case not only with his first work but with every work he executed. In the course of this memoir, however, no want of communicativeness will be found as to his growing experience. 
During the progress of this first picture, on which so much ardent enthusiasm was spent, Charles had been joined in London by his brother John-two years older than himself-(born 1791.) This brother was so remarkable in power and gifts that the unknown sister-in-law, writing almost sixty year's after his death, will be excused for inserting his too short biography here. John received his education, first at the Exeter Grammar School, and afterward at the Reading School, under Dr. Valpy. He was equally as ardent as Charles in the study of the classics, and also showed extraordinary aptitude for mathematics, which he studied under Mr. Harvey, the well-known mathematician at Plymouth. He was still more enthusiastic in expression and equally determined in purpose, was of a stronger physical frame, and, lacking the love of art, of a less complex character than his younger brother. A portrait of him by Charles, painted in 1811, shows a young man of broad forehead, black brows, and strong jaw, and with the expression of a resolution which one would not willingly have contested. But his character had its tender side, and the affection for and faith in his brother Charles, which runs through his letters, shows a fondness oftener found in a sister than in a brother.

John's character displayed itself strongly in his early years. He is still remembered for his nobleness, courage, and indifference to pain. An old school-fellow, Dr. Cookworthy of Plymouth,* has given me the following anecdote of him. "On the night of a 5th of November, when "Exeter was more hostile to Popery than it is said to be " now, the boys of the Grammar School had a grand flare"up in the school yard with skyrockets and fireworks of "various kinds; and after the head master, Mrr. Bartholo" mew, had retired, a bonfire was made with the rocket "stickss and some old rabbit-hutches. Whilst dancing round

* Dead, since this was penned! 
" the tiny blaze the bell for prayers was unheeded by the " boys, and Mr. Bartholomew, greatly displeased, inquired "with whom the fire had originated? Of course all were "silent, and, on his saying if he were not told he would "flog the whole school, John Eastlake stepped out and " said, 'I began it.' Mr. Bartholomew then insisted on " his naming another", threatening to flog him severely if he " did not tell. The boys had been drawn up for this in"terrogation in two long lines facing each other. My place "was immediately opposite to John Eastlake, and I shall " never forget his prompt and firm 'sever.' He was " accordingly punished, and cared no more for it than if " the rod had descended on the bench."

John was intended for the Bar, and had begun the study of law in his father's office at Plymouth. His letter's at the time show that he threw himself with ardour in to the routine preparation for that profession; indulging, by way of relaxation, in the study of Geometry and Algebra. Why he abandoned the course for which he had been destined does not appear; such, however, was the case, and before he was eighteen he addressed to his elder brother an appeal, which, for ardour, resolution, and dutiful feeling, may be placed by that of Charles', already given, to his father. The brother William, always a sufferer from asthma, was then at Teignmouth for his health. John writes to him from Plymoutl, May 29, 1809 :- "My dear "William,-This sudden and unexpected application to you " upon a subject, I may say, almost entirely novel, will pro" bably be construed to be the unwarranted lucubrations of " a mind destitute of experience, or "the hasty ebullitions of " ' a fervent imagination.' But I must entreat your serious "attention to the object of it, inasmuch as I consider it " (without any possible imputation of egotism) as materially " affecting my future situation in life and the commonwealth " of our family. 
"My object then is this. That should you see any " impropriety in my enthusiasm to follow the profession of " a merchant, you will not hesitate to communicate your" " objections, that I may check the progress of my ardour " while it is yet in my power to do so; nor suffer it to take " root in my heart, from whence no persuasion, however " enticing, no arguments, however clear, nor threats, how" ever menacing, could possibly eradicate it.

"T'o you then I appeal, as a father in a brother, to "decide tine fate of this new enterprize. It is useless " for me to say more at present without knowing whether "you approve of the principle of the Bill. I shall only "add that this is the first step I have taken in the " business, not having communicated it to my father. "Should you be tolerably well when this arrives, I hope "you will answer it as soon as convenient, and free me " from my present suspense."

William's answer, which has been preserved, is wise and kind, and admirably adapted to meet the "aspiring mind." He explains that Credit is indispensable in commerce, but that "Credit in the commercial world applies more to the " circumstance of property (uncle responsibility) than to that " of probity. In other professions, lnowledge and integrity " are the stock in trade upon which a man may build up " a fortune. In commerce credit is the sine quâ non." But John's wishes were not discouraged, though a year's interval took place, well filled up with ardent study, and with the acquirement of modern languages, especially French, Portuguese, and Spanish. Finally, in the summer of 1810 , Charles, then the lad of sixteen, thus writes to John, then the lad of eighteen, regarding a Mr. Hullet, a merchant whose house John ultimately entered. "He has " the highest opinion of your abilities, but says that the " modern languages will not be of such importance as "Commercial Arithmetic, Book-keeping, Accounts, \&c. 
"He hopes that it will not be long before your talents " have full scope, but that before you have acquired ex"perience ererything will be worth nothing. All there"fore which he expects you to begin with are a docile "disposition, activity of mind and body, and obedience. "..... When you pack up your clothes, instead of " shavings or paper, use rags, which mother will give you, " as I am very much in want of some to clean palette, "brushes, \&c."

In the summer of 1810 John came to London and entered the home of $\mathrm{Mr}$. Hullet of Austin Friars. Within a rery short time his energy and abilities were fully recognised, for, in addition to being book-keeper, cash keeper, discount manager, Spanish correspondent ("and French and Portuguese ditto when required") he became Mr. Hullet's private and law secretary, transacting the most confidential and intricate business before and after office hours, and evidently filling a place for which no one else was fitted.

The two young brothers did not live together; John's lodgings were in Old Bethlem, and Charles kept necessarily in the region of studios. Each respected the lifepurpose of the other too much to tempt to idleness; but they often dined together at chop-houses, or sometimes with kind friends at Stockwell and elsewhere. All the anxieties and ambition of their ardent minds were then freely exchanged, and it must be owned that their good father and brother can have had no easy task in the perusal and answering of the letter's which the combined young forces poured upon them. As for resisting them, that was in the long run impossible. Notice would be given of an impending " date obolum;" and then arguments were plied, fast and furious, upon the paternal and fraternal hearts at Plymouth, supported by such a host of quotations in Greek, Latin, and English-Shakspeare and Bacon 
being the favourite native authors-and all mrged in language of so much acnteness and wit, as were well worth the price they cost. For all common purposes of life,- costly as those days were-the supplies were sufficient, but each of the youths had his special expenses comnected with his special dawning career; and while they would sometimes dine for eightpence-halfpenny a-piece they were gradmally and respectively collecting libraries of no contemptible order or size; and in Charles's case a large number of engravings from the old master's were added. John, as the elder, pleaded chiefly for Charles, proposing to give up a portion of his allowance in favou" of his brother "for the purpose of his "advancement in his divine an't" (the good father must have smiled at the proposal), and adding, "Take Charles "all in all, and you will find that none of your other sons " has similar merit."

And there is beantiful evidence of the part the good brother William (that "father in a brother") ever played : Now the monitor" and now the friend; in turn attacked by the ardent comple, and in turn subdning them. "I have " heard you say," writes John, " that if I or Charles turned " ont bad it would break your heart." And again, after a little epistoliry sparring, "There shall be no excuse on " nyy part for any disagreement between us-on your's " there cannot be, for it is impossible for any one but of " the most malicions disposition to be at variance with " you more than a quarter of an hour."

Happy the parent or elder brother who have no extravagance to check but such as is described here, and in knowing that every failing leaned to virtue's side. In August, 1812, Charles's clear and fair mind perceived the justice of the occasional home remonstrances, and, then eighteen, he thus writes to his father-" It would be wasting time to "attempt to defend these proceedings, though I could give 
"a good account, if necessary, for the aplarent extrara"gance. It is evident from the above that I have spent " at different times what amounts to a large sum, and I " have only to inform you as to the manner in which this " has been laid out, and to show that it has been applied, " without a single exception, to the furtherance of my art " and intellectual improvement. I do not mean to urge " that the mode of the expenditure lessens the extrava"gance. I allow that I have been extravagant. I have "been too fond of considering myself" an intellectual " desperado-and, as such, too much in the habit of "thinking the acquisition of that lawful which the caprice " of the moment may have deemed necessary to rouse " emulation. I have, howerer, not practised this syrstem to " the extent of some of my acquaintances. I contend, too, " that this species of extraragance is pardonable, inasmuch " as it arises less from want of principle than want of care. " The art of taking care of money is not to be learnt in a " day, and anything in the way of advice and example which "I have here received or witnessed has been in direct op" position to true judgment, and calculated to inflame the " imagination of a painter aged fifteen-sixteen. If I had " had the frequent personal advice of my dear father and "brother, and if I had been always as ready to profit " by their experience as I am now, I should perhaps " have been spared the umpleasantness of acquainting " them so frequently with my own unconscious extrava" gance."

Charles Eastlake was enthusiastic in his admiration of the beauties of Greek architecture, the principles of which he thoroughly mastered. 'That this taste was greatly nourished by his classic predilections and associations is a fact which needs no comment. As a specimen of the ardour with which the sight of the remains of antiquity fired him, I gire a few extracts from a letter, written in 
1812, to his brother William. The opening reference is to a previous communication.

"Dear Willian, - I sent you a letter by Prout a few days " since, for the contents of which some apology is neces"sary. The fact is, that in bending his mind to different " parts of his work, a painter is influenced by a variety of " feelings, or sets of ideas. These ideas are excited in " him by-no matter what; but the worst of it is, that he "fancies the same causes will produce the same effects (i.e. " excite the same ideas) in others. The nonsense which I " sent you was capable of working me up to a piteh for " painting, but you see it (not having the associations which "I amex to it) in its native absurdity. It was neverthe"less paying you a sort of compliment to suppose that "by a certain intelligence of your own you conld enter " into my views, and catch a spark of that enthusiasm "which was excited even by such flinty materials in " me.

" The feelings which actuate a Painter are regnlated by " the nature of his employment; at present, having just "finished the architectural part of my picture, which is "Roman, I am musing in idea among the ruins of the "Campo Taccino, or wandering in imagination along the " banks of the Tiber. About a week ago I had a very " imperfect idea of Rome. I can now tell the situation of " the principal buildings, by whom they were erected, the "inscriptions on them, their comection with ancient " history, \&c. This of itself is a delightful study, but it is "particularly useful to me from its close alliance with " costume, and, in short, with classic taste. . . . It is to " excite this feeling in my future works that I wish to " throw my mind back as far as possible to the bright eras " of Greece and Rome. With the former I am pretty well " acquainted throngh Pausanias and Anacharsis, and really " with regard to the places I think the present remains of 
"Rome capable of exciting still finer associations, perhaps " because it is celebrated as a modern as well as an ancient " city. I forget where I have seen the following passage :" "It was on a fine Italian erening, when the barefooted " "Franciscans were singing respers, that Gibbon, seated " "among the ruins of the Capitol, first thought of writing " ' the Decline and Fall of Rome." If this quotation does " not fire you with the same ardour that I feel, I don't " know what will

"When the theatre at Plymouth is finished, in standing " under the portico you will be able to funcy yourself in the "Temple of the Ilissian Muses, for the columns at "Plymouth are to be exactly like those at Athens. The "screen before Carlton House professes to imitate the "same proportions, but is not correct. Mr. Harman, in " his dining-room, has two columns from the Temple of the "Minerra Polias, very beautifully executed. I wish my " dear father, who takès great pleasure in buring books for " his sons, would make me a present of some work on the " antiquities of Rome, or any of the following, if they are " to be met with; 'Archi Trionfali,' by Bartoli, 'Colonna “ 'Trajana,' 'Colomna Antonina,' 'Admiranda Roman" ' ormm;' I believe all by the same Bartoli. They consist " of etchings from the antique bas-reliefs. I could now " devour Gibbon's 'Rome,' but don't send it, because it " would be an interruption at present." He adds later :"I content myself, at present, with abridging at intervals " the Roman History."

Lest, however, such rigid though enthusiastic application to the choice of his life should suggest too severe a picture, it may be added that he could occasionally indulge in a little dissipation, though even then not without a moral and a quotation. "May 12, 1812.-My dear "William,-In order to comply with your request for an

* See Life of Gibbon, prefixed to "Decline and Fall, sc." Edition 1807. 
[Ch. I.

" entertaining letter, I had resolved to dedicate last evening "to you. But going up to Gandy's* between the lights to " ask him to come and sit for something to-day, I found " him and his brother and Jago taking wine together; so, " without the least hesitation, I sat down and cracked a " bottle with them, and afterwards played cards till mid-

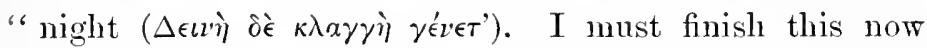
" before brealfast: although I have been a little put out of " the way by this raking, I am not at all sorry for it, for " without making a toil of a pleasure, I made a duty of a " relaxation; ' ntile dulce,'-that is, not joining business and " dissipation, but making a business of dissipation." $\mathrm{He}$ also writes to his mother: "I have been seen lately by " several Plymouth people at the Opera; and, lest I should " be thought guilty of extravagance, it will be proper to tell " you that I get order's very often, and never go without " one. I only go on Saturdays, because then the labour of " the week is orer."

Though at this time showing great vigonr of constitution, - for he mentions walking home from Gravesend with John and another, not having been in bed at all the night before, and being the least tired of the three,-yet there is no doubt that such proofs of strength tried him far too severely. He accordingly began to feel the evils of English winters, which afterwards became so trying to him. In November, 1812, he wites: "I can hardly write for the " coll. I have been thinking so long of Italy that I can " hardly fancy myself a natire of this climate, and I think I "feel the cold more severely than others. Flights of " imagination on the Capitoline Hill are exchanged for " twinges of rhemmatism in Broad Street, Carnaby Market. "However we may rival the Continent in talent during the

* Mr. Edward Gandy-late of the Armiralty-a gentleman of considerable attainments, and schoolfellow and life-long friend of Charles Eastlake. 
"summer months, I am sure that a winter in England is " not very fostering to genius. But what I most complain " of is that it is even inimical to labour, for the little fire that "a painter is able to preserve in his head seldom extends " itself to his fingers." Again, as displaying another vein of the rich nature, and one which lay too deep at the heart to come often to the surface, I quote a short passage to his mother after receipt of a kind Christmas present from her, and from his always affectionate annt, Miss Anne Pierce. "It is very seldom that I sit down at my ease to write a "letter, but I am now so overpowered by your and my "aunt's unbounded kindness, that I am determined to "devote a little time, not to express my thanks, for that "would be impossible, but merely to impress you with the "conviction that I am sensible of you" affection, and to " delight and recreate mýself for a while in an imaginary " conversation with yon. . . . Even a complaining letter "from my father is pleasant to me, I see his writing so "seldom." The real value of such letter's from a young lad must be estimated by the use he made of his time; only rare and spare minutes snatched from rest being given to such an inclulgence. He writes later to brother William: "I should as soon think of reading a novel in the middle " of the day as of writing a letter."

But to return here to the brother John. Another change, and that of a more startling nature, was about to take place in his views. The first indication of a plan which only the most ardent spirit could have formed, is given in a very remarkable letter from Charles to the father-datelessi, but obviously early in 1811-prefacing the subject with those philosophical and generalising reasonings which were congenial to his mind.

"Mr dear Fatier, - A resolution to be great in any "profession is generally accompanied by stern and um"damted modes and habits of thinking. 'He,' says 
" Foster, or nearly in these words, "who has made up his " " mind to be great, must accustom himself to habits of " "thought and action that to common observer's must “" ' appear like insanity.' In some professions, such as " mine, this daring being entirely mental, the individual " has no apprehensions of the cold, mistaken riews of the " world, for he is emabled to appear externally like the rest " of mankind, from whom, however, he is essentially " different. In other professions, though the daring be not " really greater, yet, as the hazards to which the individual " exposes himself are external and visible, the world is " influenced accordingly, and is apt to consider the enthu"siasm with which he voluntarily encounters difficulties as " something little short of madness. . . . To be great, " or perish in the attempt, is, of course, what I have long " made up my mind about, without fear of being thought " insane. This John has also done, but I am afraid you "will now think him mad, and, if he persists, I am sure I " shall think him so too. In short, to keep you no longer " in suspense, he has determined to explore the interior" of "Africa! He had been reading the proceedings of the "African Association some time since, and I then laughed " at the idea-but all of a sudden, within the last two days, " he has called on Mr. Macaulay, the secretary of the "African Institution, who has referred him to the African "Association. He has put himself under Mr. Firmeyer “ (who, in Brewster's 'Encyclopædia,' wrote 'Astronomy,') "to learn the use of Hadley's Quadrant; he is studying "Natural History; he has talked to $\mathrm{Mr}$. Jones about the "study of Arabic; he has written to Mr. Mrorton Pitt, who " is one of the committee of the Association; he has written " to Dr. Hamilton, another" of the committee, and called on " Lord Moira and Lord Hardwicke. Lord Moira received " him very politely and referred him to Sir Joseph Banks. "All that I have said to dissuade him having been useless, 
" or rather having served only as fuel to his flame, I can do "no more; but as affairs have taken the turn I have "described, I think it high time to write to you. I send " this merely that you may not be in the dark as to what " he is about, for it would be impossible to enter into a " detail of his motives and intentions, even if I could com" prehend them. I am afraid even you will not be able to " prevent his going."

Whether the father tried to divert him from this sudden and extraordinary scheme does not appear. At all events, it progressed with all the accumulating motive power which intensity of purpose, urged with singular enthusiasm and eloquence, could give it. John's special object was to explore the Niger, but his views embraced also the philanthropic, the commercial, and the scientific-the three great levers of human sympatly-and thus soon won over powerful friends in all these three departments. He dined with Mr. Wilberforce to discuss his plans. Sir Joseph Banks pronounced him to be the greatest enthusiast he had ever met with. The interest in him spread from the African Association to the Royal Society; and Government, chiefly in the person of Lord Liverpool, then Colonial Secretary, at length took his plans under their protection. John Eastlake prepared himself intellectually in various ways, by acquiring, as already hinted, the use of the quadrant-by mastering more than the elements of botany and chemistry-by studying the language and customs of the Moors-by learning to play on several instruments (he had lessons from Lindley), with a view to facilitating his intercourse with savage tribes, and finally by subjecting himself, for bodily training, to extraordinary fatigues and privations. Such ardour soon made his name known in wider circles, and the newspapers of the day gave it a wider circulation still. An extract from the Herald of the 10th June, 1812, lies before me. "Mr. 
" Eastlake, whom we have before introduced to the notice " of our readers, will soon sail. That enterprising and " enthusiastic character, whose object it is to explore the " interior of Africa, and who has taken every precaution to " avoid the difficulties to which Mungo Parke was subjected, " has likewise received the sanction of Government. He " is a young man of liberal education, considerable abilities, " and indefatigable perseverance, and we doubt not that he " will benefit the countries he means to explore, and bring " an accession to the resources of his native country."

In Jime, 1812, at the age of twenty-one, Jolm Eastlake started on his voyage in a Govermment packet; sailed to Goree and Senegal, and thence to Sierra Leone, where he occupied the ostensible position of Paymaster of the Forces. But the dauntless energy and noble ambition were too soon to be quenched. Shortly after his arrival he was incited by the chief of a tribe to visit him, and did so, remaining for some time in the Mandingo country. Finding himself attacked with ferer, he set out on his return to Sier'a Leone for medical advice, and descending a river in an open canoe, the damps aggravated his condition, and he reached Sierra Leone only to die. His death took place in January, 1813, just six months after his departure from England.

All such information as the family could obtain regarding John Eastlake's short residence at Sierra Leone was in keeping with the fervom and nobility of his character. The Governor, Colonel Maxwell, had become much attached to him: all who knew him there were deeply interested in him. He had progressed much in Arabic, "would speak nothing else," and was inuring himself gradually to the climate. Jolm left valuable papers and effects, which, unhappily, never reached his family. They were dispatched to England by the "Amelia," Hon. Captain Irby, but the vessel encountered two French 
frigates; many parcels were thrown overboard in the action, and John's effects are supposed to have been among them.

The afflicting * news of his brother's death reached Charles first through the newspapers. His depression was ahmost alarming, considering his youth; but he had been suffering before with overwrought anxiety regarding his picture, and this early acquaintance with acute grief seemed to paralyse him. He soon, however, met the stroke with the courage that might have been expected. "I am trying " to get over" the first shock by employment; but you know " how we loved each other." This employment, in addition to his usual application, consisted in drawing at Lord Elgin's gallery the then neglected Marbles of the Parthenon, with his youthful friend, the afterwards well-known Mr. William Brockedon, every morning from half-past six to nine. After this, by the mish of his family, and especially of his mother, Charles returned home, and there is a record of a portrait he painted of his old master, Mr. Bidlake, which was engraved. To this time belongs also a portrait of his dear mother in mourning for her noble son-a picture of great force-which shows the strong likeness between the sitter and the painter. He executed numerous portraits during his stay at Plymouth, for he alludes afterwards to improvement he had derived from " the months of portrait painting in " the country." 


\section{CHAPTER II.}

Severe Winter.-Expedition to Calais.-Lonis the Eighteenth and Duchesse d'Angoulême.-Return to London.-Visit to Paris.-Copying in the Lourre.-The splendours of the Lonvre Gallery in 1815._Remarks on principal pictures.-Admiration of Titian.-Leares Paris on return of Napoleon.--The Bellerophon in Plymouth Sound.-Portrait of Napoleon.-Jourmey to Rome.

Ox the return of our young Painter to London in December, 1813, he took lodgings at 5, Woodstock Street, Bond Street.

January, 1814, brought that severe cold and enormous fall of snow, which is still memorable in English annals. "The hackney-coaches," he writes, "here, are drawn by "four or five horses, and are more like ploughs in their " motion than anything else. The snow is constantly con" solidating, and whererer the pipes burst there is a well of "water down to the ground, which is very dangerous to "horses, and of course to passengers." He speaks of himself now as stronger, and more able to resist the depression of the atmosphere. One is also glad to read of "seven comntry dances," and of a risit to see Kean in Richard. February 28, 1814, "I wish you (William) "were here to partake the delight I felt. It is different "from any acting you have ever" seen. His "Off with his " 'head, so much for Buckingham,' makes the pit toss up "their hats with ecstacy; and when he dies (losing his "sword through faintness, and stabbing with his hand " alone, as if he still grasped his weapon, till his feet cease " to take root), every soul in the house stands up and 
" cheers. Before he retires to his tent, he is engaged for " a moment in drawing the plan of the next day's battle " upon the ground. Nothing can be finer. Everybody says " he is a second Garrick."

In the April of this year (1814) an event occurred, great in the youthful amnals of those days. On a sudden impulse Charles and a fellow-lodger, Mr. H., decided on crossing to Calais at the same time with Louis the Eighteenth, then returning to France. A sword-stick for each (his, borrowed from Kirkup, * a student friend) and "plenty of white cockades" were the chief preparations. The mail coach for Dover took them up at six o'clock on April 23rd, St. George's day. " White flags were hoisted everywhere; crowds were on the " road by 9 and 10 o'clock. Gravesend was like a theatre. It "would be in vain to attempt to mention all the modes in "which loyalty and happiness were demonstrated through " all Kent. . . . The Prince Pegent passed us before we " reached Gravesend, in a very private manner . . . . The " whole road from London to Dover was filled with horse "soldiers passing and repassing, and lining the approaches " of every town. Soon after we had passed Rochester, the "guns of that place and of Chatham fired, and presently " the King of France passed us, maccompanied by any "other carriage, but escorted by some military." Rochester" and Canterbury were in the same state of turmoil as Gravesend ; and Dover, which they reached in the evening, was brilliantly illuminated. Here some anxiety about passports, which had occupied their minds, appears to have subsided, and the inference is that they required none. How to cross the channel was the next question. Plenty of boats were at hand, but no one would take the travellers over that night under thirty guineas. 'The King's yacht, "gilt all over," lay at the end of the pier, and his Majesty passed the night there. Various arrivals took

* Mr. Seymour Kirkup, still alive, and resident in Florence. 
place that evening in Dover: among the rest that of Count 'Titschagoff, the Russian Ambassador, himself an evidence of the late isolating war's, for he conld not speak a word of English. The Count was about to sail, and was requested through his interpreter to allow the young travellers to form a part of his suite, but his Excellency declined the lonom. That night they rested a few hours at a miserable imm, with their swords under their pillows, and by six o'clock the next morning were on the top of the Shakspeare Cliff. By ten o'clock the military began to line the streets and piers, and the houses and cliffs were crowded to witness the departure of the restored Bourbon. "At one o'clock the "King set sail. The Prince Regent stood at the pier-head "waving his hat, thonsands around huzzaing, colours flying, " bands playing, sun shining for the first time, and cannon " roaring." Our young travellers had meanwhile found a passage in a packet-boat, the "Lark," which took then: for two guineas, and sailed ten minutes after Louis the Eighteenth.

They had a fair wind, and landed without interruption between six and seren o'clock. Charles thought of Hogarth as they passed through the gate of Calais. Then the young men, their number increased to three by a friend of $\mathrm{Mr}^{\mathrm{r}}$. H.'s, walked about the town, having ordered dimner at eight o'clock. The ramparts of Calais were in a ruinous state-the 36th regiment then in garrison. They also fell in with companies of the 24 th and 55th regiments. All was novelty and excitement, and Charles showed that he could still be a boy when manly duties might be put away. "The women were more rejoiced than the men-the "women full of vivacity, the men of sang-fioid. An " old lady at a shop where I bought gloves wept with " joy at the prospect of returning peace." The first impressions of the natives were most favourable. "As French "politeness is proverbial it may appear needless to men- 
" tion it, but form what irlea you please, I will answer for" "your being surprised with more kindness, affability, and "good breeding in the very lowest ranks than you conld " possibly expect. I was delighted with all, but especially "with the women. But though dimner was ordered at " eight, nothing was ready in the hotel at half-past nine, " and we were glad to satisfy our hunger with some veal "pies which I laid hands on in the kitchen. By way of "feeling ourselves in France we three had a bottle of " claret-fire francs. Presently I heard some violins, and "following the sound went into a large room where French " and Englishmen were smoking, and a girl of about twenty "with her brother, were playing duetts. He played ex"quisitely, and she soon after" sang in a way I shall never "forget. Her hair was very nicely curled on each side " of her face. I observed in her and in other women that " it was stiffened by some means to prevent its uncurling. "The elderly women paint their eyebrows black. After " enjoying the girl's music and talk I went up stairs with " Finchette, the 'femme de chambre,' to see about beds. "She at last promised to make up some in a ball-room. "The town was illuminated, and Finchette illuminated the "ball-room too. This was about ten o'clock. Then we " paraded the streets, which were well lighted up-and on " an archway saw a transparency with these words-

- Français! Louis 18 ramène dans la France

Le Commerce, la Paix, les Arts, la Liberté;

Relevons les autels de la Reconnoissance

Et ceux de la Fidélité.',"

Then follows a scene worthy of Don Quixote. "On "our return to the hotel there was quite a fracas about "beds. Finchette was followed about wherever she went "by dozens, wearying her with their entreaties for rest. "She herself had not slept for two nights-this made the "third-and yet she was not once ont of temper. It now. 
" appeared that people had got in and gone to bed with " the greatest sang-froid in rooms which belonged to others. "H. and I thought it prudent to guard our beds. The "French hotels are very spacious; this had a courtyard " inside and a suite of rooms all round it. Here, then, " there was plenty of room to race about. Finchette never " moved without.some twenty about her. While she was " wrangling with them, H. stole a warming-pan and we "both aired our beds. He was by this time very sleepy " and could not enter into all the fun (not understanding "French) which I witnessed. He accordingly went to " bed, first stealing all the blankets from another bed in " the room which was bespoken by an old Englishman. "After I was tired with laughing at seeing one room after " another broke open, I left Finchette to her persecutors " and went to bed too. Presently the old Englishman came " in-grumbled much on missing his blankets-and got " into bed without undressing. He had locked both doors, " the room being a thoroughfare, but in a few minutes " a crowd was clamorous for admittance. We made the "Englishman get up and open the door because he was "dressed. This he did over and over again, till he would "do it no more, and, learing the doors unlocked, the ball" room was soon the principal rendezvous. Suddenly a "door in the room which had escaped observation was " espied. It was instantly bombarded; behind it appeared "some tapestry-this was dragged aside, and half-a-dozen "lights flared upon the slumbers of some poor fellows who " were beginning to enjoy their 'prima quies.' This door, " it appears, was never opened, and was not the right way " into the room, the unfortunate inmates of which had " been disturbed often enough by the regular entrance. "I now put out all the lights, except a few near the " Englishman's bed, and all was quiet for a minute or two; "when, thinking on all that had passed, I gave way to 
" my feelings in a loud laugh. H. joined, when the " Englishman said, "if either of you young gentlemen have " 'taken my blankets it is a deuced shabby trick.' I as" sured him I was not thinking of the blankets, but his "suspicions being now aroused, he appealed to Finchette, " who entered, in a torrent of plaintive English, of which " she did not understand one word. I interpreted-she " took the injured man's part, -and both of them attacked “H.'s bed. I was laughing too heartily to assist either " party. The people in the room behind the tapestry, " hearing the noise, peeped in and joined in the laugh. "H. was worsted at last, and finally all was quiet-except " that various parties still scoured our room from time to " time, examining each bed and its inmate with their " candles. After this we slept till six."

That day the wind still blew from the north-west, unfavourable to return, with some rain, "but we were always "sure of amusement." They ascended the tower of the Hôtel de Ville for a sou each-then came down and watched the women catching shrimps-then made their way to where the Lancers were paraling. "Their captain, a very " fine young man, addressed them nearly in these words:" "Lanciers! Je suis chargé de vous dire que vos officiers “ " et vôtre général ont eu l'homneur de diner avec le roi " " hier, et sa Majesté a eu la bonté de vous agréér comme “" sa garde d'homneur jusqu'à Boulogne. Vive le Roi!' " upon which they all shouted 'Vive le Roi!' I after" wards understood that they were examined man by man, " and only one refused to acknowledge anything but the "French Nation and Liberty, and he was put in prison." Then our traveller's strolled into a convent and hospital, where the nuns were dressing up the door " with laurel and "white." And the nuns invited them into their chapel, where they looked at the pictures, and a "Sœur Elizabeth" was called 'qui aime les Anglais,' " and who made many' 
" inquiries about English names and families I had never " heard of." Soon getting tired of these ladies, they made their way back to Calais, and Charles, the spokesman, talked to every soldier and woman they met, and gathered information about "les gardes de côte," and the "Pom" piers," and heard Buonaparte called a "Casse-con," and nearly got into a scrape by praising his head on a Napoleon, and by asking some soldiers if they were "de la Garde " Impériale," who retorted rehemently, "Non-non-de " la Garde Poyale." And thẹ ascertained that eggs were only two sous per dozen, and meat infinitely cheaper than in England, and, in short, were amused with anything and everything, from the postillion's horn, to the women who acted as barbers, sharing the men, and the dogs who took no notice of "poor fellow, poor fellow!" Then followed the novelty of the table d'hôte, and the singing girl again.

But the principal event was reserved for the next day. The traveller's had set their hearts on seeing Louis the Eighteenth, who remained two nights in Calais. They accordingly went to the hotel where his Majesty lodged, passed all guards without remonstrance, and, joined by Sir Willian Curtis, stood where they could see into a room where the royal family were at breakfast. Finally they succeeded in entering a kind of audience chamber where the King and the Duchesse d'Angonlême soon made their' appearance. "The room instantly echoed with "Vive le Roi," " "Tive la Duchesse d'Angoulême,' "Vive le bon Louis,", " in which we of course joined. The King seated himself (he " walked very badly with the gout). Meanwhile our friends " the Nums, with some Priests, had marched in through a " private door. A kind of Master of the Ceremonies stood at "the King's right hand, and said: "Que les Religieuses " "s'approchent." They did so, and knelt round the King. "Their Superior said something which I did not hear, nor "the King's reply. When these had retired, the same man 
" said in English, 'Let the English officer's come and be " ' presented to the King.' There were several naval "officers, but not above a dozen English in the room " altogether. Officers, or not, we were all introduced. The "Master of the Ceremonies took me by the hand, I told him "my name, it was repeated to the King, and His Majesty "bowed. The English now stood in a body before him, and " he said, "You are witnesses of the first moments of my " 'felicity.' This was answered by shouts on our part of “ 'Long live King Lonis the Eighteenth!' 'The scene "already began to be affecting. I felt my eyes swimming, "and, looking round for support, saw H. in the same situa" tion, and an English captain with tears trickling down his " cheels. The Mayor of Calais now delivered an oration in "an impassioned French manner; assured the King of the "ficlelity of the Citizens, and hoped in return for ' un peu, " ' un petit pen' of His Majesty's affection. The King was "affected and answered kindly. The Mayor then knelt "down and kissed his hand eagerly twice. This was what "we had been waiting for. All the English were now at his " feet in an instant, and H. and I both succeeded in kissing " his hand. The Master of the Ceremonies repeatedly cried, “'Prenez garde au pied droit.' All this while the poor "Duchesse d'Angoulême was crying like a child. French " generals, English officers, Archbishops and Prefects were "alike affected. At this time the band began to play “ 'Vive Henri Quatre.' The King now retired, and within "five minutes got into his carriage, with six horses of the "most wretched sort, and ropes for harness."

The young men would have gone on to Paris, but for the " res angustre." They now left Calais by the same ressel, the "Lark," that had taken them over, and reached Dover. by half-past eight that evening.

Charles' immediate occupation in London was prompted by the rejoicings of the time-being a design for a trins- 
parency at the Bank of England. During the summer and autumn of 1814 he remained in London, working very hard indeed at a picture of Brutus; having a model at one time at half-past five in the morning, and occasionally taking a portrait. At the same time he continued to cultivate the French language with which he was quite enamoured;dined at a French restaurant, took French lessons, and also subscribed for a French newspaper; pursuing a plan for which few would have had the patience-that is, he persevered in reading the paper entirely through; a practice which he found of great service in mastering the language.

Meanwhile a plan of going to Paris to study the Lourre, still teeming with Buonaparte's spoliations, was gradually matured. Brother William, thinking only of Clarles' health, counselled delay, whereupon there followed one of those precise definitions in which the young philosopher excelled. "You talk of my deferring my tour for reasons to " which might be added a hundred others if I was a young "Nobleman about to travel for my anusement-whereas I " am an artist, going-no matter where, to see-a great " matter what-viz.: the finest pictures in the world, which " every one is afraid will be dispersed ere long. Besides, I " am arrived at that precise period of study when copying "from fine things can do me good-two years hence the " contrary would be the case."

The picture of Brutus was finished by the last days of the year, and, assisted by Mr. Harman's very liberal and judicious kindness, the preparations for a sojourn in Paris were made. This assistance was not confined only to the "sinews of war" but extended to introductions in no common tone to persons of no common order-bearing witness to the estimation in which the bearer was held-viz.: to Visconti, Denon, and Count de Laborde. On the 1st of January, 1815, Charles Eastlake arrived in Paris.

The first impressions of the French capital fully realised 
all the expectations of the young traveller. The Tuileries and the Lourve, eren unfinisher as the last-named palace was then, called forth all his enthusiasm. "The buildings of "London in general are barns compared with this exquisite " architecture, all peopled with marble statues, and glit" tering with brass ornaments. The arch of the Tuileries" (Carrousel) "would turn your brain. Well might Dryden " translate Ovid by saying of Jove's Palace--

'This place, as far as Earth with Heaven may vie, I dare to call the Louvre of the sky.'

"No royal palace on earth can be like it. I never saw " anything near it but the designs of poetical architects. "It is possible that it strikes me more from the imposing "and merely ornamental look which the French seem to " delight in. Ovals of variegated marbles, surrounded with "festoons, are let into the walls, and the splendour of the " contrast of a figure entirely gilt, upon or near pure white " marble, produces an effect which I thought beyond the "powers of architecture. It is odd, that my painting " frieuds who have been here shonld not have said a word " upon what has struck me so much. To prove, however, " that my opinion is not singular, Reynolds has said that " the façade of the Louvre is Perrault's masterpiece, and "Voltaire pronounced it one of the most august monuments " of architecture in the world."

Charles Eastlake lost no time in delivering his letter's of introduction; and to Baron Denon, and to a M. de la Vallée, secretary " de l'Administration des MIusées," he presented himself first, these gentlemen being best qualified to assist his object of copying in the Louvre. "Denon is all politeness and La Vallée surly, jusqu'à "l'Anglaise; but the moroseness of the latter' was well worth " the " mprofitable gaiety' of the other. Denon, however, " asked me to come and see him when I pleased. He is, I 
" suppose, more than seventy years old-the very picture of " what one conceives of an old, elegant, fashionable French. " man." Some private interest was needed at that time, for part of the gallery of the Lourre was unhung to accomme. date the modern exhibition. M. de la Vallée gave him permission to select any small picture by an old master thus displaced, and allowed him the use of a private room in the Louvre, where other artists-two French women among them*-were also painting. Charles selected a picture, a copy of which he thought would be acceptable to $\mathrm{Mr}$. Harman-the Vision of St. Paul, by Ponssin.

His introductions also gave him a little insight into French society; he attended a few conversaziones and a ball or two. The former were very "précieuses"- -some of the company reading their own poems. "Among the " circumstances in which this kind of meeting differs from " those in England may be mentioned the absence of every" thing in the eating and drinking way."

At this time-the midlle of Jannary - the cold was very severe, the Seine being frozen as far as the daily careful breaking of the ice permitted. He remarks that he sees no women with muffs, but plenty of men. "It is not an "uncommon sight to see old beaux going out to dine "towards the evening, dressed entirely in velvet, with a " muff, but with their hats under their arm, shivering along "bareheaded for fear of discomposing their powdered "wigs."

But while pursuing his copy of the Poussin with his usual industry, he did not neglect the glories of the Gallery itself; his impressions of which form a very interesting portion of his letters to Mr. Harman. By the middle of February he writes:- "I have now had time to get acquainted with the " principal pictures; which indeed requires time. In such a

* Charles Eastlake at that time mentions that a large number of French women carnal their bread by their profieieney in the Arts. 
" vast assemblage of fine works it is not to be wondered at " that one passes at first with indifference what in a private " collection would be the choice specimen. One has some " difficulty at first in reconciling abundance with excellence; " the usual characteristic of which is rarity. I onght not to "wonder at Reynolds not having been much struck with " the Vatican, while I conld pass many of the finest works " in the Louve without feeling half the impressions they " onght to excite. I remember, in particular, that Titian's "Martyrdom of S. Lorenzo, than which a finer picture does " not perhaps exist, hardly excited a passing glance on my " first walking throngh the Gallery. I have since atoned for " this by umbounded admiration."

The admiration of Titian, always the painter of painters in his estimation, was first imbibed here:- "It has been "observed that the Roman style (distinct blues and yellows) " resembles and affects one like martial music. I confess I "never was impressed in this way in looking at an in" harmonious picture. But Titian often excites feelings of "this sort. In the Pietro Martire the intense blue sky" the sparkling white of the clouds-the tall trees dark " against the distance-the evening gleam on the horizon" the assassination which is going forward-and lastly, the " majestic though natmal action of the escaping friar-all " seem to have this comnection with grand music, or rather "with the sound of a trumpet. If ever a picture was " miformly grand, this is."

He speaks again of the Peter Martyr, and all upon it from lis pen is the more interesting now that it has perished :*_" Reynolds in one of his discourses censures "Count Algarotti for describing this picture in a manner " (according to him) injurious to Titian's reputation, by "saying that the trees and the weeds in the foreground will

* It perished by fire in the sacristy of S. Giovanni e Paolo, Venice, in 1866 ; shortly after the cession of that city to the Italians. 
" bear the inspection of a botanist. Mr. Payne Knight, in " his criticism on Barry's Life (in the Edinburgh Reriew) " contends that Algarotti is right, and refer's his reader to " the picture itself. Accordingly, although Doctors dis"agree on this point, a mere inspection of this famous "work settles the question at once; for, though the fore"grotmd has been retouched, enongh of the master remains " to show that it was exquisitely and even minutely painter. "But this is not the only instance of T'itian's care in this " respect. In Lord Kimmaird's Bacchus and Ariadne," the "flowers and plants were executed with a beantiful accuracy, " and evidently from his hand."

Correggio also exciter his full enthusiasm, and remarks of the ntmost nicety and discermment follow, which, I think, he would not have been reluctant to endorse in later years. Young or old, Charles Eastlake was never lavish of such terms as "exquisite" and "divine." After describing the Madomna della Scodella, he adds:-“"The old man Joseph, "without having anything repulsive in his appearance, and "with a head and expression sufficiently agreeable, is, how" ever, far from being happy in the tout cnsemble. There is "something mpleasant in his dress and in the arrangement " of his drapery, and certainly a want of dignity. . . . . "The young Christ is sweetly drawn, and the head very "pleasing. The Virgin, without being decidedly beantiful, " has a most exquisite expression. The boy Angel, who "pours out water, though his head is partly hid, and the " other, who ties the ass, have astonishing grace and beanty. " 'These four heads-viz.: The two boy angels, the Virgin, " and the young Christ-are extraordinary specimens of ex"pression, and create that delight which perfection alone " can commmicate. All that can be said of these heads " belongs also to the beautiful St. Sebastian, St. Catherine, "and the Virgin in the Marriage of St. Catherine (II

* Now in the National Gallery. 
"Giorno). As I already know your sentiments about that "picture I suppose I shall not act contrary to your wishes " in beginning a copy of it as soon as circumstances will " permit. It is doubtful whether Correggio knew anything " of the fine antiques: if one may judge from these and his " other pictures, I am inclined to think he did not. What " is most to be admired in him is certainly entirely his orn. "I mean his wonderful feeling for expression which is often " in him (as in nature), independent of beauty of form. "There is an unaccountable mystery about this painter " which interests one still more for him. The best account " is that by Mengs, and it is an account full of doubts and "conjectures. . . . I do not find or ret feel that extr"a"ordinary harmony of effect and colour in these works for "which he is so celebrated, though there is always a silvery "brightness about his flesh which has a sweet effect, and in "point of colouring (in the flesh) he leaves little to be "wished for. But his prodigious excellence seems to me " to consist in expression; the more astonishing as it seems " to flow from his own mint unassisted by any other means " than a most dirine taste."

Charles Eastlake had far too much modesty and sincerity to descant much upon Raphael during this first early risit to Paris. He knew, as he has implied, that Sir Joshua passed the great painter at first unnoticed in the Tatican. He stood even somewhat puzzled before the Madomna della Sedia, though before long he felt the head of the Virgin to be "one of the finest in the Gallery." Of the Transfiguration, he writes, "It is said to have been "much restored, and I lare say has been, but there " is a strength of light and shade in it which I did " not at all expect." He paid due homage to the more easily appreciated qualities of Andrea del Sarto, Fra Bartolommeo and Paul Veronese, and was immediately struck by "the astonishing resemblance," then not so 
intelligently acknowledged, between the works of Bernardino Luini and Andrea Solario, and those of Leonardo da Vinci. "I suppose they were both pupils of Da Vinci; a head by "Solario seems to be a disputed point, and I am quite sure " his master never did anything finer."

His catholicity of taste, the true test of a real lover of art for its own sake, immediately asserted itself in presence of the varied excellences which shone in this great hemisphere. Rubens and Vandyck, Teniers and Ostade, all received unfeigned worship in their tum, and discriminating praise and criticism as well; and in the ardour of his nonexclusiveness, he adds, "I could sit down with pleasure " to copy almost any picture here, from Teniers to the "Transfiguration."

But the picture which may be said to have fascinated him par excellence was one, which, knowing the classical bent of his mind then, and the ultimate character of his own art, especially proves how alive he was to all excellence, to all truth of Nature. This was Panl Potter's Bull. "I " have been longing to speak of a picture which I conld not " well mention together with Raphael and Correggio; it is a "Cattle Piece by Paul Potter, the animals as large as life. "If this performance is not absolnte perfection of its kind, " it is, at least, the nearest approach that will ever be made " to it. I camnot describe the delight and admiration I felt "at first seeing it. The perfect imitation of the animals, " the unaffected strle of execution, the unquestionable day" light and air which exist on the canvas, are wonders of "art. I am not at all afraid of your seeing it after my " having thus spoken of it."

The erent which once more plunged Europe in war was now, however, imminent. Napoleon had left Elba and passed Lyons, and the painter had to turn from thoughts of art to those of personal safety. "March 12, 1815. (To "Mr. Harman). I am not afraid of any personal danger, 
"though the behaviour of the people here is manifestly less

"respectful to the English, seven hundred of whom are " said to have left Paris yesterday. All my French friends, "at least all who speak to me sincerely on the matter, "alvise me by all means to quit. They don't busy them"selves, however, much about the English, for", as they "very justly say, "How can we advise you, when we don't " know what will become of ourselves?" I have the " strongest hopes of being able to stay, though these are " founded principally on the consciousness of what I enjoy " here. But, whatever my regret at being possibly obliged " to leave this Paradise for painters, I have the consolation " of knowing that the impressions I have already received "from these master works will influence my taste for ever. "I feel my mind opened in the art in a manner which I " hope to express otherwise than by words. Another regret " is still more poignant, it is that of being deprived of the " best and only means in my power" of returning your kind" nesses to me. . . . My acquaintance with Visconti " had completed the sum of my delights here, and I was " Likely to gain everything useful to a classical artist from " such an advantage, which again I owe to you. Eustace " could not quit Rome with half the regret with which I " shall leave this place, to whose usually boasted attractions "I am, however, a stranger."

Charles Eastlake lingered till the evening of Sunday, the 19th of March, the same evening on which Lonis the Eighteenth left the Tuileries. The last line of his last letter from Paris was characteristic, "Heaven preserve the "pictures in case of an insurrection here." He and another Englishman reached Rouen the next morning at eleven, and stayed there that day, partly to see the place, and partly from reluctance to go farther from Paris. "But the next morning, Tuesday, our doubts were cleared "up; the post came in with tricolomed ribbons flying, and 
" the conducteur cracked his whip with "Vive l'Empereur.", Napoleon had reached Paris on the intervening Monday afternoon. "No sooner" was the news spread about Rouen "than we could perceive a sensible difference in the " behaviour of the people towards us. Two or three shouts " from some soldiers of ' ' bas les Anglais,' rather" annoyed "me. A scuffle took place between some of these fellows " and the volunteers (Royalists), in which the latter' were "victorious. We were not sorry to get into the diligence. "Our postillion hat thought proper to tie blue and red " ribbons round his hat, which attracted cries, some"times for the Emperor, sometimes against the postillion, "and always against the English." They made their way safely, but with delays and difficulties, to Dieppe, and crossed to Newhaven.

Our painter now proceeded at once to Plymouth, and there found plenty of demand for portraits, never a favourite occupation with him, though he turned it into a means of practical improvement. And here again, within a few short and publicly eventful weeks, his occupations were affected by those changes which affected the whole civilised world. 'The 'hundred days' had run their course, and Buonaparte reached Plymouth Sound on board the Bellerophon at the latter end of July. Although the vessel was anchored four and a lalf miles off Plymouth, the young painter daily took boat and hovered round, watching for every glimpse of the great captive with the keenest attention, and taking rapid sketches. His assiluity attracted the notice of Buonaparte, who, occasionally, by keeping in one position, gave the painter reason to believe that he lent himself to his object. He generally made his appearance at the gangway on the starboard side about six in the evening, when he bowed to the spectators assembled by thousands in the boats around. "When I was nearest " him he stood for about a quarter of an hour or more, 
"and seemed to be amused by examining the extent of " the crowd below him with an opera-glass. At first he " appeared with his hat on, but, since he has contrived "to assemble his risitors at a certain time, and the regu" larity of the thing has assmed more the appearance of "a levee, he remains with his hat off while he exhibits " himself at whole length. A suppressed cheer has more " than once greeted him on retiring, but it was, I suppose, " intended as an answer to the very civil manner in which " he takes leave of the company. . . . I hope, but for" " the object I have had in view (that of getting a likeness of " him) I should not have paid him that respect which more " than one risit implies; and, notwithstanding his dignified "appearance, I can see him yet reeking with the English "blood that has been lately shed."

These sketches resulted in a small, full-length portrait of the Emperor,* standing on the gangway of the Bellerophon, leaning on a bulkhead with his riglit arm, and holding an opera glass. He is evidently looling at the crowd below. As the uniform and decorations worn by Napoleon on these occasions were sent on shore by his authority for the service of the Painter, a description of them as seen in the picture may be permitted. He is dressed in the wniform of a Colonel of Chasseurs, dark green, with red collar and cuffs, and a red edging to the lappels: under his coat, on the left side, is seen part of the broad red watered ribbon of the Cordon of the Legion of Honour, and he wear's the large star of that order. 'Three small decorations hang from the left lappel of his coat, viz.:- the small Cross of the Legion of Honour, suspended by a red ribbon; the Order of the Pe-mion by a blue; and that of the Iron Crown by an orange one. His smallclothes are of white kersermere, with gold buckles at the linee; and white silk stockings,

* Now in Lady Eastlake's possession. 
with shoes and gold buckles, complete one of the most unbecoming costumes that a short, ungainly figure could wear. Nevertheless, from the interest of the subject, and the excellence of the likeness, this picture attracted a perfect fever of enthusiasm at the time. All who had come into contact with Napoleon were manimous in their approbation-all who had not seen the man were eager to see this. It was also taken on board the Eurotas, whither most of his suite had been removed, and there received the warmest eulogies.

The success of this portrait, one of ummistakeable individuality and great delicacy of execution, led Mr. Eastlake to undertake another of the Emperor on a larger scale from it. This was executed on a canvas eight feet high by six feet wide. It represented Napoleon, the size of life, in the same position and dress as that already described, but with other figures. Behind him, on the left, is the Grand Marshal, Count Bertrand, uncovered; behind, on the right, also uncovered, an adjutant. A marine is on guard on the left, and a sailor below is getting towards the main chains, where he always remained until Napoleon retired. The letter $\mathrm{S}$, on the hammock casings, indicates the starboard side. This large picture was purchased by five Plymouth gentlemen, who combined for that purpose. It was publicly exhibited in London and in the provinces, attracting great attention, and the painter received altogether and ultimately 1000 l. for his labour. The subsequent fate of this picture is unknown to me.

Having thus obtained comparative independence, Mr. Eastlake began to prepare for the accomplishment of his highest wish, viz.: a journey to Italy, and a residence of a year at Rome. His classical reading had been long directed to that view, and now he further qualified limself by the acquisition of the Italian language. He writes to Mr. Harman:- “ I find that the qualifications are without 
" end that would enable me to make the most of such "a trip. . . . . But I must remember that I travel "as a painter, and not as an antiquiry." With a mind so stored with classic lore this was no mmecessary reflection.

He started at the end of September, 1816, crossing the Chamel from Plymoutl to Roscoff, in Brittany, where he linded. Thence he took a long and circuitous route, but, it appears, the only one then feasible, first on horseback to Morlais, and thence by diligence to St. Brieux, by Remes, Nantes, Anger's, Sammur, Tours, Vendòme, Rambouillet, Versailles, and so to Paris. He observed and heard all that opportumity afforded on the way; the English look of the spires and hedges in Brittany-wolves not uncommon-twenty-five franes given for a wolf's head at Remnes-wild boars also a great terror-stories of the Vendéan war still current. He passed the height of St. Florent le Vienx. "Was it here," I asked of the conducteur, "that the battle took place?" "Le massacre," said he, correcting me. He was struck with a sign of the ancien régime in the wall enclosing the forest of Rambonillet-seven miles in circumference, so that the diligence had to make a détour; also with the preservation of game; partridges walking about in the fields near Rambouillet like barn-door fowls. When finally, after nine days' hard travelling, he entered Paris at four o'clock in the afternoon by the Champs Elysées, "the Place Louis "Quinze, the trees, the statues, the fountains, and the "palace, seemed almost like Fairyland."

At Paris he again attended some of those supperless conversaziones which he had mentioned before. They presented rather curious social features. "I was present at " the lecture of part of a new opera, Virginie. It was not "bad, but disputes got so ligh that I wished the author "good night soon after the first act. It is singular how " impassioned these people become without losing them"selves utterly, or" giving offence. They had no mercy. 
"One man would have it that Virginia, when she finds " herself in Appius' palace, instead of saying ' Oì suis je?' "should cry 'Laissez-moi sortir." A musician insisted " that ' ton époux t' attend' was ' un maurais vers lyrique;' "but when somebody hinted that the interest was not " enough exciter at the end of the first act, a friend of the "author's ingeniously proved the contrary by observing " that Madame was impatient for the secont. Such a noise "I never heard. I hope Molière and his friends were " a little quieter' at "Ninon de l'Enclos.'"

He also made acquaintance with some of the private collections in Paris, and speaks of one belonging "to a "M. Sommariva, an Italian gentleman, who seems deter" " mined to encourage the Arts it tort ct is tracers, for he has "liung the most detestable French things by the side of "Titian and Vandyck-employs French artists to copy his "whole gallery in enamel, and Italian ones to transform " his pictures into cameos and bas-reliefs. His patronage " of one Frenchman I cannot wonder at, for if any one of "them has merit he has-I mean Prudhon. The matter" "for astonishment is, that his colouring is chaste and " natural, and his expression and light and shade very very " like Correggio. A crying defect in all French painters, " though perhaps not so much their fault as their country's, " is that 'gout libre' which is such a terrible abuse of the "art, and which our countrymen are happily free from, with "one or two exceptions."

'These few days in Paris, however, secured a chief object of his ambition, viz.: the reneral of the acquaintance with Visconti, and letters from that distinguished man to friends in Rome; letters which showed that he had taken a just measure of the remarkable young Englishman. In Paris he heard so much of the chances of detention at that season of the year (October) in the Mediterranean, that he resolved to cross the Mount Cenis "in spite of the brigands," and 
to travel to Rome entirely by land. He left Paris October 16, 1816, and by all the English he encountered was at first taken for a Frenchman; this was from his command of the language, or, as he amusingly says, "because I wore "a brass buckle in my hat and ate fish after meat." At the time that peace had restored the liberty of travelling, few Englishmen possessed the power of speaking French. He took the road by Geneva and crossed the Jura, which gave him the first sight of "Alps which one may " see but not describe. I descended most of the Jur'a on "foot, and wore out my shoes by taking short cuts to "meet the coach." From Geneva, next day, the young traveller, then in the highest spirits, joined with a fellow passenger in taking a "char à coté" for Lausanne. "Ur"quhart har the honour of driving out of town, but as "the horse did not understand 'come up' and so on, "I took him in hand with 'en ronte,' 'sacré,' and those " kind of expressions which are known to be persuasive to "French horses-ride Tristram Shandy-and astonished " the natives of the Canton de Tand with a specimen of "superior driving." Arriving at Lausanne, he found out with difficulty Gibbon's house, made a slietch of it, and another of Coppet on returning; but the superior driving ended in an overturn, which did no one any harm, but occasioned expense and delay.

At Chambéry he took a vetturino through to Rome, there being no regular conveyances. "The lorses went "step by step, and I of course walked a great deal; and, " unless I was sketching, I was sure to arrive at any town "long before my driver."

But few and slight memoranda of the journey are left. Turin, Milan, and Piacenza were passed through rapidly. At Parma, Marie Louise had collected the pictures from the churches, with those retumed from Paris, into the Academy, and the Madonna della Scodella and the St. 
Jerome were already in that inner room where they have remained ever since. At Bologna, where the Academy was also already established in the same way, he speaks of the want of care too observable towards the pictures there and elsewhere. The Marescalchi Gallery at Bologna was then in its glory-_" the Judgment of Solomon,* an unfinished "picture by Giorgione, is very curious for an artist." At Florence the sculpture, antique and cinque-cento, seems to have especially engaged his limited time. Siena is also passingly mentioned. A day or two before entering Rome he was joined by a young Dr. Bunsen, then unknown to fime. The two young men entered Rome together on foot on the 21 th Norember, 1816.

* Now at Kingston Lacy, the seat of Mr. Bankes. 


\section{CHAPTER III.}

First impressions of Rome.-Mr. Cockerell.--Dr. Bunsen.-English Society. - Naples.-Tiroli.-Enthusiasm for Italian Landscape.-Starts for Greece.-Corfu.-Zante.-Patras._Delphi._Corinth.-Khemil Bey.The Plague.-Athens.-Sicily.-Return to Rome.

The young Painter was soon settled, in No. 1, Tia de" Cappuccini, "the people, a woman and her daughter, very " kind-and I am upon the whole better off than I ever "was in London." Letters of introduction were then delivered, and his French recommendations immediately opened the Villa Medici (French Academy) under M. Thévenin, to him, where he drew every evening and attended conversaziones every Wednesday. He also drew from the antique sculpture in the Tatican, then, with the help of the British Government, restored to the Pope. Phillip and Alexander Visconti, brothers to the antiquary at Paris, were also very kind to him. Charles Eastlake immediately condemned the style of modern painting at Rome, remarking that the modern sculpture was far smperior. "There " is, however, a French taste abont Canova;-a Dane, "called Torwalzen, is very celebrated, and firmer and "purer." Gibson had not yet come.

In Rome now as a young man, as in London when a boy, lie began by actire explorations on foot, and soon mastered its topography. He also soon reported himself as having been "in the ball of St. Peter's," which meant all over it. "But, whether from accident or an unconscious " impulse, I visited the ancient ruins before St. Peter's." 
He knew these so well from Piranesi's engravings, and from other sources, that the Arch of Severus, quite cleared instead of half buried, took him by surprise. He enters carefully into a rescription of the excarations made by the French, and then making by the Pope and the Duchess of Deronshire, which led to signs of original diversities of surface difficult to reconcile with the level of the Arch of Sererus. On the exterior of St. Peter's he was, as might be expected, critical. The disproportion between the means employed and the effect obtained was a direct inversion of his principles of art. "This is one " of the greatest faults I have to find-every means seems "to have been made use of to produce a deception on "the wrong side," that is, to make objects appear small which really are large. "To mention one of the com" monest;-in the inscription on the frieze of the whole " front, 'Paulus Burghesius Romanus, \&c.,' the letters are "about as high as a man, and you read them with ease " at any distance. Under this you see what appear to be "but moderately large columns, but when you stand at " the base of one of them, though they are not on pedes" tals, you camnot reach the lowest moulding. 'The sense " of the real size is the same in the end, but produced by an " effort of the reason, by laving ascertained the truth,-but " the imagination is the legitimate field for the arts."

He then passes on to a description of the Stanze of the Vatican. "Two circumstances have contributed to pre"serve Raphael's works here-lis peculiar practice, which "led him to excel rather in firm outline than in soft " effect-and to prefer hard distinctness to rich confusion; "and also the process of fresco painting, where it is " necessary to dig the outline into the wall. The fading " of colours mostly affects the draperies, which seem to " have suffered more than the extremities, where, the parts "bcing small, there was consequently more line. Here 
"and there are some cracks in the wall-this does no "great harm-what is worse is the ignorant folly of some "who have scraped lights in the eyes, \&c." He was then making drawings from some of the heads in the Stanza of the School of Athens and Dispute of the Sacrament. "There has been no possibility yet of working in the "Capella Sistina, so that I lave not seen so much of it as "I could wish. I was first struck on entering with a "tremendons depth of effect, both in the ceiling and the " Last Judgment, for which I was not prepared . . . . In "the summer the chill which pervades the rooms of the "Vatican renders it dangerous to work there, and then I "hope I shall do something in the landscape way. This " is a magnificent place for all that has to do with a " classic picture. Pines and erpresses present their dark " masses against the buildings and blue Apennines. Would " to Heaven you (Mr. Harman) were here! The finest " Nature and the finest Art never were more completely " blendled."

Again, to his sister-in-law-the excellent wife of his brother George-"Febrtary, 1817; this Spring is said " to be particularly fine. A Roman Spring! You can " conceive nothing too delightful for' it. 'The sum and "the Fine Arts are the sources of most of the impres" sions one reccives. I have no longer any doubt about " the effect of climate; and everything one sees in "the streets-eren the hand bills-have something to " do with art. By night too, suppose me now on the "Trinita de' Monti, on my way home from the Academy. "There is the city sleeping below, with its domes and " columns; and, that nothing may be wanting in the pic"ture, a single pine or cypress tree is seen among the " architecture;-higher, on the right, is the Villa Medici, "like a fairy palace, surrounded with evergreen oaks, " through which a fountain sparkles-nothing is heard 
" beside its murmurs but a flute or a guitar, and over" head is the moon without a cloud. And who does one " know in this fairy city! Who are to me its inhabitants! "the learner, the tasteful, the polite, and the beautiful. "Ought I not to be happy!" These were the bright impressions at twenty-three years of age, which as regards the outer world of Italy never wore off.

To his mother, at the same time, after describing the grand function at St. Peter's on Christmas Day, he adds, "Priests and artists are the great men here-tis a most " singular state of things-no commerce. I have only "to do with the outside of Rome, and nothing can be " more beautiful."

He next describes some of the young men-fellow countrymen and foreign-with whom he associated. "Of " all the artists who are here, Cockerell, the architect, is " one of the cleverest. He is the man who-in company "with Linck and Stackelberg, Germans-discovered the " Phigaleian and Egina marbles. He has brought a most "valuable portfolio of drawings from Greece. I heard of "him as soon as I arrived, and afterwarts met him at " the Duchess' (Deronshire). Nazois, the author of the “" 'Antiquities of Pompeii,' is also here. The first volume, "which is finished, he very kindly lent me, and will let " me examine everything as fast as it is printerl. $\mathrm{He}$ is " the only architect who has been allowed to measure and "draw the ruins thoroughly. Dr. Bunsen is the young "German with whom I got acquainted on the road. He " travelled with an Englishman called Cathcart. I break"fasted with them one day-took up a huge quarto and "found it a Latin treatise-took up another book, and "found it a Persian MS. This young man is now " employed in translating the oldest Persian poem, which " he has found in the Vatican. Sir William Jones, he says, " intended to have done it, but died without accomplishing 
" his wish. Dr. Bunsen takes me to-night to a Mrs. " Waddington, an English lady, who has three danghters. "I dined on Saturday with M. Thévenin, at the Villa "Medici, for the second time-met Cockerell, Linck, "Mazois-a man who had travelled in Asia,-and two "Frenchmen. Wre met to look over the grand work on " Egypt, published by the French Govermment;-immensely " interesting. Linck and I are going to look it through "again, and have fixed a day for the purpose. He is an "architect and an antiquary, and I shall learn more than " if I studied it alone."

At the same time the English society at Rome, headed by the Duchess of Devonshire and the Countess of Westmorland, who assumed to be leaders of art as well as of fashion, admitted our young painter to their soirées and dimers, which, though not long to his taste, were profitable in opportunities of meeting the chief sarans and artists. The Duchess of Deronshire was the first who gave him a commission, if such it could be called. She was engaged in preparing an elition of Horace's Jouney from Rome to Brundusium, with illustrations, and requested Mr. Eastlake to execute two of the designs. He selected the subject of Horace's departure from Rome and another, and his drawings were pronounced by Canova and others to be of a higher classical character than any that had been done. These he presented to her Grace. He afterwards painted a small picture of Yarius among the ruins of Carthage, in which he introduced the palm, the aloe, and the acanthus, and painted the architecture; also a picture of Cicero reading in his villa at Puteoli. These were both intended for the Duchess.

In the month of April, 1817, he started with his friend Mr. Seymour Kinkup-one of the young artists studying at Rome-for Naples. At first the young men had proposed to walk there and back, but finding a vessel in the Tiber 
bound for Naples they took their passage on board of her. Virgil was in Charles Eastlake's memory and Addison in his hand as they left their moorings under Mount Aventine, and floated down the river-the Campagna on either hand,"foundations of buildings, chiefly of reticulated work, in " and near the river. No living creature to be seen but wild "buffaloes. The trees have certainly been cut down since "Virgil's time. There are two mouths to the river" one by Fiumicino navigable-that by Ostia not. The " modem Ostia is not very striking, but the actual mouth " of the river-with a large tower, some picturesque build" ings, a lock bridge, and masts of ships against an Italian " evening sky-the 'Tiber glassy and golden, and the sea " meeting it suddenly, stormy and blue,-—was a singular and " picturesque scene. We slept upon the deck under" a sail. " The next morning, 8th April," (1817) "the whole of Latium " lay before us. Circe's promontory is so high as to be seen "from Ostia on one side and Ischia on the other." The course of the voyage did not rum smooth. "They passed the ruins of Antium ; wind contrary and provisions short. Got some bread at S. Felice on Circe's Cape. On the 10th they were beating off Terracina. The captain tried to run into a small river near 'Terracina, and struck his ressel on a bar two hundred yards from shore. "The wind was blowing "very strong to the land, the sails set. I looked upon an " upset as certain. The sea broke with violence upon us to " windward and the ship fell more and more on her side. " One of the sailors tore off his clothes, and I saw Kirkup " turn pale as he began to do the same. The souls in " purgatory and the Madonna del Mercato-a famous one " at Naples-were invoked audibly. 'They succeeded in "getting down the sails, and a boat came off" and towed us off " the bank and into the river, where the only somd we heard " was the croaking of frogs. Next morning we bathed for " the first time in the Mediterranean, and then walked to 
"Terracina, a most enchanting place, but one surrounded "by cutthroats. This is the "Scopulis latè candentibus " 'Anxur.' Sailed again that night, passed Gaeta, doubled "the Cape of Misenum, left Ischia and Procida behind, " glided by the Bay of Pozzmoli, Nisida, and the Cape of "Posilippo, and the sun set as Nuples rose before us, and " the red flame of Vesurius began to brighten as the night " adranced. We sketched the whole coast between us. . . . " We got Yasi's description of Naples, and being delayed "for two days by passports, we occupied ourselves in first " seeing the town. Yon find in the buildings first such "general resemblance to ancient taste as is seen in most "Italian cities. Next you find a particular resemblance to " the half Greek style of decoration which characterises "Pompeii and Herculaneum. Then you find the roofs of "the churches partly coloured by tiles-to all intents " painted. This is Moorish; for I make another division for "a certain Spanish or half Moorish taste, the natural " consequence of the connection of the two Kingdoms. "This last influence affects more than the edificess. Peter " of Toledo, Viceroy in the sixteentl century, seems to " have been one of the famons Spanish Governors. The "principal street is called from him the Strada Toledo. "Where River Gods are introduced the Ebro and the "Tagus are preferred to the Garigliano and the Vulturno. "You meet with Spanish inscriptions-the Guitar is "Spanish-the country people dance with castanets. If "you ask a Roman to explain to you twenty-foul o'clock " according to our method, he sars, ' 7 di Francia,' if you " ask a Neapolitan, he says, ' 7 di Spagna.",

To Mr. Harman he writes of some impressions derived from Pompeii. "August, 1817.-The painting of the " architecture which is introduced even on the outside of " buildings and on the capitals of columns I was glad to " meet with, because I had long had an idea that it was 
"practised, and the last researches in Greece and Egypt " prove that it was universal. It is also certain that the " ancients painted their statues.

\section{". . . . "Versicoloribus alis}

In morem pietâ stabat amor pharetrâ.'

"See a little epigram ascribed to Virgil. I am of opinion " that these facts may be made useful in art by increasing "the means of diffusing certain colours. For when a "painter can introdnce positive colour in his architecture " (I don't think I should be inclined to paint statues) he " need not resort to the various tricks in use to torture a "picture into harmony."

Returned to Rome he writes, "I have been making a " study-early in the morning, before I begin to paint,-—of " the remains of the Forum of Nerva*-a most picturesque " ruin; and as I have surprised some architects by it I " mean to go on with the sort of subject, and hope to bring " home some things that you will like. I may add that it "will be, and has also been, one of my objects here to "make a collection of classic trees. This is one of the "things Poussin excelled in, and, to say nothing of the " look of antiquity, there is a manifest absurdity in putting "English shrubs under an Italian sum. At l'erracina you " see a hill crowned with a picturesque convent-the sides " clothed with aloe and cactûs. On one side towers a palm, " on the other waves a grey grove of olives. If we are to "paint Romans in a city let us have their glorious archi"tecture-if in the country let such a scene as this be " spread around them-

" ' Know ye the land where citrons seent the gale, Where glows the orange in the golden vale, Where softer breezes fan the azure skies, Where myrtles spring and prouder laurels rise.'

* Water colour drawing in Lady Eastlake's possession. 
"This is the great good of visiting their country. If I do not " feel that I am in the 'Saturnia tellus' now, I can never " have more indications of it. The sum burns me into a "ferer" every day, but, far from enfeebling me, I never felt " more inclined to work. My passion for architecture and "classic scenery is such that I had almost made up my " mind to join two English architects who are going to "Athens in three weeks. Two reasons detain me-the " 'res angustre' and my reluctance to quit Rome before I "have done more in it. I long to derote myself to this "glorious Nature."

This language was in keeping with his belief that another year would be the utmost he could give to Rome-where he ultimately resider for fourteen years-at all events he needed no additional stimulus to industry. He adds, a few weeks later, "There is so much to be done here! If a man " uorks hard, and studies in Italy, he cannot stay too long. "Fuseli used to talk of an indolence and an indifference " acquired by too long a residence here, but if a man were " to work like a slave for six years he would carry home " but a very small portion of the region of taste with which " he is surrounded."

He now writes a letter to his mother from Tivoli, a place which the fine scenery, the classic associations, the light spirits and the earnest work combined to render an earth!y paradise to him. He walked from Rome thither-in October, 1817-with his manservant, a tall stont model (he sketches the master and man in his letter) carrying drawing materials on his head. "You are told that it is " death to cross the Campagna after" the rains, \&.e., \&.c. " How I could swell the list of horrors! but depend upon " it they are all imaginary, except the brigands, and they " seldom attack artists. The bad air, as far" as I know, is a " complete hoax, and I think I have been in every situation " where it is said to prevail. I have not had a moment's 
" illness yet, thank God. I drew in the open air in August "without an umbrella, whence the painters call me "the “' 'Salamander.' In the court-yard of the inn where I am "staying (at Tivoli) is the Temple of Vesta. Here one "loiters about in the evening, and hence you look down an " unfathomable gulf into which two cascades tumble. The " night here, says a French writer, has no silence. I will "tell you how we live here. We go out as soon as it is "light to paint and draw; then, at twelve, you see all the " painters, true as the dial to the sum, returning-some from "Mount Catillus, some from the villas of Mrcenas, D'Este, "the Temple of Venus, sc., to dinner. If they are "Germans or Italians they sleep an hour after" if French " or English they are out again immediately until dark, "when a supper is prepared, and when we English dine " together; and, having a flute and a guitar among us, the "Iabours of the day generally finish with the song and the "waltz. You may suppose that after six weeks' study from " nature in the most glorions scenery in the world, I know " a little more of landscape than I did."

He contrived to bring thirty oil studies, besides sketches, from Tiroli. These were the first fruits of his passion and his power as a landscape painter, in which character he has been too little known in his own comntry. In this line of art his refined taste and perfect command of the brush became the special admiration of all landscape painters settled at Rome, and gave, as I am assured at this day, a higher impulse and standard to their efforts.

On his return from Tiroli, a very fine model, "exquisite " in form and colour," tempted him to begin a picture of a classic subject. He chose Paris, with Mercury giving him the apple, figures the size of life, with the goddesses in the distance.* In November, 1817 , he is shocked by the tidings of the death of Princess Charlotte. "It has quite alarmed all

* Sir Charles lost all trace of this early picture. 
" the English here. 'They wear momming, and go to no "very gay meetings. Sorrow is miversal."

While this pictme was in progress, he was preparing himself for a trip to Greece, which had been more deliberately decided upon. On this subject, his kind brother William, a life-long invalid, of course felt some alarm, and no wonder. The young painter met it with more banter than argument. "The anxiety expressed in William's letter about my " intended trip is very natural for you to feel in Frankfort "Street; and the proposed joumey must seem as much " more formidable than that from Plymonth to Ridgeway" (five miles) "as the passage of the Arlriatic is longer than "that of the Flying Bridge. The only thing that can " make foreign travelling umpleasant is an ignorance of the " language. This I am already taking care of. I have met "with a Greek priest to whom I go every day from four " till dark. I have had abont twelve lessons, and can talk a " little already. Of course the little I know of old Greek " is of great use, perhaps of greater use than a deeper " knowledge would be ; for I should then have too much to " forget. There is no such thing as a modern Greek "grammar. I make a grammar as I go on. My master is " teaching the hereditary Prince of Bararia, $\dagger$ who is going " to ransack Greece for antiquities, but he says the Vasilefs " $\left(\beta a \sigma \iota \lambda \epsilon v^{\prime}\right)$ does not get on very fast. My picture and my " Greek are as much as I am fit for in a day (my model " comes at sumrise), so that in the evening I frequently visit " some Italian families. I am now strong enough in the " language to be one of them . . . . After all, the "Continent has long ceased to feel foreign to me, though "I can enter as much into our home liabits as when I left " England. 'T' is true I cannot here see the necessity of eating "before twelve at noon, and then prefer" a bason of soup to "tea; and in the evening can dine as well upon frogs, fried 
" artichokes, wild boar, and cuttle fish, as upon roast beef. "The climate is all one can wish. This is February, almost " over (1818); but from the first week the weather has been " like our finest May-the trees in blossom before they are " in leaf, the air refreshing, but the sum etermally unclonded, " and the moon the same; and such a city! The more to "be admired, the more one sees of it."

Mr. Eastlake's journey to Greece was again the fulfilment of an ardent wish, and this also, like his first risit to Paris, was encouraged by Mr. Harman's refined taste and enlightened riews, and facilitated by his generosity. The means for this undertaking were adranced by this excellent friend. Charles receired from him altogether $£ 300$, and repaid Mr. Harman by presenting him with the pictorial fruits of his tomr.

He started for Greece in the last week of March, 1818. His companions were Mr. Bary, an architect (afterwards the well-known Sir Charles Barry), Mr. Kinnard, also an architect, and Mir. Johnson, subsequently professor at IIaileybury College.

"Luggage small-mine consists chiefly of materials for " drawing and painting, for nothing is to be had there,-and " a mattrass for each, which is indispensable; and we take "Pansanias, Anacharsis, and maps between us. I have no " other object than the picturesque, and shall consider "myself at liberty to put the mosque and the temple in " the same picture, and to pay the same attention to the "Turl's beard and turban, as to the bas-relief he sits on." He adds to Mr. Harman a superfluous postscript, "Depend " upon my industry."

Our travellers proceederl to Naples, and thence crossed the peninsula to Barletta in four days. This is no familiar route even now. He describes the road orer the Apennines, howerer, as being better than that then betreen Bologna and Florence, though the inns so bad 
that the Vetturino did not attempt to provide repasts on the way for his travellers. Avellino was the first day's jommey, with an old town-hall, which they tried to sketch, bnt were surrounded by a large crowd, whose troublesome astonishment at such a novel proceeding impeded their operations. The next day they reached Ariano, the highest point on the road. Then they travelled safely through the Pass of Ponte Bovino, "a valley ten miles long, "and the worst for brigands in Italy; a number of soldiers "stationed in different parts, forts built, and the heads of "the dead robber's exposed. Nothing moves withont a "strong escort. About mid-rlay we saw some twenty men " on a hill near, but, as they did not attack us, never sus" pected them. We soon met a party of soldiers convoying "some mules laden with corn. Nothing conld exceed their "terror when they heard of the company we had passed. "We have since heard of an engagement." Foggia was their next resting place, and then they crossed the river Ofanto, and reached Barletta. "The Ofanto marks the "field of Canne: in this battle the Romans crossed " the river and attacked, and were afterwards beaten back " and perished in it and in its marshes. The bed of the river " is large, the opposite bank to the Romans-that is, the "south side-much higher than the other, so that they " must have attacked under every disadvantage." At Barletta no vessel for Corfu was to be had on reasonable terms, and they pushed on to Bari next day, passing several picturesque towns. "Talking of the Appian Way, at "Corignola, between Foggia and Bari, I found one of the "mile-stones in its phace, and have a sketch of it. After "giving 'Trajan's titles, the inscription ends with "Yiam a "Benerento Brundusium pecun : sua fecit.'” They sailed from Bari, and the next morning saw at once the west coast of Italy and the momtains of Albania. "At the distance "of twelve or fifteen miles, I saw from the end of Italy, or 
" what we call the heel of Italy, as far as Lecci, with "Otranto between. This was precisely what the Trojans "first saw of Italy, and not only from the same place, but " at the same time.

" "Jamque rubescebat stellis Aurora fugatis,

Cum procul obscuros colles humilemque videmus Italiam.'

" The epithet ' Inmilem' is strikingly correct, and 'colles' " instead of 'montes.' The opposite coast, seen at this " distance, was of a very grandly mountainous character. "Fano appeared first, then Corfu. A gale came on in the " night, but we consoled ourselves with the idea that we "were where Ulysses had been."

I now take up a species of jommal which he sent to his family after his safe return to Rome. The word 'safe' is no conventional term here. A journey like this, performed half a century ago, with such appliances only as a country afforded where there was no such thing as a post, even from the capital, was very different to what we now call "ronghing it." In the place of inns, steamers, handbooks, and photographs, there were perils of a very positive nature by sea and by land, which taxed to the utmost, (thongh rather indicated than told here), the health and nerve of the strongest and most enterprising; while in the case of the traveller we are following, there was always the peril of an overstrong sense of duty which had no mercy on his physical powers. But it is something to read a journal in Greece before Byron's “Don Juan” could be quoted.

"You know my travels up to Corfu. I will begin there. "I was there a week, and regretted quitting it so soon. "It abounds in enchanting scenes. There are plenty of "Albanians on the island, the remmant of a regiment "organised by the French. Corcyra is the Phœacia of "Homer (Odyssey). The medals have the gardens of "Alcinous on one side. The Coreyræan antiqnaries have 
"found this spot, and also where Ulysses met Nansicaa. "There are some remains- of the city of Crysopolis among " the olive groves. On the 19th of April (1818) we sailed, " under an Ottoman flag, in a Polacca brig,-ships' com" pany Greeks,- - for Patras, to touch at Zante. Some of " the Zante deputies to the Ionian Parliament were in the "ship, and a showman and his wife with their beasts and " birds. No part of the ressel endurable. We slept on " deck, and did not envy the Zante deputies the cabin. "Passed Paxu, and then Anti-Paxu, an minhabited island, " where some of the party went on shore. Previsa, scene of " the battle of Actium, at a great distance. On the 21st, " after passing Sappho's promontory by moonlight, we " were becalmed off Ithaca. Land all round. Cephalonia "and mountains of Patras in distance. Pindus covered "with snow. The wild beast man observed that the "Greeks were much fallen, for that "originally we had " 'rope-dancing and all other Olympic games from them.' "A Corinthian, dressed like a Turk, wanted me to do his

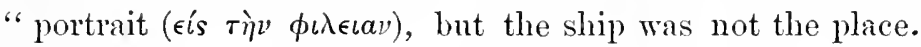
"Porpoises appeared, sign of the wind which came on and "took us into Zante that night. The bay of Zante is a " little like Naples in miniature. Behind the town are clay " cliffs, the lill is crowned with a fort, and, when I was " there, had the additional ornament of three men hung in " chains. Above the town are some olive groves, a few "small palms, orange and lemon trees, these laden with "last year's fruit. Sweet lemons are more delicious in " smell than in taste. Indian fig of an immense size, sc. "I walked to the top of the hill and saw the whole of the " island, an immense plain bounded east and west by " mountains, like one vast garden. Here grow the famous "currants; all the islands furnish some, and Patras too. "The pitch wells are also still productive. Sailer again; on " the evening of the $23 \mathrm{r}$ d were off Chiarenza in the Morea, 
" the wind failed, got into boat at stern and bather without " thinking of sharks. On the 24th, at daybreak, woke by "the Grecian cocks crowing, and anchored at Patras. "Here we found there was nothing like an inn, and Mr. “Green, the English Consul, kindly insisted on our staying " with him. He accompanied us with one of his Janissaries " round the town. Its antiquities consist chiefly of a "Corinthian capital, an altar, a mosaic pavement, and "foundations of a temple of Ceres, and some fine fragments " of statues walled into an old fort. There was one scene in "Patras which we sat down to draw. The Turkish waywode " was seated on a carpet under a plane tree near, smoking, " with two of his attendants. He called one of our party to " him, and examined him strictly as to his object in making" " a sketch; concluding by asking if he was a 'Milordos,' " - so this word has found its way into the language of "Plato.

"The wind not being fair to go up and across the gulf to "Salona, we tried to get horses and proceed on to Vostizza. "But this was the Easter of the Greeks, who reckon in the "old style, and they refused to work for" a week. The "Consul, therefore, got us a boat to row us to the Darda"nelles of Lepanto; we left him on the evening of the " 25th. We had now a Janissary,-one Abdallah,-and a "servant who could cook. The mountains were finely "lighted by the setting sum as we approached Lepanto. "Our crew were Greeks, with long flowing hair, or curled "like the antique statues. The Janissary, in an Albanian "dress, sat silently at the end of the boat, evidently looking "down upon us all. Monday the 26th we were in the "Gulf of Corinth, Lepanto behind us, Tostizza on the " 'starboard bow.' The heat was intolerable, and we " made very little way. In the evening, a contrary wind "springing up, we all pulled by turns, and got to Scala "di Salona carly on the 27th. This is where Anacharsis 
"lands when he pays a visit to Delphi. (The bay of "Salona is the gulf of Orissa). This place consists of "one building, the Custom House; it was empty when "we arrived. The Janissary went to Orissa, and returned " with the necessary number of mules and horses-three for " luggage and one a-piece to ride. The drivers were afrail " to go straight to Delphi (Castri), as no one had surveyed " us at the Custom Honse. We were therefore obliged to "go first to Salona. We were now in Phocis, a country of " mountains and olive groves. Everything appeared silent "and deserted, and the heat made it appear more so. The "first human being, and almost the only one we saw during "our jouney, was an Albanian shepherd boy, piping to his "flock. Salona, according to Spon and Wheler, is "Amphissa. The sum was scorching; we all made use of " our sketching umbrellas, but they frightened the horses, "and we had some droll adrentures in consequence. The " sort of road we passed over would surprise you, but the " horses never tumbled-they left that to us to do. "Thus we wound along the foot of Parnassus, oul "caravan looking like the procession in Bluebeard. When "we approached Saloua, which has five minarets and a "fortress on a rock, we saw a company of Greeks dancing " in a circle round an olive tree. After all, the Custom "house officer's at Salona did not visit us. Distances in "Greece are always reckoned by hours. From Scala to "Salona three and a half hours, from Salona to Castri " lather more. As I have rather surprised people by all I " managed to do in Greece, I can afford to confess that this " first day, though I passed through the grandest country, "and the most exciting to one bitten with classic enthn" siasm, it was the most impossible thing in the world not "only to draw, but, I may almost say, to lift up my eyes. "Yet, at this moment, the recollection of those Greeks "dancing in the grove before the Turkish town of Salona, 
" with a gigantic mountain behind it, is enough to make me " wish to return and draw the scene. I knew at the time I "should feel so afterwards, but the heat unmanned us all. "No sooner arrived at Salona than I drank a quantity of " water and dropped asleep. In our afternoon journey we " sent a mile out of our way for water during our march. " At Athens afterwards, in the hottest months, I never " experienced any lassitude or indisposition to work, and " yet I know it was a rast deal hotter.

"We now ascended Parnassus, arriving in the evening at "Delphi. The two rocks of Parnassus are fine as such, "but the mud town situated at their foot has nothing to "recommend it. It forms, like the old town, an amphi"theatre, which was once sustained by terraces of "Cyclopean walls, some of" which remain; but for want of "others the ground is one rapid descent of rocks and sand "from the town to a vast valley miles below, once watered "by the Plistus, which still flows through it in winter. "At present its dry bed is disceruible among the olives " that fill the plain of Crissa. The bases of some of the "terraces, with some traces of the Stadium, and a few "tombs hewn in the rocks, are absolutely all that remain of "Delphi. The Castalian fountain exists; it is a little " stream that issues from between the two rocks. A little " chapel is there, with Lord Byron's name in it. On the " site of the Gymmasimm is a convent.

"The town is wretched; it contains but two Turks; "all the rest are Greeks, who seem rery contented. " Whether it was on account of their festival or a constant "practice, they danced every evening. The Albanian "dance, as well as the Romaika, is practised by them. "Their music was a sort of small guitar with a long handle, " - a tabor", and now and then a violin of a guitar-like make " with three strings and as many notes. The long-necked "instrument was sometimes carried and played by the 
"leader of the dance, who had then a handkerchief tied " to his girdle by which the next held on. The others all " joined hands. They sing a long song with the music.

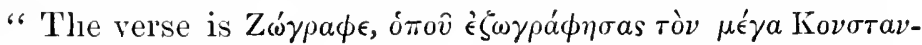

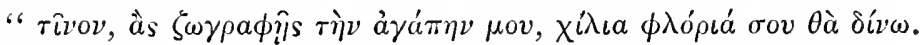
" "Painter who has painted Constantine the Great, paint me " ' my love and I will give you a thousand florins.' 'This I was " always greeted with when I made my appearance among " them. The inhabitants are very fond of shooting, and " never move a mile from the village without a musket; " but in the evening, if two or three happened to meet on " the brow of a hill, they regularly laid down their weapon " and began to dance.

"At Castri (Delphi) the custom of crying the hours from " the minarets could hardly be practised, for there are no " minarets, and only two believers in the Prophet. Instead " of this, however, a sort of town crier mounted the roof of "a house at night-fall and informed the village and the " echoes of Parnassus of whatever" was going on in trade. "This crier having offered his services to us, we made him " tell the inhabitants of Castri to bring us anything they " had to sell. They did so, and Kinnard bought a gold " coin of Delphi for" eight crowns, which has proved to be " unique and very vahuble. I made no purchases. The "Superior of the Convent was absent when we arrived, and "we could not be received there. We therefore fared ill in "a wretched hovel all the time-eleven days-we were at "Castri. Without any associations even, this is a romantic " and poetical place: you need not look at the print in "Anacharsis for an idea, for that is totally mulike. There " are no trees or verdure; the miserable town and fine " mountain are equally bare.

" There is a plane tree before the Castalian Spring, and " plenty of olives towards the valley and round the convent, " but Castri itself has nothing to assist its deformity. 'The 
" mountain, however, and the tremendous depth and dis" tance, gradual as they are, which you look down upon, form " a scene of the sublimest kind. The people talk very intel" ligible Greek-a little purer, I think, than the common "Athenian. 'The usual salutation on the road was “ ‘ " marked it as pronounced. When I could not understand " them I found them very intelligent in explaining them"selves by signs, thongh often accompanied by a lond bawl, " intended to enforce the thing. One of our party went up " the mountain to the Corcyran Cave (mentioned in Ana" charsis and Wheler) with $\Gamma \epsilon \omega p \gamma$ cos, our host. He found " some tombs hewn in the rock, and seeming to doubt at

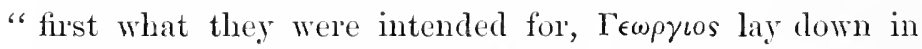
"one, shut his eyes, and pointed up to Heaven.

"Parnassus abounds in vultures. Lord Byron erro" neously calls them eagles. One of our purty oflered a " reward through the medium of the town crier for one of " these birds. A large bird was shot, but very different " from those we had seen sailing about the mountain. The " dollar reward was therefore withheld. At last a regular" " vulture was brought, with the naked throat. Its wings " measured nine feet from tip to tip. These birds rarely " came near the ground, and never moved their wings in "flying, but their rapidity was such that when they passed " overhead it was like the roar of a hurricane.

"We found many inscriptions here; the most conside"rable we were affaid to attack; it covered in very small " characters the whole of an antique wall which forms the " inside and back of a dark stable. It is probably inedited, " as may be some other's which we did copy.

"In mentioning the peculiar fondness of this people for" " dancing, I should not forget to tell you that always after " mass, which was sufficiently often, the whole congregation " danced and sung in the way I have described-the priest 
"with a long beard leading the measure, solemnly, but "actively. The resemblance to the Pagan customs is " evident.

" We intended to have gone on by way of Livadia and "Thebes to Athens, but news arrived that the plague had "found its way from the Negropont to Thebes. Afraid "that the gates of Athens should be shut against us, if we " escaped that danger at Thebes, we retraced our steps (I "walked) to the Scala di Salona, and sent the Janissary " to Galaxidi to find a boat. We slept on our mattresses " in the Custom House, and were woke in the night by the " shock of an earthquake; but this is common in Greece. " We started by boat next morning, but contrary wind " obliged us to go to Galaxidi-vile place! The wind con" tinuing contrary for Corinth, we crossed the gulf to "Yostizza, which was ruined last year by an earthquake. "On the shore at Vostizza is a large and venerable plane "tree, which, it is pretended, Pausanias mentions. Here "we got horses-I and another of the party walking-and "set ont for Corinth. The first afternoon we reached a "Priest's house, where we slept in an open kiosk; the " next evening we reached a khan, where we were accommo" dated with a harloft. The following afternoon we arrived " at Corinth, where we put up at the house of a physician, "dressed à la Turque, who speaks Italian. The whole " road from Vostizza to Corinth borders the sea: a small "plain between the sea and the mountains is most general, " but sometimes the mountain ends abruptly in the sea: in " either case the scenery is like that of a park in England, " except that the choicest trees here grow wild. We were " rather short of prorisions in this march. The second day "we halted at noon in a fine meadow. We were melted by "the heat, but refreshed by the sight of the snows of "Helicon on the other size of the gulf. After picking our "last bone, we drank some muddy water-the only pool we 
" found-but it was nectar. We got very little at the khan,

" and the next day we lived upon lemons.

"Corinth is a beantiful specimen of a Turkish town - the

"bazaar's sheltered by vines-groups of smokers in the

"streets about the coffee-houses-Turks in richest dresses

"galloping about on fiery horses; Bey's Palace, Seraglio,

" mosque and fountain, enriched with cypresses, and a black

" muezzin shouting from the minaret. The greatest man " at Corinth is Khemil Bey, the most opulent Turk in the "Morea. He happened to be out of the way, but we paid " our respects to a relation of his who presided at his "Palace. Our object was to be allowed to draw the house " - a very picturesque one; this was readily granted by "Ibrahim Golubeis, who politely forced us to smoke pipes " twice as long as ourselves with him, and gave us coffee à " la Turque-that is, sugarless, and almost solid with "grounds. His manner of boasting of the riches of Khemil "Bey was rather amusing. We were all ranged opposite to " him, rather lower than himself, all cross-legged. A "secretary sat at his feet, an interpreter on one side; "armed Janissaries were at the door. After taking a whiff " or two, he would say to the interpreter, without moving: " his head, "Tell them seven hundred families in the " Morea depend upon Khemil Bey for their daily bread.' "Another whiff. "Tell them so many bushels of cor'n (a " vast quantity) are consumed in this palace daily.' Then " followed the number of horses always ready, the black "slaves-not a word about the Seraglio-ending by saying " that guests had stayed one, two, and three years in the " house, and had not only been always welcome, but had "been supplied with horses and money on leaving the " munificent Kliemil.

"When the architects went to examine the house, they " must needs measure it, which Ibrahim not understanding, " ordered further operations to be suspended. I had been 
"sketching a mosque near, and wishing to see the turban "stones, went into the court, and thence was going amoug " the grares, when a black woman spied me, and rushing to "the door of the cemetery, spread ont her arms with the " most horrible shrieks to prevent my entering.

"The antiquities at Corinth are the columms-an amphi"theatre sunk in the rock, traces of Cyclopean walls and " Roman works-all very ruined. The Acro-Corintho, a very " high rock above the town like the Acropolis at Athens, is "said to contain some antiquities, but, as it is the fortress, " no Franks are admitted. We were between four and five " days at Corinth. The Physician with whom we lorged "receired accounts that the plagne was in Athens. This "was soon confirmed, and a boat, arrived thence on the "other side of the Isthmus, was put in quarantine. A "Frenchman suffered so much from the barbarity of the "Turks that, as we afterwards heard, he sailed round the "Morea before the quarantine expired, mable to endure it " any longer. I soon made up my mind to go on to Athens, " and was presently followed in this determination by two of " my companions, and at last by all. The Physician almost "went down on his knees to beg us not to renture. We "walked across the Isthmus (not six miles), and learnt " the truth from the Frenchman. The plagne was expected at "Athens, but the only deaths there had been in quarantine. " We sailed at night, and landed next day on a Pirate's "island (all the minhabited islands are said to be the " resort of pirates). This I did not suspect, but wandering " over the place to find a spot to bathe, I came to a little " creek, hemmed round with rocks, where lay a solitary boat. "Not a sonl was to be seen, and I was not curions to " examine further. In the afternoon we got between "Salamis and Egina-in the evening passed between "Salamis and the mainland-just the spot of the battle. "The setting sm lit Xerxes' throne (there is a rock still so 
" named).* In one of these silent bays there was another " boat at anchor, and our boatmen, without consulting us, " stopped and anchored near it. We had seen Athens at a " distance and were anxious to get on-and at all events " not to remain where we were. The moon was up, and as "there was no wind we agreed to row by turns, for the "boatmen refused to go on. We got up the anchor; a "rou followed, pistols were produced, and one man knocked " down. We pulled away, and in the morning passed by " the tomb of Themistocles, and anchored in the Pirens.

"I should have told you that at Corinth our Janissary "left us, for he was afraid of the plague. We despatched a "letter to the English Consul at Athens-Signor Logotheti " - to have his opinion about the plague. His answer" " advised us not on any account to enter Athens, but to go " elsewhere for the present;- - upon which we walked into " the City. There are only five or six houses at the "Piræens, perhaps not so many. The road to Athens-fire " miles-is the site of the long walls. Mounts Hymettus, "Anchesmus, Parnes, Corydallus, bound an immense plain, " and on the side nearest Hymettus rises the Acropolis and "Athens-the plain quite barren, and not even green next " the city-but at the distance of one or two miles the olive "groves begin, and end at the foot of the mountain. We " took up our abode in the house of one Demetrins Zo"grapho; the names of his children are Themistocles, "Alcibiades, and Pericles. There was once a Miltiades, and " there is lately an Aspasia. It was towards the end of "May that we entered Athens (1818). People were as" tonished at our boldness in coming at such a time. The "bodies of those who had rlied had been burnt, with all " that belonged to them. But a horrible sort of suspense

* This phrase was written, as already said, before Lord Byron's "The Isles of Greece" had appeared. 
" reigned over the city. I camot account for my being " indifferent to it-perhaps it was fatigue. Some of my " companions were very nervous, but when once we saw the "Parthenon and the 'Temple of Theseus, the plague was no "Ionger thought of. Admittance to the Acropolis was "purchased by a present of three or four dollars to the " Disda Aga, a very civil old man. The Greeks never go " there, so that we drew there in perfect tranquillity. "Athens quite came up to my expectations as a pictur" esque place, and exceeder them as a civilized one. The "Turks are really friendly. Among the Franlis resident " at Athens are M. Fiurel, the French Consul; Gropius, "the Austrian Consul; and Lusieri, Lord Elgin's draughts"man, \&e. These three, whose character's you will find "very illnaturedly drawn in the notes to Lord Byron's “ 'Childe Harold,' were very civil. I bore the heat well, " and worked under an umbrella from morning to night. " The 'Satellite' arrived shortly after our entry, and my "three companions could not resist the temptation of a "passage to Constantinople. They tried to persuade me " to go too, but I resisted them, and remained behind, the " only Englishman in Athens. From the day I first sat " dlown to draw, my life in Athens was every day alike, so " that the only journal I kept was not in black and white, " but in blue, red, and yellow."

Charles Eastlake contimued for many weeks the only Englishman in Athens. He mentions a number of travellers who subsequently arrived by English ressels of war. Among them were Lord and Lady Ruthren, Lord Balgonie, Lord Rosehill, Mr. Williamson, Mr. Wilson, Mr. Baseri, the architect, and others. With Mr. Basevi he went to Egina, about four hours' sail with a good wind. "The Temple " of Jupiter Panhellenins is beautifully situated in this "island, but situation seems always to have been an " essential consideration with the Greek architects. As 
"there is no house near, we slept two nights under the "temple, and the wind and the sun together took the skin "off our faces. The voyage from the Piræus to Cape " Sunium we performed in a night. There we stayed three " days, lodging in the temple as befor'e, for no house is " near. I made a most perilous journey of a quarter of a mile "over some rocks at the foot of a cliff to get a good point "for the ruin and the Cape. Here my ultramarine blew " overboard-there never was such a windy country as "Attica-but not before I had painted the darkest blue " sea that I suppose ever was painted, and yet not dark " enough for" what I saw; for here "the ocean is deepest in “" 'dye.' 'This sketch, which I was afraid would not be "liked for the excessive depth of its tone, is one that talics " most." Coming back from Cape Sunimm he slept upon some damp sand at the bottom of the boat, and caught a slight ferer or ague which laid him up a few days at Athens. He also rode to Eleusis and back again in the day, but he did not visit Miarathon. "I was of course always more " intent on doing than seeing."

Lord Balgonie had arrived in a gun-boat. In this boat was a sailor of the name of Magee, whose professional remarks on the Parthenon amused the English party. "Mr. Magee "rode up to the Acropolis on an ass, and having inspected "the Parthenon, \&c., he was of opinion that the place " might be taken with twenty men."

Under the auspices of Lord and Lady Ruthren Athens became rather gay, and two balls were given, chiefly to bring out the "Maid of Athens" and her sisters. "Whey "ure not remarkably beautiful, but interesting and lady" like."

After remaining in Athens three and a half months the arrival of the "Spry" from Smyrna-Captain White, twenty guns-gave an opportunity for leaving; and $\mathrm{Mr}$. Eastlake thankfully accepted a berth in the cabin with the 
amiable Lord Balgonie (the late Earl of Leven and Melville), while Messr's Wilson and Basevi were lodged in the gun-room. "We rode down again by the site of the "long walls, and when we saw the "Spry' lying at anchor " Wilson said with great effect, 'There are our long walls.' "The two Elliotts" (of Brighton), "who had come from "Smyma to Athens in the "Spry" (both fellows of Trinity, " and since gone to Egypt and Palestine) dined on board, "as did Mr. Wrench, the Constantinople Chaplain, who " had been living with me, and Mr. Hamilton Campbell, "Lady Ruthven's brother. Never were there a happier" "party. The getting into that ship was almost the same " as going to England."

They were a fortnight, owing to calms and contrary wiuds, in getting to Malta (on the 7th of October), where Charles Eastlake was not idle, as testified by an oil sketch of the well-known Caravaggio-The Beheading of the Baptist.

Sir Thomas Maitland was then Governor of Malta. 'Through his interest a schooner, 'The Regent,' was placed at the service of Lord Balgonie, who, with our painter, had formed a plan for visiting Sicily. "Our first " departure was rather unfortmate. Sir Thomas Maitland " sailed at the same time for Corfu in the 'Glasgow.' It "was found that he had left his papers and despatches " behind him; whereupon they were consigned to the " 'Regent' with directions to pursue the frigate. 'This " was done with success (I observed by the bye among the " despatches a good deal of music!). After which a gale of "wind came on and we put back-again to Malta. Next " day we sailed again with a Colonel Llewellyn, and in a " night and day crossed the stormy chamel of Malta, and "anchored at Augusta in Sicily. The schooner being a "vessel of war, our quarantine was, by management, "reduced to one day, so that we soon found ourselves in 
"Catania. The Bay of Catania is the 'Megarosque Sinus' " described among the other Sicilian ports at the end of " the Third Book of the 'Eneid.' Catania is supposed to " be one of the finest cities in Europe. I made a sketch of " the principal street, which reaches to the foot of Etna. I " did not go up the mountain, being otherwise employed. " My fellow-travellers attempted it without success. A Mr. "Cholmondeley joined us here. There are no antiquities " in Catania of any importance, but a curious private "museum exists. To Syracuse was one day, travelling, as " in Greece, upon mules. Here, there are some interesting " antiquities-a Temple of Minerva, turned into a cliurch; " some columns of the Forum ; tombs; the antique quar" ries; the Ear of Dionysius; the fountains of Cyano and "Arethusa, and Mount Hybla in the distance. Sicily has " one great adrantage over Greece, and independent of the "classic associations, namely the beanty of the country, " which is of the most striking kind. In Greece you have " frequently nothing but the name. The next place of note " was Girgenti, 'arduus hine Acragas' (all at the end of "the third book). Here are the ruins of four temples in "a line-that of Concord nearly perfect-columns of " Jupiter Olympius eighteen feet in diameter-the flutes, as "Diodorus Siculus observes, large enough to admit a man. "All that remains here is Doric. Selinonte--" Palmosa " 'Selinus'-is three days' journey from Girgenti. That " word "palmosa' made ne hunt far and near for' a palm " tree, but there are none nearer than seven miles. These "temples, five or six in number, are the most superb ruins "I have seen at all, but they are quite overthrown. From " Castel Vetrano we went to Trapani where Anchises died, " and the departure whence opens the Eneid. I went twice " up Mount Eryx and found some remains of the Temple " of Venus Erycina. The Temple of Segeste, near" "Alcamo, was the last piece of antiquity we risited. From 
"Alcamo to Palermo there are thirty miles of the most "Arcadian country imaginable. The temple at Segeste "and the mountains about it are all that Poussin could "wish. This corner of Sicily is well worth a joumey "from England to visit. I declared and declare still " that I never saw scenery before. Palermo itself is " enchanting. I went into the mountains for a week " to make a panorama of the town and ralley, but " not one hour would it cease to rain, and I painted " the skeleton chamber of a Capuchin convent..... "From Palermo a day and two nights brought us to "Naples."

He was back to Rome by the 20th of December (1818) bringing with him ninety oil sketches, many of them comparatively fuished oil pictures-all interesting works of art.**

Charles Eastlake was now just twenty-five years of age, and may be said to have anticipated a rare maturity of mind and experience, and that at the expense of no better thing, unless of health. He had already learned, seen, and done more than is often accomplished in the course of a long life. To these, in great measure self-attained, advantages he now added that of mixing in what might perhaps, not unjustly, claim to be the best society in the world. Rome was at this time the annual resort of much that was distinguished in English talent. For beside the mere brilliant crowd of title, fashion, and beauty, there were such people as Lord Spencer, Sir H. and Lady Dary, Sir Thos. Lawrence, Moore the Poet, Mr. Roger's, Turner, Chantrey, Jackson, the Miss Berrys, the truly accomplished Miss Catherine Fanshawe, and others; all coming and going, and leavening a mass, which, otherwise, by a natural law, tended eren in Rome to degenerate into

* A few of these are in Lady Eastlake's possession. 
frivolity, pedantry, and gossip. There was, no doubt, a higher tone in Rome half a century ago than there is or can be now. The magical city was more difficult of access, wealth was more exclusively in the hands of the better bred and educated, and people went for a longer time and with a more definite purpose. If, therefore, the Anglo-Roman aristocrats prided themselves on an exclusireness which is now of the past, they admitted, in self-interest, the acknowledged votaries of letters and art within the circle. And, generally speaking, all were seen to advantage in a city where learning, taste, and enthusiasm were the order of the day: where the blase found perpetual novelty, the intelligent perpetual interest, and where a glorious climate shed health and good humour upon all. Into this society it was natural for Charles Eastlake, with his raried acquirements and perfect refinement of mind and manner, to have ready admission; natural, too, that he in turn should greatly relish its manifold attractions. At the same time he was not the man long to enjoy or indulge in anything, however delightful, which interfered with a principle or a purpose.

At this period, however, all this had for him the zest of novelty as well as of appreciation, and was enjoyed with the ardour of an unvitiated youth. He had returned to Rome with a renewed sense of its beanties and delights, and with something of the feeling of a rictor, if such a name may be attached to one so modest, come to enjoy his laurels. His reputation was made at once by his Greek sketches, which were the admiration of initiated and minitiated alike, and the wonder especially of the former. For all persons conversant with the practical difficulties of art and climate had declared the impossibility of sketching from nature in oil under a Greek summer sky. Indeed, no one had been more positive on that point than Lusieri, Lord Elgin's draughtsman, in Athens itself. Here, howerer, was the 
unmistakeable harrest of an energy and endurance greater than had been brought into that field before by any oil painter, all bearing internal evidence of an accuracy and feeling valuable and fiscinating alike to scholar and artist. 
[Ch. IV.

\section{CHAPTER IV.}

Captain and Mrs. Graham.-Sir Thomas Lawrence in Rome.-Opinions on his Works. - Poli, and the Banditti.-Contributions to "London Magazine." - Death of his Father. - Visit to England.-Return to Rome.-Thoughts on Art, and on Painters.-Reputation as a Landscape Painter.-Death of his Mother.-Venetian Art.-Titian and Claude.Illness in Naples.-Lessing.-Rev. Hugh Rose.-Isadas.-Pagan Art. -Elected Associate of Royal Academy.- "Pilgrims in Sight of Rome." -..."Byron's Dream."-." Haidee."

He was now beset with commissions, not only for repetitions of Gireek scenes, but for sketclies of localities in and around Rome, and before long declared that he needed ten hands instead of one to get through his work. In this occupation, however, he took great delight; not only was he surrounded with scenes which ministered to his refined and classic taste, but, as he writes to his brother: "I have acquired a desperate fondness for nature, and " have added much to my happiness by following landscape "painting."

'The year 1819 was very happy and industrious. To the pleasures and flatteries of society he added the comforts of real friendship. Lord Balgonie was sincerely attached to him, and respected his character and his learning with a generous simplicity; while Captain and Mrs. Graham, who had come to lodge in the same house, cared for him with all the solicitude and interest of relatives. In this year he had moved into the louse which he erer after occupied, No. 12, Piazza Mignanelli, where the Grahams

* He vacated these apartments in 1830 in favour of his friend Mr. Penry Williams, who still occupies then. 
admitted him into their family life, and made themselves responsible to his dear mother for care of health which he too recklessly neglected. This was the lady, well known then and afterwards for her works on India and the Brazils, who later became the wife of Sir Augustus Callcott.

At this time Sir 'Thomas Lawrence was in Rome, quartered at the Quirinal (Monte Cavallo) Palace, having sereral fine portraits with him, male and female, and engaged in painting the Pope and others. Charles Eastlake gives a curious description of the impression which these works made on the foreign painters, chiefly Frenchmen, which must be measured more perhaps by what foreign portrait painters were then than by the present estimate of Sir 'Thomas Lawrence. "I went yesterday with the "President of the French Academy (M. Thérenin), a suf"ficiently bad painter but a very good critic, with the " best Landscape painter here, and with two or three "Frenchmen, an Italian, and a Pussian,-all artists. "Their admiration was unbounded. They said it was " 'l'école de Vandyck' which had formed that of Eng"land. They were very much struck with the viracity of "the execution, and with the science displayed in effect, " and not a little surprised to see them united with fine " drawing. The clererest Frenchman there was silent for" "some time, and when pressed for his opinion, said, in the " tone of a man who gives a thing up, 'Oh! e'est là la “" ' manière de faire les Portraits-c'est fini.' The manner of " painting gold, \&c., so excellent, but sô different from the "French, they were rery much struck with, and thought "it the best lind of high finish. (It is, as we all know, " anything but what is commonly called high finish.) 'Lors“ ' qu'on regarde,' said one, 'ces diamants à quelque distance " "l'effet en est admirable; ru de près ça parait indéchif" ' frable; il y a tout le cric-crac de la Nature.' In short, they " have conceived a high idlea of English art; still they will 
" not give up David as the head of drawing, and Lawrence "himself says he was very much struck with his power" in " that respect at Paris."

Sir Thomas, then in the zenith of his power and fame, formed for $\mathrm{Mr}$. Eastlake a sincere friendship, which he showed by much kindness at Rome, and many interesting subsequent letters. Lawrence was much impressed by his studies of landscape and architecture, and openly declared them worthy of Poussin. He also gave him a proof of regard, which those who knew Sir Thomas will understand how to value, by presenting him with a sketch of a lady's head by his hand, and allowing him to be present while he painted it. Charles, in return, gave him sketches of certain localities in and near Rome. The head was that of Mrs. Graham, a very remarkable specimen of two hours' work, which Sir Charles never parted with. The stuctio, his own, where the lady sate, was large, with a fine light. He placed it shortly after at the service of Jackson while engaged in taking a portrait of Tom Moore, and thus, as he expresses himself to Mr. Harman, "I saw the Painter" "work, and heard the Poet talk."

During the summer of 1819, which was intensely hot, he spent a short time at Tivoli, and also joined the Grahams at Poli, near Palestrina. From these two trips he brought back sixty sketches. At Poli, the banclitti who infested the neighbourhood completely blockaded them, and Charles Eastlake went ont with the peasantry to gire them chase. The scene of a poor girl lamenting over the borly of her' murdered brother made an impression upon him which he afterwards transferred to canvas. From this short stay at Poli may be dated the interest he took in banditti subjects, which afforded in every sense fitting foregrounds for his fine landscape studies, and for which a person in Rome furnished all necessary costume and materials. Nor did oral information ficil. In a picture of a woman, in the 
costume of Solmino, giving bread to an old man seated beside one of the little Madonna chapels near Subiaco, which Mr. Eastlake gave to Mrs. Harman, the model was "a bandit's wife, who had been a frequent sitter to me. "Her first husband was put to death-her present one is " in the galleys for fifteen years. I hope the act of charity "she is performing in you" picture may destroy these " associations. She may at least be suffered to do good " in a picture. Even in nature the most contradictory " mixture of good and bad qualities is one of the peculiari" ties of these people. The men robbers are generons and " crnel by turns, and the women watch over their safety " and hazard their lives for them in circnustances very fit "for picturesque representation. This has accordingly "given me a hint for several pictures which I have done."

It is curions to think of the lawless elements only divided by a few miles from the highly artificial and luxurious society of Rome. "The Romans are quite in"prisoned, owing to their" own fears and the daring activity " of these brigands." On occasion of a visit to Larly Westmorland and Lord St. Asaph,-who had asserted their independence by taking a villa at Arsoli, in the wildest nook of the Apennines, abont twenty miles beyond Tivoli, on the borders of the kingdom of Naples, - the banditti hovered so persistently around them, that the Lady and young Lord, who had carried with them all the luxuries and habits of the capital, were obligerl to return in a week. Charles Eastlake seems to have trusted to the belief that they let painters alone (not always verified), for he was out sketching from daybreak to noon, and foumd the scenery so glorious that he ontstail his hostess.

While his hand was thus busy, his mind was equally active. Mr. Scott, author of "Visit to Paris," sc., had been in Rome foraging for contributors for the "Lonclon Nagazine," a literary periodical started in Jamnary, 1820. 
In the course of 1819 , Mr. Eastlake furnisher lim with six articles. 1. On the Excavation of the Tiber. 2. On the Arts of Rome. 3. On a passage in Dante. 4. On finding Cicero's MS. in the Vatican (copied into Galignani, April 14, 1820). 5. On an Italian treatise on Moral Philosophy. 6. On Italian Music. At the same time he devoted his evenings to learning German, and mastered the language for purposes of speaking as well as of reading. A few months later he translated Bertholdi's work on the Secret Societies of Italy (the Carbonari).

The penalty of all this spendthrift industry was now, however, becoming due, and took a form in which the offender could least aftord to pay it. He began to suffer from an induration of the glands of the eyelids, brought on by overexposure to strong light, which produced swelling and inflammation. His general health also gave way, and though ten days at Civita Vecehia, with sea-bathing, rested and restored him, yet from this time he may be said to have been always more or less weaker than his task, however mrelentingly towards himself that task might be pursued and achieved. While mwell, his thoughts dwelt on a return to England; but, as he rallied, his numerons commissions and the pictorial charms of Rome again riveted him to the spot. This was subsequent to the departure of the Grahams, whose society he not only greatly missed, but whose tender care over his health was more than ever needed.

In December', 1820, the intelligence of lis excellent father's death reached him, and, yearning for his afflicted mother, he immediately started for England. Arrived in Plymouth he began a portrait of his mother in her deep mourning, which shows how finely he conld treat this branch of art. It is evident that the question of his settling in London was now mooted by his family and friends-the Grahams being at that time also in London; - but, if he left England with any immediate intention of 
returning, it quickly eraporated, equally before the consideration of the hazardous conditions of a painter's life in England, and the irresistible attractions, picturesquely speaking, of Italy.

As regards a painter's life in England, it must be remembered that Art in those days, unless we except portrait painting, - to the practice of which $M r$. Eastlake was never disposed,-was no smooth or lucrative profession. And though our painter was indifferent to the small prices which his works obtained, yet he was anything but indifferent to the means then sometimes necessary to obtain patronage. "I doubt," he says, in a letter to his dearest mother, "the possibility of my getting on in London "withont resorting to more quackery than is consistent " either with my feelings or profession. Here, I need no " incitements to work, for the place itself is inspiring, and " the difficulties of living not great. I feel Italy and my " own pursuit very differently of late. In short, I like both " much more than ever, and am determined to lead the "quiet but industrious life of a mere painter. Indeed it " now seems to me that I never felt Italy before. When "I thought of portrait painting in London, it was not that "I preferred this branch of the art-quite the contrary; " indeed the style, of all others, I should like would be " a union of History and Landscape, which is not, I think, " dividing the attention, as it teaches one to look at a whole. "I have considered that, on the whole, this would be as "profitable a pursuit as any, without the unspeakable " annoyance of portrait painting, under which I am sure "I should sink before long. Historical painting, merely, is "too hazardons, for when a young man has made himself "a bankrupt in strenuously aiming to produce something " tolerable, to be at the mercy of such ignorant puppies as " the . . . . (naming an English paper), \&c., is not to "be borne." 
When Charles Eastlake spoke of being determined to lead the industrious life of a mere painter, he, as usual with him, fully meant what he said. Accordingly he immediately formed and adhered to the plan of refusing all dinner engagements, except on a Sunday, on which day he also resolved not to work. This order of things gave opportunity for more expression of his thoughts regarding Art, in which he indulged to Mr. Harman. "It is the fairest mode of " criticism to enter into every man's particular feeling, and " to give lim credit for that-without condemning Ponssin "for want of colour, or 'Teniers for rulgar form. A " character is always more respectable than a great deal of " excellence without one; if excellence indeed be at all " attainable without it. . . . . I have made up my mind " that poetry more exclusively belongs to landscape than to " figures, and I shall always hope to make that principle, " viz., a poetical feeling, the rule of composition, colouring, " light and shade, and all. I have followed the art long " enough to find out what my own feeling is, and it is only " by following that that I can hope to make other's feel."

Again, as to the deeper things of a Painter's philosophy, I venture to transcribe the following extract from a letter to Mr. Harman, Angust 6, 1821:-“Erery man, at some "period of his life, naturally asks himself whether the "profession he is engaged in is worthy, or may be made " worthy, of a gentleman and a Christian. The conviction " that the one I have the happiness to follow is wortly " of both not a little increases my love for it and desire " to excel in it. Whether what Reynolls says be true, " that 'what begins in Taste will conclude in Virtue,' I " know not; but I sometimes hope that at some distant " time it may prove so in my case. This does not fail " to attach me the more to what I have learnt to con" sider the possible means of attaining it. But such an "arduons profession as Painting will not bear too close 
" examination with reference to moral duties. Reynolds "ventured to say, that he would never be a painter who "looks forward to Sunday as an idle day. Opie went still "further, and recommending industry with enthusiasm, "says, a painter must give up body and sonl to aiming " at perfection in his art. In my own particular case I " am sure I have done more since I have ceased to work "on Sundars. But when I said that Painting will not " wholly bear the test of reference to moral duties, I meant " and mean that such an absorbing pursuit, eren if it does " not prerent the artist's fulfilling, in an imperfect way, " his duties to God and himself, yet interferes materially "with his attention to the rest of the world, his neighbour. "Are Painter's, then, umprofitable labourer's? or" rather do "they toil only for their own aggrandisement? I answer" "this by supposing that the contemplation of works of art " must produce in a proportionate degree in the beholder. "the same effect which the practice sometimes produces "on the painter. Although it has been doubted whether" "Painting erer prodnces a moral effect, its abuse is rery " capable of an immoral one; and the first step to make " it of use should be to shum its abuse. The subject (of "a painting) has also much to do with its possible good "effect, and most of all the excellence of the work, so "that the most moral painter has the strongest motives " to aim at perfection in the art itself. While I think that "a painter's only chance of success is to follow his omn "bent, I sometimes regret that mine is decidedly a heathen "taste, for I see more to allure me in the beanty and " simplicity of a classical dream than in the less plastic " and less picturesque materials of my own faith - the "very excellence of which is that it does not appeal to " the senses. I have thought, indeed, that the two might "be united in sacred landscape, for the scenery of the "East has always been fine, but I cannot help thinking, 
" with respect to History painting that all the machinery " of the art - the picturesque - has little to do with " Christianity, the purity of which is better expressed by " the early Italian painters and present German painters, " than by Venice, France, or England. Painting and "Sculpture, which were always excluded by the Jews, seem, " to be ill-adapted for a religion which was planted among " them, and which confirmed instead of changing their "laws. The reason why the arts were not sanctioned " among God's people is obrious, for the Greeks owe " their idolatry to their artists and their poets-till at last " erery benign or sinister appearance in nature was looked "upon as a Deity. But what a beautiful system for a "painter even now! What I have said has nothing to "object against the arts now, for the world is changed " and enlightened, and a Christian may make an image " without adoring it."

Mr. Eastlake was one of the few who ventured to remain in Rome during the heats of the summer--he did so in $\mathbf{1 8 2 1}$ and 1822. At these periods of the year Rome was deserted, and he worked almost entirely without interruption. "I "find the summer is the time when I work hardest and " improve most, and I have enjoyed this last the more "from economising my time and strength in the Italian " way--viz., by sleeping during the hot hours (le ore calde), "from one to three. From three to dusk is then a fresh "day, and in the morning of course one is the stronger "for it, from not requiring so much sleep. But the prin"cipal reason for my bearing up so well this year is my "plan of bathing in the river every evening at twilight. "I swim in consequence better than ever I did-thongh "that is not saying much-in short I swam across the "Tiber" and back in a wide part without the walls, and " the rapid current makes this a long operation. I shall "not repeat this because it is sometimes dangerous." 
'These were his summer plans. In winter he was accustomed to rise at dawn, "meeting the sun upon the " upland lawn," and "seeing it gild St. Peter's." Returning one morning he met Mr. Rogers, then going out, and who, priding himself on his own early habits, asked him if he lived in the country. In the evening he regularly drew at the Academy-one raised by subscriptions among the English painters. No wonder he gained the reputation of being the most industrious artist in Rome.

Hitherto his works in Italy, between the years 1816 and 1820-21, had been confined to numerous sketches from Italian nature, and in Greece and Sicily-and to a number of pictures of scenes in and about Rome and of the ruins in Greece, further embodying the fruits of his studies there. His first reputation was thus acquired as a landscape painter-a character in which he is comparatively unknown in his own country. And there are those still living who bear witness, as I have hinted, that the poetic view he took of Italian landscape created such an impression on all landscape painters-foreign and Englishthen at Rome, as considerably to raise the standard of that art. The development of his fine feeling for colour may be traced and was by himself attributed to the study of Italian landscape. "I am quite convinced that there are certain "principles in art which can only be acquired in Italy." On the other hand, the refinement of taste through which he riewed all things and by which all he touched is most surely identified, may be claimed exclusively as his own.

From 1821 to 1823 was the period when he was led to treat a number of Banditti subjects. These served as a further occasion for indulging his love of landscape, and at the same time gave a romance of a quasi-historical character to his scenes, which appealed to a larger public. Sereral of these were exhibited at the British Institution in London in the spring of 1823, when the novelty of the 
rich colouring, as well as of the subjects, made a great impression. Their moderate size rendered them the more desirable, and in the words of the Secretary (Mr. Young) he had "continned offers for them at the Private View, at "almost any price, and could have sold them fifty times " over." These were, however, all commissions received in Rome from English visitors. As to Sir Thomas Lawrence, thongh proverbially the politest of men, yet we need not doulut his sincerity in the generonsly kind letter he wrote on this occasion. "Yon prove that the air you have " chosen to breathe is at least not enervating to the genius, "but to that salutary, as it is delicions."

At this time another and a severer loss befell him. His beloved mother died in July, 1823. He remained in Rome, drawing nearer than ever in affectionate correspondence to his brother. William, but feeling more and more that his sphere of happiness was restricted to his art. In this respect he had more ambitions hopes than any Banditti subjects could fulfil. The principles of Tenetian colouring now began to oceupy his mind. He remarks on the change that gradnally takes place in a painter's eye who long resides in Italy. At first he had felt the cloudless sky an evil, as giving no opportunity for those accidents of light and shade on which English art mainly and justly depends. " It is strange that I never dwelt on the system of the "Venetian school till I had myself discovered the way in "which Nature herself atones, if I may so say, for this "want of light and shade in hot countries. In short the " character of Nature here, and in the works of Titian " and others, is to produce light and dark by colour-the " noblest and most general system of imitation. In Greece, " the sea and sky are sometimes the darkest parts of the "general picture. The monotony of a sandy ground is " reliered on one side by the sparkle of marble, and on "the other by the depth of the cyrress and evergreen 
"oak. So much for inanimate nature, but we find the "deep rich tones of men and animals, and eren the dresses "of the first, all combine to make amends for the want " of that shadow which the northern climates have without " colour. The Tenetians, therefore, formed their style from "the study of Italian nature."

Again, in a letter to Sir Thomas Lawrence; *

"In such a climate as this, where Nature is constantly " seen by the general light of the sky, and nothing destroys "the integrity of colour, it is impossible not to feel the "truth and largeness of the Venetian system. In the " general (and therefore beautiful) effects of Nature here, "the office of shade is only to display form. In a darker " climate, and in interior effects, it often conceals both form "and colour. Whenever these last-mentioned effects are "common, they will be considered beautiful, for our ideas " of external perfection can only depend on our experience " of nature. And it becomes a question whether this " general character of Italian colou" can be relished, or "fairly judged, on the other side of the Alps-for such " effects, in England at least, are not common enough to be " recognised as true."

Then later, he says (September 4, 1823), "In all the "pictures I have now sent to England I have put in "practice the system I endearoured to describe to you. "There is very little light and shade (except in the land" scape) and a great deal of deep colour. In a hand, for " instance, by the time the half lights and shadows are " done (both differing from the colour of the light) the " mass of flesh colour is lost. In the Venetian pictures " and in nature looked at lingely, the local colour ends " only with the outline; and to give the utmost quantity " the Venetians make the outline also warm. This, I

* Extracted, by kind permission, from the correspondence of Sir Thomas Lawrence, in the possession of $\mathrm{Mr}$. Keightley, Charter House. 
" consider, forms a considerable part (applied to every" thing) of the brealth of colour so admired in Titian."

Again, "The simple question, what is the general cha" racter of the object to be represented, explains the style " of Titian, for he always penetrated it. Many appearances " in nature lave more than one general characteristic by " "which they are universally recognised. Thus, while "Titian aimed at the quality of depth in the sky, Clande " seems to have loved another of its attributes, and, re"flecting that the sky was the source of light, he seems "to have determined that brightness was its universal " character.... Titian again, like Homer, characterises " the sea by its colour; Claude loved to express its motion. “' 'The deep blue sea,' and 'the moving waters,' would " both be considered characteristic epithets in Poetry, and " both would be universally recognised. Again, Claude " seems to have copied the forms of trees in a relative point " of view-their forms assist his composition, and their " tone gives brightness to his sky; but Titian always ex"pressed the universal character of a tree-viz., grouth. "It is always bursting with the efforts of vegetation. The " forms are hence often peculiar, and at first one would say " that Claude is more general in his choice of trees; but " what appears accident in Titian's case is really the " character. 'Thomson applies the epithet 'irregular' to " trees, and it is more miversal than any other that conld "be quoted."

With such feelings fresh upon him, Mr. Eastlake executed a picture with half figures, life size, called "The Champion," representing a Norman-Sicilian knight in armour, challenged by a Saracen, and preparing to follow the herald, while he receives a scarf from a lady. This gave him the opportunity of painting armour, of which he always felt the picturesque capacities. The picture was exhibited in the British Institution, and brought a letter from Haydon, who, 
with the discrimination in art which never failed him when criticising the works of others, dwelt on its "Titianesque " simplicity."

It was after the completion of this picture that his eyes again gare him trouble and anxiety. The English medical men in Rome knew little of this particular complaint, and in March, 1824, he proceeded to Naples to consult an eminent Italian oculist. Dr. Quadri treated the suffering eyelids sererely, and the inflummation that ensued was as serious as tedions. But his nature was one that rose to any trying occasion: he wrote subsequently, "The possibility of losing " my sight altogether at some future time, instead of " making me despond, has determined me to make the " most of it always and only for things that are worth "studying." After tro months of almost solitary confinement, he hoped to have been able to snatch a fer sketches of "this enchanting scenery. The mountains on the eastern " side of the bay are precisely what I want for my Greek "landscape (Brron's Dream), and the sea at their base " is the same in all respects as that which I remember in "Greece. The colour of that sea, opposed to uninhabited "land, gives a solitiry and desolate character to the Greek " coast, but here the palaces along the shore, always bright "from the purity of the air, produce a contrast to the eye " of a gem-like character, and is such as I have nowhere " else seen. The colour of Vesurius is also very fine-it " is a brownish purple even now when every thing is too "green." But he adds what, to those who knew his peculiar feeling for glowing colour, has a mournful sound, "I dare not look at sumy objects yet." Eventually he left Naples without any addition to his stock of sketches.

He deroted this time of solitude and confunement to maturing those thoughts upon art which form the basis of some of his published essars, and which are also scattered through his correspondence. It was shortly after 
this, as I have reason to believe,-namely, in the spring of 1825,-that he first fell in with Lessing's "Laocoon," which he ever regarded and cited as a canon of true reasoning. In this remarkable work he found the confirmation of that system of definition, as respects the principles of art, to which his own mind naturally tended, and from it again he struck ont new and somd ideas peculiarly his own. No one ever conversed with him on the philosophy of the Fine Arts without being impressed with the clearness and precision of thought and definition which he ever brought to bear on these subjects, so opposed to those vagne generalities which generally embarrass them. At the same time he freely acknowledged the difficulty of accurate definitions in matter's of taste; and deduced, indeed, a certain adrantage to the artist from that very fact. In a letter to Sir Thomas Lawrence, December, 1824, he thus touches on this subject. "The principles of "art are so difficult to arrest by words that the natural " differences of tastes and opinions are greatly angmented " by the ambiguity of terms. The consequence is a distaste "for all theoretical communications on a subject where "real excellence is only to be attained by unremitting "labour. And art perhaps rather gains than loses by "this inclination to repress truth itself for the sake of " avoiding disputes that would rather tend to make critics "than professors."

It was also about this time that he made the acquaintance of a gentleman of great originality and cultivation of mind, who has left a name still remembered and honoured among those who had opportunities of appreciating his merits. I allude to the Rev. Hugh Rose of Horsham, known as a theological writer of ability. He was in Rome in the winter of 1824-25. Mr. Eastlake writes, "I have made "one very agreeable acquaintance here this winter-Mr. "Rose, a clergyman-he is a man of the finest mind 
"and wholesomest judgment I have met with for long.

" $\mathrm{He}$ is, I hear, considered one of the best Grecians in

" England. He preaches at the English Church, in a way

"I have seldom heard. He is here with his wife and

"brother, and a young man to whom he is tutor. Of "all the men I have known in Rome, his ideas on the "philosophy of the arts are nearest what I believe to be " right. I used to think a man of taste an easy thing to "meet with, but I have been now long convinced that " the principles of true taste are connected with much " higher elements than many are aware of; and there is " no other way of explaining the perfection to which the "ancients carried all the arts. I was in doubt whether my "dreams on the subject would be intelligible to any one " else, but I find he understands and agrees with me "so readily that I may possibly publish something some " time hence." *

It was at the begimning of 1825 that $\mathrm{Mr}$. Eastlake began a historical picture for the Duke of Deronshire. Returning to his classical predilections, he chose the subject of Isadas the young Spartan, who was taken for a divinity in battle-from Plutarch's Life of Agesilans. He thus describes it himself:- "The Thebans had crossed the "Eurotas and attacked Sparta, a city without walls, and " undefended by nature, except in some elerated place "where the sacred buildings stood. It was thus in immi" nent danger of being taken, when Isadas, son of "Phobidas, rushed naked from a bath into the battle, "armed only with a sword and spear. His youth and

* It would be difficult, within the limits of this memoir, to name all those to whom Mr. Eastlake was indebted for kindness during his residenee at Rome. Among those who came and went, Mr. Etty and Mr. Uwins, both subsequently members of the Royal Academy, may be gratefully recalled. Nor can I omit the name of MIr. Erskine, of Linlathen, still surviving, who exerted an influence over many admitted to his socicty, which, happily for them, was of no eranescent kind. 
"beauty, added to his being entirely without defensire " arms, inspired both assailants and defenders with the idea "Gthat he was some guardian Deity-perhaps Castor. His " courage completed the illusion; he struck down a man at " every blow, and, though everywhere engaged where the " danger was most pressing, he received not a single " wound."

While convinced, in his own words, "that Painting is "greatest when it interests without the aid of words; and " while I have endearoured, and always shall endeavour to " work on this principle, yet I have added quite learning " enough to please the bookworms." He accordingly adds an explanation of the learning displayed in the picture, which, as it is probably not preserved elsewhere, I renture to insert here:- "The Eurotas winds " in the distant landscape; the buildings are remarkable " in the history of Sparta, particularly the Portico of "the Persians-a trophy of rictory over that people. "The building is mentioned by Vitrurius as well as "Pausanias, and was the only one in Greece, besides that " supported by Caryatides annexed to the Erectheum at "Athens, where figures were used instead of columns. The " large Ionic temple in the distance may be that of Minerra "Chalciœcus (the house of bronze), though I have not "found it convenient to show any bronze, excepting the " bronze statue of Minerva (before the steps of the Temple) " round which the women are clinging. The drapery is " either real cloth, or bronze painted red-red being the " colour of the Dii Majores when their statues were painted. "Her helmet is gold. . . . She holds two spears, as was " usual for an armed hero or goddess. She is chained to " the pedestal, by which precaution they hoped to secure " the presence and protection of the gods. When Alexander "took Tyre he found the statue of Hercules loaded with " chains, for the greater the danger the more they were 
"fettered. The fillet round the pedestal consecrated a "statue during the performance of sacred rites. The " architecture, at least the Portico of the Persians, is pas " tially painted. The altar smoking in front of the great "Temple occupies the place where the sacred rites were " generally performed. The Spartans, being a hardy race, "are distinguished by iron lielmets-the Thebans have " them of yellow metal. The Thebans are also distinguished " by the well-known form of the Theban shield, with two " indentations on each edge; painted slields were common. " The serpent on three of the shields alludes to the Dragon "origin of the Thebans.

"I need not tell you that a God-like figure to a Greek "meant a pre-eminently beantiful human being, and "althongh my figure is in rapid action, and looks fit to "destroy, yet his beanty of form is what is most dwelt on " as being that most likely to make him pass for a god. "The strongest of the enemy are immediately opposed to "his young and comparatively delicate form. One is " already struck, and falls headlong over the wall; another " is vanquished already by his fears; another adores; and a "fourth is in doubt whether to resist or fly."

He thus vindicates this attention to the classic niceties of costume:- "The English colourists generally despise cos" tume, or will not take the trouble to make the necessary "researches: but if it can be showed that costume can be " contrived to aid rather" than comteract the harmonious " effect of a picture, it is surely worth attending to. I should " be the first to neglect it if I were not persuaded that it " may increase the materials of efiect and colour."

'To one who remarked on his choice of a Pagan subject, he answers :- "Every work of art which exhibits beanty in " any form is at once heathen, whaterer time or names it " may belong to. The general impression of nature in "which beauty resides (which is the soul of art) is the same 
" thing as the religion of the ancients. The reason why " they attained such excellence, and why the moderns can" not hope to rival them, is that their devotion and their " taste were one and the same interpretation of nature. . . . "The power of genius has done less in modern times " than the docility and discretion with which the ancients " interpreted nature. The business of the artist is only to " define the intention and general principle of nature. This " is taste. He is next to define the appointed means of " attaining this end (representing this intention), and this " is style. . . This is no fancy. I believe in the existence " of an innate and involuntary approbation of all that is " consistent with the intention of nature; and we can define "beauty in no other way. The principles of natural "religion are by no means so certain as this, for it would " have been impossible for the human mind to have arrived " at a true system of morals withont the aid of revelation. "But the Christian, whose first principle is the suppression " of human caprice as opposed to the Divine will, is less " teachable than the heathen in all that relates to pride of " intellect."

"The simplicity and docility" (this letter was to Sir 'Thomas Lawrence) " with which the ancient artists inter"preted nature are directly opposed to the modern omni" potence of genins. Character, both in mind and matter, " was the direct object of their imitation, and the fame of " the great modern masters rests on the same basis. The " mind of the workman is thus supposed to be, in a great "measure, passive. He has only to define the nature of " things; he must never create. The just imitation of "the general impressions of nature must please; and " wherever" a work of art, professedly conducted on such " principles, fails to please, either the artist's definition " of what is truly nature, or his mode of expressing it, are "wrong." 
Again, he says,-in words which may be quoted, although they partly repeat what has gone before,-on giving advice regarding the education of his brother George's children:"As the intention of nature opposed to mere human caprice " is the great principle of taste, so the Divine Will, as " opposed to that of man (naturally contrary to it), is the "great principle of morals. Docility of mind, and a sense " of our creaturely relation, are the great requisites, and it " is much more possible to put young minds in the right. " track than to turn old ones from the wrong:"

This picture (Isadas) created an extraordinary sensation in Rome, and he for once adopted the Roman custom of throwing open his studio to the public, when above a thousand people flocked to see it. Pome was the place for its archrology to be appreciated as well as its drawing and colour. Isadas pleased the artists of every school. Two Dutch gentlemen expressed the curiosity they had felt to see a work of art which all factions and parties agreed in eulogising. M. Grérin, then the Director of the French Academỵ, said he had nerer" seen a work "arec une physio" nomie plus antique et classique."

It is interesting to know whom the painter himself most desired to please :- "Sir Joshua recommends an artist to "work himself into a belief that his performance is to be " seen and criticised by the greatest in the style he aims at. "I laboured for Flaxman's approbation among artists, and "I need hardly tell you for yours (Mr. Harman's) among " comnoisseurs. That great genius is no more ; but it would "be pleasing to me, could those who mulerstood his tastes "think my work might have gratified him aş an effort "towarls his own world of beauty."

The picture was exhibited in Somerset House in 1827. Sir Thomas Lawrence weleomed it with enthusiasm, and provided for the framing and rarnishing still necessary, as if it had been one of his orm. Its merits, howerer novel in 
the school of the day, were warmly acknowledged. It brought him a characteristic letter from his friend Mr. Etty, from which I give an extract:-

4, Buckingham Street, Straxd, Aug. 25, 1827.

“Dear Eastlake,-I at last have taken up my pen to " let you know that I am still yet in existence, and yet think " of you ;-indeed how conld I do otherwise when you have " sent such a splendid reminiscence as the one in the last "Exhibition? I write you this to congratulate you on it. "I write also to tell you that I have taken the liberty of " putting down your name among those who are desirous of " becoming Associates of the Academy. If I have done "wrong, you must scold me. But, joking apart, I hope " they will elect you. It is with men, like you, of genius "and classic erudition, that its front ranks ought to be " filled.

"I should be so glad of a sheet full of news from classic "ground, when you have nothing better to do. And say " does the sum shine, untired, as beautiful and golden as " ever. Of Venezia, cara Venezia! I often think; her "Gondolas-her Palazzos-her Lagunas; and last, not "least, her tones-her mrivalled colom! Have you drank " at her enchanted fountain? 'Drink deep, or taste not'" as of the Castalian spring: that you have drank of ; your "works avow it"... .

Etty's expectations were realised. Mr. Eastlake was elected an associate in the following November; the first man ever admitted to membership, while an absentee.* Sir Thomas Lawrence, ever kind to him, anticipated the Secretary's official announcement by a day, and as his letter reflects equal honomr on the writer and the Academy as on him to whom it was addressed, I give it here:-

* Mr. Gibson, the sculptor, was the second member so elected, and was also the last. 
"Russell Square, Nov. 6, 1827.

"Mr DEAR SIR,-I hare the sincerest pleasure in ac"quainting you that you were last night elected an "Associate of the Royal Academy. Your fine picture for " the Duke of Devonshire presented so happy an example " of the union of Academical study with fine composition " and classical research, as very greatly added to the former " impression of your talents; and fully confirmed the hope " (or rather confident expectation) which had been formed "on the obvious improvement in your recent labours. You "were elected by a very large majority, and I have never "witnessed in the Academy a more general satisfaction "than when the result of the Ballot was made known. "Your competitor was a gentleman of acknowledged talent, " and whose immediate connections hare a just interest "from age and high respectability in the Academy. The "question of numbers (though I have alluded to them) is " often matter of chance, and eren in Jour case will not be " estimated (I am sure by you) as the true scale of com"parative ability. But I wonld not conceal the fact, "because it shows you the jealous attention paid by the "Royal Academy to the claims of genius and character, "however separated from them by absence, and unsup"ported by those means of influence which the friendships " of the Candidate, when present, so naturally create."

To his friend Mr. Harman he expressed his sense of the honour done him in characteristic words. "I am glad of "any inducement to labou" more and to aim higher, and "I like the responsibility which accompanies any degree of " public and mequirocal distinction."

Another testimony to the attaimments and character of Mr. Eastlake may be here mentioned which had reached him two years before, namely his election as one of the original seven hundred member's of the Athenæum Club.

I have no intention to describe all his pictures as they 
follow in time- a complete chronological list of their subjects and dates is given at the end of this short memoir; but I may be allowed to allude to the next picture he executed, as the one from which his peculiar and almost pathetic refinement of expression may be said to date. Here we first trace that enchanting type of female hearls, the peculiar sweetness and purity of which, however helped by reference to models, was supplied from his own standard of feeling. The Duke of Bedford had expressed the desire to have a work by him " relating to the manners of the South." Mr. Eastlake proposed "Pilgrims arriving in sight of St. Peter's " at Rome." The Duke in answer remarked that he did not perceive it to be a subject of great interest, though leaving him entirely free; fortunately the painter pursued his own idea. He writes of it to Mr. Harman: "I am " considerably advanced with a small picture for the Duke " of Bedford-subject, Pilgrims arriving in sight of St. "Peter's. It has cost me, as every picture does now, much "trouble-more than the result wonld indicate-perhaps "so better. I feel more than ever the importance of "graceful arrangement, and never can come up to my "wishes on this point. The imitation of nature, however" "refined, is tolerably safe and secure work in comparison " with the arrangement of the masses and lines of a compo"sition. No part of the art, I am convinced, requires more " taste than this: it is where a painter" can be helped least, " and where he must draw most on his own powers. It is, " in short, the most creative part of the art, more so than " even the expression of the passions; because for these we " have a native and common feeling to guide us, and nature"in "detail to look at. But the elements of Beauty, applied to " the conduct of a picture so as to produce that effect which "attracts and enchants the spectator at the first glance, "require more of the artist than any other branch of the art. "Flaxman, who now only lives in his works, was great 
"in composition, and seems to have been thoroughly " imbued with the spirit of the Greeks. That spirit is, I " have no doubt, applicable to every part of the art. It is "more easily attainable- where the practice of nature is to "be interpreted-but where her principles (the causes of " beanty) are the sole ground, the difficulty of arriving at a " satisfactory result is far greater. Yet the Greeks consulted " the principles of Nature only in all those parts of art which "are not strictly imitative-such as architecture, furniture, "vases, ornamental foliage, \&c. It is precisely because they " never failed altogether, but are nearly equal in all their " arts, that they must have had some clear principle."

While this picture was in hand, and indeed for long before, the beautiful landscape known as "Byron's Dream" had been gradually maturing under his hands. This was for his friend Lord Leven and Melville. These two important works saw their termination about the same period-the end of 1827. At the same time lie transmitted the head of a Greek girl, called Haidee, which he requested Mr. Harman to accept. He writes, "It may be called Haidee-

'Her brow was overhung with coins of gold,

Which sparkled o'er the auburn of her hair.

In her air

There was a something which bespoke command, As one who was a lady in the land;

Her eyes were black, her cheeks' pure dye Like twilight glowing still with the set sun.'

"Instead of glowing the word is rosy in the poem: I "venture to alter it for the picture. I would rather have "found a quotation from a more respectable poen than “ ' Don Juan,' but it suits the picture so perfectly that it " would be impossible to come nearer to its impression. "I will beg the favour of your exhibiting this head in the "British Gallery this winter. She would not do in "Somerset Honse, among " the pale umripened beauties of " ' the North' - who, by-the-bye, are much paler and whiter" 
" in English pictures than in nature.* This was not the " taste of Reynolds. Some French author says, " La chalemr " "est le cachet du coloriste - it is at least one of the essen" "tials." Later he says to Mr. Harman, "From all I can " hear, I am considered quite distinct from the established " mode of Painting in England, although they do me quite " as much justice as I can desire. I think it would be easier "for me to abandon the art than to be a white painter."

* Haidee was erentually exhibited in the Royal Academy in 1831. The Duke of Wellington, after having looked round the rooms, was heard to say, pointing to Haidee, "There, that's the best picture in the Exhibition." 


\section{CHAPTER V.}

Visit to England,-Reception at Royal Academy.-Bruges.-Antwerp and Rubens.--The Hague and Rembrandt.-Cologne and Meister Stephan.

-Reflections from Ehrenbreitstein.-Frankfort.-Leipsic.-Berlin.German Society.--Dr. Waagen.--Dresden and Correggio.-Mnnich and Cornelius.-Verona, Mantua and Giulio Romano.-Venice.-Venetian Art and Architecture.-Florence and Fra Angelico.-Rome.-Turner.Rev. Hngh Rose.-Election as R.A.-Leaves Rome.-Copies pictures at Venice.-The Country of Giorgione, Bassano, and Titian.--Settles in London.

It was in March, 1828, that Mr. Eastlake left Rome for a visit to England, taking Lausanne and Berne on his way. He was enchanted with the Swiss scenery. Thence by Neufchatel, Pontarlier, and Besançon to Paris, where the modern Exhibition was still open-"a great treat. I saw the old Gallery too by special permission." Arriving in London, he was welcomed by his excellent friend, Mr. Harman, who, after so long a separation, did not recognize him. He now entered upon the privileges of his new membership, and was officially received by the President and Council with a most complimentary address from Sir Thomas. He attended at the varnishing days and saw his picture of the Pilgrims excellently hung. A visit to his brothers at Plymonth, and to his aunt Pierce, still living, engrossed most of the time. Returning to London only for a week he breakfasted with Mr. Rogers-was introduced at Holland House, and found many Anglo-Roman friends solicitous for his society. But his heart was set upon visiting the chief galleries of Holland and Germany and he quitted London and its many attractions towards the 
close of June. His route was determined by Sir Joshua's tour through Flander's and Holland, and he made it a point to follow in his steps and verify as far as possible his descriptions. At Bruges he began that careful examination of pictures, accompanied with copious notes, and copies of monograms and ciphers, which not only greatly enlarged his comnoissemship but laid the foundation of his especial study of the materials for a History of Oil Painting. With all his peculiar refinement of taste he was too large and sound in his feeling for art to exclude or undervalue any form of excellence. And we must remember that this true catholicity was a thing unheard of then, when the world still partook of the ignorant exclusiveness which had prompted the well-known saying of Louis the Fourteenth. From this onesidedness even Sir Joshma had not been fiee. Charles Eastlake in this respect was greatly before his time, and some of the ensuing remarks by him, thongh now no longer novel, are added to show how far he outstripped the then prevalent tone of criticism.

The Van Eycks and Memlings at Bruges immediately enlisted his most just enthusiasm. "These pictures at "Bruges, by the early Flemish Master's were the first " of the kind I had seen. Their richness and depth "astonished me; hard and minute as they are in many "respects, these master's have the last richness and power" "of oil or varnish." The Van Eyck, too, still remaining at St. Bavon-'The Adoration of the Lamb'-was perused with a kind of astonishment. "It is a marvellous "work, like the labour of a life; such a style must have " made painting appear more of a wonder than it is now." Antrerp, Brussels, and Mechlin gave him all the glories of Rubens and Vandyck; and Rubeus especially-always an object of his deepest homage-was carefully analysed and described. At Antwerp the great master's chair stood at the end of the Museum under a glass case, as it does 
still. It had then a garland upon it, a remmant of a fête shortly before given to Rubens' memory. "There could " have been small matter for merriment. The spirit of " the glorious painter has entirely left those who pretend " to honour him." These words are happily not so unreservedly appropriate now as they were forty years ago.

From Antwerp he passed by steamer to Rotterdam, where he conld not hear of a single collection. Thence by Delft to the Hagne. Here he luxuriated in the Museum and in several private collections, and Teniers, Jan Steen, Jordaens, Hobbema, Ruysdael, with all the smaller celebrities of Dutch Nature and Art unadorned, received each their due and discriminate tribute. At Amsterdam the greatest of Dutch painter's, of whom he was one of the most ardent worshippers, engrossed his attention. "Sir Joshua seems " to think lightly of the great picture by Rembrandt, with " portraits of the Arquebusiers ("The Night Watch'). I " confess I prefer it to all the Van der Helsts, fine as they " are. Nothing can be more sumy than this picture. The " portraits of five citizens of Amsterdam are more praised by "Sir Joshua; both pictures are in his roughest, most fear" less manner, yet highly and truly finished in their effect. "The shadows are not transparent, or rather not left, for he " seems to have made a clear ground and used it when he "wanted one. The shadows of middle darkness are, how" ever, often heary-when lighter again, as in the girl's " head carrying the fowl, they are beautiful-gemmy and " transparent. This head, with the hair, is of the softest "and richest (sfumato) kind, and impasted fearlessly and " diversely, as if he had not succeeded at first."

Of "The School of Anatomy," then belonging to M. Roos, and about to be sold, he says: "It has been cleaned " too much; the glazing is gone from some of the heads, " and from the dead body. The lights on it are cool. "Nothing, as Sir Joshua says, can be finer and truer than 
"its colour. It is a much smoother and more finished " picture than those now in the Museum." . . . . "All " the excellencies of Painting-the specific style of Painting " -are to be found in these schools. What cause can be " assigned for the superior" genius of these nations? They " are now sunk; but we have never risen so high; for "Reynolds, Gainsborough, Wilson, Hogarth, and a few " more, camnot match the hosts of Flander's and Holland."

Later he says, "I began by seeing Flanders and Holland "from Brussels to Amsterdam, and I camnot now admit "that Rubens and Rembrandt are inferior to any "painters."

Nor was it only the picture galleries which attracted him. The booksellers' shops divided his affections, in some measure, with the pictures. Holland is rich in old artliterature, and various additions to his valuable art library were made which found their way to Rome.

From Amsterdam he proceeded by Arnheim and Nimeguen to Cologne, where, like Albert Durer, three centuries before him, he procured the opening of the altar picture by Stephen of Cologne in the Cathedral. "The colour of these "pictures is not good, nor are the characters so full of " nature as those of Tan Eyck and Memling. They are " most interesting for the costume; there are specimens of "armoul" (more plate than chain), arms, head-dresses, \&c. "One of the Three Kings kneeling and praying is fine and " earnest in expression."

In the old Musem at Cologne, he was struck with the figure of the Angel, in an early picture of the Agony in the Garden. "The angel, who appears in the air, is counting "three with his fingers (a beautiful outline in the Journal "accompanies this), and this explains the action of Michael "Angelo's Jonas. The angel reminds Christ of his certain "resurrection in three days, and "the sign of the Prophet "Jonas' has its meaning in the same number." 
Arriving at Coblentz in the evening, he went up Ehrenbreitstein: the view thence overlooked suggested some reflections on the treatment of landscape which are worthy of careful consideration in our own day. Admiring the scene of river, bridges, and town, stretched out before him, he writes: "And yet a vulgar or unskilful artist might "fail altogether in meeting the impression made upon the " mind. A literal imitation of many things which were " risible, and even somewhat prominent, would have de" stroyed the charm of the scene. This truth, common as " it is, is connected with some very important principles of " art which are not so generally recognised. In represen"tations which depart altogether from Nature, and belong "to the regions of Poetry, those details are suppressed " which would betray the convention of the idea. In very "abstract representations of Nature, also, all circumstances "which would diminish the grandeur of the impression "are omitted. There is evidently, then, a necessity for" "generalising in every branch of art; - there is always much " to be omitted, and the omission of useless or pernicious "detail only makes the whole-the ruling idea-more " impressive and distinct. In the imitation, therefore, of "Nature, the great question is-what is the general cha"racter of the impression received? and next, what are its "chief canses? If these are duly ascertained, the opposite " circumstances which counteract the impression are easily " detected and suppressed, or only hinted at. It is not " uncommon to find persous who have the truest feeling "for the poetry of a scene (and even artists are among "them), who in imitating the same scene on paper" or" " canvas, make such things prominent as destroy the very "feeling they experiencerl. The translation of a feeling " into picturesque analogous representation is thus an art " of itself." . . . . "There can be no doubt that our" " memory of nature is composed entirely of general ideas, 
" and art must be generalised to meet this idea of beanty. "The mere copying of Nature in detail is not only objec" tionable because it does not correspond with our im" pression of her, but it immediately suggests the feeling " of its inferiority to Nature, and the more so the closer" " it is. Thus an imitation so close as to produce illu" sion to the eye, would be precisely that which would be " considered defective, because whatever remains unac" complished,--sound, motion, \&c.,-would be felt to be " wanting."

I may here mention his favourite aphorism: "The de" finition of a pure style is that it should suggest no want."

From Coblentz to Mayence, and thence, by hiring a cabriolet, to Frankfort, where Dannecker's Ariadne was seen and criticised. "Not well composed or extraordinary " in any way." Then to the Musem, where he notes some fine Ruysdaels, and some remarkable early German pictures, but without names. "I remarked that they uniformly give " black its abstract force, with little or no light. The " attention to the character of the colours is often their "only excellence."

After Frankfort, by Gelnhausen and Hanau to Gotha and Weimar, which were quickly seen. Schiller was recently dead, Göthe absent; the last romantic whim of the Grand Duke, to be buried between them, was then the small town talk. Thence to Lützen, and so to Leipzic, where the battle was still the topic, and where he found the Elster "not so broad as the Plym." Here Baron Speck's fine collection of pictures, which he revisited thirty-five years after, was inspected. He now approached Berlin, and travelled with a man "who was an author and " Doctor of 'Theology, although he smoked, talked nonsense, " and worse, and was very hard upon an old Jew with "whom he occasionally spoke in Hebrew. The Germans, " at least many of them, acquire their immense knowledge 
"as some men in England acquire money-it is merely for" "itself, and does not make them better or happier." At Berlin he fell into society which gave him characteristic impressions of the philosoplyy and infidelity of this "over"thinking people, who make the perception of beanty an " imnate faculty, but, by a singular contradiction, consider " notions of virtue, and even of the being of a God, the effect " of prejudice not admitting of proof." Among these acquaintances, was Schopenhaner, the so-called philosopher, the son of Joanna Schopenhaner. With this German he held discussions upon his favourite theme of the Laocoon. "Among the many opinions on the expression of the Lao" coon, and the reasons why he was not represented crying " out, was one lately noticed in a periodical as the worst, if " the most original; namely, that with the action of the "arms the figure would appear to yumn. Schopenhauer" " told me that Hirt (a writer on art) and Göthe in different " ways maintained that when the stomach is so drawn in as "that of Laocoon is, from the bite of the serpent in his " side, it is impossible to cry ont. Winckelmamn, on the "other hand, we know, says that the mind of Laocoon was "too great to give way to physical suffering. Lessing " himself urges that the sacrifice of the literal truth was "made for the sake of beanty. ('This is his judicions " and careful mode of applying his theory: the difference " between sculpture and poetry was what was uppermost " in his mind.) Before Schopenhaner gave me his orn " opinion, I thought I would try the application of my " theory, viz., that it was a sufficient objection that the " sight of an open mouth in marble would make one feel " that sound was wanting. He stared at me, and said " it was his very idea-that he objected to the open mouth " because it would exhibit the means of doing what was "not done (namely, the uttering sound). In my own " humble opinion, the revealing a want is the great objec- 
"tion, and it is the consistency of imitation which makes " the Greeks so perfect."

At that time the Giustimiani Gallery had been acquired in Berlin. It contained little that our traveller considered gemuine. "But the picture of pictures, one which has been " added to the original Giustiniani collection, is a small "scene in a courtyard by De Hooghe. A man in a black " short coat aud hat, with some red about his legs, sitting " at a table in the open air with another man; a woman "standing, and a child seated at the passage door throngh " which you look into the street. The light is so general " that the shades are almost imperceptible, and the colours, " particularly the black, red, and white, tell finely. The " shadows are everywhere transparent, and the light silvery "and magical. It is not a highly finished picture, but its " truth is perfectly astonishing, and no stronger proof can " be produced of the superior effect of powerful local colour" " and imperceptible light and shade. I would take this "picture before any other in the gallery. . . . In the " old palace there is an immense collection of pictures; a " thousand that cannot be hung, and perhaps as many that " might be unhung." The taste of the King was exemplified in his treatment of two English portraits, one of the Emperor Alexander, by Dawe, a most wretched performance, which was hung in a place of honour; and the other a fine portrait of the King, by Lawrence, which was put ont of the way: and that not from any modesty, (for plenty of his portraits by very indifferent German performers hung about,) but because his Prussian Majesty did not understand how a king should have any shadow under his nose.

Mr. Eastlake, however, succeeded in seeing the Solly collection, which forms the staple of the present fine Berlin Gallery, of which he gives full notes. The remaining compartments of the famous Van Eyck, of which he had seen 
the centre at Ghent, were also seen and admired. The late Dr. Waagen, subsequently one of our most esteemed and attached friends, showed him this collection by favour, for it was then only preparing for the gallery, and the gallery for it; Dr. Waagen being occupied in compiling his admirable catalogue.

The next gallery was Dresden, where he chiefly deroted limself to the analysis of Correggio's qualities. I again transcribe some of lis notes. After remarks of a technical kind, interesting only to painters, on the peculiarities and perfections of the great master's execution, he says: "But some of the expressions are not wonderful: the "Madonna is like a hundred others, and the bystanders "have nothing remarkable. It is in the angels where "Correggio's genius appears; one or two of the heads and "actions are exquisite. In composition this painter is not "so pure as Raphael; his expression, too, does not (so " much) grow out of his subject. It is always the same " - arch, smiling, gay,-but the contrast of this and his "fantastic, graceful actions, with solemm, slumbrous, " mysterious chiaroscuro, concur to make up an impression " of the roluptuous. In sacred subjects, again, where such " a feeling is counteracted and balanced, the pleasing rague "impression experienced is rery peculiar, and belongs to "this painter alone. The action of the heads in some " of the lower figures is quite like him, but affected and " ummeaning.

" There is one great difference between the softness of "Correggio and that of MIurillo, Rembrandt, Reynolds, and " others. Correggio carried the softness of gradation to " the ntmost extreme in his flesh, and in any one thing " compared with itself; but the figures often detach with the " most iron hardness from what is different from them. In " the St. George, and in the St. Sebastian, the Madonna is "relieved, almost to inlaying, on a light sky, and the out- 
" lines of limbs in other figures, coming on objects totally " different from them, are rery defined. The degree of "relief seems proportioned either to the real difference of " things, or to their importance in the picture. It happens " that the Madonna in both these pictures is the principal " figure, and the abrupt effect of her hard, dark outline on " the light sky is useful in attracting the attention first. "The contrast, again, of this extreme hardness with the " imperceptible blendings of the light and shade on all the "flesh, has the happiest effect. The separation of things " really different in their nature, and the increased union of " that which is really one, is always agreeable, because " characteristic; but the degree of hardness-the quantity " of cutting outline-is the point where schools differ."

From Dresden he visited Nuremberg and Augsburg. At this latter place he began to see the Swiss and Tyrolese momtains, and felt "inexpressible delight at being so near" "Italy." Then on to Mumich, where he made acquaintance with Cornelius, and passed a peculiarly fair judgment on that so-called "German Michael Angelo." "Cornelius' "works have a grand conception and a sort of con"densation of the spirit of his subject, but still, some"thing which tells better in words than in painting. I "have observed that Germans and Italians are always "glad to harangue and describe their pictures, and their" "works naturally look better and more interesting while " this commentary is going on. It would be wiser if they " calculaterl what effect these pictures would have when " they are left to tell their own story, which they must do "sooner or later. This is an important consideration for "an artist. The colour in these frescoes is absolutely " below criticism, the expressions vulgar and exaggerated, "and the forms by no means pure. A grand com"position and grand general conception are the chief " merits-the only merits. The fallen state of criticism 
" and knowledge of art here is very perceptible. The "painter is landed by his brother artists (with some few " exceptions), and, of course, the connoisseurs and the " public follow. The truth will only be known fifty years " hence. Amidst such a world of error in all these moder"r "schools it is absolutely necessary to define the end and "means of art, and to follow them conscientiously, fear"lessly. . . . Cornelius has departed from nature "without rising to a general idea: mamner", caprice, vul"garity, and ugliness are often the consequence. His " designs for" the Loggie of the Pinacoteca are rery profound " and full of meaning, even to the smallest ornaments; but "who will ever see this? Small paintings, overhead, in an " open passage-surely a waste of thought! The agreeable " impression on the eye should be the main thing. Mean"while this depth of thought excites admiration among "those who judge of paintings by their descriptions."

I will not dwell on his notes on the contents of the Gallery of the then Schleissheim collection, and on that of the Duke de Lenchtenberg. The large and important Memlings, then at Schleissheim, made a deep impression on him. "In the famous picture, called the Seven Joys of " the Virgin, the whole history of the travels of the Wise "Men from the East are given. On the left, where the "Nativity is represented, the two figures lineeling and "praying outside-one in black, the other, younger, in "green-are among the most beantiful things in painting."

From Mrmich he passed on by the beautiful Weller See, and so by Botzen, and descended into his beloved Italy on the 21st of August; though immediately paying the penalty of the mal-govermment then all orer that "rich and royal" land, for he had to hurry to reach Verona before sunset, on account of the dangerous state of the neighbourhood. Here the grand amphitheatre and the glorious works by Paul Veronese divided his attention. "The amphitheatre 
" is very grand; the inmense unbroken circle of steps and " some figures (which I happened to see) at top, breaking " this beautiful line, had a most striking effect, such as one " cannot see in the Coliseum which is r'uined."

At Mantua he is very outspoken about Giulio Romano. " Most of Giulio Romano here is decidedly bad, particularly "the room of the Giants, which are ill-drawn monsters. "Even the rocks are nnnatural. The side opposite the "windows is the best, the figures are more distinct. But "the room before this, where the great Polyphemus is " (a noble figure), is full of fine things. But I could not "help regretting here that ceiling painting should have " been so misunderstood as to attempt deception by fore" shortening. If really well done such figures can never "look like human beings, whom we never see in such " attitudes. And if we imagine a God we never see him "foreshortened, but exhibiting the best of nature. The "Apollo in the small room, showing the sum rising and the "moon setting, is disagreeable, and uselessly indecorous. "All that should be concealed is displayed, "et preterea " ' nihil." " Diana is draped, but it is a shapeless mass, and "you have the pleasure of looking under horses' bellies to " have poetical visions awakened. Nor is the colour of a " nature to do away with other objections, and in the room " of Polyphemus, however poetical the subject overlead, the " colour is black and most unpleasant, and the foreshorten" ings so violent that the only feeling excited is that of " wonder at the skill of the artist in this poor and object"less particular."

Passing through Vicenza and Padua, seeing and noting all, he at length reached that spot on earth, which, next to Rome, interested lim most. He was now in Venice. "It " surpassed all my expectations. But for the people and " the absence of all gaiety, riches, and activity, the place " itself is exactly what it might have been four centuries 
“ ago. St. Mark's looks older than all history, and has an " uncontl mixture of Gothic, Roman, and Arabian taste" ugly, chivalrous, and mysterious. T'he impression made " on the mind by St. Mark's, the Dncal Palace, the tower, "the square, and all the well-known buildings, is most " peculiar, and not to be experienced elsewhere in Europe. "The half barbarons splendour and solemn remote " character of the two first must be seen to be felt. But " the principal canal, with its palaces, and with its varieties " of buildings, from the earliest Gothic to the Palladian, " is like enchantment. Every evening I went the whole " length of this canal in a gondola, and never shall I forget " the effect of those exquisitely coloured buildings under " the last soft light of the Alpine sunset."

Venice and Venetian painters were too intimately connected in his mind and eye for him not to perceive how each told the other's tale. He saw 'Titian and Giorgione in Venice, and Venice in them, in a mamner peculiar to himself, and formed a theory upon the more hidden springs of Venetian art, which he often alluded to in our frequent visits to the City of Water's. He first remarked that the daily spectacle of the summer sun, setting behind the Friuli mountains, accounted "for" the golden and mel" low horizons behind blue mountains, which are so com" mon a feature in the distances of Venetian pictures. This " is first seen in the very early painter's, and is also a proof " of their looking at nature, as fit for imitation, most in " the evening; when shadows are soft, when local colours " are hence not destroyed by violent opposition of light " and shade (which may make two distinct colours of an " object that is really one), when all is warmed by the glow " of the sky and atmosphere, and when, which is also an " important consideration, the observer of nature is most "likely to be at liberty, after the labour of the day, to look "at her appenrances." 
Further, watching the effects around him with his everreasoning eyes, he felt that there was something too in the very mode of locomotion, which was in itself an advantage, and peculiar to Venice;-namely, that an individual borne along on a smooth surface of still waters in the tranquillity and isolation of a gondola, was more able and disposed to observe the advancing and recerling effects of objects around, than if engaged in the more nsual acts of walking, driving, or riding; - that the figures passing before him, instead of increasing the busine of ordinary movement, were seen under the same placid conditions (or, if rowing, in a unifor'm motion) which also gave opportunity of watching the same figure at different distances. "I am " quite convinced that one main cause of the excellence " of the Venetians, in a large imitation of nature, was the " simple circumstance of their being able to make use of " their eyes without even the trouble of walking about. "This advantage is very great, and to be met with " nowhere else. Added to which, the backgrounds and " accompaniments to figures thus observed are of a nature " to exhibit their characteristic colour in the most forcible " manner. In the great canal a glowing gondolier is seen " in his white shirt-sleeves against cool, neutral architec" ture, and with the greenish water aromd him-contrasts, " all tending to light up his sumburnt limbs and face " to a fiery depth;-but this intense glow is not seen in " its largest and truest appearance till the figure is at " a considerable distance. This effect is undoubtedly the " truest idea of a colour, whatever the colour may be, " because it is that which the memory most retains. Titian " and Giorgione went all lengths in imitating this general " effect, not only in sumburnt figures, but in fairer ones. "The ruins of the frescoes on the Fondaco de' Tedeschi," although perhaps even the ruins are vestiges of retoucherl " figures-deep and flaming as they are, are not more so 
"than figures sometimes appear with due contrasts as " described above. . . Titian used the same exaggerated " scale in large altar pieces, which were to be seen at good "distances. The Assumption, Peter Martyr, and the "Frari picture, are all of this class; and the St. Sebastian " at Rome; but Giorgione was the great inventor of this " noble violence, or rather first carried it to perfection."

Also, as regards the architecture of Venice, he remarks that it is not its ancient and very extraordinary character which is perpetuated in Venetian pictures, but rather that of the later Palladian taste. "Panl Veronese saw the " motives of his architectural backgrounds in Venice, but " it was precisely in his time that some of the more " modern, more Italian, and less Gothic of these buildings "were designed. His own pictures are indeed enough to " show what was the taste of the Sansorinos of the day, " and doubtless many of their designs were executed only" " in the magnificent backgrounds of this painter. . . .

" It must be confessed a more elegant style of architecture " could not be selected than these Palladian porticoes, most " fit for Italian, and exactly expressive of a modernized Roman "feeling; like the spirit of antiquity waking after its subjec" tion and suppression, and throwing off Gothic influence in " taste-some would say unfortumately-and regaining its " own, just as much as the nation regaimed itself; that is, " very imperfectly; but yet so modified and adapted to its " new self, as to have a decided character. The Painter's " of the highest era of art in Venice are strictly Italian. "The Germans had a marked influence on the sculpture " and arehitecture of Italy, at Pisa, Assisi, amd elsewhere; " but here, where the neighbourhood of Germany would " seem to involve dependence on its taste, the Venetiaus " seem never to have been much influenced. The East " is visible in St. Mark's, in the grand and flowing " robes of the old Venetian nobility, and in the gorgeous 
" attire of their women. The first Venetian painters, the "Vivarini, Carpaccio, Cima da Conegliano, \&c., are like " their Italian cotemporaries; and Giovanni Bellini is so "great in his finest works as to bear a comparison with " any of the precursors of the Augustan age of painting in "Rome or Florence."

"The costume of the women in Venice is the same as " far as regards the white mantle for the head as it was “ centuries ago. Their faces have depth, richness and soft " shade from it. Many of the veiled heads of the Madonna " in Venetian pictures have precisely the shade, the colour, " and the distant breadth of these heads as one remarks " them when details are no longer perceptible. One con" sequence of looking at this distant, largest effect of " nature is that expression is lost by it, although the " general air of beauty is improved; and as expression and " nicety of form are qualities only to be appreciated near, " so they have less to do with the essentials of beanty, " which reside in general proportion and general colour. " Correggio and Raphael are perhaps the painters who best " succeeded in uniting what can only be seen near with " what can only be seen at a distance."

While making these general observations Charles Eastlake threaded his way about Venice, by water and land, in a way few have done. With Zanetti in hand here, as with Sir Joshua in the Low Countries, he did not overlook a palace or a church among the legion of both in Venice, and every picture they contained was carefully noted. It was here his eyes were first opened to the charms of Gio. Bellini. He writes to Mr. Harman, "Sir Joshua speaks "of him, as compared with Titian, with too much con" tempt, because he was a high finisher. But Gio. Bellini " was a great painter; with beauty, expression, often fine " arrangement, and a glowing colour, which, it is said, he "latterly increased from seeing what his scholars dared. 
". . . Perhaps the imperfection of immaturity is " always more pleasing than the imperfection of decline."

After Venice-lis notes on which would alone form a rolume-he mored on to Ferrara, and so by Bologna to Florence. I must not detain him here, except to observe that, as in Flanders, his largeness of feeling, and devout, unprejudiced purity of taste enabled him to do justice to masters on whom few then bestowed a glanee, or remark. He had found out the fine action and expression of some of the Giottos at the Arena Chapel at Padua, and here he fastened on a painter previously so little cared for, that the fine specimens of him levied (and it is difficult to see why) by Napoleon's agents from Florence, had neither been deemed worthy to be exhibited in the Lourre, nor to be reclaimed by the Italians. This despised painter was Fra Angelico, "the most interesting to me of the " early painters, and whom I would place above Giotto. "In a series of subjects from the New Testament, and, " abore all, in the Last Judgment, there are beanties not to " be found elsewhere, and equal to the purest feeling of the "Van Eycks and Memlings." He writes later from Venice (1830) with significant foresight, "I am afraid there is too "little interest in England for early pictures which throw " often so much light on the leading characteristics of "schools of art. A most valuable collection was formed "by an Englishman some years since in Italy (the Solly "Collection), and since sold to the King of Prussia. I saw " the pictures at Berlin, and very curious and interesting " ther are. I hope the historical view of art will not be " ultimately overlooked in our National Gallery. I think " much of the essence of Yenetian art is to be understood " by tracing it from the beginning."

He reached Rome in the millle of September, and was shortly after joined by Mr. Turner the landseape painter, who resided with him for several weeks, working in the same 
studio. Mr. Eastlake was soon engaged on several pictures -one of them, which is engraved and has become a popular composition, he thus describes and comments on. "It is "a Banditti subject, with larger figures than I have yet " used for such subjects. A Contadina family, prisoners " with Banditti; relief coming, unseen by the party, in the " distance. I mention this picture to you (Mr. Harman) " becanse I have painted the landscape after my own feeling, " however little $u p$ to it. I wish you to see if you like the "style, for it is what I consider, with deference, the sort of "landscape that accords with elevated subjects. It is here "merely an accessory, and simple in composition, but it " may serve as a specimen." 'Those who know the picture, or even the engraving, will l'emember how fine the landscape in this instance is. "Mr. Turner used to laugh at me for "my fastidionsness (he began several pictures and finished " three, long before I had done one), but in these things " men are differently made. I have by this time found out " what my taste in art is, and the degree of finish and other " qualities which, to my feelings are indispensable. . . . " I distinguish, to my own conscience, between a sincere pur" suit of truth, and the attacking the opinions and feelings of " other's, as Haydon did. By degrees I am arriving at my own " convictions on the style of art I profess, and I shall not " be satisfied till I feel that I am free from the influence of " the age and its taste. I do not condemn them, but I have " a longing desire to be free from prejudice; and I feel a " sincere aiming at truth to be so pleasing in itself that " even success (although most likely to follow from it) is a "secondary consideration. . . . . It is thus a real " pleasure to me to arrive in my own way at the conclusion " that the English school of painting is the most rational " now going; and however the English artists at home may " differ from each other in their style, yet, as they all come " under a general character, I am not afraid of being too 
" unlike what is in fashion." This opinion had been formed by his recent visit to England. He adds in another letter: "I am disposed now to think that the excellences which "belong to and characterize Painting are more understood " in England by a few men than anywhere else. Of these " it is my opinion that Tumer is the first-without going "the length of admiring all his extraragancies-though his " rery exaggerations have opened my eyes to his real merits." At this time he kept up a correspondence with his friend $\mathrm{Mr}$. Rose, who in the interim had become a fellow of Trinity College, Cambridge. By his encouragement Mr. Eastlake had embodied his ideas on the philosophy of the Arts in a paper destined for the "Quarterly Reriew," which Mr. Rose undertook to correct for the press. Mr. Lockhart, then the editor-than whom a more enlightened critic on art did not exist-cordially approved of it, and expressed his desire to receive further contributions of the kind. Mr. Rose writes from Cambrilge, May 23, 1829 :-_" It is a most " admirable paper. I have allowed one of our first people " (Professor Wheweli) here to read it, and he quite agrees " with me." It was already in type, when the fastidious writer forbade its publication. He embodied parts of it in his rarious Reports of the Fine Arts Commission, which, in their turn, were also partially embodied in the rolume of Essays edited by Mr. Bellenden Ker.* To return to $\mathrm{Mr}$. Rose; this gentleman adds, "You will afterwards be "able to collect and correct your essays, and gain the " reputation you deserre by publishing them witl your own " name. I hope hereafter to live to see and hear you in " Reynolds' chair, delivering to the students instructions "which will, I think, mite to his beautiful feeling and " refined taste more philosophical depth and truth."

* "Contributions to the Literature of the Fine Arts." The only paper by Sir Charles in the "Quarterly Review" is a "Review of the Life of Raphael." 
On the 10th February, 1830, Mr. Eastlake was elected full Member of the Royal Academy. His "Pilgrims in sight of Rome" may be said to have giren the last impulse to the choice of the Academy. He now felt it an obligation to return and reside in London. It was indeed high time that the move should be made, for his health suffered greatly from the climate of Rome, or rather from the climate under the conditions of indefatigable labour and rigorous sechusion to which he condemned himself. No man ever put a lower estimate on his own merits and powers. No man was ever (as far as an inflexible self-respect permitted) more genuinely, more touchingly humble. It never occurred to his single-hearted and over-anxious nature that he possessed excellence of any lind. He never tasted the sweets of an elate feeling; he needed another to be proud of him and elate in him; to presume to speak the prajseful and happy truth, all wrapped up in so tender and reverential an affection that he could as little doubt the praise as the love, and to speak it thus over and over again.

It was with great unwillingness that he turned his thoughts towards England. Not that a foreign residence had unanglicized him-quite the reverse; but he had a dread of the difficulties and conditions of a London professional life-a dread owing chiefly to his entire diffidence of himself. He now writes to Mr. Harman. " When I sent home what "I fancied would be my last Banditti picture, I looked "forward to following the art as I wished, and to soon " becoming more strictly an historical painter. I have " now to make the experiment of living in England, and " how my historical or poetical dreams can be realized " there I know not. . . . . Long ago I never thought "I should get attached to Italy for any other reasons " than what made it attractive to Poussin-that is, for its " antiquities and classic materials. I have since loved it " more for its landscipe and modern costume; and I have 
"lastly lored it most for its being the country of Titian, "and still containing what we admire in his pictures, not "forgetting landscape. . . . . . I hope now soon " to move off to Venice and take another, but I hope " not a last look at the part of Italy that interests me " most."

After finishing his Diploma picture-his first version of Hagar and Ishmael-he mrooted himself from Rome, after a residence there of fourteen years, and reached Tenice at the end of July. Here, with his esteemed friends, Miss Leach and her brother, Dr. Leach, and Signor Incoronati, a Roman gentleman of the highest character and acquirements, since then a resident in England, he occupied the apartments in the Nocenigo Palace, formerly hired by Lord Byron. Having on his former visit, two years before, completely mastered all the sights of Venice, he now deroted his time to making small studies from various pictures by Titian, Giorgione, Panl Veronese, \&c. Some of these are in oil, others in water-colour; the latter chiefly from the Manfrini collection, where he could only execute these studies-perfect as they are-in his sketch-book, standing. 'Two copies from the now destroyed Peter Martyr by 'Titian -one in oil, the other in water-colour-are perhaps the most faithful records and adequate witmesses now existing of that great work.

He remained in Venice above two months, and then started on an exploring trip into the country of Giorgione and Bassano-with the works of Ticozzi and Maniago in his hand-of which he has left a careful journal. He began at Treviso, where the grand altar picture in the Cathedral by Fra Marco Pensabene-the history of which is still shrouded in mystery-attracted his unqualified admiration. He describes it at length, and characterizes it as " a very noble performance." He also examined the so-called Giorgione, the Dead Christ in the Tomb with boy angels, in the Monte 
di Pietà-now ascribed, principally by himself, to Annibale Carracci. It was in a wretched condition; and that fact and the violent foreshortening "rather astonishing " (where successful) than pleasing," marle him reticent in praise. He then proceeded to Castelfranco, of which he remarks: “In the more southern parts of Italy, " the name of any town or village with the adjunct of "Castello, at once implies an elevated site; and it is with " some disappointment that one discovers that Castelfranco " is in a very flat plain, with no other elevation than the "ramparts of a square fortification, from which it takes its " name." He here visited the altar-piece, known as the one indubitable work by Giorgione, of which the S. Liberale in armour is said to be the painter's own portrait. * He mentions here a painter comparatively unknown to fame, Ponchini, (called Bozzato) " by whom a fine picture behind the altar"The Descent into Limbus-was executed : an artist who " might have rivalled Giorgione and Titian, but who, having "lost his wife, as the story goes, retired into a monastery." He also traced the vicissitudes of the old Barbarelli mansion through various possessors to the family of Rainati, in whose hands it remained in 1830. "But the " Rainati house has nothing now of former days about it; " the southern front is morem Italian; and there is a snug " garden round it, bounded on two sides by the shattered " brick walls of the old fortress, to whose ruins and ivy the " eye turns with pleasure. If anything can influence the " taste of a painter (after he has practised his art) it must " be the scenery by which he was surrounded in early life. "Giorgione lived at a distance from mountains, and saw " them mingle with the sky. The plains to the south and "west towards Vicenza and Bassano, bounded by distant

* The small study for this figure by Giorgione-but with the helmet in the hand instead of on the head-was left by Mr. Rogers to the National Gallery. 
" and not very bold hills, remind one of the broad vague " backgrounds which accompany his figures, as in the altar"piece in the church here: whereas, in Titian's distances "the forms and details of the mountains show that he was " acenstomed to see them near. . . . . On approaching "Bassano, which is separated by the Brenta from a wall " of mountains, the sun sank suddenly behind this natural " rampart, leaving a considerable tract of the country in " premature twilight, while the plains towards Vicenza and "Padua were still warmed by the more gradual decline of "day. To one who looks for the physical causes of a " painter's style, this long soft twilight and the depth of the "valley of the Brenta camnot but seem comnected with the " solemn, dark, but sparkling and clear manner observable " in the best pictures of Giacomo da Ponte. There is " another particular" in which this painter may be more " clearly traced, although a trifle. Bassano has ever "been, and is still, filled with manufactures of copper" "vessels. The metal comes in a prepared state from "Venice, but it is beaten at Bassano, and the principal "street contains several such workshops, with abundant "specimens before the doors. . . . . Although there " is no defending the painter for introducing these uten" sils on almost all occasions, it must be confessed their " colour and their sparkle are singularly picturesque, and " in so dark a style as Giacomo's, some such svegliarino " was absolutely necessary. To find sparkle and warmth " together" was too great a temptation-in short, it is only to " be regretted that copper" vessels are so vulgar-their colour " is, in some situations, more beautiful than gold. In "Giacomo da Ponte they unite the beanties of the metal " and the gem."

"The road from Bassano to Belluno, throngh Feltre, " begins to be picturesque at the latter place, which is "within the mountains. 'The road is nearly flat as far" as 
"Asolo, five miles from Possagna, Canova's birth-place, " and where his church is. Feltre is beantifully situated; " and from thence to Bellumo the road lies again in a "wide rich plain between the mountains. Belluno is on " the Piave, whose gravelly bed is sometimes half a mile " broad, which in winter is entirely filled with the moun" tain torrent. There is always water enongh to float " down varions articles of commerce from the mountains " to Venice, where of course the raft is broken up and sold. "Among the things thus supplied to Venice from these " mountains above Belluno are turpentine, ragia," (resin) " and olio di abezzo; and it happens that the materials " nsed by the Venetian painter's not only abound in the " mountains near, but particularly near the comntry of "Titian. And, besides these gums, it is worth noting " that in addition to the fir and the larch on the higher "groumds in the district of Cadore, the only tree which " is at all common in the neighbourhood of the villages, " and in the warmer valleys, is the wahnt-tree-the oil "produced from that nut, as well as that from linseed, " are both common articles of commerce throughont the "mountains. The road from Belluno to Pieve di Cadore "follows closely the course of the Piave: a few miles " past Belluno the mountains shut in, and there is room " only for the river and the road, and now and then for" "some villages. It is only in the immediate neighbour" hood of Pieve, which stands very high, that the houses " begin to take the German instead of the Italian form " in the roofs. In all the compositions of landscape by "Titian, those, for instance, engraved by Le Fève, pro" bably from drawings, the houses have the German form, " and hence doubtless indicate Alpine scenes-the rely " rugger ontlines of the mountains indeed prove the same. "At Cardore and in the neighbourhood the mountains " correspond in form with the boldest introdnced in 
"Titian's pictures; and the castle of Pieve di Cadore " (which was destroyed so lately as 1796) now in ruins, "finely placed on a rocky eminence, is undoubtedly the "original of the background" (believed to be by Titian) " in the picture of the Bacchanals by Bellini in Rome.* "The point of view is the first appearance of the rock " coming from Perarollo to Pieve; or in the same line “" nearer the village called 'sotto Castello,' whose wahnut trees " would form the foreground, and almost complete the scene. "There is, howerer, one great liberty taken by Titian, " and by all the Venetian painters in their landscape, "and the German painters who may be considered the " masters in that respect of the Venetians (as they were " particularly of Titian) may be included. They unite the " most rugged and romantic forms of the higher Alps, as a " distance, with the richness of the foliage of the plains. "But where these mountains appear so distinctly as those " masters represent them, the fir-tree is the principal " clothing even of the foreground; and a fir-tree is never "introduced-wisely enough-for its form is too peculiar. "There is a wood engraving by Boldrini of a composition "by Titian of a naked Vemus and Cupid, and fir-trees " appear behind. This is the only instance I remember. "The conoscenti of Pieve are certain that Titian must " have come by Belluno to Pieve in his almost annual visit " to his birth-place; but certainly the landscapes in Le "Fèvre's collection do not correspond with any scene in " that road, nor with the scenery for many miles round "Pieve. The forms of the houses in these prints corre"spond with those in the higher district, where the winter " snow renders acute roofs necessary; but the scenes are " richer in trees, and they probably belong either" to Friuli " or to a mountain road from Maniago to Pieve, now "scarcely practicable, it is said, on horseback. . . .

- Now at Alnwick Castle. 
After inspecting the wrecks of Titianesque pictures, at Zoppè, Domegge, Calalzo, Rizzuos, Valigella, Tai, Vodo, Vinigo, S. Vito, Posali, \&c.;-maltreated specimens, possibly once valuable; "for the changes which fine pictures may undergo from time and repainting are incalculable,"he adds;

"In this wild mountain district, where the inhabitants " seem to live miserably, it is interesting to find so many " memorials, bad and ruined as they are, of the name and " taste of Titian. Nor was he the first painter who sprang up " in these ungenial scenes. A gigantic St. Christopher out" side the church at Domegge, tolerably well drawn, belongs " to an earlier period, and Tolmezzo beyond Auronzo, in a " still wilder country, gives its name to an early painter of " the Friuli school. It has been already stated that there " seems to be no resemblance between the taste of Titian in " landscape and the real scenes of his native place, except "the bold momtains, the Alpine roofs, and perhaps the "walnut-tree, whose solid and massy foliage recalls the "dense manner of the master in trees. The demand for " the decoration of the churches, without, as well as within, " must have been the chief canse of the existence of the arts " here; and, in the Friulese school, as Maniago observes, " the largeness of manner which is the chief characteristic, " arose from the broad and necessarily rapid practice of " fresco painting. These villages are all very inconside" rable. Pieve itself has not more than 500 inhabitants, " but in most, even in those least accessible, there are men "of talent and learning. Not long ago a very fine library "was bought at Borca (beyond Vodo) from the family " 'di Luca' by the Abbate Zelotti of the Barbarigo Palace, "Venice."

These extracts are sufficient to show the nature of his wanderings in these wild parts. Few, perhaps none, even in these easy times have so closely explored these regions, 
in which painting once flourished more like a flower of the field than of the garden. Conegliano, Pordenone, Udine, Cividale, S. Daniele, and the beautiful Gemona, were now successively visited; after which he crossed the barrier into Carinthia, and made his way to Salzburg and so to Munich. Here he resolved to devote what he felt would be his last opportumity of freedom to visiting Viemna, where, following his usual system, he compiled a thorough guide book of all the pictures worth noting in the various Viennese galleries.

He arrived in England in time for the distribution of prizes; and for the lecture at the Royal Academy on the 10th December, on which occasion he went through the forms of admission as full member, and was immediately appointed one of the in-coming comcil. He then took a convenient house in Fitzroy Street, realised the privileges and conrenience of the Athenæum, and, welcomed and appreciated by friends, old and new, soon felt himself no longer a stranger in his native country.

Thus far I have endearoured to trace, and chiefly by means of his own modest and undesigning testimony, the life and character of my distiuguished husband-distinguished not more by the class, range, and ever-diligent development of his fine powers, than by the purity and uprightness of his life. He was now jnst thirty-seren years of age as he finally made his home in London. What has been told sufficiently shows how entirely he was qualifiedhow conscientiously, howerer unconsciously, he had graduated-for the high offices connected with art, which he had subsequently the honour to fill; also how richly he merited the personal deference and respect with which he was regarded by all good and just men. I say this advisedly, because the public are well aware that he suffered at one time from that injustice from which all finer spirits are seldom entirely exempt. This injustice simply regarded those matters of opinion on art on which there is no fixed 
code; but on which, ultimately, his own knowledge and opinion came to be regarded as the decisive authority of an absolute master of the subject. On higher points, even malevolence found nothing to assail in him. I have alluded to this passage in his listory in order that my further silence respecting it may not be misinterpreter. To use his own words, "Defences are often as bad as attacks."

With this period, though his more active and public career begins, yet its very publicity leaves me less occasion to dwell largely upon it. It has been my object, as first stated, to give a record of a mind of an analytical and logical character, rarely accompanying a passion for art; a mind which would have left its mark on any form of intelligence to which he might have applied his powers. My task is therefore nearly completed, for the rest of his life, though comprising those years which were the whole of life to me, neither furnishes the same materials nor requires the same exposition. It is the first half of a man's career which tells what the second half will be, however diverse the two in outer circumstances. 


\section{CHAPTER VI.}

Principal Works.-Changes in patronage of Art.-Society, and thoughts upon it.-Schemes for promotion of Art.-The Lawrence Drawings. The National Gallery.-Fitzwilliam Mnseum.-Life of Raphael.Göthe's Theory of Colours.-Kugler's Italian Painters.-Conversation.-Sydney Smith.-Macaulay.-Nassau Senior.-Mrs. Jameson.Mr. and Mrs. Grote.-Earl of Essex.-Sir Robert Peel.-Cornelius.Fine Arts Commission.-Appointment as Secretary to Fine Arts Commission.

There was little personally eventful in Mr. Eastlake's life rluring the first ten years after his return to England; though one occurrence deserves mention, which may be said to have inangurated him in a civic scene, which was the presentation to him of the freedom of his native city in January 1832. This period, however', from 1830 to 1810 , was the most productive in works of note by his hand. A picture commenced in Rome, but not exhibited till 1831, "Peasants returning from labour," life-sized half-length figures of an Italian Contadino, his wife, and infant, shows the ripening effect of his visits to Venice, and, from the subsequent rally in colour made by the English school, would probably excite even more almiration now than it did then. In 1833, the subject of "The Greek Fugitives," was exhibited ; in 1834, the "Escape of Francesco Carrara;" in 1835, another version of "Pilgrims in Sight of Rome;" in 1836, two narrow, long pictures of the same subject; in 1837, "Greek Captives;" in 1838, "Graston de Foix before the Battle of Pavenna ;" in 1839, "Christ blessing little Children ;" in 1840, the "Salutation of the aged Friar." These were 
pictures which occupied centres on the Exhibition walls. They were accompanied at the same time by many works of less importance. All the portraits he executed belong to this time; some, like that of Sir Stephen (then Mr.) Hammick, being treated with an madorned dignity which places them high as examples of simple nature; while in certain portraits of ladies, where the subject permitted, he gratified himself, as well as the fair sitters, by attiring them in a fancy costume. In this way, Mrs. Bellenden Ker appeared as an Italian Contadina, with a basket of grapes; * Miss Bury, with long hair and a white lily; Miss Johnstone (niece of the Dowager Comntess of Essex), also as an Italian peasant. These "fancy portraits," as they were called, were greatly admired, and would have filled his hands with this class of occupation, had he not pertinaciously refused to devote limself to portraiture. With these also appeared smaller subjects, such as "La Sregliarina," "The Martyr," (St. Sebastian), \&c., and now and then a single head, like that which had attracted the Duke of Wellington's admiration. One circumstance which, though a tribute to his art, has detracted somewhat from the full honour due to it, was the demand for repetitions of the same subject. Thus there exist five pictures of "Pilgrims in sight of Rome," namely, 1st, executed for Duke of Bedford; 2nd, for Earl Grey; $\dagger$ 3rd and 4th, for Marquis of Lansdowne; 5th, for Mr. George Vivian. A 6 th of the subject is a bona fide copy from the picture belonging to Lord Grey, made for Mr. (now Sir Francis) Moon, the printseller, for the purpose of engraving. These five pictures include two, in every respect, distinct compositions: the original of the one being that executed for the Duke of

* I am permitted to say that Mr. Bellenden Ker has bequeathed this picture to the nation.

+ In Lord Grey's picture one of his own grandsons-a son of Lady Elizabeth Bultecl-served as the model for a boy in the foreground. 
Bedford-of the other, that belonging to Earl Grey. In the first, the Pilgrims are arlvancing from the left; in the second from the right; while the replicas of each composition display varieties in colour, arrangement, and back. ground, sufficient to constitute originality. So far indeed from these replicas being repetitions, they afford remarkable examples of the impossibility inherent in the true painter to repeat himself.

A change which has proved of great importance to British art dates from these years. The patronage which had been almost exclusively the privilege of the nobility and higher gentry, was now shared (to be subsequently ahmost engrossed) by a wealthy and intelligent class, chiefly enriched by commerce and trade; the note-book of the painter, while it exhibited lowlier names, showing henceforth higher prices. To this gradual transfer of patronage another advantage very important to the painter was owing; namely, that collections, entirely of modern and sometimes only of living artists, began to be formed. For one sign of the good sense of the nonveau riche consisted in a consciousness of his ignorance upon matter's of comnoisseurship. This led him to seek an article fresh from the painter's loom, in preference to any hazardous attempts at the discrimination of older fabrics. Thus such gentlemen as Mr. Sheepshanks and Mr. Vernon, who were the first founders of this class of collections, contended, and often with success, for the possession of fine modern pictures, with patrons of rank and distinction.

The many applications for Mr. Eastlake's pictures, made as soon as they appeared on the Exhibition walls, showed the increasing demand for works of this class. One inquiry which he records with peculiar gratification, was addressed to him for his picture of " Christ blessing Little Children," from a locality not redolent of patronage of art-namely, from Thames Street. A reference to the catalogue at the 
end will show how this class of competitors took the lead in patronage as time went on.

Occupied as he was with increasing commissions, executed with increasing fastidiousness, he was yet, during these years, drawn largely into society; renewing many pleasing ties which had commenced at Rome, and forming others which were of great value to him. Among those with whom he was most intimate may be reckoned Mr. Harman, his early patron and friend, and his excellent wife; Mr. Rogers, and his sister Miss Rogers; Mr. and Mrs. Bellenden Ker; and the renerable Earl of Essex; all of whom showed the genuine nature of their regard for the object of this memoir, by soliciting the pleasant society of his brother William, whenever he risited Fitzroy Street. Nor may I omit Mr. Charles Jones, of Gower Street, Solicitor to the Admiralty, and long comnected with the Plymouth Eastlakes in Admiralty business, at whose hospitable table there was always a corer for him; or Mr. Brockedon, "the immortal Brockedon," as Leslie calls him, with the noblest of hearts, and the grandest of persons, who never failed a friend in any emergency or trouble. To these may be added those whom in later times he called " $m y$ kind and constant friends, the Carrick Moores, and Horners," with other representatives of talent and worth, always ready to appreciate lindred qualities in all new-comers.

At the same time he found it very difficult to combine the habits of social life with that standard of industry which alone satisfied him. From time to time he gare it out among the circle who kindly sought him, that he intended "to turn hermit for three months." He did so in as strict a sense of the word as the interruptions of London admitted. The delicacy of his health, and the sensitiveness of what he called "the finer fibres," rendered it the more necessary to provide against hurry or anxiety in fulfilling commissions; and ret no one estimated the advantages of mixing with the world 
more justly. He reasoned thus to his brother William. "I go into society as much as I do, often against my will, "because I know from experience that it is good for my " moval health. If I could unite this medicine (as some " people do) with habits of application and industry in the " day to the extent I wish, I should be in an enviable situa" tion. A certain tranquillity always results from inter" course with polished people; all painful and hmmiliating "feelings are banished from their circle; their world is beau" tiful and happy; but internal quiet is derived from the con" scionsness of duties fulfilled. 'Those who unite the two " must be, I think, the happiest of human beings. The fact " is, the mion of the two requires greater energy than soli" tary study. In my own case, if I find that I am unequal to " it, and knowing, as I do, that my profession is my chief ob" ject, I must relapse into the dull student I have often been." Mr. Bellenden Ker, especially eager for the advance of art, and not less for that of his friend, and energetic in all he took in hand, was foremost in the genial appreciation of his brush, his pen, and his society. For this gentleman Mr. Eastlake decorated a room in a house near the Pegent's Park, in the Pompeian style,* as a specimen of the ornamentation compatible even with small English interiors. 'The walls were prepared white in flat oil, and the materials used in painting were flat transparent oil. This room attracted much notice, and, considering the bad reputation of the atmosphere in which it has existed for nearly thirtyfive years, it remains wonderfully unimpaired.

In these year's society rang with the subject of Reform, and, after his secluded life at Rome, the ardours of politics and strife of parties were watched with quiet amusement as well as deep interest by one as unused to such themes as

* No. $2 \pi$, Park Road. The work was entirely executed by Mr. Eastlake, with the exception of the animals forming part of the design, which were by the hand of Mr. Iswry, the animal painter. 
he was unprejudiced. Yet while he writes to his brother, "I am only a Whig because you and George are," and "politics in general do not interest me further than as " they affect your welfare," it would be unjust not to own that his predilections were of a liberal kind. These prevalent ideas of Reform and Progress were not confined to politics. The Fine Arts shared in the general stirring tendency, and it is curious to observe how soon he was fixed upon as the right person to promote and direct such movements. A proposition to: found a professorship of art at the London University, seems to have been contingent on his acceptance of the post, for, on his declining it on two distinct occasions, in 1833 and 1836, the scheme fell to the ground. A request to give a series of lectures on the principles of art, at the Royal Institution, he was also unable to comply with. Mr. Ewart's motion for the establishment of Schools of Design for the improvement of manufactures, was the first public step taken to assist the development of a certain class of art. In this scheme Mr. Eastlake took great interest; and a plan suggested by him, and communicated to the Committee by $\mathrm{Mr}$. Bellenden Ker, himself on the Committee, was approved and adopted; but when invited by Govermment to undertake the direction of the then new scheme, with a salary, he remained firm to his conviction that no painter had time to spare, for duties of this character, from the exercise of his art. He subsequently, in 1836 , consented to be one of the Council (unpaid) appointed by the Board of Trade for the new Schools, but he took no other part in the movement.

Meanwhile he had been induced to become a member of the Useful Knowledge Society, founded in 1833, by Lord Brougham, then Chancellor, by whom, and by Mr. Bellenden Ker, he was proposed. He joined the board on the understanding that he was only to be referred to, in Mr. B. Ker's works, "when any great Gordian knot of art was to be 
"severed." Whereupon he was immediately consulted and set to work regarding the design for a seal and the purport of a motto, best calculated to represent the character of the Society! He retained this supposed sinecure seat at the board for a twelvemonth, during which time he contributed articles on the Fine Arts, on the Bolognese School, and on Basso-relievo, to the Penny Cyclopredia, one of the Society's publications. He had already witten the lives of Leonardo da Vinci, Correggio, Murillo, Canova, and Reynolds, for a work called the Portrait Gallery, published by Mr. Charles Kinight.

It was owing to his connection with this Society, and chiefly to the fact that a principal member of the Cabinet was at the head of it, that Mr. Eastlake was at first encouraged in the arduous but fruitless attempts to convince the Govermment of the policy as well as duty of securing Sir 'Thomas Lawrence's collection of drawings by the old masters. This is a chapter of sufficient importance in the history of art to deserve a detailed notice here. By the will of the late President, dated June, 1828 (Sir Thomas died in January, 1830), directions were given that his collection of drawings by the old masters should be offered to George IV.- to the Trustees of the British Museumto Sir Robert Peel-and to other known collectors and patrons, for the sum of $18,000 l$. If not purchased by any of the above-named, the collection was to be purchaseable as a whole for 20,000l.; Sir Thomas having, as he calculated, spent about 40,000l. in its acquisition. All negotiations with the parties specified having failed, and no private purchaser coming forward, a proposal to raise the requisite funds by subscription, and to keep the collection entire, was mooted. On this occasion, the Royal Academy, in January, 1831, voted a contribution of one thousand pounds, on the condition that the collection should be placed either in the British 
Museum or National Gallery, and made accessible to artists and the public. Sir John Soane is reported to have followed the example of the Royal Academy by the promise of another thousand pounds; while Mr. Eastlake, in his private capacity, pledged himself to contribute a hundred pounds. This project also failed, and finally the Messr's. Woodburn, through whom Sir Thomas had principally formed the collection, became its purchaser's.

We trace part of the history of this affair in Mr. Eastlake's letter's, which first notice it in March, 1834, and thus perceive the early date at which he, in some respects, originated views which have since been commonly adopted.

"I have lately been examining (of course only at night) " the Lawrence drawings;-Keightley, the managing exe" cutor, being, as I once told you, an old school-fellow of " the Charter House, and having given me full opportunity " to see them. I gave some facts relating to the history of " their collection to Brockedon, lately, to send to some " paper", and the article appeared in the Morning Hercld. " Woodburn, the person who first collected and sold most " of them to Lawrence, has, within these few days, offered " $16,000 l$. for the collection. He means, if he gets the " drawings, to offer them still to the nation for $20,000 l$., "and if obliged to sell them piecemeal, he says he will "make $30,000 l$. of them. I am very anxious that this col"lection should be preserved and publicly seen, and the plan " would be to have a hundred frames in the National Gallery, " and change the drawings occasionally. Among them are " the original studies by Michael Angelo and other's for "figures in pictures in the National Gallery itself.* I saw "Sir John Soane about this a few days ago, and wrote to "Mr. Morrison," (then an active M.P., and a collector" of

* Among the Michael Angelos were several sketches for the figure of Lazarus in the "Raising of Lazarus" by Seb. del Piombo; also of the figure in M. Angelo's Dream. 
pictures) "who has just been here, and having come from "Lord Althorp, he was not exactly in a humour to think " favourably on the subject, and says that Lord Althorp " would laugh at it. Lord Althorp, however, sets lis face "against the arts altogether, and said once that if he had " his way he would sell the National Gallery, and have no" thing of the kind. Fortunately there are not many who " agree with him. I have told Mr. Morrison that if the " drawings were in the National Gallery it would at once " compete with the Continental collections, for there is no" thing like them in number and excellence elsewhere. He " thinks Lord Sandon" (now Earl of Harrowby) "would be " a proper person to bring the subject before Parliament, or "Sir Mathew Ridley; to both of whom I will speak. Ker, " of course, is at work. He has asked me if a Committee " is moved for and obtained, whether I should have any ob" jection to be examined in the House of Commons on the " subject. I saic no; but I fear, for the sake of the clraw" ings, that it will hardly come to so promising a state of " things. . . . Returning to the Lawrence drawings, I " begged Morrison to use his influence, and to mention " them to any members who could bear the subject. I said " there was no objection against the purchase of this collec" tion, that was not equally as good an argument against " the existence of the National Gallery at all."

Shortly after the date of this letter Mr. Bellenden Ker" called the attention of Lord Brougham to the subject, who declared his wish to inspect a selection of the drawings if the executor would entrust a portfolio to him, and if Mr. Eastlake would describe them. "I attended therefore on Good "Friday (March, 1834,) at two o'clock at the Chancellor's " new residence in Great Stanhope Street. Lord Lansdowne " and his daughter, Prince Talleyrand, Lady Sefton, Lord "Moncrieff, and several others were present. 'T'he best "place for seeing the drawings was given to Talleyrand; 
" and the conversation was conducted in French on his " account. I had more to say of course than anybody, as "I was asked questions about every drawing; and even "while talking with the Chancellor the conversation was " still in French (and at least I beat him there) which was " amusing enough. After having seen all the selection, " Talleyrand said: 'Si rous n'achetez pas ces choses là, “ 'vous êtes des barbares,' in which the two Cabinet " ministers agreed."

This agreement, however, of the powers that were, led to no result. The next steps taken were by the Messr's. Woodburn-steps equally calculated to forward the wishes of Sir Thomas Lawrence, and to promote the private sales which their own interests required. They opened ten successive exhibitions, each lasting a month, and each containing one hundred specimens of a particular master or masters. These continued during two seasons.* The Rembraudt drawings were immediately sold in a lump, and thus the integrity of the collection was first broken up; and by the close of the tenth exlibition the Clandes, 'Titians, Albert Durers, the three Carracci, and Julio Romano were all disposed of in unbroken sets. Still, there remained a splendid collection, which included the Raphaels and the M.

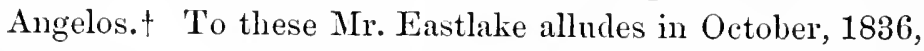

* In May, 1835, One hundred by Rubens.

\begin{tabular}{|c|c|c|c|c|}
\hline July, & 1835 & " & ” & Vandyke and Rembrandt. \\
\hline August, & 1835 & $"$ & $"$ & Claude and Poussin. \\
\hline January, & 1836 & ", & ", & Parmegianino and Correggio. \\
\hline February, & 1836 & ” & " & $\begin{array}{l}\text { Leonardo da Vinci, Julio Romano, } \\
\text { Primaticcio, and Perino del Vaga. }\end{array}$ \\
\hline March, & 1836 , & ", & " & The three Carracci. \\
\hline April, & 1836 & $"$ & " & $\begin{array}{l}\text { Fra Bartolommeo, Andrea del } \\
\text { Sarto, Zucchero, and Pol. da } \\
\text { Carravaggio. }\end{array}$ \\
\hline $\begin{array}{l}\text { May, } \\
\text { June }\end{array}$ & 1836 & " & $"$ & Albert Durer and Titian. \\
\hline $\begin{array}{l}\text { June, } \\
\text { July, }\end{array}$ & $\begin{array}{l}1836 \\
1836\end{array}$ & , & " & $\begin{array}{l}\text { Raphael. } \\
\text { Michael Angelo. }\end{array}$ \\
\hline
\end{tabular}

+ Previous to the exhibition of the Raphaels hopes had been entertained 
when he says, "You are perhaps aware that some months "ago the Treasury nominated five Commissioners to fix " the ralue of the Lawrence drawings-namely, Howard, “ Hilton, Wellesley, Josè of the British Museum, and " myself. This I heard of at the time, but have heard no " more since, and now Woodburn, the possessor of the "drawings, is so tired that he is at last determined to sell "them piecemeal. I believe he gives Spring Rice" (then Chancellor of the Exchequer) "but a week more to decide. " Woodburn himself has nominated five Commissioners" of whom Lord Vernon, Esdaile, and Richard Ford are " three-the latter is a great comnoisseur."

In 1838 the Messrs. Woodburn opened another series of exhibitions from their almost inexhaustible stores-first of Rubens and Vandyke, and then of Raphael again-and now they fulfilled their resolution to offer the drawings piecemeal for sale. A large portion accordingly passed into the possession of the King of Holland, and of the chief private collectors in England and the Low Countries. Still there remained a considerable number even of the Raphaels and M. Angelos, with other masters, and to these Mr. Eastlake

that the Trustees of the National Gallery would have recommended, at all events, the purchase of that master. They declined to do so, unless for a price based on that named in Sir Thomas's will. It was in vain, however, to suppose that such favourable conditions could be maintained by mercantile owners, and this after the lapse of a considerable time. The price now demanded by the Messrs. Woodburn for 180 drawings by Raphael was fixed by a committee of gentlemen, to whom allusion is made above, at 12,000l. Meanwhile the leading journals vied with each other, at every fresh exhibition, in urging this opportmuity of enriching the national stores of art. Finally, after the tenth exhibition-that of M. Angelo - a memorial from professors and amateurs of the fine arts was addressed to the Lords of the Treasury, entreating that the Raphaels and Michael Angelos might be secured. Among the arguments used was one which might have been deemed irrefutable-viz., the example of the purchase of the Elgin marbles-once so stoutly opposed, but since recognised as a signal honour and advantage to the country. This memorial was signed by nearly 400 individuals, including names highly distinguished for knowlcdge and taste. 
refers in July, 1840: “On Saturday last I was at an evening " party at Lord Monteagle's and spoke to him, Mr. Rogers, " and Lord Lansdowne again about the purchase of the " Lawrence drawings for the nation. (They are all Trustees " for the National Gallery.) The only excuse for renewing " this business, the negotiations respecting which have " repeatedly failed, is that the Messis. Woodburn have " come down very much in their demand. In consequence " of suggestions from Lords Monteagle and Lansdowne, I " have induced the Woodburus to address a letter to Mr. "Wellesley, Mr. Josè, and myself, with their reduced price. " The trio, of which I am one, were appointed by Govern" ment some time ago to give an opinion as to the value of " the drawings. This is the excuse for addressing us, and, " having received their application, we have this week " addressed the 'T'reasury once more, enclosing Woodburn's " new proposition. These papers will be handed over by " the Treasury to the Trustees of the National Gallery, " who meet on Monday next. I think the two noblemen " and Mr. Rogers, to whom I have spoken, will be "favourable."

'The finale to this rather melancholy story is, that the Treasury remained inexorable, and that such of the Raphaels and Michael Angelos as remained were finally purehased by the University of Oxford in 1845 for 7000 l.*

It is easy now to wonder at what appear's the shortsightedness of Government, public bodies, and even of private individuals, as displayed in the history of this remarkable collection. For there can be little doubt that had a few wealthy persons combined for its purchase, they might, as with the Orleans Gallery, have retained the choicest portions and repaid themselves with the sale of the residue. But while choice and in most instances indubitable works were thus pertinaciously declined, an instance, on the other

* 40e0l. of this $r 000 l$. was ccntributed by the late Earl of Eldon. 
hand, may be quoted of an over-readiness on the part of the Trustees of the National Gallery to lay out the public money, without what would now be deemed the commonest precautions. At that time, it must be remembered, there was an almost entire absence of connoisseurship in this country. Fine pictures by the old masters, of all schools, were purchased and highly valued by the English nobility and gentry, but these were usually so attested by their previous history that no niceties of knowledge were required respecting them. The purchasers and eliminators, for instance, of the Orleans Gallery, just referred to, suffered no qualms of doubt as to whether real Raphaels and Titians had fallen to their share. The contents of that gallery needed little guarantee beyond the fact that they were such. This rery certainty may eren in some measure be said to have retarded the progress of true connoisseurship, for works admitting of no question invited no analysis. Mr. Rogers was a singular instance of a man who thought and felt for himself in matters of art, and though he had small pretensions to those subtleties of linowledge only obtainable by long experience-the acquirement of which, while it must be always rare, is indispensable now-yet his taste was so fine that he made fer mistakes in his private selection, and, as a Trustee of the National Gallery his rote was alwars in harmony with the true interests of the public. The 'Trustees also, though endowed with unquestionable authority to purchase pictures, had but rare opportunities of exercising those powers, while such acquisitions as they did make-that, for example, of the two grand Correggios in 1834 -though of the highest valne, needed no real discrimination on their parts. But the time was now approaching when only knowlerge could decide as to the genumeness of a picture, and when no consciousness of ignorance had as yet suggested any diffirlence in such matters. 'The following transaction reflects ton much credit on the arlmirable sense 
of Sir Robert Peel, as well as on the knowledge of the history of art possessed by Mr. Eastlake, to be omitted here.

Mr. Eastlake wites, May 3, 1841: "I mentioned that "the Trustees of the National Gallery invited me to "give an opinion on a soi-disant Raphael which they "have some idea of purchasing. The proposition to " consult artists before making these purchases was made " at the last meeting of the Trustees for the first time, " and it was made (so Sir Martin Shee tells me, who " was present) by Sir Robert Peel. The President of " the Royal Academy, Howard, Etty, Callcott, and myself "were named. To-day the Trustees meet, and having " only seen the picture the day before yesterday, it was "only yesterday that I sent in my report. I am afraid " it will be rather humiliating to them (entre nous), but at "least it will show that Sir Robert Peel was right. I " have been able to give the whole history of the pic"ture, for it is described in more than one work, and "this kind of lore (with the help of the artistic library "which I have by degrees collected) I have, as you lnow, " at my fingers' ends. I have given them my own opinion, " confirmed by a mass of evidence, dates, \&c., which I "think must show them that they need a little en"lightening on these matters. On Saturday I so far let " out my own opinion that I observed to . . . . . at " the Academy dimner that the picture was certainly not by " Raphael. 'Not by Raphael!' he exclaimed. 'Bless " "me, we never had any doubt abont that! the only " "question was what it was worth, and we wished you to " "say whether it would be an acquisition as a specimen of " ' the painter.' They had believed some spurious story " about Raphael's having painted the picture at a certain " time and place. I have given the clearest proof that "all this is unfomder-in short, my only fear is that I " have given them too strong a dose. I have, however, 
"said, withont pretending to judge of the price, that it " would be an acquisition to the Gallery as the work of the "painter to whom I attribute it (on grounds amounting "to proof"). When Sir Robert Peel made his proposi"tion, . . . . , who piques himself on being a judge " of Italian art, said he thought it would be imposing too " much trouble on the members of the Academy to consult " them. Sir Martin Shee, with his usual readiness, said " the very object of the Academy was to promote the " interests of the arts. There might be many cases of " doubtful pictures on which I could not have pronoumced; " and, above all, in which I might not have had docu"mentary evidence at command. It is particularly for" tunate in support of Sir Robert Peel that I have been " able to furnish the information I have sent. What the " other painters have done I don't know, and of course I " have not communicated with them, but I am very certain " that none are in possession of the historical facts I have " adduced. This letter is full of boasting, but it is true; " and as I have sometimes been thonght to have wasted " time in acquiring this kind of knowledge and, I may add, "spending a good deal of money gradually in collecting " materials, it is a satisfaction to know that all this tells " at last."

An official letter from the Secretary (Col. Thwaites) acknowledged the information supplied, and the picture was not bought.*

It was not long before this that he went to see 'a Titian' which had been mentioned to him, and which was about to be raftled for at 6000l. After a careful inspection he pronounced it to be "a fair copy, not even done by a Venetian painter." Mr. Seguier afterwards confirmed his

* The work in question was an unfinished Holy Family by Fra Bartolommeo-purchased several years later by Mr. Thomas Baring, and now in his gallery. 
judgment. The instances in which he stood between spurious pictures and would-be purchasers were innumerable. These are only mentioned to show how rare was such knowledge out of the mere dealer class at that time.

It may be safely said that, though Mr. Eastlake as yet occupied no responsible position, ret the sense that he was an anthority in various departments of the arts very widely prevailed. In 1837 he was requested to give assistance in a matter where a painter is not generally inroked-namely, in the design for the sculpture to occupy the pediment of the Fitzwilliam Musem at Cambridge; a building then in comrse of erection by his friend Mr. Basevi. He accordingly supplied the design of the figures of the Muses, superintended their execution by Mr. Nicholl, and finally (in June, 1840) their erection. Before this he had been included in a meeting at the British Museum, "called by " the Architects' Institute to ascertain whether the Elgin " marbles were painted or not. Faraday, who was present, " has I think proved that the brown stains on the marble " never could have been paint. It had been asserted that " the columms and all in the Parthenon were painted."

In June, 1810, an article by him entitled the "Life of "Raphael," appeared in the Quarterly Review. The now well known work by Passavant, on the life and works of the great painter, gave occasion to this paper, which is a fair specimen of the writer's variety and thoroughness of knowlerlge, and of the manner in which he turned it to account. Viewing Raphael as the central figure, at a period umparalleled for historical and antiquarian interest and artistic fertility, there is hardly a name in art or literature which led up to the great master-a sorereign, a locality, or a form of art connected with him-to which he does not impart fresh interest. Seldom hare the life and works of one man been treated within the compass of an essay 
with such fullness - with what a painter" would call "such a "sense of a whole." The article attracted notice, and many compliments in the society in which he moved, for it was generally assmmed to be his; but the praise which gratified him the most was that of the late Earl of Aberdeen, for whose work on the Principles of Grecian Architecture he entertained great respect.

In 1840 also his translation of Göthe's Theory of Colours was published. He had intended at first "to make a " selection of such of the experiments as seemed more " directly applicable to the theory and practice of Painting." Indeed, he was anxious to have it understood that it was rather for this than for the salie of Göthe's theory that he undertook this translation. In his own words, to his brother, 27th May, 1840, " the theory, right or wrong, was the theory " of the Italians at the revival of letters, and is closely " comnected with the practice of the Italian painters. This " is what I have endeavoured to show in my notes." If it " is asked whether it was necessary to give all the work to " prove what I undertook to prove, I answer that it is less "responsible for" a translator to give the work entire, -it is "also more just to the author." This translation was dedicated to Mr. Harman. It was reviewed in the Edinburgh Review of October, 1840, by Lord Brougham, in a manner sufficiently complimentary; though at the same time, he sought to expose error's which the translator had repudiated. and failed to perceive the specific object he had in view.

Mr. Eastlake was now tempted to turn his attention to Kugler's Handbook of Italian Painters, October 1840: "I " mentioned sometime since that I had declined to edit a " translation from a German work on art. I have, lowever, " since consented, as the translation was very defective; and "I feel it a duty to lend my assistance in putting good "and historically correct things before the public. This

* These notes have been published in the "Contributions." 
" now takes up all my spare time." The work was published in the following year, and no book has been more popular or more serviceable for the purposes of instruction to travellers in Italy. The preface to it by Mr. Eastlake is rich in learning and philosophic thought, and has been inclucled among the "Contributions."

By this time our painter had been elected a Fellow of the Royal Society, which he entered before the death of its President, the Duke of Sussex; and he soon became a member of the Stirling Club,-the Literary Club-The Club,-and other's. He also visited Woburn, Bowood, Cashiobury, and Drayton Manor. In his letters to his brother William, a rumning commentary is kept on the chief characters and events of the day-such as might serve to beguile the lonely hours of an invalid, himself well competent to take part in what was going forwarl. This commentary is of too private a nature to lay before the public except in such an instance as the following, and where those mentioned are favourite public property:- "Novr. 7, 1837. "Sydney Smith was full of his clever hits the day I met " him. I could not help thinking that there conld hardly " have been a match for him in the golden days you "alluded to. It is not the greatest names that make the " most brilliant society. In the lines 'Smith how to " "think, Burke how to speak, and Beauclerk to conrerse,' " of the whole catalogue there is but the last who, it seems, "was an agreeable talker. Sir Joshua himself was as deaf " as a post. . . . . . . In the instance of the "celebrated society you alluted to-Garrick, Reynolds, "Johnson, \&c.--I have no doubt we are deceived by the "greatness of the names into a notion that the con"versation was always sustained and brilliant. Johnson " could not be an agreeable companion, though, like "Colerilge, he was privileged as a lecturer; and at the "fanmons dinners at Sir Joshna's there was as much 
"nonsense, bad pums, and loose talk as elsewhere. "Such a man as Sydney Smith rould, I think, have "eclipsed most of them. He is the specimen of " " jorial wit I would select from those I have seen. As a "polished wit and bel caprit perhaps Luttrell has seldom "been surpassed, and his manners are perfect. Then "for knowledge in matters of taste, miversal aneclote "and wit, with the greatest tranquillity of manner, while " he keeps your attention always alire, there is no one like "Rogers. Rogers and Luttrell are of course rivals, but "some months since, when Rogers had the Duke of Wel" lington and other very distinguished people to dine with " him, he selected Luttrell as fittest to help to entertain " them. Sydney Smith often reminds me of my father, and "I often wish two such persons could have met. Sydney "Smith is also about the same bulk, and shakes with "langhter in the midst of his own bon mots. The other" " day he had some business at the Mansion House, and while " talking, without knowing who the people all were, some "person handed a paper to him, on which was written, " "The gentleman you are speaking to is the Lord Mayou" " 'Elect.' He said he instantly thought of the Roman " ambassador to Carthage who was suddenly shown an " elephant, and, to the disappointment of all, betrayed no " emotion. Talking of the absurdity of continuing the " service about the Gunporder Treason, Lord John Pussell " happened to say, 'not that I approve of Guy Fawkes,' " upon which Sydney Smith kept the table in a roar for " some minutes by praising "such candour." "

Macaulay's powers of conversation also obtain a page of a letter. Mr. Eastlake had been dining at The Club, where the members are supposed to consist of the best conversers of the day: "Macaulay, though always worth listening to, " is such an indefatigable talker that few of the rest coul? "say much. He is nerer long on one subject, but goes oft" 
" on the slightest hint or association, especially if suggested " by another. The effect is curious-if you turn to a neigh" bour to make or listen to a remark, and then return to "Macaulay, expecting to recover the thread of his obser" vations, he is on a totally different subject. The Dying "Gladiator-the Mogul Empire-the Nerra of T'Tibullus"the last Travels in America-Mathematics-the style " of Ovid-the date of Virgil's death, and innumerable " other subjects, interspersed with quotations, follow each "other without pause."

It is agreeable to record his impressions of a few other notabilities-including some happily with us still. Mr. Nassau Senior he met for the first time at Bowood, in 1837: "He adds the qualities of plainness and affability" " to the profoundest learning and the most agreeable con" versation. The conversation somehow turned on Homer. "On my spealing of the accuracy with which Shakspeare "had drawn the Homeric characters in Troilus and "Cressida, Senior" said with his usual plainness that he " was hardly acquainted with that play; but, on my" " allucling to various inciclents and expressions in Homer, " to my astonishment he, in erery case, quoted the original "lines."

A mention of Mrs. Jameson in 1840, on first making her" acquaintance, will be welcome to the many who remember her with affection and respect: "Mrs. Jameson is writing " an account of all the picture galleries in Lonclon. She " is a rery pleasing person, and with all her cleverness, " is as much a woman as she ought to be. I go to her" " occasionally at Notting Hill, and while I take care not to " interfere with her opinions" (on painters), "I now and "then assist her with facts. I was to have gone to her "last Thursday week, but she was then staying with "Mrs. Grote, and instead of Mrs. Jameson's going home "to receive me, Mrs. Grote invited me. Mr. and Mrs. 
" Grote live close by Belgrave Square. Buth she and her" "husband are, as far as I have seen, extremely clever, " eloquent people, and very fine in person; both tall, well " developed human being's, with minds corresponding."

It may be inferred that the mind here attempted to be pourtrayed was characterised by a gentle respect for women, which won for him in tum the mixture of deference and confidence due to a true knight. Speaking of Leslie's Life of Constable, which interested him deeply, he says, "The letters of Miss Bicknell are models of good sense " and good taste. How much excellence lies hidden in " women!" And again later, "Women are sooner reason"able than men, and if they have less reason they have " more taste and good sense."

While he reflected thus on society and recorded facts belonging to the busy hum of cities, he was also feelingly alive to scenes of a very opposite kind, more comnected with his brother William's life than with his own. Shortly after the introduction of the pemy stamp he writes: "I have " received all your letters - that from St. Mary's Hill, " written, it appears, with mind, but not quite with frame " at ease, was particularly interesting. No letters are so " agreeable as those which are written as a substitute for" "conrersation. This could hardly happen when postage "was so dear. It was not worth while to sit down and "write flying thoughts at sixpence a page. Some philo"sopher, a few years hence, will date a change in the strle " of correspondence (at least among the classes who never" "enjoved franks) from the reduction of postage.

"I saw the cloudless sky, the garden, the sycamore tree " and seat, and, alas! you yourself 'labouring against the " easterly wind' without your having taken any particular "trouble to describe all this. It must be good for you "sometimes to sit and muse in the country when wind " and weather are propitions. In a note borrowed from 
"Dr. Young in Mant's Bible (begimning of Genesis) the " tranquillity of a garden is pronounced to be favourable " to refiection and peace. I believe most people will con"fess under such circumstances a secret consciousness, not "felt in rooms or towns (solitude even supposed), of a "spiritual influence. The Past and Future appear with a "pleasing solemnity-the memory of the Dead and the " absent returns without pain-the evidence of the never" failing care of Providence orer Nature consoles, and the "individual, mite as he is, amid the rastness of heaven "and earth, feels that he too is seen and remem" bered."

It is a pleasing duty to record the exceeding kindness of an aged nobleman, whom I may reckon among Mr. Eastlake's intimate friends. It was in the hospitable house of the late Earl of Essex, in Belgrave Square-where the frank, ready directed for his brother William, always awaited him-that Mr. Eastlake met distinguished members of both Honses and of the Government of the day. It was there that he attracted the notice of Sir Robert Peel, whose estimate of his character and attaimments brought him subsequently into pulblic employment. I find, in memoranda, signs of Sir Rober's's personal regird for him early in 1840. At this time the New Palace at Westuinster was so far in comse of erection (commenced in 1837) that the consideration of its internal decorations began to occupy a few minds. The first allusion to the subject is in a letter dated February, 1841: "Govermment, or rather Mr. Labouchere" (then President of the Board of Trade), "wishes to have a small grant " made for some experiments in fresco painting; and I "am told he wants to propose that some room or hall " in a public place should be decorated by way of trial. "I am also informed that he wishes me to have the direc" tion of it. I have said that, much as the plan interests 
"me, my engagements" (commissions for pictures) "are "such that I cannot soon take an active part in it."

The furst public step which eventually led to the appointment of a Commission for the Decoration of the Houses of Parliament-called the Fine Arts Commission-mas a motion brought before Parliament by Sir Benjamin (then Mr.) Hawes, "For enquiring into the means of promoting the Arts in this Country." A committee was immediately appointed to receive evidence, and Mr. Eastlake was among those examined before it. His evidence was felt (as expressed by the chairman, Mr. Hawes) to have been of peeuliar value-a private letter addressed by lim to $\mathrm{Mr}$. Hawes was also considered of importance, and appended to the Report of the Committee. There is no doubt that, while anxious not to be drawn into any position of labour or responsibility which should inter'upt the pursuit of his art, and the conscientious discharge of his commissions, he yet thus, and in other ways, had shown himself mmistakeably to be the right person to fill a part hitherto unrepresented-in which a practical and theoretical knowledge of the arts was equally required. In October, 1841, he was consulted whether he would consent to be upon the new Commission. This he declined, for the obvions reason that the Commissioners would have to select the artists fittest for employment.

In the autumn of $18+1$, Peter Colnelius, the well-known German historical painter, came to Loudon, and, whatever might be, as we have seen, Mr. Eastlake's opinion of his art, there was no doubt that he possessed experience in the practice of fresco. Mr. Eastlake's knowledge of German, and even of the technical terms of art in that language, enabled him to obtain from Cornelius mueh technical information, which he determined to publish, in case Govermment deciled to use this form of decoration. He had hardly arranged his notes when a letter from 
Sir Robert Peel, who was amare of Comelius's presence in London, suggested that which he had already donean example of the foresight and attention to details which distinguished that great Statesman. In answer to this suggestion, $\mathrm{Mr}$. Eastlake forwarded to Sir Robert a Report under eight heads, regarding the proposed decorations of the Houses of Parliament: namely, 1. Situation. 2. Strle of Architecture. 3. Fresco, as compared with oil painting. 4. Time necessary for the execution of works in fresco. 5. Practice of fresco painting. 6. Preparation of the walls. 7. Process of Painting. 8. Colours and implements. This Report, though founded on the statements of Cornelius, yet teemed with knowledge, ancient and modern, of a scope and variety of which the venerable German was guiltless. With Sir Rober't's miversally cultirated mind, and with his love for the arts, the thought may be permitted that this document opened to him a vista of interest in paths which, however full of charm, are but little trod by statesmen in general. To this Report Mr. Eastlake soon added a paper on the methods of fresco painting, as described by writers on art; in which every authority, furnished by his complete and constantly used library, from Vitruvins, Pliny and Palladio, to Sir Humphry Dary, Agricola, and Merrimée, and their bearings on the subject in question, were placed in the clearest order.* A few days after the reception of these paper's, Sir Robert Peel requested Mr. Eastlake to call on him, and after telling him that the Commission was now formally nommated, he handed him the official Instrument to read, which terminated with his own appointment as Secretary.

This interview is thus described to the erer srmpathising brother, 10th Norember, 1841. "Sir Robert watched me in " silence while I rearl it, and as soon as I had ended, said

* These two documents were printed in the Appendix of the First Report of the Fine Arts Commission. 
"he wished to conceal nothing from me connected with " my appointment, at the same time showing me his letter " (a copy, but in his own handwriting) to Prince Albert, " proposing my nomination. Sir Robert's recommendation " was expressed in the strongest terms-it would have "gratified you and George very much, as much as it dis" tressed me. I cannot remember it all, but the points " dwelt on were professional talent, knowledge of the sub" ject, and character". He then showed me H.R.H.'s "answer. It was by no means a letter of form, nor a "repetition of Sir Robert's expressions, but an acquiescence " apparently founded on his own observations and en"quiries. The Prince added that it would require the " utmost zeal and disinterestedness on my part. 'The hand" writing was large, plain, and careful. It was now time to "say yes or" no; but after the matter had gone thus far it " was evidently impossible to recede, and useless to consult " me. I did not forget to thank Sir Robert Peel, but I re" minded him that the prominent position I had taken in " this enquiry hitherto was quite accidental, that my letter " to Mr. Hawes was at first a private communication, and " that my happening to know Cornelius was also the sole " cause of my having been commissioned by himself to " consult him. He assured me that he had fixed on me to " fill this office (it being impossible under the circumstances " to place an artist on the Commission) before Cornelius " came to this country ; that he had consulted the Duke of "Sutherland and others, who had all agreed with him. "Lastly, he said that he had consulted Chantrey, and that "Chantrey had said he could not have fixed on a better "person." 


\section{CHAPTER VII.}

First Meeting of Commission, March, 1842,-The I'rince Consort. - Exhibitions in Westminster Hall.-Arduons labours.-Division of time. Sources of happiness.-Fête at Campden Hill.-The Summer House. - Her Majesty.-Visit to Drayton.-Characteristics of Sir Robert Peel. -Death of brother William.-"Materials."-Letter from Mr. Leslie, R.A.-Elected President of Royal Academy.-Commission of 1851.Prince Comsort at Academy Dinner.-Director of National Gallery.Illness.-Death.

IT is beyond the scope of this memoir to attempt to follow the workings of The Fine Arts Commission, or its results as respects its influence on the public taste. It is unnecessary also to dwell further on Mr. Eastlake's fitness for the appointment he had just received, or on the labours which it entailed during above twenty years of his life. Abstractedly, it was the last position desired by one of whom I have said little to purpose, unless to show that his painting room and his library bounded his desires and ambition. But there is a Destiny that shapes our ends, and in the stimulus thus applied to his sensitive but powerful nature, in this responsible and honourable office, energies and capacities latent in him were developed, of which he had himself been unconscions. The Commission found, that in addition to a Secretary furnished with unusual stores of learning, they had obtained the services of one endowed with a singular aptitude and patience for that accurate and multifarious rork called "business." A resum" of his labours will be found in the appendices to the various Reports he drew up for the Commission; selections from which have been published in the Volume of "Contributions."

At the first meeting of the Commission, when all present 
were more or less untried in the discussion of the class of subjects before them, Sir Robert Peel observed the new Secretary, somewhat, perhaps, with the anxious feelings of a reteran watching a novice, as he gare the Chairman and members what he called "a lecture;" illustrating it with specimens, drawings by fresco painters, \&c., including the fragment of a real fresco by Paul Teronese; and showing the self-possession, in the presence of auditors of no common class, of one who felt secure of his subject. But more interesting than subject or Secretary was the youthful and royal Chairman, then, I believe I may add, brought for the first time into the transaction of public business in the country of his adoption-whose untiring and intelligent zeal in the service of this Commission, at once gave a measure of those indefatigable labours for loftier objects to which his short and glorious life was devoted. No artist employed in the works of the Commission, ever approached the Prince withont recognising a clearness of perception, regarding the purposes and principles of art, which contrasted curiously and refreshingly with the rague, and often false conventionalties to which the rotary of art is generally doomed to be a listener. This first meeting laid the foundation of that which redounded to the credit of all-namely, of the deference which throughout was shown to the Secretary, when, as he modestly expresses himself, "on my "own groumd.",

Previous to this first meeting, the Prince had desired Mr. Eastlake to wait on him at Buckingham Palace. It was the first time Mr. Eastlake had seen H.R.H., and as a painter, he may be excused for a painter's remark-namely, that "the Prince stood in a strong light, which showed his "beantiful face to great arlvantage." On this occasion the Prince discussed the objects and plan of the Commission; Mr. Eastlake umeserredly making objections where he thought them necessary. "'Two or three times I quite for- 
" got whohe was-he talked so naturally and argued so fairly." This conversation couvinced Mr. Eastlake that certain rumours which had prevailed regarding the Prince's intention to employ German artists, were wholly unfounded. The Prince did not sanction the employment of German workmen even for subordinate labours, and expressed his conviction that in all that belonged to practical dexterity, the Englishman took the lead of the foreigner.

One of the first measures determined on by the Commissioners (mentioned here, because leading to an important exhibition), was to invite a competition of Cartoons, of designs calculated for fresco; the subjects to be selected from British History, or from the works of Spenser, Shakspeare, or Milton. This competition was opened to all artists, and a trelvemonth was allowed for preparation. The result brought to light an unexpectedly large number of fine works, which were exhibited in Westminster Hall. So auspicious a beginning especially delighted the Prince. On the 1st July, 1843, Her Majesty visited this interesting and novel display, accompanied by the King and Queen of the Belgians. The Prince immediately presented Mr. Eastlake to the Queen, but acted himself as cicerone, taking Her Majesty from one side to the other with eager interest. As the first occasion, followed by others more memorable, on which the Queen inaugurated an Exhibition presided over by her lamented husband,-and one on which the youthful pair gave public evidence of that mion of taste and interest which resulted from a higher bond-this Exhibition of the Cartoons, now well-nigh forgotten, has a mounful significance. The Cartoons were 141 in number. Three premitms of 300l. each, three of 200l., and five of 100l., had been offered, but were not found equal to the number of the approved specimens, and ten more at 100l. each were added.

The eclat giren to the occasion by Her Majesty's risit, by 
the Prince's participation, and by its intrinsically novel and interesting character, rendered this exhibition, opened at first for a shilling, a very fashionable resort. At the expiration of a fortnight, the public were admitted gratis, except on Saturdays, when the attendance exceeded all expectations both in number's and intelligence. "July 22nd, " 1843. The daily throng is immense; the public takes great " interest, and the strongest proof is thus given of the love of " the lower orders for pictures, when they represent an event. "I abridged the catalogne to a penny size for the million, " but many of the most wretchedly dressed people prefer" " the sixpenny one with the quotations, and it is a very "gratifying sight to witness the attention and earnest" ness with which they follow the subjects with the "books in their hands. Ten thousand of the sixpenny " catalogues have been sold." (It had then been open to the public for a week.) "The higher classes com"plained that the Exhibition was not open longer for a " shilling, but the Commissioners have wisely determined " to let it remain for the public as at present, and for" " several weeks to come. Clerks of counting-houses have "petitioned to be let in on Sundays, but this cannot be " granted. The gates are closed from time to time when " the Hall is full, and the people are let out through the "Law Courts. Meanwhile the new comers collect in "crowds, waiting for admission, and carriages draw up, " subject to the same necessary delay. No possible arrange" ment, and no number of hands, conld regulate the deliver'y " of umbrellas and sticks, and the unclained ones have " accumulated in consequence. I have therefore directed " the doorkeepers to use their discretion, and let in many " with their umbrellas. The question of clress I lave " settled, of course, without any line of demarcation; only " cliildren are not let in under a certain apparent age. "They are nevertheless carried in with the throng, and as 
" the policemen collect them they are walked out again in " droves, and packed up for a time in the vestibule till "there is room to get out. All the workmen from the "Houses of Parliament go in, but chiefly in the evening; " because, being as white as millers (the masons), they have " the discretion to time their visits.

"You will see by the Catalogue that the references and "quotations are good of their lind, being indeed from the " highest sources. I stated to the Commissioners yesterday, " in reporting about the Exhibition, that the Catalogues in " the hands of so many thousands, would be the first intro"duction of many to an acquaintance with our best poets " and writers."

Between twenty and thirty thousand a day visited this Exhibition, which was kept open for two months. It was succeeded in April, 1814, by an Exhibition of Specimens of Decorative Works of Art, in Crockford's Bazaar, St. James'; in July, 1844, by one of Specimens of Fresco and Sculpture, accompanied by more Cartoons, in Westminster Hall; in June, 1845, by a mixed Exhibition of Cartoons, Frescoes, Coloured Sketches, and Sculpture; and finally in June, 1847, by one of Paintings in oil; both these last being in Westminster Hall. In all these instances premiums were awarded to the most successful works.

The amount of labour attending these occasions, and the fact that every subordinate department of art connected with the internal decorations and completion of the Palacethe carved work, parquête work, metal work, stained glass, arabesque decorations, encaustic tiles, \&c.--came also under the inspection and decision of the Commissioners, shows how conscientiously they addressed themselves to the task they had undertaken; also how multifarious and unceasing were the labours of the Secretary. Into all this he entered with the feeling of a painter, and also with the patient inrestigation of a man of science, asking for no help, and 
leaving nothing to others to do. And he knew that his brother William's kindred spirit would sympathize fully with him when he said, "We are too conscientious and anxious " to do anything by deputy." He might well add when engaged on a picture of deep feeling, with all this sea of interruption breaking in upon him, "if ever I drew the arrow to "the head it must be now." This was doubtless the busiest period of his life, though, from the more active and social nature of his official occupation, it was not so trying to his health as his later Roman residence had been. He suffered, however, every winter from delicacy of chest and lungs, so as to be often disabled.

It is no wonder that Mr. Eastlake's note-book shows fewer entries of pictures from 1840 to 1850 , yet his Hagar and Ishmael, Heloise, Visit to the Nun, Helena, dre, bear evidence that the inspirations of beauty were not fading from his mental sight. His kind brothers remonstrated gently on this undue devotion of the years of his prime for what they conceived was inadequate compensation-his salary was 700 l. a year-and suggested the possibility of a position in which the duties would be lighter. He replied to them, December, 1844: "I prefer a situation in which I can influence the " arts of the country to a private sinecure." These words are a clue to further duties which he undertook. There is no doubt, also, that the exercise of those faculties for business and organisation which had hitherto been undereloped was pleasing to him as the sense of a new power.

In April, 1842, Mr. Eastlake accepted the office of Librarian to the Royal Academy, which he held for two years, and I believe I am justified in saying that he left the mark of his supervision upon the Catalogue of that Library. In November, 1813, he undertook the office of Secretary to the National Gallery, vacant by the death of Mr. Seguier, and flatteringly pressed upon him by Sir Robert Peel. This he held till 1847. About this time he laughingly 
complains that people seemed to consider him the only person qualified to give help and advice in matter's of art:he was requested to accept the Curatorship of the pictures belonging to Greenwich Hospital; he was proposed to be sent out as Director of a contemplated English Academy at Rome; he was again requested to mulertake the superintendence of the Schools of Design; and he was consulted equally whether a picture was for purchase or for sale, by many who had not the slightest claim upon his time.

Order and pumctuality were, it is needless to say, the secrets of his successful industry, aided by a memory which embraced the smallest as well as the most important, the driest as well as the most interesting matter's. 'The painting time was usually restricted to the season least fitted for it; namely, to the winter, when Exhibitions and Fine Arts Meetings were suspended. Thongh his eyelids had suffered in Italy, yet his sight continued good. At all events, he did not spare it. In Jannary, 1844, he mentions working five and six hours by lamplight. "I dine at 6 , and from 7 o' clock " till 12 or 1, or even later, my lamp is buming. I break"fast at half-past 8 notwithstanding my late hours. Every" "position has its advantages, the difficulty is to tur'n them "to account. Iytton Bulwer has a pithy German motto to " one of his novels. The burthen of it is that "Here in " this hampered, despised actual, here or nowhere is your" " Ideal-work it out therefrom.' When a painter has a " crabbed subject to deal with, as I have now (from Comus), " he should try to make it interesting. Wilkie once, walking " round the Exhibition with me, compared the pictures of "two artists, and said that of all the definitions of Genins "the most intelligible and attainable was 'the power of “ ' making use of your materials.' As George heard Mrs. "Jordan say, "Many a character one has to perform is in " "itself insipid, it all depends on what you can put into it." 
"Every profession, every place, and every occasion has " its Ideal, and if the word is not quite the right one it is " because the judgment has more to do with the use of cir" cumstances than the imagination... Perliaps in all " cases the surest road to happiness is labour. A fuller " definition would be "intensity of will in anything that the " 'conscience approves.' The degree of happiness would " then be according to the thing laboured for. The most " exalted motives are rare, and fortmnately mnecessary for " tolerable peace of mind; but an instance of intensity of " will in what the conscience highly approres might be found " in Howard visiting prisons. Intensity of will, even in " things indifferent, is a source of happiness. Some finely " constituted natures cammot do or say anything without " putting their soul into it; their faculties are always active " and earnest; they live thrice the life of ordinary vegetating " people, and communicate their energy more or less to " those about them. But this, an habitual virtne (at least " in society), is not to be confounded with intensity of will " in the performance of real duties. That I believe is the " secret of happiness of the best kind. Lastly, intensity of "will in anything bad, and which the conscience disap"proves, so as to produce mental satisfaction, would be "Satanic, and is the key to Milton's character of Satan." Again, on the same subject. "In my last letter I was "led to make some observations the train of which was, I " believe, suggested by some remarks of yours" (his brother William's). "I observed that intensity of will in the pro"secution of a good object is a tolerably good definition of " happiness. Volition lears to action, but where action is " in a great measure denied, as in your case, the activity of " thought may be a source of happiness. (Aristotle says it " is the only happiness of the gods.) The perfection of " the moral being, a perfection unattainable in this world, " must consist in the identity of the human will with the 
“ Divine Will, 'as it is in hearen.' The study of the "Divine Will is what the Apostles never cease to recom" mend."

With all the business that occupied him, pleasure (or relaxation) was happily not quite given up. A déjêner at the Duchess of Bedford's at Campden Hill, gires a pleasing glimpse of some he knew, and whom many have known. "I met at the same moment Col. Gascorme and Lord " Leven, with both of whom I travelled in Sicily. Lord " Leven presented his daughter to me, now grown up. . . . "The children of all the visitors who had any were there, "and Punch (the puppet-show) was in a corner of the " beantiful lawn to amuse them. It was pleasant to see "them in front with their attentive faces, while the grown"up idlers sanntered about. There were plenty of straw"berries and cream for all ages, and a cow was tied to a "tree to be milked when required. Lady MLodey re" marked that the lowings were periodical, and main" tained that they pinched its tail to make it all rural. It " was observed that two grown-up visitors were as intent on "Punch as the children, viz., Lord Glenelg and Miss Fox. "Lord Holland, her late brotiner, might have been as much " amused, and would have owned it as readily. I walked " away, intending to get into an omnibus at Kensington, " but had not gone far before I heard my name called from " a carriage that drove by me and stopped. It was Lord "Leven and his danghter. They made me get in, and I "left them in Arlington Street. A boy came out of the " house as we were standing talking together. Lord L. " said, 'Here's Balgonie, bearing the same name I bore “ ' when I first knew you.' Pleasant encounters! but all cal" culated to make one feel somewhat old."

Meanwhile the position he occupied, though it diverted the course of the true painter, had great compensating privileges; foremost among which were the occasions of 
easy communication with one who stood equally pre-eminent as a Prince and as a man. The Prince Consort was then in all the first ardour of youth-as yet comparatively unfettered in leisure, and unworn by work. He may be said to have first won his spurs, as regarded public business, in the condnct of the Fine Arts Commission, for, after the Secretary, none thought so much or toiled so umemittingly on its behalf. The Prince took particular interest in the art of fresco, hoping that the impulse given to its development by the Fine Arts Commission wonld elevate the English school and the public taste, and lead to decorations of a monumental character within the comntry houses of the English nobility. While competitions were invited, as related, of specimens of fiesco, he formed a plan by which the chief painters of the English school could make private essay of the art within the precincts of Buckingham Palace. A Summerhouse, or Pavilion, had been recently erected on an elevated portion of the grounds originally formed during the excavation of the lake. It was of an octagonal form, tastefully painted within with arabesque decorations; and eight lunetteshaped compartments remained, fitted to receive designs in flesco. The subject of Comus was chosen, and eight of the principal painters agreed each to undertake a compartment.* Mr. Eastlake was among the number, selecting for himself the least farourable compartment-that over the fireplacewhere he stood to paint in his own light. His period of leisure only allowed him to undertake this commission during the winter-January and February of 1844-when he was constantly a witness of the great interest Her Majesty as well as the Prince took in the progress of the work-being hindered by no weather, even with snow on the ground, from their early visits to the Summer House. It would be

* The order in which the painters follow each other in the small space is as follows: Stanfield, Uwins, Leslie, Sir William Ross, Eastlake, Maclise, Landseer, Etty. 
unbecoming to give anecdotes, however respectful, of these exalted personages thus seen in their private life, and on occasions of gracious condescension towards the object of this memoir; but a few lines may be quoted embodying Mr. Eastlake's first impressions of Her Majesty; impressions which his own refined taste as well as the undesigned nature of the admiration render the more interesting. "The perfection with which my imagination soon “ endowed Her Majesty was a most agreeable voice, and " a pronunciation of English fit to be an example for" " all her subjects. If you were to hear it without seeing " the speaker, you would associate with it a musical ear "and a consummate education, but combining with the " impression of fominine taste that of the conscionsness " of power."

Another very highly valued result of the position now occupied by Mr. Eastlake was the friendship entertained for him by Sir Robert Peel. His visits to Drayton-and on one occasion he was the only guest-opened scenes of domestic English life of peculiar attraction to him. He here saw the great statesman in all the variety of character that belonged to him;-the country gentleman-the ardent farmer-the kind neighbour-the philanthropist-the man of lettersthe patron of art-and the centre of happiness in his ow family; while occasionally he touched on those larger and profounder topics to which his life was mainly devoted. The subjects of art and artists and the best mode of promoting and benefitting each took of comse the lead in the tête-à-tête walks on the noble terrace, interspersed with plans for obtaining more space for the National Gallery, and for enlarging the sculpture-room at the Royal Academy. And while Mr. Eastlake wondered how his distinguished host could give his mind to so many topies-and to all with thoroughness - it was with no little surprise that he disovered that Sir Robert had read and mastered the Handbook 
of Italian Painting, by Krugler, lately edited by himself. At Drayton, too, he met the leading men of every class and country, who offered points of contact with Sir Robert Peel's extended interests and duties. Dignitaries of the church, men of science, authors, members of the Gorernment, foreign ministers-including his old acquaintance, Chevalier Bunsen, \&c.-while he quietly records a feat of no small import to those who know his adversary, namely, that he beat Baron Brunow in a game of billiards.

A tribute to Sir Robert Peel's character and habits, howerer superfluons, can never be out of place from the pen of one deeply indebted to him. "The excellence of Sir " Robert Peel's administration, in which he is imitated by " his subalterns is, that while able and ready to grapple " with the largest and most difficult questions, he thinks " nothing really connected with business too insignificant " for his attention. He probably, in early life, began with " accurate habits, which make such an attention to details "always easy, and which are the best foundation for " enlarged experience. A slip-slop workman is good for " neither; le can neither be a plodder nor a plilosopher. "Withont attention to the business of the moment there " can be no accuracy, withont accuracy and indnstry (the " evidence of zeal) there can be no extensive lnowledge of "facts and details, which are the pabulum of judgment, and " the only true groundwork of theory."

In $1845 \mathrm{Mr}$. Eastlake experienced the great loss of the brother William so often mentioned in these pages. There are frequent records, in his letters to his only remaining and also highly valued brother George, of the gap thus left in his life. By this death he became the possessor of the small country seat at Plympton, called St. Mary's Hill, which had belonged to his father. In the midst of all his official labours he found time to pay minute attention to alterations and additions tending to improve 
and ormament the place; and some Italian features remain which bear witness to the hand that designed them. Eren the garden engaged him deeply ; one of his standing orders was "plant more holyhocks." But chiefly he found fresh sources of interest in some of the younger members of his brother's family; all his nephews and nieces in turn being the objects of his constant attention and advice in his letters to their father. By his urgent recommendation and assistance one of his nephews, - his namesake,-whose memory gratefully endorses these slight allusions, * was placed at Westminster College School. Every Saturday till Monday the little fellow was welcomed by the kind uncle, who laid aside his cares and rork, and deroted himself to be his "help,"-a term used in that school,-reporting to his brother the pleasure he took in the jurenile student. "As to " his progress, nothing can be more satisfactory. We work " hard together' when he comes to me, and we shall continue " to do so till we have gone as far" as his Fitzroy Square + " master can teach him. . . . It is of great importance "that he should come to me on Saturdays as often as " he can, as I can always solve some of his difficulties. "Whether it is that I am unaccustomed to the society of " children, or, which I rather believe, that there is some" thing peculiarly pleasing about this unsophisticated little "fellow, as he now is, I know not, but his presence is " as a beam of sunshine, infusing feelings that make me " acknowledge the force of that injunction that we should " in singleness and purity of mind become as children. " Last Monday evening, to please Charlie, who wishes to " be thought able, and is able, to take care of himself, I "walked with him to an omnibus which was going as far

* Mr. Charles Lock Eastlake, the architect; Secretary of the Institute of British Architects.

$\dagger$ Sir Charles purchased the house, No. 7 , Fitzroy Square, which he subsequently occupied, in 1842 . 
"as Charing Cross, and left him to his fate. But the " next morning I was not easy till I had sent down to "Westminster to know if he was safe. Tucker* saw him "playing on the Green."

'These trivial facts are only given as helping to show the fullness of a character on which I dwell with sad delight. One more aspect of it yet remained to be developed; this was called into life by om marriage in 1849 . On the happiness of that tie, and on the poignancy of its earthly severance, I must forbear to dilate.

It was in 1847 that the first volume of his work, entitled "Materials for a History of Oil Painting," was given to the public. This was originally commenced in the form of a treatise intended for insertion in the appendices to Reports of the Fine Arts Commission. 'The subject enlarged so much, however, under the thoroughness of his research, as to be too bulky for its destination; also, it may be added, too valuable to be comparatively buried in a Government Report. The Prince, to whom he submitted the question, entirely approved of the separate publication of this work. The volume, though appealing to a very limited public, was received by the periodical press with great respect. It has been translated into Italian, and is now in process of translation into German.

But though, in this instance, his labours became more generally known, yet he continued, on other subjects, to fill the Fine Arts Commission Reports unstintingly with the fiuits of a life of study. Not that these were wholly lost to the public even in this shape, for the attention drawn to them by the profession raised a partial demand for these documents. $\dagger$ A letter from his friend, the late Mr. Uwins, R.A.,

* Sir Charles' faithful man servant.

$\dagger$ A selection of these essays, with other writings by his pen, were incorporated in the volume entitled "Contributions to the Literature of the Fine Arts," edited by Mr. Bellenden Ker, in 1848. 
gives a grateful tribute to the indefatigable labourer in the cause of Art. "February 26, 1846.-I lave read "your 5th Report, and read it with no small attention " and interest. You are certainly an extraordinary person. " While others are making a parade of books and lectures, " merely to announce a few uncomnected truisms and " commonplaces of very ordinary practice, you are opening " up the whole philosophy of the Art to all who have heads " to understand;-all, forsooth, under the humble title of "Reports of the Fine Arts Commission. Time will come "when these modestly put forth papers will be quoted as " the highest authority on the several subjects on which " they treat."

The time was now approaching when the office which invested him with most honour, and by which he is best known to the world, was about to be conferred. During the latter years of Sir Martin A. Shee's life, when failing health entirely witharew him from the duties of his officeconscientiously performed in the interim by the Keeper of the Royal Academy, the late Mr. George Jones-the idea gradually obtained in the artist world that Mr. Eastlake was destined to succeed to the Presidentship. 'This surmise fiequently reached him, and from quarters best justified in bringing it before him. His reserved habits, modest self estimate, love of his art, and interest in the duties of the Fine Arts Commission, led him to shrink unequirocally from such a prospect. Nevertheless, there could be no donbt in the minds of some who looked on, that his scruples would ultimately be overborne. The subject had been introduced to him by Her Majesty with gracious condescension, and by Sir Robert Peel with cordial friendship. On both these occasions the desire had been expressed that, in case of the honour being offered, he should accept it; and also the conviction that its acceptance would be compatible with the continued exercise of his duties as Secretary to 
the Fine Arts Commission.* On the other hand, on the part of some of the members of the Royal Academy, the desire that he rould erentually occupy the chair was conreyed to him in terms at once generous and complimentary. As early even as the period of Howard's resignation of the Secretaryship of the Royal Academy-in 1846-a letter reached him from his friend $\mathrm{Mr}$. Leslie, the painter,man as much esteemed by his fellow artists as distinguished in his profession,--which I need not apologise for inserting here.

" Tovember 18, 1846.

\section{"Mr dear Eastlane:}

"There is, of course, as you know, a stir in " the Academy in consequence of the probability of " Howard's resignation. Several of my friends have asked " me to offer myself as a candidate, which, for several " reasons, with which I will not waste your time, I shall " certainly not do. My object in writing to you is to " entreat you to offer yourself the moment the vacancy " occurs. I do hope, for the sake of the Academy, you " will. I suggested this last night to Uwins, who said " what I believe most of us know, that you are looked to " as our future President. Very possibly you yourself are "the only person in the Academy not looking forward to "such an erent. Be that as it may, I stated to Uwins " that your acceptance of the Secretaryship could not

* Of interest in ancther sense of the word there was little at that time to attach him to this office. Desirous of securing more leisure for the practice of his art, he asked permission to depute some of the less responsible labour of the Sccretaryship to his friend Mr. Aubrey Bezzi : and in order to induce the members of the Commission the more readily to accede to this proposal, he surprised them by the unusual and over honourable request that his salary might be reduced from 7007 . to 5007. a year. Out of this $500 l$. he paid Mr. Bezzi 200l. a year. He tlus gare his own services, in which I need not say he never relaxed, for very small compensation. Subsequently, the salary was restored. 
" possibly interfere with your being chosen President, as "I have no doubt you will be whenever the time for such " choice arrives. I know you better than to suppose this " explanation can have any weight with yon one way or " other. I merely state it as my own view of the case; " and you must allow me to repeat my eamest wish that "you will become a candidate for the Secretaryship. I " wish (as the Irishman said) you could be 'two gentlemen " ' at once,' for the very character' of the Academy may be "said to be in the hands of the President and Secretary. " Excuse all this, from yours very truly,

$$
\text { " C. R. Leslie." }
$$

In August, 1850, the death of Sir M. A. Shee took place, and in the following November Mr. Eastlake was elected by the members of the Royal Academy to the office of President. Their choice was confirmed, and the usual honour of Knighthood conferred, shortly after by the Queen. However unwilling in anticipation to accept a position involving responsibility of so prominent a character, I shall be believed when I say, that none of his predecessor's undertook this oflice with a higher conception of its duties - a more just estimate of its distinctionor a more grateful feeling personally, towards all his brethren of the Royal Academy. With a desire, hardly acknowledged to himself, to avoid rather than attract the suffrages of the members, he had of late years withdrawn from all but absolutely necessary participation in the business of the Academy. He now threw himself into it with ardour-with all his equity of feeling and amenity of manner-exciting in many, to whom he had been scarcely known, a pleasing self-gratulation in finding their expectations surpassed in the object of their choice, while his friends rejoiced in the fulfilment of their generous confidence. It was thus that Mr. Cockerell, the valued friend 
of his youth, and of our maturer time, expressed himself in a letter not written to meet our eyes, from which I may be permitted to give an extract: "Eastlake is always ad" mirable, through good and evil report. His Presidency is " invaluable-earnest, steady, most judicious, business-like, " kind, full of tact, consideration, and even policy-but of " an honest and wholly unselfish policy, and, when need be, " bold, as backed by honesty."

The first year of his Presidentship was that of the Great Exhibition of 1851. As early as 1849 Sir Charles Eastlake had been appointed one of the twenty-six Commissioners; and his subsequent elevation to the chair of Reymolds lent a further propriety to the part he filled in the great undertaking. The presence of the Prince Consort at the Royal Academy dinner of 1851-the first amnirersary on which Sir Charles presider-was the occasion of a speech which by its admirable sense and perfect sympathy excited the enthusiasm of all present, and added another to that series of admirable addresses on widely differing topics which the lamented Prince has bequeathed to the country. The presence of His Royal Highness was the more flattering to the Royal Academy from the cireumstances which at that time drew upon him the attention of the civilised worldfor the Great Exhibition had just been opened-and this presence, as the Prince amiably stated, was due to his personal regard for the new President. Although these addresses have been rendered accessible to all, I venture to transcribe the words in which the Prince expressed himself on this day: "I have on this occasion made it a " point to attend the dinner in order to assist at what may " be considered the inauguration festival of you" newly " elected President - at whose election I have heartily " rejoiced, not only on account of my high estimate of " his qualities, but also on account of my feelings of " regard for him personally. It would be presumptuous 
" of me to speak to you of his talent as an artist, for " that is well known to you, and of it you are the " best judges - or of his merits as an author", for you "are all familiar with his books, or, at least, ought to "be so-or" of his amiable character as a man, for that "also you must have had opportunities to estimate-but " my connection with him for more than nine years on "Her Majesty's Commission for the Promotion of the "Fine Arts, has enabled me to know what you can know "less, and what is of the greatest value in a Presirlent " of the Royal Academy;- I mean that kindness of heart " and refinement of feeling which have guided him in all " his communications, often most difficult and delicate, " with the different artists whom he had to invite to com"petition; whose works we had to criticize, whom we "had to employ or reject." As he thus spoke the Prince laid his hand kindly on Sir Charles' shoulder.

It is not irrelevant here to remark, on looking back on the biography we have been tracing, that this appointment seemed to grow naturally out of the previous conditions of his life. He had, it may be said, been throughout his course in training for the position which he had attained - a training matured equally as regarded the practice, the means, the aims, and the listory of art; and of late years completed by those dealings with his fellow artists to which the Prince referred. The period at which the Royal Academy had now arrived was a crisis both in art and its affairs. Old styles of art were disappearing, and new styles starting up ; and there was scarcely a period when the vigilant inculcation of sound practice and doctrine was more urgently required. How far the stimulus and employment given to artists of all classes by the labours of the Commission had borne beneficial fruits to art itself, it would be difficult to trace. In Sir Charles' own words in a speech at an Academy dinner, on referring to these labours-to 
the increased interest in art evinced by the public-to the farour of Her Majesty, and to the energy of the Prince" such results are not always traced to their most important " causes-indeed an example is the more successful in pro" portion as it is followed unconscionsly."

At this time the idea of dignified ease usually attached to the position of President of the Royal Academy, was temporarily, if not finally dispelled. The Institution was exposed to a storm of criticism and enquiry; and the highest personal qualities in its presiding head, for the maintenance of confidence from within and withont, were never more indispensable in the interests of the Academy. However favourable therefore the circumstances under which he commenced office, however respectful, faithful, and helpful the support of the leading members, I am quite sure that none still surviving, who sate under him, will gainsay the assertion, that the course of the Academy, during the fifteen years of his Presidency, entailed no common amount of labour and anxiety on the conscientions Steersman.

It is not for me to attempt to catalogue the measures which he supported or brought forward. They may be summed up in general as abrogations of privileges to the Body, and as additional advantages to the schools, or, in other words, to the arts generally; his master principle being ever kept in view, that the true object of the Royal Academy, its only source of invulnerability, was to promote the good of the Public, before that of its individual members.

Subordinate in importance to internal reforms and improvements, and yet temporarily more instrumental in gaining popularity, both to the Institution and the President, may be mentioned the greater publicity, as well as higher character given to that yearly dimer by which the Royal Acarlemy inangurates each successive Exhibition. The presence of the Prince, and his remarkable speech, led, 
for the first time, to the introduction of reporters, and the public journals have since made known to the world those annual speeches, in which, while Statesmen have relaxed in playful encounter, Sir Charles never failed to enunciate - incidentally or directly - some principle of art, some testimony to enlightened taste, or some tribute to the departed artist.*

According to established custom, he delivered a lecture biennially to the students of the Academy. These, while directed to subjects of techinical practice and philosophy, yet appeal to general principles in which most cultivated minds would find interest.

My task now draws to a conclusion. The aspirations of his youth,-the training of his mind--the development of his character, I have endeavoured, and chiefly in his own words, to lay before the reader; the more public part of the career, as I before observed, has needed briefer notice. In 1855, in addition to his other occupations, Sir Charles accepted the office of Director to the National Gallery. In this position, the most interesting and delightful at that time which the painter, the comnoisseur, and the man of taste could hold, though one of no exemption from toil, he found employment of a peculiarly congenial nature, and reaped the choicer fruits of his life of labour. While finally banishing him from his painting-room, the confinement, and-with lis erer increasing fastidiousness

* Much more might be said-perhaps ought to be said-on the character of Sir Charles' speeches on these oecasions. They are vividly remembered as unique of their kind by many whose admiration is a high tribute. Year after year their grace, propriety, and perfect adaptation to the special purpose were welcomed with keener attention and renewed interest; while not a few of the distinguished guests listened with mingled pleasure and surprise, who were familiar with the difficulty of infusing variety into ever recurring topics. The excellence of these addresses may in some measure be defined as the result of a cultivation of mind and purity of taste which equally interdicted redundancy or display. 
- the anxiety of which were rery trying to his health, this office gave him back that which holds at all events the second best place in a painter's heart, - the constant society of fine works of art. Abstaining therefore from further creations of his own hand, he found a painter's interests and delights - if also something of his labours - in the closest study of those old masters to whom he had ever given reverential allegiance. The fortunate necessity of travelling in quest of pictures was the best restoratire for mind and bodr, after the fatigues of a London official life. Year after year the happy tour was made, always to Italy, once to Spain, and frequently on fruitful errands besides to France, Belgimm, Holland, and Germany. And all the charms of travel were enhanced by a purpose, honourable and responsible, which kept up those habits of thought and industry, without which pleasure would have been none to him. No fatigues or discomforts deterred him from visiting the remotest parts of Italy : wherever the prospect was held ont of securing (and in most cases it was rescuing) a work of interest, he patiently made his way; and before every picture, whether in church, convent, or private house, worthy of his investigation, accurate notes were taken, and every evening carefully transcribed.* Wherever he became known, respect and confidence followed him, and, if in a few instances his thorough experience and judgment frustrated attempts at imposition, they far oftener dereloped a generous and honourable recognition from the nobler side of the Italian character. While conscious that these foreign duties eventually entailed circumstances, which, humanly speaking, are believed to have shortened his precious life, it is a consolation to me to remember how often he returned from these jomrneys reinvigorated in spirits and

* A large collection of notes remains in my possession, which have been copied and catalogued alphabetically, and put at the service of the present Director of the National Gallery. 
health, and how greatly they contributed to enrich the National Gallery.*

He left England on the 3rd Angust, 1865, exceedingly unwell. This condition had too often occurred for us not to press forward to that desired land, the soft air of which had so often restored him. On my part, however, there were, on this last occasion, more than usual misgivings. On crossing the Simplon, and reaching Domo d'Ossola, he immediately felt relieved, but the next day, which took us through the beantiful scenery which leads to Baveno on the Lago Maggiore, was the last day of health to him. At Milan, which was soon reached, twelve sad weeksthough broken by interrals of partially retmining strength and hope-were passed. They were sncceeded by five weeks, sadder still, at Pisa. He died there on the 24th of December. ${ }^{+}$

* 139 pictures were purchased for the Xational Gallery by Sir Charles Eastlake; 29 pictures were presented and bequenthed in his time.

+ Sir Charles Eastlake was buried first in the English cemetery at Florence, on the 27th December. The wishes of the Royal Academy which reached me later, and certain doubts entertained of the permanent inviolability of the cemetcry at Florence, led me to permit his remoral to this country. He received a public funeral from the Academy, and was buried in Kensal Green on January 18th, 1866. I declined a public funeral in st. Paul's Cathedral, as not consonant with his wishes. 


\section{WORKS EXECUTED BY SIR C. I. EASTLAKE.}

SUBdECT.

Raising of Jairus' Danghter .

Brutus haranguing the Romans on the death of Incretia

Buonaparte on board the Bellerophon

Cicero in his Villa at Pozzuoli .

Marius in Carthage. . . . .

Two drawings to illustrate Horace .

Forum of Nerva (water-colour drawing)

View of Arco de' Pantani . . .

Paris and Mercury (figures life size) .

View of Coliseum from English College

Garden

View of St. Peter's from Pamfili Gardens

View of Temple of Antoninns and

Faustina

Scene in Mæcenas's Villa, Tivoli

Scene in Convent near Coliseum . .

Scene in Colonnade of St. Peter's . .

Scene on Palatine Hill . . .

Scene in Villa Albani . . . . .

View of Temple of Erecthens, Athens .

Temple of Vesta at Tivoli . . . .

Scene in Colonnade of St. Peter's . .

Scene in Villa Albani . . . . .

Scene on Palatine Hill . . . .

Portrait of Mr. Abercrombie . .

Popy of portrait of Torl Jorley

A Brigand . . . . . . Mr. Cholmondeley . . . 1820

A Contadina. . . . . . The same . . . . . 1820

A Contadina . . . . . . Mr. Dyson . . . 1820

View of Temple of Thesens, Athens : Eurl of Guildford . . . 1821

View of Bridge and Castle of St. Angelo Lord George Quin . . . 1821

View of Coliseum from Temple of Peace The same . . . . . 1821

View of St. Peter's from Monte Mario . The same . . . . 1821

Temple of Erecthens at Athens . . Mr. Devon . . . . . 1821

Temple of Theseus with Battle . . The same . . . . . 1821

View of Coliseum from Temple of

Peace

Garden . . . . .
The same . . . . 1821

Ifr. Serope . . . . 1821 
SUBJECT.

FOR WHOM PAINTED.

WHEF

FTNISHED

A Sonnino Woman

H. Serope . . . . . 1S21

View of the Trajan Formu

Wiss Catherine Fonshare. . 1821

The same, smaller

Scene at Arsoli .

Ir. Boileau . . . . 1821

Sonnino Woman and Wounded Brigand

A Sonnino Woman and Brigand

Countess of Whestmorlamet

1821

Sir George Beaumont . . 182i

A Sonnino Woman and Brigand .

Nir. Mill

Sir Moore Disney . . . 1822

A Beggar and Contadina.

Lord George Quin . . . 1820

A Beggar and Contadina

Mrs. Harman

A Sonnino Woman, and Brigand aslcep

Wr. Intchinsm

1829

View of Colisenm from English College Garden

Mr. Greville Howard

1822

View of Coliseum from Maronite Convent

A Brigand Wounded, and other figures Goatherds in the Campagna of Rome . Scene on Palatine Hill

Another Scene on Palatine Hill

Another Scene on ditto

The same , , . . 1892

Mr. Hutchinson . . . 182?

Sir Moore Disney. . . . 1823

1H. Greville Howard . . 1823

The same . . . . 1823

The same . . . . . 1823

Another Scene on ditto . . . . The same . . . . . 182:?

A Contadina and Children . . . Wr. Sherpshanks . . . 1823

A Brigand

A Brigand's Wife .

A Classical Landscape

It: Earle . . . . . 1823

The same . . . . . 182?

Earl of Orforel . . . . . 1829

Mr. Hutchinson . . . 1824

Mr. Dueane . . . . . 1824

A Brigand in Concealment . . . Sir H. Hyre . . . 1824

A Girl of Albano and Blind Woman, (half figures).

A Contadina and Children

Mr. D. Baillie . . . . 1824

A Young Woman of Poli .

Isadas-Plutarch's Life of Agesilans

View on the Tiber

Wr. Hlillips

182.5

1Tr. Ellames. . . . . 1825

Duke of Deconshire . . . 1826

Ilr. Harden . . . . . 1826

Mr. D. Baillie. . . . $182 \pi$

Ir. Ellames . . . . 1827

Duke of Bedford . . . 1827

Mr. Harmen . . . . 1827

Dr. Jenks. . . . . 1827

Earl of Leven and Hetrille . . 1828

Dh. Nott . . . . . 1828

Sir Jolen Soane . . . . . 1829

The Cave of Despair. . .

Pcasants Returning from Labour (half figures, life-size)

Ifr. Harman . . . . 1830

Contadina Family, Prisoners with

Banditti

1\%. Banless

1830 
SUBJECT.

FOR WHOM PAINTED.

WHEN

FINISHED.

Hagar and Ishmael.

Doposit pieture at Itoyal

Head of a Peasant Girl. Academy

1880

Peasant Woman Fainting from Bite of Serpent. Mr. Iryett

1831

Head of an Italian Peasant Girl . .

Portrait of Mrs. Semper . . . .

16. Sheepshanks. . . . 1831

Sir Matthew Ridley. . . 1831

1831

A Number of Greek and Italian Sketches

Mr. Ilarman. . painted in

1819

retouched in 1832

Portrait of Mr. Hammick _ . . Mr. Wm. Eastlake . . . 1832

Greek Fugitives . . . . . Sir Matthew Ridley . . . 1838

Portrait of Miss Johnstone . . . Earl of Essex . . . . 1833

Escape of Francesco Carrara. . . Mr. Morrison . . . . 1834

Head of an Italian Peasant (begun in

Italy) .

Dr. Nott . . . . . . 1834

The Martyr (St. Sebastian) (begun in Italy) Lord Tankerville . . . . 1834

Portrait of Miss Bury . . . . Lady Charlotte Bury . . 1834

Pilgrims coming in Sight of Rome, in opposite direction to before-mentioned picture . . . . .

Portrait of Mrr. Wingfield (half-length)

Portrait of Mr. Pattison . . . Family

Earl Grey. . . . . . 1835

Family. . . . . . 1835

Portrait of Mrs. Wickham . . . Mr. Wiekham . . . . 1835

Portrait of Mrs. Bellenden Ker . . Mr. Bellenden Ker . . . 1835

Two Long Pictures of Pilgrims . Marquis of Lansdowne . . 1836

Repetition of Pilgrims in Sight of Rome Mr. Moon . • • . . 1836

Pompeian Room . . . . . Mr. Bellenden Tér . . . 1836

Sketch of a Child's IIead . . . . Lord Ternon . . . . 1836

Sketch of a Turk (begun in Greece) . Sir Charles Bell . . . . 1836

The same . . . . . . Mr. Bellenden Ker . . 1836

Portrait of Miss C. Minshull . . . Frmily. . . . . . 1836

Portrait of Miss F. Minshull . . . Frmily . . . . . 1836

Portrait of Earl of Essex . . . Earl of Essex . . . . 1836

Eacus and Hesperie (begun in Italy) . Nr. Pupnorth . . . . 1837

Greek Captives. . . . . . Mr. II. He Connel. . . . 1837

Portrait of Rt. Hon. Charles Wood . Family . . . . . 1837

Portrait of Dr. Hammick . . . . Ftmily. . . . . . 1837

Portrait of Miss M. Minshull . . Frmily . . . . . 1837

Portrait of Miss Minshull . . . Family. . . . . . $18: 37$

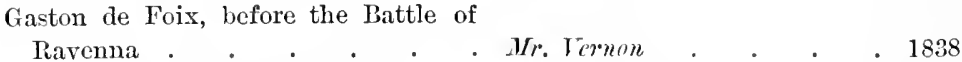

Portrait of Countess of Essex . . . Earl of Essex . . . . 1838

Christ Blessing Little Children . . Mr. Hells . . . . 1839

La Svegliarina . . . . . . . Wr. Whoon . . . . . 1839

Second Portrait of Miss Bury _ . Laly Charlotte Bury _ 1839

Portrait of Mr. C. Wingfield . . . Mr. Wingfield . . . . 1839 
SU BJECT.

FOR WHON PAINTEL.

WHEN

FINISHED.

The Salntation of the Aged Friar. . Mr. Moon . . . . . 1840

Portrait of Miss Wickham . . . Mr. Wiehham . . . . 1840

Pilgrims Approaching Rome . . Mr. George Viziun . . . 1841

Christ Weeping Over Jerusalem . . Mr. Smith Child • . . 1841

The Sisters . . . . . Mr. Fonnereau . . . . 1841

Repetition . . . . . Mr. Ternon . . . 1842

A Repetition, larger . . . . Mr. Marshall . . . . 1843

Hagar and Ishmael . . . . The same . . . . . 1843

Hagar and Ishmael, a repetition . . Mr. Carey, Lmerica . . . 1843

Sisters, a repetition . . . . Her Vajesty . . . . 1844

Subject from Comns, Fresco. . . H. R. H. Prinee Albert . . 184 t

Infant Genii . . . . . The same . . . . . 1844

Héloise. . . . . Lond Creve . . . . 1814

Subjeet from Comns (small oil sketch). Mr. Wethered . . . . 1844

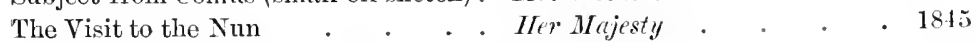

Subject from Comus, repetition in oil of Freseo subject . . . . . Mr. Mippislcy . . . . 1846

Contadina Family Prisoners, with Banditti, a repetition . . . . .

Portion of subject from Comus (a drawing) . . . . . . .

Sisters, drawing, a repetition . . . The Dule of Northumberland . 1848

Helena . . . . . . Mr. Frederick Robinson . . 1849

Sisters, repetition . . . . . Miss Rogers . . . . 1849

Escape of Francesco Carrara, repetition Exceutors of Mr. Termon . . 1849

The Good Samaritan . . . . H. R. IT. Prince Albert . . 1850

Ippolita Torelli . . . . . . Mr.Bellenden Ler . . . 1851

Violante . . . . . Alderman Salomons. . . 1852

Boaz and Ruth . . . . . . Mr. E. Bullock . . . . 1853

Irene . . . . . . . Mr. Gambart . . . . 1854

Beatrice . . . . . The same . . . . . 1855

\section{EARLY PORTRAITS,}

\section{CHIEFLY TAKEN IN PLYMOUTH.}

Mrr. Cunningham:

Mr. Prideanx (two portraits).

Mr. Broughton.

Mrs. Broughton.

MIr. Arthur.

Dr, Bidlake.

Mr. W. Fox.

Mr. Hingston.

Mr. Lampen.

Mrs. Lampen.
His Mother.

His Father.

His Mother (unfinished)

Mr. S. Fuge.

Mr. Collier (two portraits).

Mr. S. B. Martin (half-length).

Mr. Childs (two portraits).

Old MIr. Fox.

Mr. Tanner. 


\section{E S SAY S.}


a 


\section{"HOW TO OBSERVE."*}

(AN ESSAY INTENDED TO ASSIST THE INTELLIGENT OBSERYATION OF WORLS OF ART.)

\section{FIRST CHAPTER.}

BEFore we endeavour to assist the intelligent inquire: "how to observe" in the Fine Arts, it will be desirable, consistently with the elementary plan proposed in these Essays, to consider the general nature of the arts, and to distinguish their essential and proper characteristics from their subordinate applications. Undoubtedly, the most strictly and literally useful employment of the arts is to be sought in their applications, and hence it is not surprising that some well-meaning writers should have dwelt on such utilities as the chief ground of recommendation. Such a mistake may be pointed out without necessarily undervaluing the useful capabilities in question; for we find that the arts have been at all times employed to the greatest advantage for the mere purposes of humble decoration, precisely when their highest power's lave bcen most complete, and when, consequently, there would be least danger of their not maintaining their dignity. In separating these widely different chims to consideration, it will be, therefore, so much the nore just to pay due respect to the merely useful department of the arts, inasmuch as they have generally been indications of the corresponding culture of their more refined attributes.

* The two following Chapters, thus entitled, were written in 1835. 
But among the chief applications of the arts to merely useful purposes, and one to which they were applied in the earliest times, may be mentioned the transmission of facts by representations which may be assumed to be addressed merely to the understanding, and not to the faculty of taste. Dr. Johnson is reported to have said that formative art could illustrate but could not inform. Yet a hundred instances might be adduced in which knowledge gathered from ancient works of art is obtained for the first time, and from them alone, which is the natural consequence of their speaking a language which all can understand. For while the arbitrary symbols of which written language is composed are totally without meaning until education has taught us to connect with them the ideas they represent, the plastic arts are immediately intelligible, and it is their universal language which sometimes enables us to verify the history of nations whose inscriptions have been preserved to us in vain. This immediate perspicuity or natural eloquence is, besides, one of their higher distinguishing characteristics, for, considered apart from the limited utility to which it may be applied, it could be easily proved that imitation, as such, is generally intelligible in proportion to its excellence. Had Dr. Johnson said that it is the lowest province of art to inform, and that it would be more consonant with its juster purpose-that of appealing to our higher sympathiesto abandon the inferior office of supplying the province of words, he would have been nearer the truth. He would also have found his notion entirely borne ont by the progress of the art among the Greeks, as distinguished from the Egyptians and Asiatics, which nations, by endeavouring to inform, often confounded imitation with written language, instead of addressing the feelings and the imagination by the exhibition of character and beauty with an effect which language can never approach.

The independent power of the arts to convey informa- 
tion rould be best attested by the antiquary. His chief interest, even in works of taste, is derived from the facts they communicate or establish; and so long as this is acknowledged to be a secondary interest it is no more to be quarrelled with than the useful researches of those who peruse an ancient poet for information respecting costume, geography, or any other circunstances with which to illustrate history. The use of the arts in corroborating or even, for the first time, suggesting explanations of passages in the classic writer's of antiquity has long been appreciated, and has often been resorted to with the happiest effect. The taste for such comparisons was most rife in this country in Addison's time, and the monument of the abuse of such research is Spence's Polymetis. The search after parallel images in classic poetry and sculpture led this writer gradually to confound the characteristics of the two arts; and to forget that the end he had in view might be equally answered by works that have no pretensions to merit. His misapprehensions are ably and indulgently exposed by Lessing, who does justice to the more successful conjectures; but Lessing himself, with all his acuteness, was signally unfortunate in attempting to explain the statue called the Fighting Gladiator by a passage in Cornelius Nepos. All this, however, need not bring discredit on those means of elucidation which ancient authors and antique works of art mutually provide, in which respect much remains to be done; and indeed it may be observed that an acquaintance with the sculpture and monuments of antiquity is almost essential to the student of the classics. In this way a taste for the finest examples of art might be gradually imbibed; but, it must not be forgotten, that for the mere purposes of information the most ordinary performance is on a level with the finest-the commonest cast with the original marble.

As handmaids to Science the arts were limited at first by the state of Science: still, the proof that such an applica- 
tion was not considered unworthy of the highest talent may be sufficiently apparent from the drawings of machinery by Leonardo da Vinci, by what we read of the researches of Pietro della Francesca, and by the varied labours of Albert Durer. Whether 'Titian furnished the designs for Vesalius' anatomy or not, Raphael disdained not to make topographical sketches of Rome, of which many are extant. The assistance which the arts have rendered to general knowledge, particularly in modern times, by the delineation of objects of Natural History and other branches of science, is perhaps the only form of imitation with which some persons are familiar; yet instances are not wanting in the Dutch school in which accurate transcripts from nature are accompanied by all that is exquisite in art. It may fairly be supposed that many of those works, representing not only Howers, but insects and reptiles, as in the pictures by De Heem, Van Kessel, and others, although entitled to be ranked anong works of taste from their employing all the machinery of effect, were more especially interesting to the naturalist, and probably were at first chiefly encouraged by such amateur's.

The connection in Holland of this branch of art with Science is indeed apparent from various circumstances. Without staying to give Houbraken's description of the curious menagerie of the Marcellis, it will be sufficient to mention the ardour of Maria Sybilla Merian, who undertook the voyage to Surinam expressly to design the insects of the country. The volumes which she published on her return have been classed among the finest works of their kind.

In another branch of art, that of landscape painting, it must be admitted that it has been reserved entirely for modern times to cultivate its useful applications, without endangering its more tasteful pretensions. 'The topographical department of landscape painting, to give it the humblest name that has been applied to it, can hardly be traced beyond 
the early part of the last century. Not only the great landscape painters, but eren the earliest Italian and Flemish artists, with all their timidity and accuracy, seem studiously to have aroided the representation of real scenes, and sometines appear to have been little anxious even to preserve an air of probability : this is seen in the backgrounds to some of Leonardo da Vinci's works,-borrowed perhaps from similar inventions of the cotemporaries of Memling and Van Eyck, - and in the later extrayagant combinations of the Panl Bril and Brenghel school. It may be here remarked as a singular fact that the style of landscape painting in Italy was, to a comparatively late period, if not from first to last, derived from the Northern Schools. 'The account given by Titian's biographers of his having taken certain German landscape painters into his house, to learn their style, is confirmed by the fact that the forms of his common buildings are always German, and such as are not to be net with in the Italian Alps.

Again, Denis Calvert, a Fleming, was the founder or reviver of that style of landscape which was practised by the Carracci and Domenichino. It would be digressing too much at present to trace the styles even of Poussin, Claude, and Salvator Rosa directly or indirectly to a Northern education or influence, but it will sufficiently corroborate what has been said, to remember that the landscapes of Claude, remarkable as they are for the air of general truth and probability, scarcely ever pretend to be real riews: we find in them the rums of Rome transported to the sea-shore, and the features of Leghorn and Genoa blended with those of Tivoli. The Dutch imitator's of Claude assumed a similar license, and the introduction in their pictures of well-known monuments betrays the liberties taken with the local accompaniments. These imitations soon ceased to be satisfactory, and, as usnal, novelty in any shape was eagerly welcomed. Instead of sun, space 
and air" instead of the "breezy call" of morning, or the still evening glow-the forms and circumstances of a particular spot-representations whose interest only began when the name was known - were gradually introduced. This new direction of an important branch of art was no donbt greatly owing to the taste for antiquarian researches which was carried to a sort of mania in Italy about the middle of the last century. At a time when Winclielmann directed the attention of the world to the remains of Greek sculpture, and expatiated in the language of enthusiasm on the highest efforts in art, the kindred inspiration which is the soul of landscape painting in common with all other efforts of art, seemed to be threatened with extinction.

The common sense of the view-painters addressed itself, howerer, to many; and with no other recommendation than a scrupulous accuracy of forms the art was considered to occupy a useful place as an appendage to geography and history. But this mere fidelity of delineation which the explorer of classic localities especially required, unfortunately long continued to be the limit of the artist's aim : it was perhaps carried to its absurdest extreme, at least occasionally, by Hendrick van Lint, who is mentioned by Sir Joshua Reynolds, his contemporary in Rome, as having acquired the name of "Studio" by copying every leaf on a tree. Even the best of the foreign landscape painters, who visited Italy, like the Prussian Hackert, gradually sunk into mechanical copyists of scenes which could indeed only be degraded by this merely topographical taste. It is necessary to remember this tendency of Continental art at the period in question, to be aware of the great value of such styles as those of Wilson and Gainsborough - the auspicious harbingers of English landscape : and it is but a just and merited compliment to this country to say that in the hands of our landscape painters the useful capabilities of art, howerer extensively cultivated, 
have never been suffered to superserte its more tasteful attributes. On the other hand it must be fairly admitted that when Titian painted the grandest landscapes the world has seen, and when the uses of engraving had been fully appreciated, there were no views of Greece, Egrpt, or India to instruct and relight the enquirer after knowledge. Raphael, we are told, sent artists to Greece to make drawings from the remains of antiquity, but the aspect of the country was never thought of, and an idea of the trash that was produced in the way of topographical illustration, may be gathered from the bird's eye views of cities which are painted in fresco in the upper Loggia of the Vatican.

The information which the arts now communicate, from the humblest engraving, to the Panorama which places us in scenes which no description could so well convey, will hardly be disputed by the most zealous adrocate of the taste of the sixteenth century. In general, that taste was Taste as distinguished from Utility; its humbler applications were only humbler decoration. The arabesques of the Roman villas-the frescoes in the extensive buildings of Florence-the paintings on the Urbino earthenware-the frescoes in the open air in Friuli, were all graceful redundancies of the arts of elegance; in landscape, however, it was reserved for modern times to attempt to satisfy the naturalist and botanist without departing from the grand or delicions impressions of general nature. It is well known that, with the exception of an occasional pine tree, the trees of Claude are scarcely distinguishable in their species; the same remark applies still more to Poussin, and to the Bolognese painter's; and if Salvator Posa loved the broad leaves and masses of the chesnut tree it was more because it suited his touch, than from any particular attention to sylvan accuracy. It would be difficult to call any other tree of his by a name. In short, the rarieties of the grove 
in some Italian and Italo-German landscapes of the last century may be considered altogether a modern invention. Had we had no other evidence of the cypress and olive, the fig-tree and vine, than such as the finest specimens of landscape painting that ever were produced give us, we could never have guessed how they abounded in Italy. But that the landscapes of Titian and Claude are the finest the world has known has been confirmed by the verdict of all who seek in a picture not a mere catalogne of Nature's productions, but a reflection of her larger impressions and pervading charm-impressions and charm which the memory retains, and in which the details more fitted for verbal description are merged. The literal imitation by the painter of many things which, strictly speaking, were not only visible but prominent, would destroy the spell of a remembered scene. For there can be no doubt that our memory of Nature is composed of general ideas, - of a sense of a whole,- - and art must be generalised to meet these ideas. It would be in vain for one who had felt the influence of the freshmess of moruing, the stillness of noon, or the glow of evening, in some enchanting scene, to hope to renew his delight by inspecting an accurate transcript of all the trees and plants indigenous to the spot, or such a portrait of rocks and soil as would satisfy the geologist. And if such a representation would be uninteresting (notwithstanding its special merit as an aid to Science) because it failed to realize the remembered sources of delight, so any treatment away from the desired impression would only proportionally weaken that impression. For it is not any particular feature of Nature but a ruling and master quality which appeals to the imagination, and the accumulation even of excellence which does not minister to that quality is only so much deducted from the pleasure of the imagination. And it is scarcely necessary to say that this ruling and master quality varies not only with the character 
of the scene, but with the feelings of the individual artist. Titian, as a landscape painter, aimed, above all at integrity of local colour; Claude is the very type of the serene Italian atmosphere; with Nicolas Poussin grandeur of form and composition was the leading aim; with Salvator Rosa "ideas of desolation, solitude, and danger;" - with Rembrandt the magic mystery of chiaroscuro. Each of these may be said to meet the taste of a class of beholders, and that beholder will have imbibed most of Nature's highest teaching who looks to these great masters for a leading and central inspiration, and not for the information which mere accuracy of detail can impart. But where this accuracy is introduced, without any sacrifice of the painter's principal object, he will not fail to do it homage.

It may here be asked how the view hitherto taken affects the claims of another important branch of art-viz.: that of portrait painting. It may perhaps be urged that the value of the work in this case is mainly owing to the information it gives as to the personal appearance and physiognomy, it may be, of a celebrated individual, or to the stronger but less extensive interest attached to the representation of one endeared to the spectator by more familiar associations. In both cases, however, these ends might be answered by varying degrees of merit in all that relates to the essentials of the art. But without the stamp of excellence, as concerns the means, the historical portrait would be merely an historical illustration; while, in the case of the more confined and less enduring interest of private feeling, a portrait would cease to have value in any eyes when those of affection could no longer contemplate it. On the other hand, if once invested with the perfections of the art, the portrait for ever asserts its dignity ; and this claim is found to supersede the loftiest pretensions as to name or history. The portrait of an unknown and even ill-faroured individual from the hand of Titian, Vandyck, or Reynolds, is more valued than 
a work, recommended by no matter what historical interest, which is deficient in the attainable excellences of the art. And it was precisely because beanty of form and agreeable accessories were seldom at command, that the greatest masters in this department seem to have felt the necessity of more than common attention in the points which depended upon their own skill. The more unpromising the forms the more these painters seem, as in the instance of Rembrandt, to have aimed at redeeming them, and making up the sum of beanty and interest by the refinements of colour, chiaroscuro and expression. 'These, it must be remembered, are essential and proper excellences of Painting, and thus the art is raised by raising its characteristic attributes.

It may be dangerous in a school where correctness of drawing is said to be not enough appreciated, to venture to assert that the abstract beanty of form which is impossible in a portrait is ill adapted to the art of painting generally. But when it is remembered that this perfect conformation is precisely the excellence which belongs to Sculpture, it must be evident that it camnot constitute the strength of the rival art. In fact the charm of physiognomy and expression begins with the accidents of form, and was therefore of necessity inalmissible in those higher regions of beauty which the Greek sculptors justly placed above the atmosphere of the passions. Again, were a high degree of beanty of form excluded from Sculpture, that art would have no other beanty left to it, except that of its material. Whereas in Painting, while the touching realities of character may be safely employed to address the feelings, the fascinations of gradation and contrast, and the general treatment of chiaroscuro and colour, which attract the general eye of Taste, still remain in reserve to win the imagination. It is in these last attributes that the beauty which painting contemplates chisfly resides; and it is 
important to recollect that they are compatible with every subject. Even when a dignified end has not been kept in view, the perfection of the means has never failed to secure lasting apluobation. Examples in the Flemish and Dutch schools will readily occur to every one, where the most ordinary forms and circumstances are recommended by a charm of colour, a skill in composition, and a management of light and shade, which are at once true to the style of the art and to the largest idea of nature; and which are sometimes sufficient, as in the works of Cuyp and Rembrandt, to excite the most pleasing and eren the grandest impressions. 


\title{
"HOW TO OBSERVE."
}

\author{
SECOND CHAPTER.
}

IF in the preceding chapter the highest claims of the Fine Arts have been shown to be distinct from any subserviency to the objects of Science, it must be remembered that in the opposite case, where Science is subservient to Art, the connection of the two is desirable and indispensable.

Knowlerlge of various kinds is in fact essential to the artist, the comnoissenr, and the general spectator, for the practice, the criticism, and the enjorment of works of art. It is perhaps eren more ostensibly the groundwork of interest in the case of the two last, than a source of any professed claim to approbation in the artist. For all Science which relates to the practice of the arts is supposed to be concealerl in its result; that result being an intelligible and impressive imitation of nature. A thorongh acquaintance, for instance, with anatomy is calculated to enable the artist to make his figures more intelligible; and whenever it is so ostentationsly displayed as to have a contrary effect (for this is quite possible) it is obriously misapplied. The office of Perspectire, again, is to render forms and relative distances correctly, and hence, when successfully. employed, it is least likely to attract attention for itself, still less to present appearances which are mlike nature. It is the same with every department of art which may be in any 
way regulated by a directing theory ; for not only sciences like those just named, which are more simple and certain in their laws, but those vaguer principles which relate to composition and grouping, to the management of light and dark, and the arrangement of colours, are all calculated to assist the full and effective imitation of nature, and can never be admitted to be judiciously employed miness they serve that end. It is justly remarked by Sir Joshua Reynolds, alluding to Du Fresnoy's r'ules, that no l'ules can make any pretension towards imploring nature, or going contrary to her work; their tendency is merely to show what is truly nature. But in addition to the theory which is foumded on nature, and which, of colurse, is common to all the arts, there are principles which lave reference to the methods of each art for itself, and which dictate the modes $i_{n}$ which it can best and most successfully accomplish its object. Many practical contrivances are derived from the requirements of the material, and from the maroidable conditions of the particular art; to say nothing of the modifications of treatment from situation, light, dimensions, or any peculiar application. The translation which Nature of necessity undergoes more or less in imitation generally, and in each art according to its means, will be considered hereafter.

A scientific acquaintance with the materials with a view to securing the beanty or permanency of the work is nudoubtedly of importance. The sculptor still finds it necessary to attend to the most accurate chemical details in the composition of lis bronze; and, in the infancy of oil painting, the same kind of knowledge was a part of the painter's studies. Tn more modern times the profession is generally content to leave these researches to others; but it sometimes lappens that an aphorism of Lord Bacon's is unconscionsly put in practice with the happiest results. "It is absurl to suppose," says the philosopher, "that 
things which have never yet been done can be accomplished except by means not ret tried." Whoever compares the extraordinary experiments of Sir Joshua Rernolds, recorded by himself, with the frequent indications throughout his Discourses of an intimate acquaintance with the Baconian philosophy, will be convinced that the above maxim was uppermost in his mind.

The connoisseur, as the name implies, is lie who more especially professes to linou. The designation perhaps indicates an acquaintance with facts rather than truths, with appearances and results rather than with their causes. In its general acceptation it comprehends a familiarity with the characteristics of epochs, schools, and individual masters, together with that nicer discrimination which detects imitations from original works. The chief distinction between the comnoissem and the amatem is that the linowledge of the first assists the exercise of the juclgment, while that of the latter tends to kindle the imagination. The studies of the connoisseur may, howerer, take a higher range, and be directed not only to recognise excellence in works of art, but to investigate the nature and principles of that excellence; in short, in addition to a practical and habitual acquaintance with specimens, and a discrimination of their relative claims, to penetrate the causes of the rorld's admiration. On the whole, therefore, he may be said to combine the riems of the philosophical artist with an erudition to which the artist seldom aspires. Indeed the enthusiastic lover of nature and of the poetry of art, whether professor or amateur, would shrink from the dry and uninviting researches on which a just and accurate decision on these matters sometimes depends. Tet their importance is unquestionable, as a few examples may show.

In periods of the highest development of art it has been found that the more antiquated methods have still been persevered in by many opposed to innovation, and hence a 
great diversity of styles, as if belonging to distinct eprochs, may really have existed together'. The merely tasteful critic, best shilled to decide from the evidence of the work itself, would in such a case pronounce an erroneous judgment. 'Thus the grmaler style of Tenetian colou'ing maly be said to have been carried to perfection by Giorgione, who died young in 1511, but there exist pictures in Tenice by Carpaccio and others, with all the indications of a style a century earlier, which were done some years after Giorgione's cleath; one of these adherents to the older style, Girolamo di Santa Croee, painted as late as 1548. Igain, the seulptures of the Parthenon were undoubtedly all executed at the same period; yet, if some of the metopes, formerly in its frieze and now in the British Musemm, had been found separately, and could be proved not to have belonged to the 'Temple, they would never have been assigned to one and the same time.

Again, the inseriptions on statues in many eases fix the date with more certainty than the style of the work; thus, assuming that the inseription on the celebrated 'Torso of Hercules is genume (and it has never been questioned) it follow's that the Seulptor Apollonius lived after the age of Alexander, because the form used for the omega ( $\omega$ for $\Omega$ ) aplear's first on the medals of the lings of Syria.

'The material of statues, again, is sometimes an unanswerable evidence which may be opposed to opinions of their style. If Dolomieu be right in asserting that the Belvedere Apollo is wrought in Carrara marble, it proves that the statue was done in Italy, and at at compatratively late period; this mineralogical fact was at first questioned by Visconti, but afterwards when the statue was examined at Paris, he no longer disputed it. 'The style of the hair' and drapery' led Flaxman to agree with Visconti in conjecturing that the statue was a copy from one in bronze. In 
venturing to particularise the original from which it was taken-viz., an Apollo Alexikakos (avertor of Evil) by Calamis-Visconti was probably mistaken, not only becanse the attributes were different, but because many classic anthorities agree in stating that Calamis-an early Athenian sculptor-was proverbially rigid in his style, and hence not likely to be the anthor of a work such as the Apollo.

The same consideration of the material assists the connoissem in gems, for, whatever appearance of classic style or antique character an intaglio might have, it would be contradicted at once by the fact of its being engraved on a material unknown or never used by the ancients. The shell (Cyprea), so commonly and so successfully used by the moderns for cameos, was perlaps never so employed by the artists of antiquity ; in like mamnes an intaglio on a Bohemian raby, wonld be thus betrayed to be modern. So the comnoissem in coins also has certain indications from the composition of the metal, and the inscription; sometimes of more importance even than the style of the design.

The above are instances where the consideration of facts which we assume to be indisputable, must affect decisions dictated by the mere consideration of the style and merit of the work; the instances of the opposite kind, where apparent fiacts are orerborne by the evidence of the work itself, and by the opinions of those skilled in this more difficult point, are quite as common. Pliny, speaking of the sculptor Phidias, says that he rarely worked in marble, but that he was reported to be the anthor of a marble Venus of exquisite beanty, which adomed the portico of Octavia in Rome. In the accomnt given by Santi Bartoli, it is stated that the Venus de' Medici was dug up in the Pescaria (the Portice of Octavia). 'This singular coincidence might make it probable that the celebrated Venus is the work of 
Phidias, especially as Gori * says that the actual inscrip)tion which ascribes it to an mknown artist, Cleomenes, is false. 'To all this the work itself is a sufficient answer, for', beantiful as it is, it differs essentially in its style from the accredited works of Phidias. The circumstance, however, of the Amorini on the support of the statue being an indication of a comparatively modern epoch (becanse Amor was furst represented as an infant in later times), night be answered by supposing that these were executed at a different time, as they appear to be by an inferior hand.

Again, Tasari states that Raphael left a picture, (supposed to be a Madomna), which he had begum in Florence, mufinished, and that the blue drapery, which was wanting, was painted by Ridolfo Ghirlandajo. Many a copy of more than one Madonna, with a due want of hammony in the blue drapery, has, from time to time, been bronght forward in vain; its pretensions on the score of the historical coincidence being uniformly set aside for want of the seal of Raphal's genius. There is no end to the disposition to resort to proofs of this kind, which are expressly calculated to deceive the unwary collector. The comnoissems of Venice never fail to point out the texture and joinings of the clotht on which the works of their countrymen were execnted, and eren the wood of the stretching frames"il nostro abete" - those of Venice (mulike the rest of Italy) being miformly of deal; but these indications of originality are imitated, as well as erery appearance of age, with most sncessful exactness; and numerous fiamds prove that the quality of the art itself is the safest ground on which the commoissem an form his juclgment. The Tenetian restorer's of pictures in the last century took

* Museum Elorentinum.

+ The finer kinds of cloth used in Titian's time, appear to have been woven in very small portions, so that seams frequently appear which would now be considered a defect, and which are pointed out as a proof of originality. 
extraordinary pains, in mending damaged portions of old paintings, to preserve the indications of the texture of the cloth, and an account of the mode by which they effected this will be found in Goethe's Works.*

We tur'n from the consideration of such uninriting details to that of the more pleasing province of the amateur, the sources of whose interest are to be songht in the imagination and feeling.

There can be no enjorment of works of art, nor of nature lierself without association; but it is important to distinguish the different modes in which that faculty produces its results. Associations maly be peculiar, and hence mily be confined to a few, nay eren to one individual; or they may be owing to that general cultivation and experience which are common to many. To a traveller on his way to Tenice, alive to the first indications of his near alproach to "the City of the Sea," no object is more likely to waken a train of reflections, connected both with the grave and gay attributes of the place, than a gondola, with its light form, fit only for quiet waves, its antique rostrum, and its roofed and curtained stern. Yet the following associations were excited by this characteristic object in the mind of a Poet and Philosopher. "As the first Gondola approached, I remembered an early. plaything of my childhood, which I had not thought of for perhaps twenty years. My finther had a pretty model of a Gondola which he had bronght with him from Venice-he valued it much, and it was a great treat for me to be allowed to play with it. The first rostrum of polished iron-the black, covered part of the Gondola-all greeted me as an old acquaintance. I enjoyed a long-forgotten pleasant impression of early life."

Almost every biograplyy contains instances of this kind ; such accidental associations, like much that belongs to " Vol, xxxix. 
individual feeling, are often incommunicable, but where they are general enongh to be understood, they are sometimes capable of awakening the liveliest sympathy. The distinction above alluded to is observable in the impressions produced by worlis of alt; and, however powerful the more peculiar associations may be, they are not to be confounded with analogies essentially belonging to the object, and to which all observers may be more or less alive. The following is an instance where the effect of association must have been confined to the narrator. "Among other pictures I still remember with emotion a surpassingly well painted figme of St. Sebastian, bound naked to a tree. All angel draws the arrow ont of his breast, and another angel brings him a erown of flowers for his head. Even now I can hardly bring the picture strongly to my recollection without tears." In this case it is true the subject and expression of the picture itself were originally the cause of the enotion it excited, but the subsequent interest was owing to the memory of this impression. Is a specimen of a more generally intelligible and communicable kind of interest, Cowper's lines on sceing his deceased mother's portrait may be referred to.

Such associations, as the result of mere experience, may obviously be felt as strongly by the unlettered as by the best instructed, and hilppily, in the enjoyment of nature, experience is often sufficient, without any other condition than leisure, to induce the train of reffection which is both the cause and effect of 'liste. But it is not to be taken for granted that this kind of enjoyment cam always be experienced by the same chass of spectators in contemplating the imitative powers of an't. 'That it may sometimes be the case, ats for instante, in the landscapes of Clande, in the expression of the human countenance as rendered by Riaphael, and in the fimilian incidents of the Duteh and other sehools, seems quite possible, lint in works where tlee 
art itself has not so entirely concealed its means, a certain acquaintance with its conrentions is necessary: where also the scene or the incirlents of the subject are not familiar the spectator will naturally find lis interest increase with his general knowledge. This is equally apparent in the contemplation of the external world, in cases where tradition or history supply or heighten the impression.

Two celebrated deseriptions in this spirit will occur to the chassical reader-the reflections of Pogsio Bracciolini on viewing the remains of ancient Rome from the ruins of the Capitol; and those of Servius when he tries to console Cicero for the loss of his danghter by alluding to the destruction of the flourishing cities of Greece.

And who, in contemplating the monments of ancient art, does not feel low greatly their interest is increased by the thought of what they have sumived? Who is not willing to yield to the influence of inagination in reflecting that some of the rery statues, bas-reliefs, and eren engraved gems and mosaics, described by ancient writers, have been recovered after many centuries, and often from the bosom of the carth. A bas-relief in the purest Greek style, representing a philosopher reading, was dug up from the ruins of Cicero's 'Tusculum villa ; and in many of his letters to Atticus, we find him desiring his friend to spare no expense in collecting and sending lim such monuments of Greek an't as were fit, firom their subject and dimensions, to adorn " "philosopher"s Library."

The following passage is extracted from a letter of Francesco di San (iallo, (son of Giuliano the architect) in which mention is made of the first discovery of the group of the Laocoon.

"When I was first in Rome, being then very young, information was brought to the Pope that certain excellent statues had been found in a vineyard near S. Maria Maggiore. 'T'he Pope commanded a groom to tell Giuliano 
di San Gallo, to go instantly and see them. My father accordingly went, and as Michael Angelo Buonaroti was always at hand (being then employed on the Pope's monument, \&c.) he was invited to accompany us. We all went together, for I rode on the crupper behind my father. I descended to the place where the statues were-my father immediately said, "This is the Laocoon of which Pliny speaks.' February 28, 1567." *

Even with those who are skilled to judge of technical merits the interest excited by associations comnected with the history of the work, or its anthor, often rivals the impression produced by the subject or the treatment.

'Thus, howerer' disposed the artist or the comnoisseur may be to dwell on the merits of the picture of the Raising of Lazarus in the National Gallery, part of the interest with which even they regard it springs from an association equally accessible to the general spectator-the fact, riz, that it was painted in competition with Raphael's Trans. figuration, and under the partial direction of M. Angelo.

An anecdote related by Vasari has always given additional interest to the picture by Raphael, of Christ bearing his Cross, usually called "Lo Spasimo" (now in Madrid). It was painted originally for Palermo; the ressel which bore it was wecked, and men and cargo were lost; - the picture alone, being painted on wood, floated on the waves, and was at last recovered minjured in the harbour of Genoa. It was ultimately placed in the church of S. Maria dello spasimo at Palermo, "where," adts Vasari, "it has more fame and leputation than Momnt Etna." Incidents of this kind are by no neans without their influence even on those who are most alive to intrinsic merits, while with the ordinary observer they have the important effect of winning the attention till the merits are discovered. The appetite for associations of any kind must have been often observed in

* Miscellanea, dell' A rvocato Carlo Fea, vol. i. p. :399. 
those who visit picture galleries, and is as generally met and ministered to by the descriptions of guides and guide books. Nothing is more common in the absence of worthier grounds of curiosity than to dwell on some exaggerated incident comnected with the execution, or the vicissitudes of the work; or on some story proring the rast estimation in which it has been held; as for instance the offer of a wealthy admirer to purchase the picture by covering it with gold coin. Eren such associations which are only dwelt on for want of better are sufficient to awaken wonder and extort an empty admiration.

The classes of association hitherto alluded to may be traced directly or indirectly to Experience-an acpuaintance with facts observed by ourselves, or assmed or recorded by other's. There is another class which powerfully inlluences our impressions, riz., Authority-the experienced or recorded opinions of other's. A grand or beautiful scene in nature may be invested with new charms by the recollection not only of the events that occurred in it or the names that consecrate it, but by calling to mind the opinions of men of taste respecting it. Whether it be Tivoli, maised by Horace; or the Lago di Gardal by Catullus; or Cintra or Termi by Byron, we camnot help almiring the more because such men have almired before us. In like manner no artist, or man of taste, howerer skilled to judge, or even disposed to criticise, ever looked at the bronze door's of the Baptistery at Florence without being influenced as he recollected the reporterl exclamation of M. Angelo that they were worthy to be the Gates of Paradise. Yet no single authority, howerer imposing, can be so safe or so convincing as that of many; nor has even this concurrence its utmost weight till it is ratified by 'Time. This last kind of authority has perhaps the nearest "ploroach to truth which many questions relating to Taste almit of. 
In reviewing the foregoing distinctions-and examples to illustrate them might be multiplied without end-it will easily be seen that the associations of individual experience appeal chiefly to the fectings-the associations derived from Tradition and History kindle the imagination, and those founded on authority bias the judgement. All undoubtedly produce their influence in the first instance throngh the imagination, though the provinces of each are frequently found to be interchanged and blended.

Thus without limiting the degrees of knowlerge which may add to the interest capable of being derived from works of art, it is quite clear that some mental preparation is necessary in andition to the exercise of the eye. The interest of the ordinary spectator is in short especially dependent on associations, and it is desirable that these should be analogons to the nature and character of the olject. For such an observer, therefore, a knowlerge of the history of the art, and of its criticism, the connexion of its epochs and styles with general history, and of course a sufficient familiarity with the subjects of representation may be pronounced to be indispensable.

Again, we have already seen that without some acquaintance with the general nature of the art itself, and with the aim of the particular school and even of the individual artist, both the mode of the imitation and the treatment of the subject must often disappoint the merely lettered amateur. It is as well first to point ont the more attainable means by which the ordinary spectator may acquire or improve a lrabit of observation, for it is the habit of observation which can alone lead to a sincere relish and eventually to a just discrimination of the efforts of art.

The curiosity and interest of the general observer are chiefly excited by the subject, and this being the case it would be well if he were to select for his attention those works where the treatment of the subject has been con- 
sidered the important aim of the art. A Scripture subject by Raphael or Poussin, by Bassano or 'Teniers, are very different things. The first corresponds with the general impression which everyone receives from reading the passage; - the second introdnces us to particular circumstances, true (we will suppose) to the time and place in which the event occured, but unknown to many. The last engraft the story on the particular circumstances belonging to their own time. Raphael meets the rague, but necessarily dignified conception of the reader by distinct, adequate representation. The information which Poussin gires us of the mamners of the ancients supersedes by a new aim the great end of producing by representation an effect equivilent to the description. Bassano and Teniers, howerer, by introducing modern instead of antique circumstances and manners, not only differ, like Poussin, from the ragneness of the rearler's impression, but, besides this, sacrifice all dignity, and approach the mean or the ludicrous. So great a mistake must seem unaccountable to the judicions observer, and the estimation in which such pictures are held will be equally mintelligible, till he discovers that in these cases the aim of the painter was quite independent of the story; that, having been a vehicle only for the display of exquisite skill in the art. For, as might be expected, these painters who are so careless about the treatment of the subject seldom fail to excel in the attractions of the art.

But the observer should be on his guard to detect this tendency when less pronouncer, for, in contemplating works the fame of which rests on technical merits, and which may be deservedly admired, it would be a great mistake to extend that admiration to the treatment of the subject, as is rery commonly the case. The question what and why we should admire in the works of a given painter is therefore most essential. For the present we assume therefore a class of 
works where the consideration and treatment of the subject are not neglected, but, on the eontrary, eonsidered as paramount in importance. Such works, particularly where the incidents are taken from well known History, or from Scriptme, address themselves quite intelligibly to the attentive spectator, and, like Nature herself, need nothing but obserration and reflection to comprehend and relish them.

The Cartoons of Raphael have been often and well described. Tet there has been searcely anything written, which the ordinary observer, however nuacquainted with art, might not have discovered for himself. 'This is not said by any means to undervalue the descriptions in question, but only to show that it is a mistake to suppose that any other conditions than attention and common sagacity are requisite to enter fully, as far as the subject is concerned, into the merits of these works. We take as an example the cartoon of Paul and Barnabas at Lystra, with a description founded on that by Fuseli. "The sacrificer is arrested in the action of smiting the bull by the gesture of the young man who observes Panl rending his gament in horror of the idolatrous ceremony his miracle occasioner. The miracle itself is present, for the man who had been so lately a cripple rnshes in with eyes fixed on the Apostle, and with hands clasped in grateful adoration; while it is further evidenced by a person of gravity and rank who lifts up part of the man's garment to examine his restored limb, and by this act attests him to have been the bearer of those useless crutches thrown on the parement before him." * The object of Riaphael being always to meet and fully satisfy the expectation of the beholder, it would obrionsly be contrary to such an aim to enter into the details of the dress, architecture, and manners of the place and period, for, in general, none of these things are uppermost in the mind of the reader. But where an ancient ceremony is a prominent part of the

\footnotetext{
* Fuseli’s Works, Trecture V.
} 
subject, as it is here, the attention is then forcibly directed to it, even though some of its details may be new and strange to the spectator. The ceremonies of the sacrifice here represented (taken as is well known from an ancient bas relief) are therefore unusually exact. Many painters have thought to improve on the general principle just alluded to by seeking, in such subjects, to represent every circumstance, as far as possible, with learned correctness. The consequence, howerer, is that the spectator is struck with these circumstances, and not with the event itself, and whaterer moral or resthetic effect the subject is capable of producing is thus weakened or superseded. When, again, as is often the case with Niccolo Poussin, the air of classical antiquity which he infuses into his rorks deserves to supersede the subject or its treatment, it is ralued as the best effort the Painter can give us, and in his case as the highest example of snch a taste. This distinction should not be forgotten, for the great aim of Raphael to embody and satisfy the rague impression which the imagination retains involves the necessity of the highest effort at grandeur, dignity, or beauty, and this regulates the treatment eren of the minor circumstances abore alluded to. For, if our natural feeling demands that the figure of an Apostle should be clothed with dignity, the endearour to satisfy this feeling becomes paramount to any wish to inform us of the literal truth in these matters, eren supposing it attainable.

The great principle of the art to which all this is referred is its proposing to satisfy the imagination of the mass of spectators by adequate representation, and all aims, apart or distinct from this simple but difficult one, may be suspected to arise from the temptation to take refuge in more easily attainable qualities. But if the grandeur of the original impression is generally owing to the ragueness which necessarily excludes all particular circumstances, it 
follows that of all such details, the mean, the trivial, and the ludicrous, such as are frequently introduced in Venetian and Dutch Scripture and History pieces, are the most incongruous. In general, familiar incidents are seldom allied to grandeur, ret it is safer to condemn them on account of any positive defects, than because they are familiar; for both the Greeks and Italians were in the habit of representing, in a modified way, the appearances with which they were surrounded when recommended by qualities fit for representation. Again, when the object is rather to address the feelings than the imagination, familiar incidents, individuality of character, the charm of physiognomy, and judiciously selected details, are essential requisites; and that all this may be kept quite distinct from the trivial or the ludicrous, the early Flemish Scripture pieces abundantly prove.

In the description above quoted of the Cartoon of Barnabas and Panl at Lystra, a stress is laid on the age, dignity, and rank of the individual who examines the restored limb; and it will be remembered that this circumstance, which gives validity to the character of the witness who thus attests the miracle, is not in the sacred story. The observer who discovers such strokes of genius shares as it were the judicions invention of the painter. Any man might have been introduced examining the limb, for it is evident, from the crutches being dropped, and from the man's action of gratitude, that he is cmred; but to select a witness so little likely to suffer himself to be deceived was worthy of a great master. This example will explain what is meant by the term Invention in the arts, and may be taken as a specimen of the original means which the painter resorts to, to meet the fuhness of the description ; for even where it is necessary to adhere closely to the story (as is always desirable in Scripture subjects) it will easily be seen that great latitude remains for the painter, and that his representation is not a 
tame trauscript but a translation of the words into his own very different language.

The following account of Paul preaching at Athens rests more on learning than on the general sagacity before alluded to, and though the enumeration and distinction of the philosoplhers is highly probable, the intention of the picture is less strikingly evident than in the case just mentioned. "Simplicity of attiturle invests the speaker with sublimity; the parallelism of his action invigorates his energy; situation gives him command orer the whole; the light in which he is placed attracts the first glance; he appears the organ of a superior Power. The assembly, though selected with characteristic art for the purpose, are the natural offspring of place and moment. The involved meditation of the Stoic, the Crnic's ironical sneer, the incredulous smile of the elegant Epicmean, the eager disputants of the Acarlemy, the elevated attention of Plato's school, the rankling malice of the Rabbi, the Magician's mysterious glance, repeat in londer or in lower tones the novel doctrine; but whilst curiosity and meditation, lond debate and fixed prejudice tell, ponder on, repeat, reject, discuss it, the animated gesture of conviction in Dionysius and Damaris amnounce the power of its tenets, and, what the artist chiefly aimed at,-the established belief of immortality." * Althongh this kind of learning is not so generally aimed at by Raphael on points admitting of more nniversal acquiescence and sympathy, it should be remembered that such circumstances are worthier of a great painter than an attention to particulars relating to costume and localities, because they suggest and afford scope for the varieties of human character. The supposition that Panl is dwelling, at the moment chosen by the painter, on the doctrine of the Resurrection, is more than probable, because that was the point in his discourse which most excited the doubts of

* Fuseli's Works, Lecture III. 
his andience. "When they heard of the resurrection of the dead, some mocked: and others said, We will hear thee again of this matter. Howbeit certain men clave unto him, and believed: among the which was Dionysius the Areopagite, and a woman named Damaris, and other's with them." If the above supposition be correct it accounts for the action of Paul, for we may suppose that his hands have been raised together', with the words " the dead shall rise," and the action of Dionysius expresses not merely surprise but sympathy with the action of the speaker. Such speculations sometimes, as in this case, only highly probable, at other times leading to the fullest conviction and a thorough comprehension of the painter's aim, open an ample field for observation, reflection, and enjoyment.

It was assumed that it is quite possible for a painter to be less solicitous to affect the spectator by the event he pourtrays, than to represent the costume, manner's, and localities which belong to such an event. The inferiority of such an aim to that of Raphael has been alrearly pointer out, but, this being taken for granted, it must in fairness be observed that the spectator who is alive to all the allusions with which such rorks abound, will find a pleasure in tracing them proportioned to the extent of the associations they awaken. The instance of Niccolo Poussin is the most remarkable of this kind that can be quoted; and althongh he addresses himself, when dwelling on the points in question, only to a few, and less to the feelings than to the erudition of those few, he is placed at the head of his class because the general and poetical air of antiquity he gives to lis works is still more remarkable than his literal fidelity to every circumstance. So evidently was this spirit of antiquity, rather than its mere facts, his object, that in strictly historical subjects belonging to the Pagan world, he never scruples to introduce River Gods and similar personifications. The mode in which he con- 
trives to reconcile the imitation of nature with these supernatural appearances, so that they do not shock by their absurdity, or appear incongruous, is one of his peculiar merits. 'The greater part of Poussin's works contain some circumstances which mark an antique period, or allude to an antique rite, and all may be said to have an antique air, whatever period they represent. As such allusions are addressed only to the erudition of the spectator, they are readily discovered in works of art by those who take an interest in them. To such persons the works of Poussin, Giulio Romano, Primaticcio, and others, open all the sources of classic associations, and in spite often of unattractive colour will always be contemplated with pleasure.

There are two distinct classes of works in which historical and especially Scripture subjects are engrafted on modern localities, manner's and costume-the early Flemish School on the one hand, and the Venetian, Flemish, and Dutch Schools on the other. In the early Flemish paintings the great object being to interest the feelings, the familiar incidents introduced are far from interfering with such an impression; on the contrary the simplicity of so unambitious a treatment quite accords with the pious and sincere character and expressions of the figures. The imagination is not addressed except in the department of colour, which, by its breadth and beanty, atones in a great measure for the too frequent meagreness of the forms. In the Venetian and Dutch Schools, unlike the early Flemish, there is no moral aim whatever-the principal object is to display those attractions of the art which especially appeal to the eye, and hence any materials which could answer such a purpose are indiscriminately employed. The delight which the appreciation of this technical perfection is capable of affording can only be gradually experienced. Here again the defects in costume and even in more important matters are not for a moment defended, but such defects being taken for granted, 
the works in question may be interesting even to the general spectintor; not indeed for what they are called, but for what they really are. Many historical and Scripture pieces by Paul Veronese and others of his school, independently of their more ostensible merits, are not uninteresting pictures of Venetian manners, so that by suffering the association to depend not on a preconceived standard but on the admitted aim of the painter, no school can be altogether deroid of interest; and when the subject is greatly neglected the real object to which it was considered subordinate, will gradually interest the spectator as it did the artist himself.

Next to the associations connected with the subject, it is quite natural that the history of the Painter should be uppermost in the minds of those who contemplate his productions. The personal history of any great master cannot fail to add a new interest to his works, for by these means the modifications of individnal character are traced in what profess to be illustrations of history or imitations of nature. Still stronger, in most cases, than the character of the individual, is the character of his age; and this is apparent not only in the direction which the art itself takes, but in the impression which it receives from religion, from politics, from literature, and from manners. To this must be added the influence of Place as well as that of Time; nor should even the history and the ricissitudes of the work itself, its original destination, its various possessors, its rarity, acknowledged excellence, and actual value be forgotten. The accumnlated associations thus afforded can inform a lifeless work of ar't with far-reaching thought; and although such knowledge is quite distinct in itself from the critical discrimination of technical excellence, which the habit of obserration must chiefly teach, it will undoubtedly lead to this, and be found to assist the acquisition of an independent judgment.

The first influence on the character of the formative arts which it is important to consider, especially at the time of 
their revival and perfection, was that of Religion. It will not be necessary here to enter into the consideration of the mutual assistance which the arts and the Catholic Religion afforded each other; whatever may be the opinion as to the extent in which eren the Reformed Religion may be benefitter by this alliance it is quite certain that art, if less exclusively directed to Beauty, must be at least ennobled and purified by such an application. In the early ages of Italian and Flemish art the expression of a soul-felt piety was the ruling aim and characteristic of the artist and his productions. Monlis and ecclesiastics, among whom the name of Fra Angelico will first occur to the reader, were among the most deroted professors, dividing their time between the duties of their calling, and the ontponrings of their enthusiastic feelings in the elaboration of altar pieces and similar works representing subjects from legendary as well as Scriptural sources. The effect on others of such sincere attempts to do justice at least to their own feelings camnot be donbted, and the docile piety of the age was met and exalted by such effusions.

Among the chief causes of this very general spirit, about and after the time of the revival of Art, was the impulse given to the more self-abasing doctrines of Christianity by the rise of new and severe religious Orders. The character of the early school of painters in Umbria, which had ultimately more or less influence on the schools of Rome, Florence, and Bologna, may be traced to the influence of the doctrines of St. Francis; but even at a later period, in the lifetime of Fra Angelico, the tendency of the age to the same enthusiasm must have been very decided, for we find that a number of ultimately beatified and sainted persons lived at or near the same time.

The earlier works which are remarkable for the impression alluded to, are imperfect in the extreme as productions of art, and, but for the interest comnected with the abore 
fact, would often be passed over withont a second glance. On nearer inspection, however, and with due allowances for the technical imperfections of the age, the feelings of the human beings of that time will still be apparent in spite of the defects of the work. Malvasia relates that the celebrated painter Guido, so remarkable for the delicacy of his taste, and of all men the most likely, from the masterly freedom of his pencil, to despise the tame and defective efforts of the early painters, was seen to contemplate with deep attention a Madonna by Lippo Dalmasio, and at last expressed his opinion that none of the then living painters conld infuse into a countenance such an expression of holiness.*

Instances were not wanting, even from the earliest periods of the revival of art, of painters who were intent on the display of the art for its own sake; and as imitation gradually approached its highest perfection an ulterior object was naturally less and less kept in view. With the character of the art the spirit of the age had changed, and it would perhaps be universally admitted that at and immediately before the period of the Peformation the examples of enthusiastic piety were less frequent in the Catholic Chureh than they had been a century earlier. But there was another important cause which gave a new bias to the style of the arts, a bias which has lasted very generally to the present time. This was the inerensing taste for classic literature, and the discovery of, and growing admiration for, the antique statues. 'To this subject we shall hereafter' return.

Thus Raphael appears to be the point immediately preceding a remarkable change in taste, and this would appear to be true in other respects; for while, owing to his education under Pietro Perugino, to his early associations and his own feelings, he never abandoned the moral aim of the older painters, he supplied their technical deficiencies by the

* Felsina Pittrice. Vita de' Pittori Bolognese, vol. i. p. 26. 
gradual attainment of a perfect style of imitation, and even infused the breadth and beanty of the antique into his works without losing sight of the qualities that touch the heart.

But the spirit of early Christian art was not only in danger of being amihilated or superseded by the influence of this classical taste, but also by the perfection of the art itself. When we consider the peculiar education of the mind as well as that of the eye and hand which are necessary to produce anything approaching excellence in art, it is not to be wondered at that its high attaimment should be considered in and for itself a sufficient aim for human ambition. And this will appear the more admissible when it is remembered that, as an imitation of nature in her largest impressions, the art is capable of conveying in a condensed and abstract form all those otherwise inexpressible and uncommunicable feelings which the contemplation of the visible world excites. It is quite natural then, that, when perfectly accomplished, this form of Poetry (distinct from Poetry properly so called) should no longer be considered as a means, but as possessed of independent claims and qualities. If Nature herself, it may be urged, has no distinct method of instruction, but only exalts the feelings by a language which no other language can approach, why should not the colouring of Titian or the forms of the Apollo be permitted to exercise their own eloquence without being made subservient to any ulterior purpose? Langnage, it may be added, can tonch the feelings not only to a greater extent but much in the same manner as the formative arts, by an attention, namely, to interesting particulars; but the power of arresting the indistinct images of grandeur or beanty which every imagination gathers from nature belongs to the arts of design alone. Thus employed they appeal chiefly to the imagination, and in the rery vagueness and generalisation which this implies, abandon as an inferior if not incom- 
patible aim the comparatively humble office of touching the feelings.

Such is the view or the tacit impression which may explain the production of those works that exemplify the exclusive triumph of the art, and which gradually led to the subordination of all aims to that of its own display. The departments of art which were carlied to perfection in Italy varied in different places, and in different hands, though all coincided in time. Form was the favourite study of the Florentines and of M. Angelo-colom was carried to perfection in Venice by Titian-gradation of light and shade in Parma by Correggio. It is not to be supposed that the general tendency of this technical perfection excluded in every case the attempt to appeal to the feelings as well as to the imagination; yet, in the accomplished productions of MI. Angelo, Titian, and Correggio, grandeur or beauty are the predominant characteristics, and the style of their works is the more striking precisely because it is more partial and exclusive than Raphael's. On the other hand, in comparing the great painter last named with the early Flemish masters, his superiority will appear to consist precisely in the greater beauty and grandeur of lis designs, and in his having attained these high qualities without losing himself in ummeaning generalisation (the very possible tendency of such an aim). The union of physiognomy with beauty or dignity, of the truth of nature with imagination, of a sufficient attention to particulars with grandeur, constitute one of the chief and umrivalled elements of Raphael's fame. It is true the early Flemish painters unite beauty and breadth of colour with individuality of form, and where these forms and details are not repulsively defective and minute, as is too frequently the case, this mion may be granted sufficient to maintain the independence of the art; but the mode in which Raplael accomplishes the same end is far more satisfactory and complete, especially where, as 
in some of the frescoes of the Vatican, the colouring is on a level with his other excellencies.

The religion of Enrope in the earlier epochs of Christian art affected not only the general spirit of that art, but its particular inventions and customary treatment. Private families in dedicating altar pieces had the triple object of paying homage first to the Madonna, who may be considered in some of these cases to represent the Chmreh, then to their patron Saints, and lastly of confessing the faith in their own persons by the introchuction of their portraits in the same picture. Again, such pictures were offered to acknowledge particular benefits, escapes from danger, disease, or death; the presiding Madoma, the Saints who protected or interceder, and the living and grateful objects of their care thus appear together, and the "grace received" is indicated either by a specific allusion or by the attributes of the particular Saints introduced. A very slight acquaintance with this practice will soon accustom the admirer of art to allow for the anachronisms of these rotive pictures, and he will gradually be smitten with the simple sincerity of such representations. The portraits of the donors always appear dram with strict fickelity, even to their clothing. It will be seen too that this anachronism, by which the painter's contemporaries were introdnced, as it were, into the societr of beatified personages, led by an easy transition to the representation of Scripture subjects without altering the morlern costume. The effect of this in an enthusiastic point of riew must have been great, for the mass of beholders contemplated the high examples here depicted more as realities, and were thus invited to mingle in idea with the saints of old.

To return to the rotive pictures, properly so called; in many instances the patron Saint presents the family to the Madonna, as in Titian's picture, called the Madonna de' Frari. Sometimes the Saint even points ont of the picture 
as if interceding for the spectator; this seems to be the action of St. Francis in Raphael's Madonna di Foligno, and it is so, beyond a doubt, in that of St. Sixtus in the Madonna at Dresclen by the same painter. In this last instance, the Saint's intercession for the spectator seems the more natural becanse there are no votaries in the picture. The composition of the group in the earlier altar pieces, whether "ex voto" or not, was always semi-circular, as if to mix up the spectator with the divine or sainted personages represented, and to make him feel himself to be in their presence. This arrangement was never abandoned by Raphael in devotional subjects: in mere historical or dramatic compositions, in which the spectator might be interested but not a party concerned, Raphael adopted the more picturesque arrangement of disposing the nearest figures with their backs turned to the front of the picture, thus approaching the circular instead of the semi-circular form. The two modes may be seen occasionally in the same picture, where the lower part represents an ordinary action or' story, and the upper part a vision, as will appear by comparing the scene of the Transfiguration in Raphael's picture of that subject with the group below. Again, in his Theology, commonly called the Dispute of the Sacrament, the figures in the human group are arranged in the more picturesque method, while the Synod above is semi-circular. The succeeding painter's, who were on all occasions intent chiefly on the excellence of the art as such, frequently adopted the picturesque form even in devotional subjects.

It is to be remembered that the attachment to particular Saints naturally varied with time and place, and the influence of this on the practice of the art is worthy of attention by those who trace its styles. The nude, or only partially draped figure, abounded most among the rural and local saints belonging to the Venetian territory; where, for instance, St. Sebastian, St. Roch, and St. Christophe1" 
protected men and cattle from wounds, disease, and lassitude, or renewed their strength when overeome with labour. The study of the colour of flesh was thus early practised on a large scale by the Venetian painters.

The extent of the influence of St. Francis round Assisi,the centre of his spiritual dominion, and the place of his death,-is defined less by actual distance than by the facility of communication as regards the Apemmines. Foligno, Perugia, Urbino, and Bologna belonged in the time of Raphael's youth to a school of art especially accustomed to represent the local Saint, and a facility in the treatment of thick and ample drapery may have been the consequence.

Another class of anachronisms may be mentioned in such pictures as Raphael's Heliodorus, in which, thongh the story is taken from the Book of Maceabees, Pope Julius the Second, with his attendants, is introduced. Many of the subjects in the Stanze of the Vatican, although sometimes taken from Scripture, and generally intended to exhibit the protection of Heaven extended to the Church, are contrived to afford allusions to incidents in the life of the reigning Pontiff. Thus the deliverance of Peter from prison alludes to the escape of Cardinal Giovanni de' Medici, subsequently Leo $\mathrm{X}$., after he was taken prisoner at the battle of Ravenna. Again, the wars in which Julius engaged had so exhausted his treasure that his allies, in order to secure their promised subsidies, threatened to strip the churches, and even St. Peter's itself. This suggested the subject of Heliodorus; and the Head of the Church is introduced witnessing the infliction of divine rengeance on the sacrilegious invaders.

The influence of religion on the spirit and style of art itself is a very different consideration from the mode in which it may affect the employment of artists; yet as the nature of that employment may be reckoned among the causes which led to the excellence of the great Italian 
Painters, it would be an omission not to allude to the check which the arts of our own comntry received by the Reformation. 'Ihis sulject has been well handled by Flaxman in one of his lectures, , and although what he states has more reference to Sculpture than to Painting, there can be no doubt from the proofs he adduces that, at the period in question, this country bade fair to compete in art with the great schools of the Continent. The extinction of this promise was the immediate consequence of the Reformation, which had the effect of excluding pictures from churches, and the prejudice was revived and enforced by the Puritans a century later.

We allude for the present briefly to the influence of the Greek mythology on the arts-an influence the most direct and harmonious. The consideration of this subject is indispensable in order to comprehend not merely the allusions and mysteries of the mythologic personifications, which have been handed down to us in the monuments of ancient taste and devotion, but the principles which were common to the definitions of the artist and to a religion which sprung from, and may be resolved into, the abstract ideas of nature. This examination will more fitly accompany the portion which will be devoted to Sculpture. $\dagger$

The impression which the character of the art receives from causes connected with political relations will open new and interesting sources of inquiry to the cultivated observer. The personal history of the Pontiffs was illustrated, as we have seen, by incidents from the canonical or apocryphal books of Scripture. In Venice the "potent, grave, and reverend" Senate, the martial achierements of the Republic, and the opulence that resulted from a thriving commerce, appear alternately or altogether to vie with religion in impressing their character on the productions of the pencil.

* Lecture I. English Sculpture.

† See "Contributions," Essay VI. Sculpture. 
Such influences as we have thus slightly touched on are not confined to the choice or dictation of a subject, nor to the introduction of contemporary persons or erents, but pervade directly or indirectly the style and aim of the art itself-the materials of which have in a great degree always determined its character. The age of armour, while it invited attention to certain technical merits, and was farourable to picturesque efiect, may have had the effect of accustoming the eye, as in the works of the early Flemish painters, to rigidity of outline both in the figures and drapery, and, on the other hand, may have gradually opened the resources of chiaroscuro to correct this. The republican equality of Venice was symbolised by and perhaps confined to the unpretending black dresses of the Senators, but the introduction of these dresses in pictures once supposed, a rich and glowing scale of colour was likely to accompany it.

Again, it may be said of the style of Sculpture in Holland, that owing to the necessity of representing the circumstances of moderu warfare and the temptation to compete with the fuller means of Painting, the momuments to national valour (there almost all restricted to naval heroes) abound with various defects in style; for the rigging of ships, the sea, fire, and smoke are often rainly attempted in marble. Among the consequences of the French revolution also we not only find subjects representing classical examples of valour and patriotism, in accordance with the ostensible principles of the day, but the admiration of the rigid severity of Roman or Spartan virtue involved a close imitation of the antique Sculpture, and is to be recognised in extreme correctness of form and costume, with little else to recommend it. The change to a military despotism had the effect of forcing this classical hardness to invest itself with all the accidents and details of modern military circumstances. Thus the accuracy which had been the result of the antique mimicry 
was again lost. The new subjects, on the other hand, rarely lent themselves to the agreeable display of the art, and it was not till they ceased so exclusively to demand the labours of the pencil that taste by degrees returned to a healthier state.

It may not invariably be possible to trace a direct political influence where events have been less pronounced, but the change in the character of a state may be said to be always accompanied with its cor'esponding indications in the productions of art, especially where they are employed in a public form. The "senatorial dignity" of Titian is indeed always opposed to the light, festive chalacter of Paul Veronese; but in making every allowance for the diversity of individual feeling, it is evident that both are in harmony with their respective times. The heroic age in any nation is always found to precede the development of art, and so it was in Venice, but at the time when Titian attained that perfection which had been nurtured in the simplicity and solemnity of the early school, the government of Venice was at its acme of political influence. Half a century later the opulence of the State had reached the point from which it erer' after declined, - a period marked by the ostentations display rather than the thrifty employment of wealth. The evidence of this state of things is to be seen in the luxurious gaiety of Paul Veronese's style.

The silent working of causes similar to those just alluded to may always be traced, assuming a sufficient knowledge of facts; and even the occasional misconceptions of writers of authority should not deter the observer from indulging in such reflections. Madame de Stael ventures to assert that the expression of grief was never given to a Greek statuein short, did not exist in Greek art-before the time of Philip of Macedon; and explains it by supposing that the representation of a state of suffering was unworthy of artists 
living in an age of freedom. The assertion is erroneous, and the conclusion absurdly so ; but it is not without reluctance that the necessity of checking the exuberance of philosophic speculation is pointed out, for it is precisely the species of inquiry which is fitted for the lettered amatem, and which in his mind may frequently supply the place of that interest which the professor and connoisseur derive from the mere work of art. The change in Raphael's style, when he removed from the influence of the more ascetic school of Umbria to the cheerful intercourse of the citizen life at Florence, has been dwelt on with his accustomed acuteness by Rumohr; the meek, serious, and almost suffering expression of some of the great painter's earlier works disappears in the smiling Madonnas painted by him after some residence in the 'Tuscan capital.

A new sonrce of interest is open to the amateur in the consideration of the influence of literature on the arts. In what degree this influence has been salutary or otherwise it is not necessary here to pronounce; but the mere existence of such a connection supposes materials for consideration and inquiry worthy of every enlightened observer. In accordance with the restricted plan litherto followed, a few only of the leading examples will be pointed ont, and these will for the present be confined to modern art.

The first great impulse, independent even of the invention of printing, though donbtless accelerated by it, was the revived taste for the writings of antiquity. The studly of the classics long preceded the appreciation of ancient sculpture. The enthusiasm and zeal of Petrarch and Boccaccio in acquiring and imparting a knowledge of the Greek and Latin authors can hardly be said to have become diffused till a century after their time-riz., till 1450 ; - when the desire to collect specimens of ancient art was beginning to produce its lasting effects. These specimens were naturally sought for in the first instance as illustrating ancient history 
and poetry. Petrarch himself collected antique medak, and in a later age the renewed study of the classics led to a similar result. Poggio Bracciolini, born 1380, first collected busts; the interest he attached to them probably in some cases depending on associations. But by degrees he acquired a relish for the art itself, and sighed to possess entire figures. Thus the admiration of the antique did not originate with the artists; the application of the monuments of ancient genins to the pmposes of modern art ras only an ultimate consequence of general cultivation. The admission of this classic influence was not sudden; many artists remained true to the Christian types long after their brethren had been carried along with the general mania, while, on the other hand, some few anticipated the general march of taste towards Paganism. Tot to mention a classic rotary so ardent as Mantegna, it is known that Cosmo de' Medici, in forming his museum, found no prompter more zealous than the sculptor Donatello. Lorenzo the Magnificent needed no prompter; thoroughly imbued with the philosophy as well as the poetry of Paganism, he not only continued to add to the treasmes his father had left, but conceived the idea of educating the artists of his time to imitate and rival them, by opening the garden in which his marbles were distributed as a place of study. It was here that, among others, II. Angelo resorted, when a youth. The extent of the Medicean collection of antiques was undoubtedly greater than that of any other formed in the same age; the place itself where they were deposited may be said to have been surromded by an atmosphere of classic learning, for there the greatest scholars of the time were ready to impart instruction to the admirers of Homer and the rotaries of Plato. Tet this was not the only asyhm which Attic taste and the Muses of classic poetry and art had found; in the latter part of the fifteenth century there was scarcely a State in Italy which failed to acquire its share of 
praise for the endowment of unirersities, the encomragement of Greek and Latin professors, and the formation of Galleries of art.

Of the princes who emulated each other in this course, none, next to the Medici, are more deserving of notice than the Dukes of Urbino-Frederigo da Montefeltro, and his son Guidobaldo. And they are selected the more readily, not only becanse some of the best artists of the age were born in or resorted to their capital, but because the extent of their influence is maccountably orerlooked by the historians of art. The accomplished Baldassare Castiglione was for many years of his life attached to the fortumes of the Montefeltri: his Cortegiano, a book well known to every lover of Italian literature, professes to gire the model of a polished education as drawn from the "Accademie" or soirées of the court of Urbino in Guidobaldo's time. In introducing the reader to the society of great and accomplished men who met in the apartments of the Duchess, he describes the classic decorations of the Palace, and its "antique statues of marble and bronze." But the most remarkable record is a long manuscript poem on the acts of Frederigo, by Giorami Sanzio, the father of Paphael,* in which the description of the castle seems to justify the poet in conferring on Urbino the title of "the Athens of Umbria." +

* This poem was written either before Raphael was born, or in his infancy.

$\uparrow$ Tiraboschi (vol. vi. p. 7s) gives (perhaps as a literary curiosity, a dedication of a book to the Duke Frederigo. The author, or editor, Piero Perotti, tries to imagine what the sensations of his rolume will be when permitted to enter the precincts of the Ducal Library; "Al vedere ch' esso farà ivi ogni cosa risplendente di marmo, d' argento e d' oro, all' entrare in cotesta tua magnifica biblioteca, benchè mutolo e senza vita, parrà nondimeno che si rallegri ed esulti." "Tedrà quanto onori i professori d' eloquenza, con quanta degnazione accogli gli uomini dotti ; talchè sembra che gli studj delle belle arti, esuli prima e raminghi abbian per te solo ricuperata e la vita e la patria." Lastly, we learn from the same source that Frederigo not only was a hero, but looked like one: "stupirà al vedere la tua quasi sorrumana grandezza di corpo, la robustezza delle nembre, la dignità del sembiante. s.c." 
All this, it may be observed in passing, sufficiently proves how little ground there is for asserting that Raphael in his early youth was without the materials or the precepts necessary to form an accomplished artist; for, with the exception of Florence, no court of Italy, not eren that of Rome, was so well fumished with both as Urbino. Nevertheless, whatever influence the specimens of the antique sculptures there preserved, may have had on him, whatever direction his taste may have received from the works of Luca Signorelli, Pietro della Francesca, and other skilful artists to which he had access, it is quite true that all was superseded by his devotedness to the spiritual aim of Pietro Perugino,* and the Umbrian painters. That this was the result of a deep moral conviction rather than the mere blind force of example is proved by its being uneffaced by the examples of talents far more splendid;-in a word, if Raphael could afterwards live in Florence untainted by the classical taste which prevailed there, it is quite easy to conceive that all which Urbino contained of a similar nature might have sunk in his estimation if found to be incompatible with the aspirations of a Christian painter.

Both Florence and Urbino precerled Rome in the formation of Galleries of antiquities. Petrarch had indeed long before tried to araken an interest for the ancient monuments, and Rienzi shared his zeal, but a long indifference succeeded, and when Poggio described the state of Rome in one of his most interesting compositions, the could only enumerate five marble statnes and one of bronze. It was reserved for Leo $\mathrm{X}$. to excite a permanent interest for the sculptured relics of antiquity. The discovery of the group of the Laocoon was soon followed by others of equal importance, while the munificent rewards which the Pope

* According to the well grounded argument of lumohr, Raphael must have been nearly 20 years of age when he began to study uuder Perugino.

+ De Varietate Fortuma. 
offered stimulated a passion which requires no edncation. "The production," says Roscoe, "of a gennine specimen of antiquity secured to the fortunate possessor a competency for life, and the acquisition of a fine statue was almost equivalent to that of a bishopric." The taste of the Pontiff was shared by many who had imbibed it from the same sources-riz., from the courts of Florence and Urbino. Castiglione, the friend and adviser of Raphael, himself collected "antique busts and cameos of the best workmanship." ** Nany of the Cardinals expended their treasures in similar objects, but the individual who formed the most extensire and rarious collection was Antonio Colocci. His villa, near the remains of that of Sallust, might be compared with the garden of Lorenzo de' Medici at Florence, and, like that, was probably open to the students of antiquity and art.

Thus, it is erident that this taste began in Rome, as in Florence, with the men of letter's. The comrt of Leo X., from the time of his eleration, had become the resort of the accomplished and learned men of Italy. To the names of Vida, Beroaldo, Bembo, Sadoleti, and Bernardo Accolti might be added a long list equally eminent whetlier in the ranks of poetry or philosophy. The revival of the language, and the happiest initation of the style of the Roman poets is, of itself, a sufficient eridence of the taste of the day. The elegant hexameters of Sadoleti on the Laocoon, of Castiglione on the so-called Cleopatra, and the iambics of Leo himself on a statue called Lucretia, not to mention the more copious works of Vidla and others, all tend to show how closely their admiration of ancient art was comnected with their classic associations and studies; while many a scholar partook of the antiquarian ardour of the age without being, for a time at least, at all alive to the technical merits of the works that were bronght to light.

* See Life, prefixed to the Cortegiano. 
The first symptom of a classic tendency in art is thus explained by the mere influence of this taste in the literary world; but, by degrees, the admiration of the more independent professor was attracted by the skill, the beanty, and the poetic fancy displayed in the antique sculptures. 'The mere copying of classic details in costume and architecture was, as may be supposed, the earliest evidence of the love of the antique. Filippo Lippi, Sandro Botticelli, and, above all, Mantegna, are instances in rarious degrees of this first tendency. Owing, however, to the still universal demand for sacred subjects, the opportunities of treating a composition so entirely Pagan as Mantegna's Triumphs* were not frequent.

But the engravers were not so restricted; their works were not for the chapel or the cloister ; they could minister to the elegant or corrupt taste of the rotary of classic poetry as they pleased, and the introduction of Pagan subjects may be said to date its rise from them. In 1452 the first known engraving by the inventor of the art, Maso Finignerra, appeared in Florence, and it is to be remarked that the earliest essays were not reproductions of known compositions, but original designs. These subjects soon became very generally classical. Lorenzo de' Medici suggested the Labours of Hercules to Pollajuolo, the History of Vulcan to Ghirlandajo, the Gods and Goddesses to Luca Signorelli. The contemporary examples of similar subjects in Painting are very rare, but, towards the close of the 15 th century, the private taste of the more wealthy partisans of the spirit of Paganism began to invite the labours of the painter' ; and, before 1520 , the classic influence had so spreat that the independent and rital character of Christian art may be satid to have been entirely supersected by it.

The first complete specimen of a painter who united high

* Designs for Tapestries at IIampton Court. Fuseli calls these Triumphs "a copious inventory of classic lumber." 
excellence in art with an exclusive passion for classic subjects, was Giulio Romano, the chief scholar of Raphael. He may be considered the great head of the classic school, and the more marked indications of this tendency in the subordinate works of Raphael,-the execution of which, owing to their extent, was entrusted latterly very much to his scholars, - may be attributed to the suggestion or the hand of this painter. His taste was lindled and fed by Baldassare Castiglione, and when that accomplished scholar and statesman returned in 1524 to Mantua, his native place, Giulio Romano accompanied him. The labours of the artist there, both in architecture and painting, were various, but the classic frescoes of the Palace formed an epoch in the taste of modern art. Primaticcio, who for some years was one of the numerous subordinate associates of Ginlio at Mantua, imported the style into France at the invitation of Francis I., and decorated the palace of Fontainebleau with subjects from the Odrsser. The classic taste in France dates its permanent establishment from this period, for the same painter was employed by Francis to collect antique sculptures in Italy; the result was the importation of more than a hundred specimens, together with casts from the treasures of celebrated Galleries. The arts in France may thus be said to have been nurtured in the classic school, and it is not smprising that the taste should have afterwards attained its acme in a French painter-viz.: Niccolo Ponssin. The original influence of Giulio Romano is, howerer, sufficiently acknowledged by the marked homage paid to him in the didactic poem of du Fresnor.*

* To Mason's translation of this poem, Sir Joshua Reynolds, as is well known, appended notes. The passage in question is as follows :

" Learn how, at Julio's birth, the Mruses smiled, And in their mystic caverns nursed the child, How, by the Aonian powers their smile bestowed, His pencil with poetic ferrour glow'd. 
In these cases the spirit and genius of the ancient mythology was followed for its own sake, and is directly appreciable, perhaps most appreciable, by the classic scholar and poet. But while all the artists who yielded to the taste of the day must be admitted to agree in one particular--viz. : a dereliction of the inspiring principle of Christian art-it is to be observed that the Italian painters, with the single exception of Giulio Romano, seem to have had an ulterior object in selecting these subjects. The Venetians were smitten with an admiration of colour as a main element of beauty, and justly considered the colour of the nule the worthiest object of imitation. Hence, while they cared little for classic associations, they were readily tempted by the opportunities (such as the fable of Bacehus and Ariadne painterl by 'Titian) which the characters and incidents of the mythology afforded, for giving full scope to their powers. 'The excellence of 'Titian, it must be admitted, is never' more apparent than when lie exhibits in all its splendour, the most beautiful, yet the most negative hue in nature. Again, the spell of Correggio's chiaroseuro, so nearly allied to the roluptuous, led him to select analogous subjects from classic fable; while the Florentines, and, at a later period, Amnibale Carracei, with the purer zeal of anatomical designers, eagerly seized every excuse for displaying the naked figure. The Venetians, who might have been expected to be most fascinated with this class of subjects, are certainly not to be charged so much as the other schools with having abused them. 'The designs of Giulio Romano and Amnibale Carracei, the Ios and Ledas of Correggio and

When faintly verse Apollo's charms conveyed, He op'd the shrine, and all the God displayed; I is triumpihs more than mortal pomp adorns, With more than mortal rage his battle burns; His heroes, hapyy heirs of fav'ring fame, IIore from his art than from their actions clailu." 
M. Angelo, camnot fortunately be paralleled by any Venetian work.

From the death of Giulio Romano-1546-to the rise of the Carracci-about 1580-the subjects for extensive spaces were of the same kind as those of Mantua. The Odyssey was selected by Tibaldi to decorate the walls and ceiling of the Institute of Bologna, much about the time that Primaticcio, assisted by Niccolo dell' Abate, painted subjects from the poems of Homer, together with the Acts of Alexander, at Fontaineblean. These three painters are extolled in the well-known somnet of Agostino Carracci. The subjects of the frescoes of the Palazzo Fava in Bologna (the first work that established the fame of the Carracci) are taken from the Eneid; - those of the Magnani Palace represent the listory of Romulus; - the Frnese Palace in Rome is filled with mythologic subjects that appear to have little apparent connexion.* Speaking of this work Fuseli says that Annibale Carracei, "with the Capella Sistina and the Vatican before his eyes, filled the mansion of religious austerity (?) and episcopal dignity with a chaotic series of trite fable and bacchanalian revelry." Nuch allowance is to be made for the spirit of the age; scarce half a century earlier we find the painters of what has been called the ornamental school (the Tenetian) decorating the exterior of warehouses with Scripture subjects. The Doges, in the public works of Titian, and even of Paul Veronese, are always in the presence of St. Mark, the Virgin, or the Redeemer; and Tintoret's " Paradise" adorns the Ducal Library.

The scholars and contemporaries of the Carracci, such as Guido, Guercino, and Albano, continued, with more or less natural inclination, to treat classical subjects; and the Aurora of Guido may be cited as the farourite of its class. Poussin, Domenichino, Lanfranco and others, by adding

* See the explanation in Bellori-." Le Vitc de" Pittori, Scultori ed Architetti moderni." 
T'asso and Ariosto to the classical sources, only ministered to the miversal taste for what is called profane, as opposed to sacred subjects. It will be even remembered that in such a poem as 'T'asso, the graver subjects were aroided; it was the garden of Armida, and the attractions of Clorinda and Erminia that were preferred to the pious Goffredo, and to the main incidents of the Epic.

Before the close of the 16th century the classic or profane taste had spread over Europe, with the single exception of Spain, where, either from the bigotry of the priests or the ignorance of the nobility, it never prevailed. Cean Bermudez remarks that neither Roelas, Castillo, nor Murillo ever painted an historical, much less a mythological subject. Whatever Italian and Flemish art lost, therefore, by the introduction of a classical taste, it ought not to be forgotten that the Spanish school gained nothing by rejecting it; and, had not the Sevillian painters under the auspices of Velasquez and Murillo broken through the monkish influence by treating familiar life and portrait, the school might have continued to be what it was in the hands of the artists of I'oledlo, a dry imitation of Italian altarpieces.

In reviewing the gradual introduction of mythological and poetical subjects in Italy, there is one remarkable fact which cannot but excite our wonder. The poems of Dante, so closely allied, in many respects, to the original religious aim of the Italian painters, and appearing to offer a fit transition from serious subjects to poetic fictions in general, never seem to lave been considered legitimate sources of inspiration by the Italian artists. That Orgagna, M. Angelo, and others, gave evidence in their Last Judgment of having been inspired by Dante, is well known; but the sulject itself was still the Last Judgment. The engravings by Baldini and others it is scarcely necessary to say were intended to accompany the early editions; but we look in 
vain for a series of frescoes from any one of Dante's poems in lien of the ever-recurring classics. To explain this, from the nature of some of his descriptions, is hardly possible, for, even omitting these, there are incidents in abundance which invite the invention of the artist. It is rather to be referrer to a prejudice against taking a poetical subject from modern authority, and this view is confirmed by other circumstances. While the Venetian artists, for instance, frequently painted conversations, musical parties, Sc., it does not appear that they erer thought of so poptilar a writer as Boccaccio. Again, although Ariosto's acquaintance with Titian is supposed with great reason to have influenced the descriptions of the poet, there is no evidence that Titian ever returned the compliment by treating a subject from the Orlando Furioso. As to Tasso, the Gerusalemme, when once adopted by the painters, may be said to have been the faronlite; and the predilection for incidents of this story seems to have been most strongly recommended, if not first introduced, by Niccolo Poussin. These facts, (the general truth of which would not be invalidated even if a few exceptions should be discovered) may tend to show how much the force of what is called the spirit of the age has ever had to do with the choice of subjects; for, without pretending to assign a cause, it almost appear's as if the Italian artists had no objection to modern associations and incidents provided they were real, but that they preferred deriving their poetical subjects from a classic authority. Ariosto, who modernised so many antique fables, might easily be confounded with more ancient sources. Ruggiero and Angelica embody the same subject as Perseus and Andromeda; and the escape of Orco from the Den, by Lanfranco-in the Borghese Palace, Rome-is always taken at the first glance for Polyphemus and Ulysses.

The classic taste has ever found an uncongenial atmo- 
sphere in Germany. 'There, the labours of the learned in illustrating the writings of antiquity, have been rather of the nature of research than the effect or the cause of taste; and when in the last century the resthetic and antiquarian requisites were united in Winckelmam, Lessing, Heyne, and other's, the result was perhaps more apparent in every part of Europe than in their own country. The mania which infected Italy from the close of the 15th century, seems never to have so spread beyond the Alps as to produce a lasting impression on art. The very few early instances of Flemish painters who turned their attention to pagan subjects are to be traced to an Italian influence, and not to the operation of a naturalized paganism. A single instance of a mythological subject occurs in the productions of Van Eyck, if "the Bath" which a Sovereign of Urbino commissioned him to paint may be so calledfor nothing but its name is known. By Memling no pagan subject is recorded. Lucas van Leyden also availed himself but indirectly of the privilege of the engravers, his classic subjects being very few; - a Pallas, the last engraving he did, was probably an imitation of one of the many Italian works of the kind.

Of the succeeding painters perhaps Lucas Cranach was more smitten with antique subjects than any of his contemporaries, from the opportunities they afforded of displaying his ungainly taste in the nude. Albert Durer, however, with a fondness for anatomy which might have led him to adopt subjects from the ancient poets, remained true to the Scriptures and to the legends, and preferred Adam and Eve to the Lucretias of Cranach. The painters of the latter part of the 16th century, who returned from the study of the Italian master-works, such as Bernard Van Orley, Frank Floris, De Vos, and others, imported sometimes the subjects as well as something of the manner of their models; but even when the old religious exclusiveness 
had relaxed in farom of historical and poetical subjects; when Henry Goltzins (a name synonymous with the falsest exaggeration) in affecting to shm the meagreness of his early predecessors, preferred the mythologr as a vehicle for Herculean or redundant forms; when, lastly, Rubens in his exuberant versatility allowed ancient history and poetry to have equal claims with the altar piece:-from first to last we do not find the shightest approach to the characteristics of a classic taste.

But in another species of inrention, allied to the abstract personifications of the ancients, the nations on the north of the Alps emulated to the fullest extent the practice of the Italians, riz., in the use of the Allegory. This transition from the literal to the figurative sense might indeed be traced with some appearance of plansibility from the examples of pagan art, but the nature of the human mind is of itself sufficient at all times, to accomt for its employment, and even where very little culture is supposed. It is only where the practice has reached an absurd excess, as was the case at the close of the 16 th and beginning of the 17th centuries, that it is forced on our attention; and it appear's that the influence of literature was at this period again the leading cause. A hidden purpose in mitings will be most prevalent in times when the truth camot be spoken openly. The Italian writers from the 14th century abound in concealed or ulterior meanings; - the secret opposition to the Pope, or to the Emperor-the hostility and mutual distrust of the petty Italian sovereigns, were the origin of nany a publication in which a political object has been veiled under the garb of poetry or narrative.

It may be fairly presumed that the necessity or the habit of this dissimulation in the great writers of the 14th century, and of those who succeeded them, may have been adopted by later anthors when the same motives no longer existed; a decided bias once given, the mere 
force of example as usual soon hurried it to exaggeration. It is to be remembered that it is the excess only of this tendency which is remarkable: all moral and didactic poetry has of necessity a hidclen aim, but the mode in which this may be attained may be more or less adroit. The result is perluaps never more successful than when the desired effect is produced without any suspicion of the "pious fraud." This was the first purpose of Tasso ; but the evidence of an ulterior meaning was then so indispensable that he thought it adrisable to remodel his poem with a view to a theological allegory. Ariosto's allegories are more obvious, but they are rather introduced as episodes. Without staying, however, to trace the progress of this taste in Italian poetry or its subsequent influence on northern writers, its acme may be at once instanced in our Spenser's Faery Queen, three parts of which were published in 1590 .

The first effects of this taste on the arts of imitation may be traced in the engraved illustrations of the symbols by which moral writers conveyed their lessons. The emblems of Alciatus* who lived in the time of Leo $\mathrm{X}$. were celebrated. Pierio Valeriano, who was selected by the same pontiff to superintend the edncation of his nephews, published fifty-eight books of Hieroglyphicks. Of the learned men, immediately attached to Leo's court, Paolo Giovio produced a book on devices and mottoes, and Gregorio Geraldi published an "Explanation of the enigmas of the ancients and of the Pythagorean symbols." It appears however, that the antique types were at this time little known, and even when they were, the Emblem-

* "Celebri ancora per le moltissime cdizioni e versioni e commenti sono gli Emblemi dell' Alciati, ne' quali egli, sotto figure simboliche, spiegate poi con cleganti epigrammi, descrive le virtù e i vizi-opera avuta, e non senza ragione, un gran pregio fin chè furono alla moda gli emblemi, ma ora, insieme, con essi, dimenticata."-Tiraboschi, "Litterutura Ituliuna," vol. vii., p. 1068. 
atists of the 16 th and 17 th centuries contimued to invent after their own fashion. The twelve Virtues by Raphael derived their symbolical attributes from the authorities above quoted, and have nothing in common with the system of the ancients except their number and their names. In the allegories of our own writers we recognise similar sources as distinguished from the antique Iconology. 'The Fame covered with tongnes, introduced by Shakspeare (in the Prologue to the Second Part of Hemry the Fourth), is an instance of this, and Spenser's personifications, when not his own invention, are quite distinct from the classic type. The "Iconologia" of Cesare Ripa, the great authority of painters, was published the same year' with the first portion of the Faery Queen, but a number of books of the same class had preceded it; one of these is by a painter of Vicenza, Battista Pittori; his designs are accompanied by the epigrims of Lutorico Dolce, and one of them, on the merit of Titian, may be taken as a specimen of the far.fetched allusions which were in vogue. The derice is a bear licking its cub, with the motto "Naturâ potentior ars."

Books of the same class were rapidly multiplied beyond the Alps. It will be sufficient to mention the symbols of Typotius published at Frankfort in 1602, and those of Otho Venius, the master of Rubens, in 1607. In one class of these publications the designs were merely intended to accompany and explain the poetry or moral lessons appended to them; but such authors as Cesare Ripa, Boudard, and other's, professed to furnish materials for painters. A third class invented or collected the emblems and derices illustrative of the history of particular times and persons; of these, Fabricio, on the life and actions of Gregory XIII., and Menestrier on Louis XIV., are examples. The connexion of historical devices with the armorial bearings of chivalrous times and romances is obrions. 
The allegories, even of the great painters, are not always so clear and intelligible as could be wished, but it appear's that an acquaintance with emblems was almost a branch of edncation, and many things which are now strange to us were tolerated and even admired by the wits of the time. Correggio sometimes painted professed allegories, as for instance, "The seusual man fettered by Habit and tormented by Conscience," and its pendant, "Heroic Virtue, overcoming Vice, and crowned by Glory." The subject would scarcely be giressed from the pictures themselves without the titles:- the condemnation of unsuccessful allegory lies in the mere fact that the description conveys the idlea better than the representation. In Raphael's Virtues, before alluder to, the attributes are now totally unintelligible without consulting the Iconologists. In his personifications of Philosophy, Poetry, Theology, and Justice, he has followed in a great degree and where he could, the antique types; and it is remarkable that neither Paolo Giorio nor Gregorio Geraldi were at that time to be consulted, for they came to Rome some years later. The Virtues, on the other hand, were among his last designs.

Of Michael Angelo's taste in Allegory an idea may be formed by the bas-relief belonging to the Royal Academy -the subject is Lorenzo de' Medici raising the drooping city of Florence, expelling the enemies of Order, and introducing the arts of Peace:-a short title, but far more comprehensive in addressing the imagination than the work itself, characteristic as it is in other respects. His Day and Night, Dawn and Twilight, on the tombs of the Medici at Florence, are wholly unintelligible as ideas.

But the great age of allegory was only beginning in art when it was lipe in letters; as soon, however, as it was found to be an easy passport to the approbation of the learned, many a painter of modest pretensions sought to recommend himself by the depth and wit of his allusions. 
Vasari,* Zuccaro, and their followers, aimed especially at this kind of merit. The former' gives his own description of his frescoes in the Ducal Palace at Florence, in a dialogue between a Prince of the House of Medici (Don Francesco) and himself; under the familiar abbreviations of G. \& P.Giorgio (Vasari) and Principe. He begins with the Sala degl' Elementi, and, in the midst of disquisitions in which the heathen Cosmogony and modern astrology are mixed with his own attempts at personifications, he makes the Prince occasionally exclaim, "Oh! quanto mi piace questa storia" - "certamente che questo é un intessuto molto bello e molto bene imagimato." Giorgio proceeds, "that long stone on which all the figures before mentioned rest, is supposed to be the Firmament; I could not represent it more plainly ; it is the ninth power of Heaven." In answer to some other profound information, the Prince says with great truth, "you tell me things, Giorgio, to-day that I nerer suspected were signified under these colours and forms." A female figure that flits before the Moon is explained to be her daughter "Dew." A man with a globe and an hour-glass is "Day." I'o represent Justice he disdains the ancient and intelligible sword and scales, but ar'ms her head and not her breast, decorates her helmet with white, red, and green feather's, for Faith, Charity, and Hope, gives her a shield with Medusa's head, and places in her hand a sceptre ornamented with a hippopotamus at one end and a stork at the other. His ingenuity seems most put to the test in applying the antique fables to the fortmes of the Merlici, but even here he acquits himself with ingenuity. In the historical or family allusions the dialogue often resembles the descriptions of the risions in Ariosto, where Bradamante, Ruggiero, and others, have the fortumes of the house of Este revealed to them. The letters of Vasari enlighten us still further, for we find that even in portraits the

* The edition of Vasari referred to is that of Florence, 1882-8. 2 vols. 
costume and accessories may all be male to allude to the history or' excellent qualities of the individual. 'T'he round stool on which Alessandro de' Medici sits indieates that his power is to have no end; the legs of the stool, the colom of the drapery, the polish of the armour, all have their meaning; and all would certainly be little suspected of having any, with the exception of a helmet on fire on the ground, the unusual appearance of which might excite curiosity. It means eternal peace.

The folly of the painters was encouraged by the same absurd taste among their employer's. Tasari, in another of his letters, speaking of a figure of Marpocrates on which he was employed, says, "I have made him with very great eyes and ear's, wishing it to be inferred that he saw and heard much, Se.; he has a crown of cherries and medlars on his head, the earliest and latest fr'uits, to represent judgment, which, mingled with sour (destiny ?), becomes matured by time; he is girded with serpents, and places one hand on a goose, to indicate vigilance; all this Pope Clement made me do as a type of our Cardinal (Ippolito de' Medici)."

The inventions of Federigo Zuccaro, to judge from his didactic mitings, must have been equally profound, but as he has left us but few descriptions of his works, his allusions cannot be so easily traced. An allegorical satire which he painted in Rome and exhibited publicly, compelled him to quit that city for' some years. * 'The Italian schools, which had sumk into mannelism and affectation in the hands of pedants such as these, again revived, as it were by a common effort, towards the close of the 16th century. Many cooperated in this, but the Carracei have the chief credit of the change. Their efforts were chiefly directed towards the improvement of the art itself, and hence Allegory was with them a secondary object. 'The fashion of the age, howerer, still proved to be irresistible, and every artist, sooner or

* Ile was in England after this at the court of Elizabeth. 
later, acknowledged its influence. In Bologna the works of these painter's embodied either classic stories or religious subjects, but when Amnibale Carracci, assisted by his brother Agostino, midertook to paint the Farnese Palace in Rome, he selected various mythological subjects with a view to a hidden allegory. Bellori, who explains the Farnese frescoes, does not even hint that any allegory was intended in the Fava and Magnani palaces at Bologna, whence it may be inferred that Rome was still the head quarter's of this taste. The explanations of Bellori do not come with the authority of Vasari, for that painter, describing his own works, leaves us in no donbt whatever as to his intentions. The following passage from Bellori's account of the Judgment of Hercules-painted by Annibale Carracci in a room adjoining the great Farnese Gallery-if correct, gives but an indifferent impression of the good taste of the painter. "The red mantle of Virtue with the purple tunic are emblems of Divine Valour; and the yellow drapery with which Pleasure is adorned, reminds us that her gratifications soon wither and fade to straw colour."

Among the circumstances which contributed to stimulate and keep alive the love of Allegory and emblematical representation, may be reckoned the Trimmphs, Pageants, Masks, and Toumaments, so frequent in the 16th and 17th centuries. The mechanical powers of Leonardo da Vinci had produced wonders at a Pageant in lonour of Francis I.; but, in later times, when Painters had learned to unite rapidity of execution with effect, the best talents were often in requisition to decorate the temporary arches and façades with inventions befitting the occasion. A great many of these works have been handed down to us by engravings, but they are oftener merely described; they, one and all, exhibit the usual elaborate conceits, with the full complement of "Thrones, Dominations, Princedoms, Virtues, Powers." Vasari in a 
Ietter to Aretino gives a minute accomt of the paintings and decorations in Florence in honom of the arrival of Charles $V$. The description of a similar festival in Bologna, on the occasion of the visit of clement VIII., 1598, is accompanied by the etrhings of Guido. The same painter designed and etched the devices employed at the finneral olsequies of Agostino Carracci, in 1603. At the ceremony of the translation of the remains of Paul V. from St. Peter's to S. Maria Maggiore, Lanfranco inventerl the Allegories. Andrea Sacchi's designs on the occasion of a trimmplat entry of sone Prince into Rome also exist; but none of these records are more interesting than the description of the decorations of Antwerp on the arrival of Prince Ferdinand of Austria as Governor of the Netherlands it contains 45 designs by Rubens, engraved by Van 'Tulden. The cities of the Netherlands were famous for these pageants, and this is to be partly accomted for from the numbers of painters in distemper who resirled in Flander's to design subordinate works for the Tapestry mannfacturers. At Antwerp, on a similar occasion no less than 233 painters were employed.

The head quarters of tommaments and masks was Ferrara, but Mantua, Milan, and other cities encouraged the same amusements.* It was probably at Ferrara tha the first Italian Comedy was represented. The Pageants there in the Carnival of 1561, which celebrated the nuptials of the Duke Alfonso with an Austrian Princess, must almost have realized the romances then so much in farour. These Toumaments were generally part of a romantic allegory, as may be gathered from the titles of some of the descriptions that have come down to us. "Love prisoner" in Delos, a 'Toumament in Bologna." "The Tournament in Mantua, and the invention and allegory with which Signor

* The mask of "Adam," at Milan, is supposerl to have suggerted materials to Milton. 
Borso Bonacossi supported it." The classic taste of Florence too appears in a "Mask of the Genealogy of the Gods of the Gentiles," which last took place there in 1565. Again, a painter so smitten with the picturesque as Paul Veronese, was not slow to avail himself of the materials which Allegory offered. His works accordingly abound with emblematical figures, and his more decorative compositions must have had a close relation with the pageants above alluded to. Thus, while in sacred subjects the painters were at liberty to people the carth and air with angelic assistants, Allegory equally enlarged the machinery of the picturesque in profane subjects; so that earth and air might always be peopled with the forms and hues that best served the ends of effect.

These exhibitions, at least those of a chivalrons kind, were equally frequent in Germany and France. When, therefore, we consider that Rubens was, in the first place, early initiated in the science of Allegory by his master Otho Venius, and by the example of the painters of the day-that his intercourse with courts lad familiarised him with such spectacles, to which also, it appears, he sometimes contributed-and lastly, that the minds of all, but especially of the higher classes, were fully lisposed to enter into these conceits, we shall look on the frequent introduction of allegorical personages in his works as a natural consequence of the spirit of the age. And although we recognise in Pubens a fondness for these personifications, it must be admitted that Allegory was chiefly used by him as an important auxiliary, and that wherever he did resort to it the picture gained by it. It should be remembered too that in Rubens' time the antique types were better understood, and the enigmas of the modern Iconologists were beginning to give way to them. The abstract personifications of Poussin were of course culled from the antique, or invented in its spirit. His vision of Rome and Fortume in 
the picture of Coriolanus may be tracerl to classic sources; but the personification of the Nile, with heat hidden in the reeds, alluding to the undiscorered source, probably originated with him-raleat quantum. 'The idea has been often copied since, and has found more favour than it deserved. The symbolical language of the ancients as applied to art is not only the clearest, but has the recommendation of being more current than any other.**

The evils which the abuse of this taste entailed on Painting were still further aggrarated in seulpture. The figures of Falsehood, Heresy, Infidelity, which are so frequent in Italian monmments, were made as hideous and monstrous as possible, on a principle directly opposed to the nature and powers of the art; but the allegorical mania went still further. To represent Death without its terrors the sculptor of a Papal monument surmounted the whole with a gilded skcleton. In the Tilla Mattei a marble Trutl opens with both hands a gash in her breast, as if to bare her heart to the beholder.

There was one rery general and very decided taste in literature which had no influence on Art in Italy, and but little, if any, in Germany; this was the passion for tales of chivalry. Subjects from Boiardo and Ariosto were, as we lave seen, not often treated by Italian painter's, and, when they were, it was without the slightest approach to what is now understood and felt by the term "romantie." To account for this it should be remembered that, besides the permanent objection to such subjects (from their substituting uncouth forms for the nurle) the real age of armour was not past, and the knightly costume with all the "pomp, pride, and circumstance" of chivaly was perhaps too everyday an oceurence to produce the effect on the imagination then, which it produces now; while the enchuntments so indis-

* It has been collected and exhibited in a series of engravings by Millin-a better manual than Cesare Rija. 
pensable in the machinery of these stories were beyond the powers of representation. The trimmphs of Christian Warrior's over their Paynim enemies, so prominent a source of interest in these books, and, as it would appear, so legitimate a subject for Catholic peneils, seem nerer to have attracted artists. The few subjects of the kind that exist were purely historical, such as the defeat of the Saracens at Ostia, by Raphael, the expulsion of the Moors from Spain, by Velasquez, a few allusions to Eastern victories in Tenetian altar-pieces, and the Battle of Lepanto on the ceiling of the Gallery in the Colonna palace at Rome by more modern hands. Before our own time no Spanish 1)ainter seems to have adopted a single subject from Don Quixotes Library; no Italian or Frenchman cared to represent the deeds of the Paladins in Boiardo and Ariosto; and no German ever thought of the Niebelingen Lied. The "Knight" of Alber't Durer was perhaps intended as a characteristic figure; at all events it corresponds in many respects with the chiralrous "ideal." Giorgione seems to have been somewhat smitten with this taste, as may be inferred from his selecting a fashion of armour a little older than his own time. But the portraits and events of the period, though with all the advantages of knightly costume, were far too leal for the chivalry of the poets. The most remarkable work of this clins was probably Titim's Battle of Cadore, in which the Imperial knights were represented charging across a narrow bridge in an tlpine scene and iluring a storn. The picture was destroyed by fixe, but a sketch of a portion of it is in the Gallery at Florence, and there exists an old engraring of the entire composition."

Of the Saints who appenred in ams, st. George, St. Hubert, St. Martin, St. William, and one or two other's of

* (See subseruent information on this subject. with plate of original design, in Gilbert's Cadore, p. 1sti.) 
less note-the first was most frequently painterl, but perhaps never in a spirit analogous to the chivalrous legends. The Church of S. Giorgio dei Schiavoni at Tenice was once decorated with a series of subjects from the life of the Saint, but it was Carpaceio who was the painter, not 'Titian or Giorgione. Tintoret might be supposed to be fully alive to the romantic requisites, yet his picture of St. George and the Dragon in the National Gallery, whaterer merit it may have, does not possess, to modem eyes, a chivalrous character, or the impression of a chivalrous period. Paul Veronese, or his employers, preferred the martyrdom of the Saint to his heroic deeds, and Rubens, who has represented St. George more than once, had an object in view quite distinct from the poetry of Romance. The St. Hubert of Albert Durer, though not an armed linight, is sufficiently romantic, and, on the whole, the chivalrous taste seems to have lad more roturies in Germany than elsewhere. We find eren a fond. ness there for the representation of armour in sculpture-a taste by no means to be defended. 'The tomb of Maximilian at Innspruck suroumded by 28 bronze statues, is a curious instance. After all it may be affirmed that the chivalrous mania in literature was never really communicated to the arts of design, and not a single painter can be instanced who has acquired a name for adequately embodying the characteristics of that species of poetry. The objections arising from the nature of the art have been alrearly alluded to, but the picturesque and the romantic own no such restraints. Although, therefore, it may be little desirable to revive such subjects now, yet when we reflect on the variety of ignoble materials which the attractions of art, and the power's of genius hare recommended, it cammot but be matter of surprise that the once extravagant fondness for these fables should never have been ministered to by the pencil.

'The pastoral taste found more farour with the Venetians, 
probably because it offered a fair excuse for the introduction of the naked figure-the allowable accompaniment of a golden age-but such subjects, as treated by them, horrerer ostensibly ideal or remote, are not to be confomded with antique Idylls and Eclognes. It is even possible that they may have been altogether the result of the picturesque and music-loving manners of the time and place, as the sheplierdised creations of the French in the 17th century grew ont of the theatre and the comrty masks and greenwood fites. Tet there was a fondness in Venice for one pastoral writer, quite unequalled in any city of Italy. Nearly thirty editions of the Arcadia of Samazarius appeared in Venice in the 16 th century. The first two, pinted in 1501-150t, were so imperfect that the author wrote a letter of complaint to a friend in Tenice on the subject; a third appeared before the first improred edition by Aldus in 1514. The Arcalia may therefore be said to have been in erery hand before Giorgione died. And it is impossible not to attribute to this elegant work some degree of influence on a style of art, and a selection of subjects totally distinct from the classic Bacchanals of Giulio Romano, and strictly confined to Venice, until imitation spread it elsewhere. The consideration of the concurring influence of manners will be resumed in another place.

The plilosophical speculations of the Italians of the 15th and 16th centuries may be considered as the most important consequence of their classic studies: the thirst for the writings of the ancients was marlied indeed by no particulin predilections-poets, orators, historians, and philosopher's were read with equal aridity; but philosophy was the subject that of itself required the greatest attention, and involved the rreatest discussion. 'The deptlo of the abstruser doctrines of Plato and Aristotle by degrees engaged the serious meditation and ultimately excited the wonder and reverence of the best intellects in 
Italy. It is not meommon for modern historians to date the reviral of letter's from the attentive study of Plato at Florence. It was there the most learned Greeks had taken refuge, pleased to repay the hospitality they received by elncidating the difficulties and extolling the matchless structure of their language. And it was then that the garden of the Medici might be said in more than one respect to lival the Athenian academy.

But notwithstanding the authority of the Father's of the Church, who attest the sublimity, and ahmost the orthodoxy of Plato's doctrines, the pagan tendency of the study of his philosophy, mixed up, as it was, with classic researches of all kinds, was but too apparent; and Florence was the first city in Italy to assume a character entirely opposed to that spirit of the midulle ages, which, after all, had made her what she was. The alam of the Church har already been exciter, but it was lulled to security, at least for a time, as soon as Leo X. ascended the Papal throne;--the classic Leo, who had been nurtured in the Platonist schools of his native city, and trained to emulate alike the taste and the philosophy of the ancients.* With him and the learned and accomplished men who repaired to his court, the head quarter's of Platonism may be said to have migrated to Rome. The classic mania had not, howerer, been suffered to prevail thus far without violent opposition, and while the attacks of such enthusiasts as Saronarola lasted, the partisans of the ancients seem to have hushed their private differences of opinion, to make head against their adrersaries. But no sooner was the classic taste in a fair way of acquiring the empire which it has ever since maintained, than the relative claims of the ancient writers among themselves began to be warmly discussed. A war, which had

* Yet, in a few years, he was eompelled to suggest or acquiesce in a decree of the Council of Lateran (1517) restricting the study of the heathen philoserilhy. 
long been smouldering, now declared itself between the follower's of Plato and Aristotle; *and, perhaps by way of gaining firiends among the anti-pagan party, it was afirmed by the admirers of Aristotle that his principles were eren more reconcileable with the Christian dogmas than those of his rival. From whatever cause, Plato, in the end, lost ground, while the study of Aristotle acquired a decided preponderance. The preference for Aristotle did not, however, become general till near the midlle of the 16 th century; but, before the accession of Leo X. in 1513, which naturally caused a reaction in favour of Platonism, the credit of the Stagyrite was so far established that the less elevated or less dangerous mature of his speculations (the very circumstance that made him more popular in the end) was the only point on which he was considered inferior.

The evidence which works of art afford of the effect of such speculations and controversies camnot be supposed to be rery apparent or very numerous, yet, as they occur chiefly in the works of Raphael it may not be minteresting to trace them.

The room in the Tatican where Raphael began to paint, called the Camera della Segnatura, is adomed with four subjects, one on each of the four walls, viz.:-Theology, Philosophy, Ethics, and Poetry. The subject of Ethics consists only of three figures, viz.: Prudence, Fortitude, and Temperance. On the ceiling are four single figures, personifications conresponding with the respective subjects, viz. : Theolugy, Philosophy, Justice, and Poetry. The title of Jurisprudence has been generally given to the subject of Ethics, owing to a mistaken appreheusion of the meaning of the presiding Justice.

Some of the commentators on the Ethics of Aristotle

* This war had commenced so early as the middle of the 15th century, out the prudence of Cardinal Bessarion, himself a Greek, had then reconciled the adver'se parties. 
have deduced trelve rirtues from his system; but, it must not be supposed that the philosopher who ridiculed the Pythagoreans for attaching importance to mumber's had any fancy on this subject. It is not quite clear that he distinguished twelre, and it is certain that different commentator's have composed their list differently, for all which dogmatism Aristotle himself is made to answer. If we consult the fountain head we find that this philosopher in his general division of Virtues considers some as intellectunl energies, and other's as presirling over the affections and passions, while Justice alone resides in the will. It may be gathered fiom his statement that Prudence is at the head of the intellectual virtues; that Temperance presides orer the desires; and that Fortitude nay represent the defensive passions. Justice, Aristotle distinctly says, is the Virtue that gives efficacy to all the rest and is mixed uy with each. The treatment of this subject by Raphael is clearly taken from this beautiful classification, which, it may be observer, the moderns have never improved on. Instead of four cardinal rirtues he gires us three only: Prudence, Fortitude, and Temperance-these represent the whole twelre, but Justice presides over all, and is placed in the portion of the ceiling colresponding with these three figures.

It would be diflicult to find who fin'st made the list of the twelve virtues, but the number is now conse. crated, and the personages themselves have been painted again and again by Italian artists. Raphael has introduced them all in the Loggie, with the three Theological or Christian rirtues of Faith, Hope, and Charity. Alexander Piccolomini, an Italian philosophie witer of the 16 th century, enumerated the twelve with laudable distinctness; * and though it may be doubted whether Aristotle would latify the enumeration, it is certain that it agrees with the

* Prudence, Magnificence, Fortitude, Meekness, Magnanimity, Temperance, Jiberality, Love of Honour, $\Lambda$ ffahility, Truth. Friendship. Justice 
personifications of Raphael. In the "Discourse of Civil Life," by Bryskett, a friend of Spenser, we find the following passage: "herein do I greatly envy the happiness of the Italians, who have in their mother tongue late writer's that have with a singular easy method taught all which Plato or Aristotle have confusedly or obscurely witten, of which some I have begun to read with no small delight, as Alexander Piccolomini, Gio. Battista Giraldi, and Guazzo." There can be no doubt that Spenser was acquainted with these writers, perhaps had recommended them to Bryskett, and it may be presumed that he had studied Aristotle himself, yet his deviation from the system of the philosopher, while he pretended to follow him, is one among the many proofs of the distortions which these doctrines underwent. In his letter to Sir Walter Raleigh, Spenser says he intended to wite twelve books, each exemplifying one of the twelve vintues of Aristotle, and that Prince Arthur personifies Magnificence, which, Aristotle say's, is the presiding virtue without which none of the rest are perfect. We have seen that the Philosopher says this not of Magnificence but of Justice. Again, the first book is Holiness; which of the Aristotelian virtues is this?

It may be observed, with reference to what has been before said on the subject of Allegory and symbolical figures, that Raphael has had the good sense to give his Justice the sword and scales; attributes so universally known that this personage is one of the least objectionable in the Iconology : her head is crowned with a regal diadem, such as is seen on the heads of Juno, thus confirming the notion that she is the paramount Virtue.

In the subject of Philosophy, or, as it is commonly called, "The School of Athens," Plato and Aristotle appear with equal honours, surrounded by their disciples. 'The figures and actions of the two philosophers express with justest discrimination the nature of their respective studies and doctrines. 
Aristotle stretches his arm and wide spread hand before him as if he would grasp the surface of the rorld; the book he holds in the other hand is inscribed with the title, "the Ethies.' Plato points to Heaven, holding the dialogue entitled Timrus under his left arm. The researches of Aristotle in natural history are among the most prominent of his labours; the then limited knowledge of nature, the ignorance of the microscope, and the imperfect notions of the hearenly bodies, all opposed formidable obstacles to his investigations; ret, notwithstanding the unaroidable error's he fell into, we may safely respect the testimony of Buffon, who says of him, "Aristotle, who is as great a philosopher as Plato, and a better physician, instead of wandering in the regions of theory, collects facts and speals in a language more intelligible." * With the portraitures of these philosophers by Raphael any just description of their views and aims would correspond. And accoldingly we find an unintentional illustration of the great artist's conception in the following passage from Groethe. After a masterly sketch of Plato and his doctrines, he adds: "Plato stands in relation to the world as a blessed spirit who is pleased for a time to dwell in it. It is not so much his purpose to seek to know the world as to communicate to it what he brings, and what it wants. He penetrates into depths, rather to inform them with his presence than to search into them. He seeks the elevated regions of thought, as if yearning to repossess his own. Everything he utters relates to an Eternal All, Good, True, Beautiful; the furtherance of which he strives to excite in erery bosom. The details of earthly knowledge which he acquires are condensed, it may be eren said eraporate in his method, in his communication. Aristotle, on the other hand, stands in relation to the world as a hmman being, a builder. Once for all he is here, and must work and act. 
The earth is a foundation for him, but its surface suffices; from thence to the centre the rest is indifferent. He draws a rast area for the ground plan of his building, gathers materials from every side, arranges them, and rises upward by regular steps like a Prramid, while Plato seeks the hearens like an obelisk, like a pointerl flame."

The engraver 'Tomasino, who retonched the first print of the School of Athens by Giorgio Mantovano, added diadems and the nimbus or glory to the heads of Plato and Aristotle.

'The revived or increaser admiration of Plato during the pontificate of Leo $\mathrm{X}$. is not withont its evidence in the works of Raphael. Beroaldo, the Librarian of the Vatican, had published with a copious commentary the "Golden Ass" or" "Metamorphoses" of Apuleins, a distinguished Platonist, whose character' as a philosopher should not be judged by the light production in question. Yet, as if everything from so learned a source must necessarily have reference to recondite doctrines, Beroaldo does not liesitate to say that muder a mystic reil the abstruser philosophy of Plato, and even of Pythagoras, might be discerned. This opinion relates to the whole work in which the story of Amor and Psyche is only an episode. The allegory of that story had been explained by Fulgentius,* and its hidden doctrine is perhaps derived from Plato's two dialogues, called Phrdrus and Symposion. The subject of Amor and Psyche seems to have been confined to Raphael and Baldassare Pernzzi, but a similar allegory was often treated afterwards. It is the moral, according to Bellori, of Amnibale Caracci's great work (already mentioned), and was suggested, in his case, perhaps by the proximity of the Farnese palace to the villa called the Farnesina, where Raphael painted the subject from Apuleins. Titian, and other painter's, who treated the same lind of general allegory, probably all drew from the same source.

* Enarrationis allegorica fabularum, Fulgentii Placiadis. 
A more direct consequence of the influence of literature in matter's of taste is to be sought in the effect of the various books on art which have succeeded each other from the 14th century to the present time. The credit of Tasari's work, "The Lives of the Painter's," has had the effect of giving currency to many opinions and statements which are not always reconcileable even with historical truth. In many particulars, indeed, his er'ror's and misstatements have been pointed out, since they were easily detected; as, for instance, where he ventures to describe the fiescoes of Raphael from the prints of Mantorano and Marc Antonio. 'These, having been either' engrared from designs, or' intentionally altered, differ in many respects from the frescoes themselves, so that Vasari's account of them is often quite inapplicable. In such matter's his assertions naturally have not become law; but in others, hereafter to be noticed, where it was difficult to obtain other sources of information, he was long unanswered; thus even his partialities acquired a consecrated anthority. Biography is always attractive; and, notwithstanding the more obrious blumder's, such as that instanced above, with which Vasari's narratives abound, the entertaining chararter of his work, the purity of his Tuscan idiom, and the value of a professional testimony in all practical matters, and where he describes what he had seen, have contributed to place this work at the head of its class. With respect to its general influence there can be no doubt that the Florentine artists and even MI. Angelo himself have lost nothing in the estimation of posterity by the eulogies of their countryman. His depreciation of other schools and individuals, where he camnot but extol, or where he camnot altogether suppress the merit of the artist, is to be detected in invidious allusions to personal history. In most of these statements he has been successfully contradicter, as in the account of Raphael's and Francia's death, of Perugino's irreligion, fre. The 
immediate neighbours of Florence are, as might be expected, the most unfairly treated; the early claims of Siena are passed over, and the Bolognese painters who succeeded Francia are treated with undissembled ridicule. Perhaps to this attack the valuable history of the Bolognese school by Malvasia may owe its origin. Vasari finds fault with Raphael's drawing of the mude, and elsewhere observes that he who does not study the figure early (as the Florentines did) can hardly ever become perfect. He asserts that Raphael attempted in rain to rival the style of Leonardo da Vinci, but that he did profit by imitating that of M. Angelo.* He conchdes his critical observations by regretting that the Transfiguration had turned black. The Tenetian painters, with the greatest of whom, 'litian, Vasari was personally acquainted, are criticised for not preparing cartoons as the Florentines did ; $\dagger$ and Titian himself, when he risited Rome, is allowed the palm of superior merit only in portraits. Of Correggio, whose merits are acknowledged with great brevity indeed, but in terms of high praise, he says that if he had quitted Lombardy and risited Rome he would have done wonder's. In the same Life he observes that nature " not to be thought partial, had given some rare geniuses to other" states, like those who for many years had adorned Tuscany." It is, in short, for Florence, and above all for M. Angelo,

* The question whether Raphael altered his style from a secret inspection of the Capella Sistina, as has been too often repeated from Vasari's statement, is well examined in Quatremère de Quincy's Life of Raphael. Sir Joshua Reynolds improves even on Vasari, when he says, "It is to M. Angelo we owe even the existence of Raphael,"

+ The three foreshortened pictures of Abraham and Isaac, David and Goliah, and Cain and Abel, were executed by Titian, because, says Vasari, he himself could not stay in Venice to complete them. The real cause is, however, hinted at, that Titian understood the art of foreshortening on ceilings. The pictures in the Salute are not originals. Speaking of a picture of the Presentation by Schiavone, Vasari says: "La quale è fatta con una certa pratica, che s'usa a Vinezia, di macchie ovvero bozze senza esser finita punto."- Vita di Batt. Franco, p. 909. 
that his chief adoration is reserved, and his account of that great artist far exceeds, eren in extent, any of the other Iives. The short account of the Flemish painters which Tasari gives at the close of his biographies is sufficiently indulgent, but he derives his information, as he tells us, from two Flemish artists in Florence. When he can judge for himself, as in the case of Michael Coxis, Calcar, and others, he praises them for approaching the Italian manner. Thus foreigners are estimated by an Italian standard, and the Italiams by that of Florence.

The popularity of this work cast all others into the shade; for it happened that no enlogist of any other school was so fortunate in recommending himself as an author. The history and defence of the Bolognese (as already said) were undertaken by Malvasia. The names of the Carracei and their contemporaries, whose fame Vasari did not live to witness, added weight to this performance, but it is very far from being so amusing or so critically judicious as Vasari. Bellori, who wrote the lives of Annibale and Agostino Carracci, and those of some of their followers, describes the works of Raphael and exalts his fame without any allusion to those of M. Angelo. His description of the frescoes of the Vatican has been the accredited hand-book on the subject ever since, and it may be observed that no such account of the Capella Sistina ever appeared. The excellence of Correggio, as we have seen, was not disputed, though but briefly noticed by Vasari; had he been less honourably treated we might have had authentic accounts of him and his works by some indignant partisan earlier; for except an imperfect account by Mengs, there has been no life of Correggio which could be depender on till that by Pungeleoni appeared. The merits and full reputation of Correggio were brought to light and established by some painters at the close of the 16th century. 


\section{Boschini was the eloquent defender of the Venetian} school, but, as he wrote his principal work, a poem, in the Venetian Dialect, it is but little known.* He places Titian

* "La Carta del Narigar Pittoresco, Dialogo tra un Senator Venetian deletante, e un professor de Pitura soto nome d'Ecelenza e de Compare, Comparti in oto venti. Con i quali la Nave Venetiana vien conduta in l'alto mar de la Pitura, come assoluta dominante de quelo a confusion de chi non intende el bossolo de la calamità. Opera di Marco Boschiui, Academico Delfico, \&c. In Venetia, 1660."

Some idea of the quaintness and humour of this work may be formed from the following quotation from the preface, here literally translated :-

"There is no doubt that he who wishes to build a ship must go to the forest for wood. But it is equally true that it is not enough to have dry and seasoned timber cut under a good moon, for, if it be not put to use by a skilful carpenter, there is risk of making, as the saying goes, out of a lance a thorn.

"To tell the truth, when the thought came to me of building this my ship of painting (nave pitoresca), knowing myself to be a barren forest, although with a little unhewn timber, I found that my brains were 'tabnla rasa.' I therefore had recourse for aid to the Venetian artificer Proto, the arch proto, Intendente, the arch intendente, indeed the Plenipotentiary of Painting, who has courteously helped me by giving me a number of master workmen, with all the materials ready at hand which are needful to my undertaking. And, moreover, he has also provided me with suitable building stocks, that is, Venice, on which Gian Bellini, with all care, has laid the first framework, having for assistants his brother Gentile and Vitor Carpaccio. Tintoretto has given the design, so that the ship may have a form that will enable her to stand any sea. Giorgione has put on the rudder that she may be put to port and starboard as may be necessary. Pordenone has set himself to work to frame the timbers according to measurement, shortening and lengthening them for the better shape. Bassano has made the portholes to give light to the cabins and captain's chamber. Zelotti has fixed the mainmast straight and sound. Salviati the foresail. Paris Bordone has gilt the poop. Paul Veronese has adorned it with a lantern all bejewelled. Schiavone, a great calker, has calked her seams. Palma Vechio has sewn her sails that she may sail the faster. And, moreover, many other Pupils of the painters have done the more common work, such as placing the timbers on the ribs, joining them, tarring them, and everything else required to complete her. The most skilful Titian, true Admiral of Painting, assisting at all these operations."

Boschini's other work, "Ie ricche Minere della Pittura Veneziana. Venezia, 1674," is written in correct Italian. It gives short lives of the principal painters, and then conducts the reader to every picture then in Venice and in the surrounding islands. It is in the same style of enthusiastic laudation, and apostrophises Venetian art as the "twin of Naturc." 
at the head of all painters, and replies with becoming warmith to the attacks of Vasari on that painter, on Palma, Schiarone, and on the general practice of the school. He relates that when Liberi was in Rome studying the Last Judgment of M. Angelo, Giuseppe d'Arpino asked how he conld waste his time there, when he had Tintoret and Titian to look at at home. He adds that Velasquez, when at Rome, being asked by Salvator Rosa his opinion of Raphael, answered that he thonght Venice the best school and Titian the greatest painter-that Rubens and Vandyck always maintained the same opinion-that Albano and Pietro di Cortona considered Tintoret second to none; and that Guido placed Paul Veronese at the summit of the art. These and many other authorities, whose opinions of particular works are giren, Boschini quotes chiefly from his own experience; and the greater part of the anecdotes he relates, all redounding to the honom of the Venetian painter's, are interesting from the details and even from the familiar style with which they are giren.**

Scannelli, in the "Microcosmo della Pittura" + - published 1657-makes Rapliael, 'Titian, and Correggio the great Triumrirate. He was perhaps the earliest writer who embodied the opinion, adopted since the time of the Carracei, that Correggio was in the first rank of ex-

* Speaking of Gian Bellini ("Zambelin ") and his great merits, Boschini has the following stanza :-

" Chi no vuol creder che sia cusi, Togia la pala di San Zacaria E à Roma in spala se la porta via. Che i vederì, che l' è co digo mi."

Which may be thus translated :-

$$
\text { - Tento Primo, p. } 31 .
$$

"He who will not beliere that this is so,

Let him take the altar-piece of San Zacearia, And carry it off on his shoulders to Rome, He will then see that it is as I say."

† Libro 2, pp. 283, 281, \&c. 
cellence. He asserts the superiority of Raphael to M. Angelo and Leonardo da Vinci, and says that Vasari had no foundation for stating that he was the scholar of the two great Florentines "and did not reach their perfection."

An earlier writer, Lomazzo, in his "Tempio della Pittura"-1590-althongh he does not profess to combat Vasari, yet differs essentially from him, and may be understood to give the highest honors to Titian.

The "Dialogo sulla Pittura" by Ludovico Dolce, the friend of Titian, can hardly be considered polemical. In the "Discorso sul Merito di Tiziano," the Veuetian painter is naturally placed at the head of the art.

It is scarcely necessary to say that many works are passed orer which are merely didactic.

About the middle of the 17 th century, tro individuals, the one a Neapolitan painter, the other a French amatem, rentured openly to attack the picture of the Last Judgment by M. Angelo. It does not appear that Salvator Rosa was stimulated to the serere criticism contained in his third satire by any disgust at Vasari's partiality for his own countryman; yet it is not impossible. For he might have had some reason to think the painters of his part of Italy neglected by an historian who professed to be universal. Roland Fréart de Chantelon was the friend of Poussin, and of Errard, the first Director of the French Acarlemy in Rome;-his contemptuous censure of Vasari for blundering in the description of the frescoes of the Vatican is scarcely warranted by its cause, and his strictures on M. Angelo are only equalled in times nearer our own by those of d'Azara and Milizia. The French may have had some ground for pique against Vasari, for there seems no reason why, in the chapter which he derotes to ultramontane artists, in which he gives a place to painters on glass, he should not have included some of the French who 
were really fumous in this department: nor was it likely that the name of Jean Cousin should have been ntterly unknown in Italy. But, from whatever cause, we find the French comnoisseurs, from first to last,-De Piles, Felibien and Falconet,-little disposed to acquiesce in the decisions of Vasari; the painters who appeared before and during the age of Louis XIV. claimed a share of the same pre-eminence which France had attained among the nations of Europe, but the full expression of this independence was reserved to a later period. The Marquis l'Argens, in his "Reflexions Critiques sur' les differentes écoles de la Peinture" (1751) asserts the superiority of the French to the Italian School, and compares the best Italian names with equivalent or surpassing talents selected from among his own countrymen. Jean Cousin is the parallel to Leonardo da Vinci; Le Brun is confronted with Michael Angelo;-Titian with Blanchard;-Tintoret with Van Loo;-Raphael with Le Sueur;-Correggio with Mignard; Sc., Sc.

The Germans seem to have been content with Vasari's admission that if A. Durer had been born in Italy he would have equalled the best painters of his time. 'The engravings of the great artist of Nuremberg excited, as well they might, the unfeigned astonishment of the Florentine, and the friendly intercourse which subsisted between the artists of Germany and Italy naturally disposed Vasari to do all the justice he could where a total difference of taste and interest obviated all invidious comparisons. In the imitation of the Italian masters, which for some time characterised the German painters, an exaggeration of the mamer of $\mathrm{M}$. Angelo is very conspicuous, and if Pellegrino Tibaldi-a native of Modena-merited from the Bolognese the appellation of the reformed Mr. Angelo, Spranger and Hemry Goltzius might be called his caricatures.

In our own country, where there could be no reluctance, 
from the grounds of dissatisfaction before alluded to, to adopt the opinions of Vasari, and every reason, during the last century, for taking the opposite side to the French, the homage to Michael Angelo was a characteristic tenet of the School. In Sir Joshua Reynolds this admiration assuredly was quite independent of authority, but that he followed the statements of Vasari implicitly, even when they are not borne out by facts, is evident from his asserting that "it is to Michael Angelo we owe even the existence of Raphael." The unfriendly feeling which existed between Mengs and Reynolds may also have had its influence. Mengs, like Scannelli, excludes M. Angelo from the highest honors, which are decreed to Raphael, Correggio, and Titian; and d'Azara, the friend of Mengs, expressed a far less reserved opinion to the same effect. It was thus quite natural that Reynolds should distinctly and emphatically declare his admiration (the sincerity of which there seems no good reason to doubt) for so great a genius at a time when so many were disposed to mulerrate him.

His acquiescence in Vasari's opinions is again apparent in an instance where they were less worthy to be followed. The study of the Venetian masterworks had contributed to produce in one so gifted himself by nature, a knowledge, a taste, and a dexterity in colour which often placed him on a level with the great painters in question. Yet, of all the detractors of the Venetian School, (and there never were many) none can be said to approach the sweeping severity of Reynolds. The canse of this is partly explained by himself, for it appears that he thought it his duty, while the character of the English School was scarcely formed, to deter those whom he addressed from aiming at the perfections of colour, lest they should neglect the severer study of form. While respecting such a motive, it must ever be regretted that so excellent a critic should underrate some of the greatest masters of art the 
world has seen: it is abore all of importance to observe that such extreme opinions were new in Europe. That they should have been thoughtlessly adopted since by many in our own country from such an authority is not to be wondered at, and it were to be wished that every portion of the excellent discourses of Reynolds were as well remembered as this ungrateful attack upon the Venetians.

It was not suffered to pass in silence: an answer appeared in Venice in 1783,* in which the English President is accused not only of misrepresenting the qualities of the Venetian painters he alludes to, but of suppressing the names of the earlier masters - such as Bellini, Carpaccio, and Cima da Conegliano,- who, from the religious gravity and sererity of their style, are altogether exempt from the dangers of that accomplished facility which afterwards prevailed. The adoption by Reynolds of Vasari's contemptuous expressions regarding some of the Tenetian artists, particularly in the case of so great a painter as Tintoret, is treated as illiberal and uncandid, and the opinion that the Bolognese colour is superior to the Tenetian is laughed to scorn. The testimony of various writers and painters ${ }^{\dagger}$ are accumulated to prove the miversally high estimation of Venetian art, and the avidity with which its specimens were sought after by the English (he might have added by Reynolds limself) is fairly adduced as a test of their secret admiration. In conclusion, after noticing some of the recent painters who had done honor to Venice, such as Tiepolo, Piazzetta, \&c., the miter predicts the future fame of a young sculptor of twoand-twenty, who had just gone to practise lis art in Rome: this was Canora.

* The dedication is dated 1782. The Italian translation of some of Reynolds' Discourses appeared in Florence in 1778.

$\dagger$ Among other circumstances, the writer states that there is in the Corsini Library in Rome the first edition of Vasari, with marginal notes by Agostino Carracci, who, it seems, could not refrain from expressing his utter dissent from the Florentine historian respecting the Venetian painters. 
Venice has, in rery recent times, found enthusiastic adrocates who have warmly defended not only the genius of her painters but eren her government. Without further considering the perfection of the art itself in Venetian hands, it may be asserted that if ever a race of painters could be said to have been inspired by religion and patriotism above all other feelings, it is in the bright epochs of Venetian history that we must look for the highest examples. And withont entering into the consideration of this remarkable State we may agree with the eloquent French writer** who traces the high character of its art to the above causes, and follow him in quoting a similar expression of praise from an enlightened countryman of our orn. $\dot{\dagger}$

\section{"Joy is mine}

That I have read and learnt thee as I ought, Not in the crude compiler's painted shell, But in thine own memorials of live stone, And in the pictures of thy kneeling princes, And in the lofty words on lofty tombs, And in the breath of ancient chroniclers, And in the music of the onter sea."

This riew of the opinions of Vasari is only intended to put those on their guard who have not leisure to consult other authorities, which, it must be admitted in general, are far less amusing. $\neq$ As Reynolds has been followed by many of our own critics, so the Tuscan writers, from Borghini to Lanzi, have agreed with Vasari in giring the palm to Florence.

We assume, at present, it is to be remembered, that

* "C'est une vérité historique incontestable que Tenise, malgré tout ce qu'on a peut dire de ses tribunanx secrets, de ses courtisanes célébres, et de sa machiavélisme commercial, a été la plus chrétienne des republiques."De la Poésie chrétienne dans son principe, luns sa matière, et dans ses formes. Par A. F. Rio, vol. ii., p. j28.

$\uparrow$ Richard Monckton Milnes, now Lord Houghton.

$\ddagger$ Among the opponents of Tasari, Boschini, as far as he goes, might bid fairest to rival him, but for the circumstance of his having written, as we have unticed, in the Tenetian dialcet. 
the Amateur camnot dispense with anthority - that the opinions of others are among the inducements which win his attention to works of art, and teach him to exercise his observation. Insensibly his independent judgment is formed, which may or may not ratify the conclusions of others; but it is quite just and natural, while he rests on authority, that he should suspect those opinions which are likely to be prejudiced, or are arowedly exaggerated. The partialities of Vasari, after all, agree more nearly with general opinion, than those of most other eulogists. Thus Ariosto in distributing the meed of praise and fame to the most distinguished painter's, inchndes the two Dossi of Ferrara, because they were his fellow citizens. Lomazzo, a Milanese, enumerates seven great painter's, whose statues of varions materials grace his allegorical Temple of Painting. Most of the names are of the best, but Polidoro and Gaudenzio Ferrari are included, and both were from the territory of Milan. Tassoni, the author of the "Secchia Rapita" in his "Pensieri diversi" institutes a parallel between ancient and modem art, and challenges antiquity to rival eight painter's whom he names. In so large a comparison it was likely he could be tolerably just, and he is so, for he inchudes Albert Durer with the best Italians, and the first on the whole list is Titian; but Parmigianino is added to Correggio, and this is easily traced to the circumstance that Tassoni was a native of Modena.

Having alluded to the influence of writers on art so recent as Reynolds, we venture to approach still nearer to our own times in briefly describing a revolution in a great measure the effect of the opinions of literary men, which las taken place in Germany since the time of Mengs. The immediate successors of that painter, however preferable in the opinion of many to their more celebrated predecessor, can hardly be said to have proposed an object distinct from the imitation of the Italian painters and 
the antique statues. Various incidental causes concurred to produce the change in art of which we speak, but patriotism seems to have given the furst and mightiest impulse.

The destruction or spoliation of churches in the cities and townships of the Rhine during the wars immerliately following the French Revolution, were the means of dispersing the examples they contained of early German and Flemish art; and as those works had rarely attractions enongh, maltreated as they were, to tempt the avarice of invaders, they were, in many cases, rescued or cheaply redeemed by those who understood or felt their worth. Some were, by a timely precaution, removed or concealed, but, in most instances, they were ultimately sold to supply the losses which the derastations of war had occasioned to the religions communities. Such was the origin of those interesting collections of early national talent which were destined to produce so powerful an impression on a deeply sensitive people. The same pictures, in their original places, while a part only of the impressive decorations of the churches and chapels, and obscured probably with dust and smoke, had awakened no other feelings than those comnected with their situation and religions purpose, but when displayed for themselves as works of art,after the injuries of time or violence had been repaired, -a crowd of emotions and associations overpowered the beholders. With feelings of patriotism intensely alive at a time when the defenders of the country were battling for existence, the eyes of all were suddenly opened to the forgotten or mheeded excellence of their forefathers in the arts of peace-arts devoted to the service and embellishment of religion. That these works should have been brought $i_{1}$ to notice at such a time and from such a cause, aroused, as may be easily imagined, the most passionate predilection for the genius of their comtry, and whatever may have been 
the effect in stimulating patriotic ardour during the conflicts that took place in sight of their cathedrals, the admiration we speak of not only outlived the political struggle, but laid the foundation of a total revolution in taste. With such feelings at such moments, nay, even with the loftier and more comprehensive aspirations to which they lead, there are few perhaps who would not sympathise. Who has not regretted that the young nations of the midlle ages had not time to expand into free maturity before the revival of a classical influence hastened their development at the expense of a characteristic physiognomy? Who has not asked what language, what habits, what principles of taste wonld Tentons or Celts, - would Christians generally have arrived at if left to themselves? That such a curiosity is natural and such speculations admissible will forcibly strike us in surveying the beautiful examples of Gothic architecture. It is then we indulge the wish that all that Christian races have thought and done conld harmonize as completely with their own condition and being; for, although they might never have rivalled the plastic genius of pagan antiquity, they would have infused the spirit of their religion even into the arts by endeavouring to kindle or encourage the feelings which connect this world with another; above all they would never have applied what, in a given state of things, is beantiful and true, to other circumstances and habits with which they are incompatible.

These ideas, which are but fond imaginations to most of us, if indulged at all, to a German may easily assume plansibility and consistency. It is only in the German nation that the question as to the possibility of all independence of classic trammels can be for a moment entertained; for in language and art, as well as in Religion they may be considered the natmal antagonists of the classic ancients. At the period alluded to this question was chiefly agitated with regard to the imitative arts: the proposition was put whether the Germans should follow up the 
original character of their art, imperfect as it was allowed to be, or whether they should continue to borrow from a foreign nation and a remote period. It is not our necessary purpose to follow the exaggerations (if affected simplicity and dryness can be so called) to which these speculations led, nor to trace the expansion of this enthusiasm into more rational views and practice. 'The first effect on art was not produced without the co-operation and stimulus of sincere and eloquent writers. Friedrich Schlegel is generally allowed to have been the first in order; his descriptions of the pictures above alluded to, and his exhortations to men of letters and artists appeared in the "Europa," a periodical work published at Vienna in the first years of the present century.

Two productions of 'Tieck, or of 'Tieck and Wackenroder together, may be mentioned next. In one of these we are transported to the times of Albert Durer and Lucas Van Leyden; the hero, Franz Sternbald, is Durer's scholar, and the introduction of artists of the time, the description of their occupation, habits, and opinions is mingled with the aspirations and misgivings of Sternbald himself. 'The greater part of this composition, while the scene is in Germany, exhibits a passionate interest for the epoch of the actors it commemorates, but the latter part of the German pilgrimage and the whole Italian portion is very inferior, and betrays a different mind and hand. Another work attributed to Tieck and Wackenroder, but probably the work chiefly of the latter, consists of Essays, or, rather, as it is called, "Outpourings of the heart," on various subjects comnected with art. The homage to Albert Durer is here again a prominent sentiment, and it is to be remarked that this was the natural transition from Schlegel's admiration of the still earlier German painters. The description by that writer of the altar-piece of the Cathedral at Cologne, painted about 1400, is a remarkable proof of the influ- 
ence of enthusiasm; and, in comparing the eulogium with its object, we are forcibly reminded of the weakness of language in conveying a true idea of a work of art; for the same terms in which he describes a performance belonging to the infancy of art, might be applied to an example of its most consummate perfection. Some of the Essays in the "Outpourings of the heart" are founded on Vasari's historical testimony ; the incidents are selected unfortunately, being unfounded in fact, such as the story of Francia's death. But among the more interesting and original fragments is a disquisition entitled "Two Languages," viz., Nature and Art-in which these two are not mutually contrasted, but are together opposed and compared with all other language, and shown to have their independent, if not their superior powers and influence. This is one of the notions and expositions which stamps the author as an accurate reasoner, and best exhibits the depth and refinement of his taste.

It has already been observed that after the discovery of engraving on copper many subjects were treated in that mode of representation which seldom appeared in painting. But the art of wood-engraving, from its early connection with the embellishments of books, was still more universal. It is true these accompaniments were sometimes introduced as scientific explanations in works relating to anatomy, mechanies, \&c., but they were quite as frequent as mere decorations. Printing, from the first, was naturally allied to an art so similar in its preparation and process as mood-engraving, and hence the graphic ornaments of books by woodcuts may be said to be coeval with printed text. In missals and devotional books the representation of the Saints and other religious subjects were indispensable: people had long been accustomed to them in their manuscript prayer books, and such aids to devotion were then considered as important as the orisons they accompanied. This application of wood- 
engraving naturally led the way to the embellishment of books in general: the presses of Florence, Venice, and Lyons, vied with each other in this literary lnxury, and the specimens themselres throw additional light on the practice of the schools from which they spring. A curious gallery of art might be formed from the embellished books of the 15th and 16th centuries, for the designs are always original, and, in their compositions, seldom resemble any existing pictures. Many of them, again, exhibit the best qualities and powers of wood-engraving: as this art preceded engraving on copper, the first specimens of the latter have a close resemblance to wood-cuts, especially in the firmmess of the ontline. In modern times, as is well known, this inHuence has been reversed, for wood-cuts now attempt to gire the richness of metal engraving. When books were the work of calligraphists, and their embellishments drawn, coloured, and filt by hand, the best artists often employed themselves in the illuminating department. In the early midale ages this was indeed the chief practice of the painters, and even after Painting had made considerable progress, and the demand for altar-pieces was general, such artists as Fra Angelico, Memling, and others, occasionally exercised their talents in this way. But when wood-engraving was introduced, the final execution and eren the invention of the designs was seldom the work of the best artists. At least, this was the case in Italy ; in Germany, on the other hand, the finest talents were still employed in these productions, as the works of Holbein, Albert Durer, and others prove. Still, the Italian embellishments are strongly marked by the character of the school from which they spring, and often exhibit great beauty of composition, and great intelligence of the figure. A powerful school of designers, uncler Primaticcio, Nicolo dell' Abbate, and Il Rosso, was, as we have seen, naturalised in France in the first half of the 16th century, and the artists continued their labours moler 
Francis I. and his successor. The embellishments of the books published in the presses of De Tornis, Rovilio, and others at Lyons during the 16th century, have the general character of the painters above mentioned, with a certain Italian mastery in treating the figure. 'The woodcuts from the designs of Venetian artists seldom fail to convey an impression of colour; not indeed in the sense in which that power is fiequently understood in modern engraving, but by giving an idea of transparency, by opposing great strength and sharpness in the ontlines, markings, and clear shadows, to the reflections and lights, which have thus a sparkling effect, and resemble that internal light which is the great excellence of the Venetian and indeed of all well coloured pictures. The same principle is observable in the wood-cuts of landscapes, which were more coarsely done in Venice than elsewhere. But when this quality was lost in Venetian wood-cuts it must be confessed that they have little else to recommend them; whereas the designs of the other Italian Schools long continued to be respectable from the knowledge of form they displayed.

But, in spite of the public demand, and the frequent intercourse with artists, the publishers of those days appear to have been far less enlightened than our modern editors. An early edition of Ariosto is remarkable not so much for the wood-cuts as for the preface in which they are described; by which it appears that the grossest ignorance on the subject of painting was possible among these publishers of embellished books even at a time when the greatest trimmphs of the art had been achieved. 'The writer in question observes that a great improvement in perspective will be perceived in the designs he recommends, for that many objects are introduced getting smaller and smaller up to the top of the picture. He admits that on the page of the book the figures lie flat, but he informs the spectator 
that, notwithstanding this, they are, by an effort of the imagination, to be conceiver as standing upright, \&c.* If such a passage as this were found in any classic author, we might hastily conclude that it indicated a period when the arts were sunk in the completest barbarism.

The consideration of the influence of politics on the arts, naturally learls to that of the habits and manners of a people; effects connected more or less with the nature and operation of Government and laws. The fluctuations in all that constitutes the external evidences of general opinion and taste belong as much to time as to place, for the same country, not only in the lapse of centuries, but sometimes in a much shorter interval, may undergo great alterations in characted. In violent and temporary changes the arts will perhaps be a more faithful and lively record of public feeling than any other language, for it is to them permitted to be enthusiastic; the passionate expression of excitement which is lost for the historian, lives in such effusions as the Marseillaise Chant. All that belongs to the intenser, deeper, and raguer affections, to the loftier imaginations of a people, whether the times be good or evil, will display itself best, if not exclusively, in the arts; and they are then especially interesting when they express feelings which cannot be conveyed in any other form.

But the impression of national character is to be traced where its indications are less pronounced; and the habit of observing this will be found one of the most pleasing speculations to which the cultivater amateur can rlirect his attention. Even in the silent arts, the observer is again reminded, it is not necessary that the subject itself should be characteristic of a giren moral state-though this has sometimes been the case-it is in the character and demeanou of the actors that the habits of thought and the

* "Orlando Furioso," printed in Venice, 1566, by Valgrisi, edited by Girolamo Ruscelli. 
manners of the age are to be recognised. The dignity and almost solemnity of mien which are remarkable in all the works of the early Italian painters is not entirely to be explained by the religions subjects ther treated, nor by the possible inability of the artists to give gayer and lighter expressions; for we find the same sedateness very general in the highest derelopment of ant; and it is remarkable that the first exceptions are not to be found in the schools which aimed at the fascinations of colour, nor in festive subjects, but in the Holy Families of Florentine painter's. The general character of the productions of the 15 th and beginning of the 16th century, is grave and quiet: the grandeur of M. Angelo is perhaps truer to his own mind than to any time or place; but the apostles and philosophers of Raphael and the "dignified Senators" of Titian correctly express the Italian manners which belong to this age. This character is equally apparent in the portraits by those two great painters and by Sebastian del Piombo-these, uniting great tranquillity of mien with a look of inward life, are often true to the heroic age of Italy, and recall the Italians whom Dante dèscribed-

\footnotetext{
"Nel muover degli occhi onesta e tarda-

Ella non ci diceva alcuna cosa, MIa lasciavane gir solo guardando A guisa di leon quando si posa."
}

The manners of the noble Italians of abont 1500 still partook of this character, and they have been defined with sufficient minuteness by Baldassare Castiglione in his Cortegiano. The scene, as alluded to before, is the polished Court of Urbino in the time of the first Guid'ubaldo (Montefeltro), whose duchess, Elisabetta Gonzaga, was celebrated even among the noble dames of Italy for the perfection of her manners. The company which assembled daily in her apartments, after the visit of Julius II. in 1506, was composed of the most 
distinguished cavaliers, and the most accomplished litterati of the time. All are represented as conforming themselves in the midst of their hilarity to the example of tranquil dignity ("d'una graziosa e grave maesta") which was so remarkable in their high born hostess. In describing the manners of the ideal Cortegiano, one of the interlocutors instances the Cardinal Ippolito d'Este as the example worthiest of imitation; observing that, even in the presence of older prelates, being roung hinself, that nobleman had so dignified a mien, that he seemed fitter to teach other's than to need instruction. "In like manner," continines the speaker, "in conversing with men or women of whatever rank, even in jesting, in langhing, and in repartee, he maintains a certain calmness," \&c. This tranquillity of mien, however different from modern experience of the manners beyond the Alps, was more or less prevalent in Italy in Castiglione's time, and, as the acknowledged tone of refined society, may be supposed to have been more marked in Ferrara, Mantua, and Venice, in which places, as in Urbino, the example of the Court or higher orders would be more immediate. Rome, from the variety of its visitors, and Florence from the perpetual changes which preceded the established rule of the Medici, wonld be less certain representatives of the habits of the age. "It is pleasing;" says Castiglione, "to see a youth, especially if in the profession of arms, inclined to be grave and taciturn; self-possessed, without that restlessness which often accompanies early life. So collected a mamner (in a warrior) commands respect as proceeding less from anger than deliberation, and rather governed more by reason than impetus. Besides, it always bespeaks a magnanimous nature, and we recognise it even in those animals which surpass other's in nobleness and force, as in the lion and the eagle." This imaginary picture exactly corresponds with that of many a pale-faced, determined, and thoughtful 
Italian, as exhibited in the portraits of the time; for although Castiglione himself confesses that the glory of the Italian arms had declined, the rery confession is intended to excite the patriotism and knightly virtnes of his noble countrymen.

T'he expression of calmmess in clanger, in works of art, is a remarkable test of mational habits, or of the enthusiasm of particular periods. The characteristic of the ideal hero in ancient and modern times is the superiority of the will to external influence; a calmmess so lofty as to be abore the atmosphere of the passions. In Greece this was extended in art, and perhaps, by the force of habit and example, in real life, to extreme circumstances of action and dinger. The Greek hero or dirinity is always self-possessed; and not only in statues where there were other reasons for limiting the violence of expression, but in other modes of representation, as in the paintings on rases, the features are in a great degree tranquil and the eye calm in the last emergencies. 'This never obtained in modern art in an equal degree, till arlopted by the French school under Napoleon. 'The French hero then, on the stage, and in pictures, fonght, diel, or conquered with unruffled features, and with unkindled eye. Even now it would be considered a libel on the sangfioid of a French soldier to represent him, in whatever peril or however bent on revenge, with eyes flashing fire like a wild animal.

How far this is true to refined nature, so as to be understood as its expression in imitation, we need not stay to examine, but merely remark that, of Italian painters, the Venetians seemed most to aim at this calmness of expression in the representation of their heroes. Leonardo da Vinci, Raphael, and Giulio Romano (especially the first) seem to have given the matural expressions of rage and fear without restraint. 'The molern Frencl taste is to be traced in a great measure to the imitation of the classic models of 
art and to the Spartan rirtues of the Revolntion, for we should look in rain for the same quietness of expression in their pictures of battles executed two centuries ago, when the nation was quite as brave, and perhaps more refined.

In observing the gradual development of the powers and direction of the art, the change from the grave to the cheerful, and ultimately to the ludicrous, may seem the natural consequence of a full acquaintance with the capabilities of imitation, coupled with the desire to do what had been previously untried. That such should be the mere result of time when sufficient liberty of opinion exists is quite natural, lut the moment of change is generally found to be owing to a corresponding "modification of manners. In many countries sufficient liberty of opinion did not and does not exist, as in ancient Fgypt, and in modern India and China; and so, in the Papal dominions, in Venice and the more arbitrary States in Italy, the influence of religion and laws rendered changes comparatively gradual and the operation of opinion slow: but in Florence there were two causes which tended for a time to enconrage innovation and to undermine the influence of religion. These were the Democratic government, and the taste for classic literature, mythology, sc. At present we allude only to the first.

At a time when the arts, exchusively devoted to religion, were tanght strictly to adhere to the forms and types, however rude, which custom and prescription had rendered venerable, even an unstable and disorderly freedom could have a salutary effect; for there is no saying how long the rigid and traditional modes of representation might have lasted but for the capricious liberty of opinion which characterised the Florentines, and which led them to break through established usage as readily as to expel their ruler's.

The first great innorator was Giotto; and it may be sufficient here to observe that with a genius which opened up the sounces of much that was accomplisher in the course 
of two centuries later, he nuited an independence of opinion which presents a sudden and riolent contrast to the prejudices and practice of his age. He lived in the most turbulent and fickle times of Florence, and when Dante spoke of him, the poet, after having witnessed the expulsion of his own enemies, had been banished in his tum. The inflience of the same license was afterwards apjarent where there was not the same genins to reconmend and justify it. While the painter's of the rest of Italy, and particularly of Unbria, Bologna, and Venice, bent their whole efforts to represent the sacred personages of the altar pieces with a heartfelt devotion which could not but be apparent in their works, a class of Florentine artists, uninfluenced by any feelings for the sacred subjects on which they were employed, aimed at a species of reality which scandalised the public. Especially was this the case when Fra Filippo Lippi copied the features of his Inamorata for a Madomna, so as to be generally recognised. Still, there were not wanting both painter's and preacher's who from time to time attempted to stem these abuses, by reviving and enconraging a religions aim in derotional pictures: and hence two distinct aims in Florentine art -the one devoted to external imitation, the other to the expression of an enthusiastic feeling; and there can be no doubt that their mutual influence tended ultimately to the benefit of the art.

The social manners of Florence under her demoeratic govermment, with probably much of the license, had something of the cheerful ease and grace of independence; and althongh the influence of this state of things altogether on art was far from beneficial with inferior talents and vulgar minds, it was in all cases necessarily tempered and modified when applied to derotional purposes. 'The introdution of sniling expressions in satered subjects by Leonardo da Vinci was a remankable innovation in the 
treatment of Italian altar pieces; for there is no approach to this practice in any other school before his time. Improring on the hints and attempts of a few Florentine painters, and of Verrocchio, his master, he carried this new grace to sudden perfection: it was diffused by Isorenzo di Credi and others in the Lombard schools, and attained the last degree of playfulness and beanty in Correggio. In this daring and pleasing novelty-daring and questionable as anplied to religious subjects-we immerliately recognise the effect of that fickleness of taste and contempt of precedent which distinguished Florence, at least for a time, from the other Italiam States. We may add that it was scarcely possible for the taste of an age to have a more powerful or more miversal lepresentative than Leonardo da Vinci; for, with a capacity for all that was esteemed worthy of attainment in his time, he may be said to have presented in his own person an epitome of the genins, the mental energies, the skill, and the accomplishments of Florence. It was under the influence of the same habits and manners, and partly in all probability from the example of Leonardo, that Raphael adopted the cheerful character which distinguishes the Holy Families he painted in Florence. His later works in Rome of this class were, for the most part, serious and dignified, while his earlier performances in Perugia were imbued with that neek, pensive, and ahnost sutfering character which has been allearly traced to a peculiar religious influence.

'The Venetian painters, always so agreeable, sometimes so cheerful in colour, and so remarkable for vivacity of execution, yet never indulger in the smiling expressions of the Florentine am Lombind painters. The school which most aimed at fascinating the eye is always "grave and reverend" in expression; and this character is not confined to devotional pictures, it prevails equally in festive subjocts. In these lattel there is a quietness of 
mien, and even a solemmity of look exciting associations which, in spite of the cheerful circumstances ostensibly constituting the sulject, border on the norial and pathetic. Giorgione's, Titian's, even Paul Veronese's musical groups are always serions. The expression of the two principal figures in T'itian's picture called the "Four Ages," in the Stafford Gallery, is a pleasing example. The musical party and the Bacehus and Ariadne, by the same master, in the National Gallery, are of similar claracter; even the Bacchanals and lancing figures in the last-named picture are sedate, and form a singulai contrast, the subject considered, with the smiling gaiety of Correggio's Madonna and Child. 'To attribute this peculiarity in the Venetian painters to want of power would be absurd : it might be accounted for in some degree by the predominant taste for breadth of local colour; as if these artists were unwilling to disturb the mass of the canation ly ruffling it with expression. But the chief cause is to be songht in the grave manner's of the people. It was impossible for the Venetians at all laised above the lowest ranks to encourage bodily activity. Few were the places in the city where a promenarle for its own sake cond be thonght of, and a slow and measured step must have been fittest for a flowing and half-oriental costume. Even their mamners on Terra firma went rather berond those of the rest of Italy in gravity; - - the mode of riding called "alla Veneziana" was criticised as being too stately. 'The religious ceremonies, and the solemnity of a mysterious goremment added a moral influence within a narrow circuit to the local peculiarities, and confirmed the sedate appearance and quiet, tranquil manners of the Tenctians. Their chief ammsement which, though not silent itself is the canse of silence in many, was musir. A letter exists which gives an acount of a "partie carrée" in Titian's garden in August, about 1530. 'The party consisted of Titian, the writer' Fiancesen Priscianese, Samsovino the sculptor, and Pietro 
Aretino. "Before the table was prepared, for the sm was still powerful though the place was shady, we passed the time in contemplating the excellent paintings of which the house was full, and talked of the beanty of the garden, which is on the further sicte of Venice, next the sea, in full view of the island of Murano, and other pleasing scenes. No sooner was the sun set than this part of the sea was covered with a thousand gondolas, adorned with beautiful dames, while soft sounds of roices and instruments were wafted to us till midnight, when we were at sulper." In this garden, the view from which was only bounded by the blue Friuli mountains, was the tree with round leaves which Titian hat introduced in the picture of the Pietro Martire. The instrumental accompaniments of the roice, above mentioned, were not limited to the lnte, as the modern reader would imagine, for we learn from the author of the Cortegiano that the violoncello was esteemed the fittest instrument with the roice. Eren four of these instruments, then a farourite concert, were still improved, he alds, by voices: the flute he disalplureves of.

The costume of the Cortegiano is directed to tend rather' to the grave and seclate, than to the "rain." "It appears to me," says C'artiglione, "that black, or", if not black, the darker hues have a more becoming effect in dress than any other colours. But this I understand of the ordinary dress; for over, and with anmour, gay and lively colours without doubt are more apruopriate. But eren in these I should desire that repose which recommends the Spanish nation so much." And elsewhere, "the Spaniards approach more nearly to the Italian character than the French; for that sedateness and gravity which is peculiar to the Spaniards aplears to me more fitting for us than the realy vivacity which is so generally apparent in the French nation." "There are many Italians," he continues, "who endeavour. to imitate that vivacity, shaking their heads in talking, 
making awkward bows while in motion, and walking so fast that a comier could hardly keep up with them-all which never succeeds with them unless, indeed, they have been educated in France, and have adopted these habits from their chillhood." From this it appears that the sedateness which is so general in the Italian pictures in the earlier part of the 16th century, was the true representation of the national character at the time, and that the first exceptions in Florence were also analogous to the manners of her citizens.

The ideas of beanty entertained by the Italians during the period of the perfection of the arts, might be supposed to be derived without reserve from the living examples by which they were surrounded, but in some particulars, either from the conditions of art, or the influence of fashion, they seemed to have preferred a deviation from nature-a deviation at least from their own immediate experience of nature. The preference which the poets have always shown for golden hair might pass for nothing, for, as we shall elsewhere endearour to show, the descriptive department of poetry is generally lendered effective by means very different fiom the conditions and necessities of the formative arts, and hence a poetical description is no anthority for the painter; but in the present instance the poets and painters lappen to agree, and black hair which is so common in Italy and so beantiful everwhere, being found in pictures to be only suited for very dark complexions, is hardly ever to be met with in the Italian paintings as the accompaniment of female beanty. The colour preferred by the Florentines and Lombards, and especially by the Tenetians, is undonbtedly the most hamonions that conld be adopted for a mellow carnation-being in fact a darkened degree of the rely sime hue, (rather gohten than red) which prevails in the flesh; so that it is not uncommon, in mnfinished Venetian pictures, to see the forms outlined with the same warm brown which is used for the hair. 'The taste was so miversal 
in art that it even seems to have led to the actual fashion for auburn and golden hair, to obtain which, in Italy, artificial contrivances were necessary. Among the woodcuts of costumes by Cesare Tecelli, the consin of Titian, there is a representation of a Tenetian lady altering the colour of her hair with chemical applications. She sits on the house top, in the hottest rays of the sum, her face being protected by a hat so contrived as to exclude her hair, and expose it to the light. Thus, there may have been a time in Venice when nature was made literally to correspond with the taste of the painters, though at present dark tresses are as prevalent there as everywhere else in Italy.

The taste of the Italian poets with regard to complexion is, however, willely different from the practice of the painters. Tulovico Dolce, who had frequent opportumities of conversing with ritian, and of ascertaining his opinions directly as well as through the medium of his works, observes that "extreme whiteness of tint is not so agreeable as a licher hue, and that rermilion cheeks and coral lips are to be aroided, since they give to faces in pictures the effect of masks." He adks that Apelles preferred carmations bordering on the browner, mellower hue; and that when Propertius fincls fault with his mistress for painting herself, the poet expresses a wish that she could exhibit in her face that simplicity of hue which Apelles gave to his beanties. This was the taste of Titian and his follower's, and is undonbtedly true to the general impression of Italian nature, although sufficient exceptions are met with to warrant the somewhat different treatment of Paul Veronese. But in that fascinating painter's works the pearliness and ruddiness of the carnation is often accompanied with the lightest goklen hair, thus proving that it was a taste not literally derived from Italian nature, howerer true it might be to a climate beyond the Alps. 
Indeed it is by no means impossible that the German taste, which, in colour at least, had always a powerful influence on Venice, may have had its share in some of these predilections.

'The finely pencilled eyebrows and high foreliearls of the Florentine Madomnas are to be traced also to the fashion for these peculiarities among the Italian dames. We learn from a passige in the Cortegiano* that both were the effect of art, and in this case it may be presumed that the painters followerl, rather than suggested the fashion. Castiglione, jurliciously placing those recommendations highest which do not admit of constant display, observes that beautiful teeth are an advantage in a lady. "because they are seldom seen." This seems indeed a proof that the "temperance and smoothness" he recommends existed to a great extent; but, muless the Italians are totally changed, unless they could boast with Lord Chesterfield that, thongh often smiling, they were never seen to langh, we must conchule that the Italian Aristarchus meant only to recommend this moderation, when he stated it to be so general among his comtrywomen. Some other leason may therefore be assigned for the fact that none of the Florentine, Roman, or Venetian painter's ventured to show the teeth; and even Correggio ean scancely be said to be an exception, so rane and so little conspicnons are the instances where he has done so. In very early works of art, always remarkable for general incorrectness and misplaced attention to detail, it would be less difficult to find examples. Jacobello del Fiore, an early Venetian, conscientiously painted st. Michael's teeth, and carefully finished the angel Gabriel's tongue. It will be armitted on all hands that, in many cases, the modern painter's have improved the smile of beanty by exhibiting what the

* "Quindi nasce l'acconciarsi la faccia con tanto studio e talor pena; pelarsi le eiglia e la fronte." 
taste of the age did not permit Leonardo da Vinci, Raphael and 'Titian to attempt. I.eonardo's Mona Lisa might have been more attractive still, if her dimples and laughing eyes had been accompanied by the mouth which Revnolds caught from Lady Hamilton. 
DIFFERENCE BETWEEN LANGUAGE AND ART.--THE BEAU'TIFUL AND THE SUBLINE. -REPRESENTATIONS OF THE SAVIOUR, \&e.

The arbitrary signs of which written language is composed may embody the subtlest operations of thought, but these signs, which vary with time and place, are totally meaningless till we have learned to connect with them the ideas they symbolise. The Plastic arts, on the other hand, however circumscribed in their means of expression, are immediately intelligible, and it is through their miversal language that History is sometimes verifier, while many a long preserved inscription refuses to give up its meaning.

'This immediate perspicuity or natural eloquence of the imitative arts is therefore one of their distinguishing characteristics, although the mere utility to which it may be applied is among the lowest as well as the most limited of their attributes. And it is on this perspicuity that their value and dignity will still be found to depend, even when emplgyed on subjects of imagination; for they can only be generally intelligible in addressing the eye when they express what is familiar to the majority of mankind, or, in other words, when they represent the grander and more generil characteristics of nature. If we seek to determine 
more accurately the characteristics which principally aid us to recognise a class of objects, we shall find that they consist in those which, being the more constantly present to our observation, are necessarily best remembered. 'They are then the most frequent, and may be therefore called the most permanent qualities of mature. It follows that a representation professing to be as intelligible as possible, would exhibit all the permanent qualities compatible with the general observation of nature, and sparingly admit those of a mutable kind. This would approach the lighest style of art, for the idea of beanty itself resides in, or at least accompanies, the permanent, the general, and the remembered characteristics of mature. Thus the most intelligible representation will also be nearest to the idea of beauty, and the means will be distinct in proportion to our wish to see our visions realised; that is, in proportion to their beauty.

The principle of perspicnity in addressing the sense is, thus understood, one of the most essential in art, and from its paramount necessity we find that the infancy and the perfection of imitation are more nearly allied in this respect than would at first be supposed. 'The first efforts at imitation in all nations are necessarily marked by an anxious attention to the essential characteristics of the object imitated, in order that it may be easily recognised; and the same qualities (with many more such) are carefully dwelt on in the perfection of art, as the means of arresting the idea of beauty. Now the qualities by which we recognise a class of objects are precisely those on which their relative beanty depends. Hence it is we so frequently find in the rudest specimens of ancient art, and in the earliest after its modern revival, the germs of a pure and genuine imitation,-germs which were afterwards ripened to perfection, and which still surpass in interest, becanse in truth, the porrerful but mistaken innorations of the decline of art, where this first 
and last requisite is wanting. The slow but ultimately unerring decision of mankind has condemmed these later imovations, and has at all times refused to consider that a genuine illea of beauty, in which the mutable accidents of nature are more apparent than the permament characteristics.

'The endearour to speak clearly and intelligibly to the eye thus laid the foundation of executive style and beanty, and the perfection of this language was attained when all the permanent and easily recogniserl qualities of the object were effectively expressed; and hence accident, as being least necessary for this purpose, was admitted latest in the course of Art.

But if the infancy and the perfection of art thus necessarily resembled each other in their physical elements, from the influence of the obvious desire of perspicuity, there is a wide difference in their moral elements, and in the end they respectively contemplated; for, howerer necessary it may be, as long as beauty is aimed at, that works of art should speak clearly to the eye, it is by no means desirable that they should compete with language by attempting to convey precisely the same ideas to all. The perspicuity of pantomimic arrangement and comnected action, so essential a requisite in the dramatic style of art, belong not to the end but to the means of imitation, and these, as we have seen, need to be clear and intelligible; but the lighest powers of art have an aim beyond this, and are so distinct from the mere exhibition of an action, that they may be fully displayed even where no story is told. It has been justly observed that in Raphael the story is merely a means to show the actors-not rice rersi. For if language can describe as accurately and more accurately than art the progress and circumstances of an event, it is evident that the power of telling a story cannot be considered as the proper end and aim of Plastic representation. 'That power' 
is not in short a moral element of art. It is a rehicle only, and, as such, as producing an immediate and intelligible impression on the sense, it is beyond the means of verbal description, inasmuch as successive detail is surpassed by simultaneous representation, and as intelligible imitation surpasses the conventional srmbols of language. But there is an ultimate object in art, heyond this vivid impression on the sense, which must be compared with the ultimate effect of language, and this will be found to consist in such impressions on the imagination as words cannot produce; this ultimate olject of art in short begins where the power of rerbal description ceases. Almost every part of a work of art is susceptible of an indefinable charm which language can never convey, and this rague impression on the mind beyond the intelligible appeal to the eve is the moral element of art. The truth of these observations will be better tried by examining more accurately the nature of the Plastic arts as distinguished from the means and end of Poetry.

It is supposed that the first attempts at writing were of the nature of the imitative arts. To write and to draw were at first synonymous; but while, on the one hand, the exact and concise methods essential to written language soon distinguished it from the arts of design, the latter established a character of their own by appealing to our more exalted sympathies, and thus gradnally neglected the humble office of supplying, to a rery small extent, the power of words. Hence it is one of the lowest offices of art to inform, and, on the other hand, those languages have least answered their end which have attempted to express complicated ideas by combinations of imitative forms.

The object of perfected written language is therefore to convey comparatively distinct ideas by forms ummeaning in themselves; the highest province of art is to meet indefinite ideas by distinct, imitative representation. Thus, 
in language, whether written or spoken, the sign of the idea is less intelligible (having, in fact, only a conventional meaning) than the idea itself; in the Plastic arts it is the reverse. In language, whether Prose or Poetry, the imagination may be said to be directly addressed, for the attention is so imperceptibly solicited by the senses in reading or listening that we are scarcely conscious of their intervention ; the operation of the intellect in comprehending the meaning of worts is, from long habit, efrortless and instantaneous, while the meaning attached to each word is, or rather is intended to be, the same to all minds. But, in contemplating a work of initative art, although the intellect undergoes, or should undergo, no effort, the sense is actively employed; and yet, however distinct and intelligible the object represented may be, the ideas it excites may vary in different minds, according to various capacities and associations. Thus the ideas excited by contemplating $\mathrm{M}$. Angelo's Prophets and Sybils, which are sufficiently definite in execution, are rague, vast, and poetical. The same may be said of the master works of sculpture, which, from the conditions of that art, are still more definite. In proportion as a work of art becomes more widely intelligible by divesting nature of localities and accidents, so its idea addresses itself more and more to the imagination. The direct inspection of nature is necessarily an examination of details of which the imagination retains the aggregate or arerage idea. The impression produced by a representation of this average idea will therefore be truer to the memory of the senses than to the sense itself, but the force of the impression will obviously depend on the clearness with which the representation is defined.

The poetry of art then cloes not consist in the indistinctness of the work itself, but in the ragueness of the impression produced by what it clearly represents. When the 
work itself is indistinct the imagination may be said to be almost directly addressed, inasmuch as it is less aided by the senses, and the style of the Plastic arts, as deduced from the above comparison with language, is thus obviously violated, unless there is a meaning in concealment, as in mysterious or sublime subjects. These, it is true, approach the style of Poetry, but there are resources still in the power of Painting which can enable it to maintain its independence, as will be attempted to be shown hereafter. In aiming at the Sublime the object of the artist is to excite the imagination; in aiming at beauty he undertakes to satisfy it. Distinctness necessarily accompanies the latter attempt, or the imagination would still remain unsatisfied, and the imitative arts would refuse to do what they alone have power to do; for the exhibition of beauty is their exclusive privilege. It may be observed that no distinctness would offend in art or in nature if it did not disappoint, disgust, or terrify ; and when an object is umpleasant from being too defined, it will either be because such a definition is not true to the appearances of nature, or because it is not beautiful enough to warrant such a display. In the art of sculpture this hazardous definition must, from the positive nature of the material, be attempted, and, in the same proportion its representations are far removed from ordinary and accidental nature, for the necessity of defining involves the necessity of beauty.

It is then apparent that the means and the end of the Plastic arts are essentially different, and that if it is the lowest end of the arts to inform, it is, nevertheless, the highest requisite of their means. And the same quality which would be more or less degrading to their moral elements is thus the very essence of their executive style. One of the highest efforts of art is to meet and realise imaginations of which we are already conscious - that general memory of nature in which the idea of beanty resides. Hence art does not so 
much inform us, as ratify to the eye what we know, for the abstract idea, although derived from nature, already dwells in the imagination. The degree, therefore, in which this dream of perfection is met and realised will obviously depend on the clearness with which the representation can be adequately defined; so that distinctness will ever increase with beanty, and thus the more umeal the idea, always supposing it to be pleasing, the more definite will be its representation.

The nature of the distinctness which Painting admits, the mode in which its representations are most intelligible, and the means by which it endeavours to arrest the idea of beauty, are considerations naturally reserved to the examination of the style of that art. It may be, however, at once observed that the distinctness proper to Painting is very relative, even in the highest exhibition of beanty, where there would be least necessity for concealment; but as the degree of beanty becomes less and less the necessity of concealment or mystery increases, till the limits of ordinary effects are overpassed, and the representation becoming more and more uncommon or accidental assumes some new character, and may be capricious, solemm, or sublime. 'There is only one exception where the extremes which art can embrace meet, and where beanty is accompanied with mystery ; the impression thus produced is of the roluptuous kind. The nature of this principle and this mion would be best examined in an attempt to define the style of Correggio.*

Althongh it is true that the representation of beauty is the quality of the imitative arts which is unattainable by Poetry, and that it must, therefore, chiefly constitute their style, yet it will easily be seen that other attractions are not excluded provided they do not usurp the place of beanty. For while deprecating all attempts to make one art do the

* See "Materials for History of Oil Painting," vol. ii. p. 301-3. 
work of another, yet absolute distinction and independence of style may be carried too far. Just as we find in the Italian opera the story is considered the mere vehicle for the attractions of the music; the language, which was originally intended to be aided in its expression and not superseded by the music, being too often treated as scarcely worthy of attention. Thus it is evident that the appeal to the affections of the heart which can be made by words is much more powerful than the utmost efforts of imitative art to the same object. This does not, howerer, exclude the passions from Painting, nor even from Sculpture, but it teaches how their effect can be made impressive, and how the independence of Plastic representation can be sustained by calling to its aid those qualities which are, on the other hand, beyond the power of language. The extremes of certain passions, such as anger, grief, fear, may be described in Poetry in all their vehemence, because the imagination alone is addressed and the senses are not shocked. In Painting (to take the art which admits most license) these extremes are necessarily modified, because they are immediately addressed to the eye; so that the necessity for beauty is ever in proportion to the appeal to the senses. Thus the poetical description would be one which conld not be represented, and the impression produced by the visible representation would be so vagne as not to admit of precise description.* The expression in the statue of the Niobe is of this kind: the moment precedes the death of the children, and consequently there is no intention to represent the subsequent metamorphosis; her expression is the real grief of a living woman, but modified according to the conditions of sculpture and the beauty of the subject. Ovid, on the contrary, describes and dwells upon all her maternal agonies, at the same

* Many expressions of Raphael and Correggio are of this description, although sufficiently distinct in execution. 
point of time, in the style suited to Poetry. The difference between the expression of the statue of Laocoon and Virgil's description has furnisher the grommwork of an excellent treatise on the different methods of Poetry and Sculpture.* Thus, whenever the arts address the feelings they still address the imagination more, and when expressions are so positive as to leave no room for speculation, but conver precisely the same violently defined idea to all, they depart from the style of the imitative arts, and depart equally from the idea of beanty. It is scarcely necessary to repeat that the indistinctness of the idea is not to be confounded with that of the representation of the idea, which, as we have already seen, is, as a general principle, definite in proportion as the object is agreeable. On the other hand, when the work is necessarily indistinct, as in certain subjects where impressions of terror are increased by mystery, the violence of expressions may be more fully hinted at because they are more dimly seen. The general principle is thus the same: the senses must never be shocked; distinctness requires beanty, and unpleasant forms require to be partially concealed.

Again, as there is a gradation in the outward appearance of the passions, considered separately, so there is a gradation in the distinctness and completeness with which they may be rendered in art. The expressions which harmonize with beanty, such as love, joy, benevolence, admit of full development. The opposite feelings of hatred, anguish, revenge, and terror are necessarily limited in their visible representation, and so proportionally of intermediate passions. Hence the impossibility of mixing passions which require different methods of representation; and hence the absurdity of expecting the spectator to imagine character's of one description to be under the temporary influence, only, of other and opposite affections. What is exllibited to the senses is

* Lessing's Laocoon. 
exhibited once for all. It is in vain we are told that what we see is not the constant character of the personage, or. that his form does not correspond with his moral nature. Langnage can do this at once, because, to the imagination, things past or future are as rivid as things present; where nothing is seen but by the mind's eye, all is equally apparent; but in risible representation the imagination concludes only to the unseen from the seen; from this there is no appeal. A poet can tell us that his mistress is lovely eren in her anger, which is easily conceived if we suppose slight variations in her expression, and more than one moment of time; but if meant of one moment only it would be the same as asserting that anger is lovely, which is absurd.* Yet such would be the absurdity if a painter or sculptor, when giving full derelopment to the passion of anger, should expect his representation to exhibit an amiable expression. Furies are described in Poetry forgetting their character and yielding to pleasing sensations; it is true a Fury in Painting, eren with an amiable expression and exhibiting some beauty, would not be a very inviting object with "snakes uncurled" still shocking the sense; but, supposing all disagreeable impressions removed, she would then no longer be a Fury, nor even with the addition of her dreadful attributes, as long as her expression differed from her customary character. A reflection of this kind perhaps induced the author of the "Laocoon" to assert that the ancient sculptors had never" represented a Fury; he was mistaken, but his principle is still true, for the necessity of defining obliged the sculptors of antiquity to make Furies beautiful.t A mutable expres-

* Statins and Valerius Flaccus have described an angry Tenus, and Lessing smiles at the surprise of Spence that no examples of the kind exist in the arts.

+ The author of this admirable work is less judicious when he examines how far deformity can be admitted in the arts ; in fact he treats Painting and Sculpture as equal in power, forgetting that Painting has the power of concealing as well as of displaying. 
sion is one of the extreme difficulties of art; the appearunce of a moment is strictly within the power of representation, but the expressions of two moments, into which there is a danger of falling, would at once defeat the artist's object. An expression which constantly varies agrees with the successive and continued power of language, and may therefore be said to be more poetical than picturesque ; but its changes are composed of separate moments, each of which will be much fitter for representation than for description; for the only quality attainable by the description which art could not reach, would be the abstract one of mutability, or rather of actual change.

It is apparent that the idea of abstract beanty which addresses itself to the imagination and which we associate with the rague and general impression of nature, is more or less opposed to those livelier feelings of srmpathy which are addressed to the heart. The mode then in which violence of expression may be reconciled with the aim at beanty is by the influence of a principle in some respects of an opposite nature. We have seen that to be consistent with the style of the arts beanty shonld predominate, but in Painting the degree of beauty which is essential to the pleasing impression of the work may be the result of large and harmonious colour, independent more or less of beanty of form; and thus the causes of admiration are in less danger of nentralising the canses of sympathy, inasmuch as they may be said to belong to different departments. Thus, there is greater latitude allowed to expression in Painting than in Sculpture, although it still has the limits which may be defined, as before shown, from the comparison with language. We immediately see that beauty in Sculpture depends on form alone, and that therefore in subjects of expression the two contradictory principles (beauty and riolent expression), aborementioned, contend for mastery on the same ground. Beauty 
necessarily predominates, for if (in Sculpture) excluded from form, it exists no where else, and the art would give up all pretensions to please.

But if, as we have seen, the admiration of abstract beauty is so opposed to our sympathy with suffering, we are naturally led to inquire how far Sculpture, consistently with its main object, has the power of affecting us at all; how far, in short, it can appeal to the heart as well as to the imagination. It will be found that it is only in the representation of childhood, where beauty is not of an abstract character, that this porrer can be attained; or united with impressions bordering on the pathetic. The exhibition of the wealness of old age is too remote from the idea of life, or its hope, and therefore too remote from that of beauty to be fit for the full display of the powers of this art.* The exhibition of age without its wealness, that is, with a nearer approach to beauty, united with some appeal to our sympathy, will therefore be the next degree in which Sculpture can address the feelings. The union of the pathetic with adult beauty will be the least successful. The conventions and conditions of Sculpture are too far removed from familiar nature to excite a lively feeling of compassion; we see suffering in marble with comparatively little emotion, and this is still more the case where the imagination is addressed by the highest degree of beauty, as in adult forms, for that will usurp all our attention. The approach to the pathetic in

* In another of these essays (see "Contributions," Essny 13, p. 368), we have attempted to show that the idea of beauty is as the idea of life. If it be pleaded that death itself may be represented in the arts with effect, it is readily admitted; but whenever death is pleasing, it is beeause it resembles life in repose-

“ Before decay's effacing fingers

Have swept the lines where beauty lingers."

The same noble poet, spenking of the shut eyelid, which might be taken for repose, adds, "Thought shrinks from all that lurks below." Death is therefore never agreeable as death; it must be associated with beauty that is, with the attribute of perfeet life, to be so. 
Sculpture will therefore be in proportion to the departure from the abstract idlea of beauty; and it is needless to repeat that such a departure is very limited. In the Group of the Laocoon it is remarkable that the figures approach age and childhood as far as is compatible with a considerable degree of abstract beauty,- - the first condition of the art. Yet even here we hardly consent to the emotions which the idea of the sufferings we witness should excite. We feel that beauty is still the end, we admire rather than weep, and merely consider the dreadful circumstances of the subject as a means to display the real strength of the art. If we experience any approach to a lively sympathy it is for the children and especially for the youngest. But if the exhibition of pain and distress in Sculpture, while subordinate to beauty, can never affect our feelings much, it becomes much less limited than Painting in employing such subjects. The group called Arria and Pretus, a dying woman, and a man in the act of stabbing himself, may be looked at not only without emotion, but with that degree of admiration which its approach to beauty warants. It is not that the illusion is destroyed, but that illusions of this kind can never be produced except in the degrees and in the cases abovementioned. The conclusion then is that we are not so much shocked by the exhibition of suffering in Sculpture as by the want of beauty. In Painting it is different; for let us suppose the subject of the Laocoon painted-the serpents with all their terrific reality-the victims in their deadly agonies-and no beauty of forms or colours would atone for the harrowing impression. But we should hardly give way to it, we should immediately smile at the iujulicious attempt to torture our feelings, and thus art would sustain its worst defeat.*

* An examination of the theory of Arehiteeture, which can only imitate the principles of Nature, would lead to an investigation of the eanses of beauty itself - the qualities which always accompany it. This is the most 
After having thus considered how far the imitative arts can most legitimately affect the imagination, and under what restrictions they may appeal to the feelings, it remains to be examined how and in what degree they may safely pretend to address the intellect. It will at once be seen that this is the province of art in which language most surpasses it, and its efforts to this point will therefore be admissible in a less degree than Passion, and in a much less degree than Beauty. Of the various modes in which the intellect may be addressed in the arts, that will be the most genuine which depends less on the erudition than on the sagacity of the spectator; and that will be the lowest which absohtely informs him. Some attention is frequently necessary to comprehend the derelopment of a story in Painting, and a slight effort of the mind, if soon rewarded, is rather pleasing than not. Common consideration is generally sufficient to unravel any recondite ideas which need no previous learning to decypher them; but, whether requiring learning or not, the spectator who discovers a profound meaning will always rather admire than criticise the obscurity which his own discermment has penetrated. The allusions to costume, to obscure facts of history, and to science generally are obviously addressed only to the few, and therefore require to be sparingly introduced, but these may sometimes affect the imagination even when they are not understood, and if thus aiding the general impression of the work they may be considered genuine additions. It is enough, for instance, that the classic scenery and accompaniments which Poussin often introduces, give an impression of remote antiquity to his works; and what we lose, from being unable to trace all the scientific adaptation of these adjuncts to the circumstances and period of the

subtle and difficult inquiry connected with the arts. It is here we should most admire the sagacious and docile spirit of the Greeks, and find how deeply they had penetrated the essenee of beauty. 
fact represented, is abundantly compensated by the effect prodnced on the imagination. Indeed, it may be observed that these accompaniments in Poussin are more in the spirit than the letter of antiquity, for he is frequently incorrect in the mere scholarship of costume. But when such additions are so prominent as to excite curiosity, and thus remind the spectator of his own ignorance (moless mystery be the object) they are necessarily to be condemned. The display of those sciences which are connected with the arts is for the same reason justly censurable. They are supposed, as has been already explained, to aid the artist in rendering nature truly, and hence, when legitimately employed, are concealed in their results.

That exhibition of nature which, by representing the dress, labits, and objects of foreign countries and remote times, literally informs, ranks sufficiently low in the scale of art; but whenever representations of this kind are accompanied by large, true and familiar ideas of nature, the art again regains its dignity. The portrait of an nnknown Venetian nobleman by such a painter as Titian would be interesting to some persons as giring information as to the dress of the period; but, in spite of all its local and foreign peculiarities it would interest the admirer of genuine art as being true to larger ideas than such as have merely reference to a particular time, place, and person. Thus the idea of beanty, or that large view of nature by which a work of art becomes generally interesting, is indispensably necessary in some shape or other to every style of gemine art. The pictures by Bassano, and by most of the Dutch masters, would never be esteemed if they exhibited nothing more than the habits and mamners of their respective countries. The mode in which their effects are produced, and the idea of colour and light and shade which they exhibit, to say nothing of other qualities strictly constituting the style of Painting, are true to a much larger impression of nature than the 
forms of their dress and houses, and even of their figures. It must be adnitted that the degree of beanty which they exhibit is not extended to the most interesting point, and hence the mental pleasure they produce is very limited; but it is those larger qualities which give them the relative value they possess, and they are preferred to many works of art which profess to be in a higher taste, but which fail in the great requisites of Painting. An abstract representation of forn, without a large irlea of colour, is obviously destitute of style, and inferior to Sculpture.

We are accustomed to consider the Sublime as entirely distinct in its nature from Beauty, and it is only in their nearer limits where this distinction appears less palpable that we can, at first, hesitate to admit the general truth of the opinion; but it will be found to be true altogether. The difficulty of analysing and separating these two ideas is no proof that they are ever really identified, or that they can change their nature; and a discrimination of their doubtful limits will be best arrived at by keeping in mind the nature of the impressions produced by their more positive degrees. As the idea of beauty is associated with the objects of natural hope, (hife, health, vigour) so the Sublime is immediately or remotely comnected with awe and fear. The first (Beauty) resides in the general and familiar ideas of nature, the latter (the Sublime) is always more or less extraordinary. The causes of natural fear, the facts which our senses, beyond certain limits, shun, but which our imagination, within certain limits, can contemplate with pleasing dread, are associated with all the gradations of evil-from that which disturbs the tranquillity of a moment, to that which threatens life itself-and may thus vary in their effects from the overwhelming idea which annihilates resistance and extinguishes hope, to that molefined impression of awe which scarcely produces a sense of inferiority. We next perceive that the causes of fear may 
be divided into those which affect either ourselves or others - that we are either actors or spectators, and that the feelings we can thus experience arise either from the apprehension of evil or from the secure contemplation of it. The extreme degrees of such feelings would be absolute fear or horror; and they, as we have seen, are beyond the limits of the imitative arts. 'The feelings then, which the exhibition of danger or suffering as exhibited in art can legitimately excite are fortitude, or sympathy, or some modifications of them. But these feelings are by no means both allied to sublimity in an equal degree; it must be remembered that the idea of the sublime chiefly addresses itself to the imagination; for when compatible with distinctness it is accompanied with beauty, and when terrific it is reiled in mystery, so that in both cases it either indirectly or directly appeals to the imagination. But compassion, or sympathy, is an affection of the heart, and one of its softer affections; and it would thus appear that some idea of danger to ourselves is still necessary to distinguish the sublime from the pathetic; hence the only species of sympathy which is of itself allied to grandeur -or the Sublime-is where we are interested for fortitude itself; thus reducing the feeling within us to which ideas of sublimity are addressed to fortitude or elevation of mind alone.

The degree of fear, or rather of its causes, which are incompatible with definite representation are obviously beyond the powers of Sculpture. The effect of forms which offend the sense by their distinctness would only be terrible, if real, and even in nature we should remove them from our sight, at least by averting our eyes; but in imitative art, as before remarked, our imagination refuses to consent to the illusion. Repulsive subjects, on this accomt, frequently defeat their aim, for the moment we cease to go along with the conventions of the arts, what we see is no 
more than marble or canvas; and it would be indeed " the eye of childhood that fears a painted devil." The business of the artist is to make us cherish the illusion; in proportion then as the sentiment of fortitude is in danger of giving way to terror, the remoteness, indistinctness, or mystery which Painting can command, again make our dread pleasing. 'I'he curiosity we now feel is the test that we still love the danger. The senses are thus no longer shocked, and what would be ridiculous, because umreal, if distinctly displayed, excites the imagination while only partially seen. The impressions which are opposite to those inspired by the idea of beauty are therefore opposite in their mode of representation in art, and the principle is naturally applicable in the intermediate degrees; what is most displayed will be most beantiful, what is least agreeable will be most concealed. The degrees of the sublime and even of the terrible which are attainable in Painting are thus almost unlimited, but it must still be remembered that, as long as the senses are addressed, beanty, in some shape, must be the means of attraction. A picture which addresses the imagination directly by concealing forms in mysterious chiaroscuro, or by concealment of any kind, without a pleasing effect of colour, is an attempt at Poetry which is inferior to Poetry; and a picture which addresses the eye directly by definite and beantiful forms withont a large and true effect of colour is inferior, as has been said, to Sculpture, especially if it is not extensive in its composition.

The degree of fortitude or elevation of mind which can make danger pleasing, enables art to make that first approach to the sublime which admits of definite representation, and which thus may be attained in Sculpture. The art reckons, as it were, on this temper in the beholder; it can conceal nothing, and hence proportions its most imposing effects to the lofty feeling which can meet and feel familiar with their grandeur. This elevation of mind in the 
spectator is at all times necessary to the genuine effect of the sublime, and, as before observed, when it is in immediate danger of degenerating to fear, the illusion is destroyed, and the art has betrayed its interests by attempting too much.

The impressions of awe, reneration, and respect, produced by grandeur, dignity, and power are those middle qualities where the remote influence of fear is less immediately perceived. Fear, indeed, may be entirely orercome and banished from our minds, but if veneration and respect are removed it is not that we have the power of reducing ideas of awe and grandeur, but that we are capable of raising ourselves to their level; instead of bestowing our respect on the object it thus returns upon ourselves, and we feel enmobled for daring to familiarise our minds with sentiments which once oppressed us with a sense of inferiority. Thus in the arts, if impressions of the above kind are so conveyed as to orercome all that is oppressive in their effect, the spectator natmally rises to a level with the greatness he contemplates; and what really partakes of the Sublime assumes the character of exalted beauty, for such it is, as soon as it becomes an object of admiration. The idea of Longinus on this subject, although he speaks of Poetry and Oratory only, seems to be analogous, and is considered by Boileau to be a genuine definition of the Sublime. "For naturally," he says, "our mind elevates itself in some sort from the grandeur of expressions, and catching the ardour of enthusiasm, becomes filled with delight and complacency, as if we ourselves had produced what we have heard." Now the rery necessity of elevating our minds before we can fully admire, shows that there is a sense of inferiority; a remote principle of fear to be overcome; but it is no sooner orercome, the idea of greatness is no sooner made familiar to us, than we feel our superiority to our former selves, and we are conscious of being rather 
entitled to respect than susceptible of it. In fact, if ever an arful idea is really pleasing to a human being, lie must be, at least for the moment, possessed of exalted sentiments. The Prophets and Sybils of M. Angelo produce this elevation in many minds, and the feeling they inspire is justly compared by Sir Joshua Reynolds to what Bonchardon says he experienced on reading Homer; that his whole frame seemed to be enlarged. In these cases then it is not that the degree of sublimity is less; the work of art is unchangeable; it is that onr moral dignity and power are more. Our minds are therefore capable of converting sublimity into beauty by exchanging a remote degree of fear for admiration, but it will obriously be an admiration of an elevated kind proportioned to the change in our taste and sentiments. The truth of this will be at once perceived by reflecting on the possible and opposite perrersions of feeling, if feeling it may be called, which often result from the habitual contemplation of scenes repulsive in their nature. A field of carnage may, from long acquaintance with its circumstances, be viewed first with indifference and at last with pleasure. The applauding multitudes of both sexes that filled the blood-stained amphitheatre, and which still crowd a bullfight in Spain, prove that the sight of death and suffering may become agreeable. If the secure contemplation of the causes of our utmost fear may thus, by a morbid depravity of taste, become sources of gratification, it is obvious that the degrees of apprehension which are scarcely perceptible may, by a slight exertion of fortitude, be easily converted to pleasurable sensations. There are gradations of taste which are thus greatly in our own power, by accustoming our eyes and minds to higher or lower views of art and nature. We may descend so low in the scale as to admire imitations which have no pretensions to beauty, or we may elevate our minds so as to experience a sincere relish for the sublime. But, as before observed, whenever 
an idea of sublimity is regarded with the same admiration we pay to beauty, it assumes, for the time, the place of beauty in our minds; and thus a work of imitative art of an awful or grand character, if exciting this admiration, may be definite in execution, and if sublimity and distinctness are compatible, it is then, and then only, to be attained in Sculpture.

The first and simplest means by which Sculpture can succeed in this high object is by colossal size. If we can overcome the impression of inferiority in imagining ourselves in the presence of beings of supernatural power and stature, and this is always supposed, our minds naturally rise to a level with the conception; and a moral grandeur of sentiment within ourselves keeps pace with the physical power offered to our senses. Such representations, however, suppose manly beauty of form, together with power. The idea of the decline of life, the extinction of natural hope, is naturally associated with serious and solemm impressions, and thus, if not accompanied with weakness, if exciting sentiments of respect, is a degree of the Sublime. But the diminution of life is the diminution of the very idea and essence of beauty, and hence needs considerable modifications if represented in the art which is dedicated to visible perfection. The dignity, without the weakness or comparative deformity, of age, represented in a colossal size, would be the nearest approach to sublimity which Sculpture could make. The Jupiter of Phidias was accordingly the most sublime work antiquity had to boast; the age of the God in other representations which have come down to us is by no means advanced, at least there is no appearance of decline. The iclea of immortality, - of the God,-would be obviously destroyed by it. It is the redundant beard and extreme dignity of expression which alone convey the idea of advanced life. Yet these representations at once realise the Father of the Gods, and although he is without a wrinkle, 
we feel that we behold a venerable being. The variety of materials of which the statue of Phidias was composed might tend perhaps to diminish the grandeur of its effect, but the expressions of enthusiastic admiration bestowed on it by all the classic author's who have alluded to it, leave no doubt of its being the master work of ancient art. The sublimest works in Painting of a colossal and definite execution are unquestionably the single figures of the Cappella Sistina. 'The older figures in like mamner here exhibit the dignity without the weakness of age, but in a less abstract mamer than would be admissible in Sculpture from the different conditions of the arts.

It has just been said that the idea of sublimity results, in Sculpture, from colossal size.* The figures of Monte Carallo are an instance of this, for their forms are such as to excite admiration. A colossal Minerva or Jumo produces the same effect, for the idea of weakness which is associated with the sex is forgotten in a martial or dignified appearance; the association of divinity may be left out of the account, for it could never confer sublimity on a colossal Venus. The abstract idea of mere beauty and the feeling it excites are at once incompatible with the remotest sentiment of awe; gigantic stature would in this case only be sufficient to comteract a pleasing impression, without in any degree approaching the sublime. Many female statues of what is called the heroic size have come down to us; the clistance or height at which they were seen probably

* However grand the idea or subject may be, a statue less than nature can never be sublime. The reality of this art prevents our imagining the figure to be greater than it is. In Painting, unlimited space is often expressed by a skilful hand in the smallest dimensions; in Sculpture, at least in the round, no stretch of imagination nor any nicely calculated scale of comparison with still smaller objects can ever produce this illusion. In rilievo, where there is no longer any immediate comparison with the actual bulk of objects in nature, this illusion is more possible. A Hercules of half an inch high in a gem, gives a greater idea of size than a modil in the round of one or two feet high. 
reduced them to the size of nature, but this will hardly account for the enormous size of the Flora in the Naples collection; as it is now seen it is too gigantic to produce an agreeable impression, and too soft and feminine to be sublime. The most valued of the statues of Venus are about the size of nature, and the Venus de' Medici is ratler less.

Lastly, Sculpture borders on the sublime when even in ordinary or only heroic dimensions it conveys the idea of uncommon dignity, courage, or energy. Beanty is always, we repeat, supposed the indispensable condition of the art; a figure of the heroic kind which thus gives the impression of a rare and matchless physical organisation naturally excites elevated feelings, together with admiration. In making such an idea familiar to our minds, we feel that we have to rise to a level with the conception, but when we are no longer conscious of this process, when no remote degree of awe or respect requires to be met by loftiness of mind, then the traces of the sublime no longer exist. The work can then only pretend to beauty, and can only excite admiration.

It may be here considered how far ideas of highest reneration are compatible with definite representation, or with any representation. The person of the divine Founder of our religion is supposed to be a legitimate object of imitative art, whereas the visible personification of the Supreme Being is generally considered a vain, if not an impious attempt. The union of the human with the divine nature in the first case, and the possibility of exhibiting what was once present to human senses, is the usual mode of defending the representations of our Saviour. Yet, however free from impiety, it may be questioned how far such representations can be successful, and how far they can be consistent with the style of the imitative arts. It is evident in the first place that the idea is more impressive than any sign of the idea can be; and the superiority of 
this internal veneration once admitted, the representation becomes only a symbol, and cammot be expected to keep pace with, much less to be the cause of feelings of awe and devotion. That the beauty or dignity of the work of art has nothing to do in this case with a devotional feeling, is evident from the uncouth representations of the objects of worship which are so frequently to be met with in Catholic countries; where it will generally be found that those which receive most homage are the most uninviting to the senses and the imagination, as they are commonly the most ancient; dating from the infancy of art. In these instances then the object venerated is a symbol only; it is of a conventional nature, and thus partakes rather of the style of language than of the imitative arts. A work of genuine art professes to meet and realise our imaginations; and were this possible in representing the person of the Redeemer, it wonld with many persons really have the effect of inviting to atoration. This adequate representation is, however, fortunately impossible, not because sufficient beanty is not attainable, but because the idea does not at all depend on beauty; it dwells rather in our hearts and minds than in our imaginations; hence it again becomes less fit for the imitative arts, and hence the difference between the finest and the meanest representations is a matter of little consequence to those who adore such works as symbols, for symbols, it is obvious, they all equally are.

It must be admitted therefore that the attempt to excite many of the ideas which the contemplation of this subject generates, and, in particular, the utmost degree of veneration, by the analogous impression of a work of art, is vain and impossible. The idea excited by the highest notion of moral perfection, which language itself can scarcely reach, refuses to be presented to the eye in intelligible forms. But, althongh our minds can never be met in their high 
abstractions on this theme by visible objects, our hearts may be touched by them with sentiments of affection and gratitude. Abstract beauty is by no means an essential adjunct to produce such impressions; on the contrary, such feelings are allied to our near, everyday sympathies, not to that large view of nature which excites vague armiration; and one of the reasons why the representations of our Saviour are generally so insipid, is because they are addressed, or are attempted to be addressed, rather to the imagination than to the heart.

But if the attempt to convey an adequate idea of a perfect mind in a human form is thus impossible, how much more vain does the attempt appear to render palpable ideas of perfection which were never associated with the conditions of human nature. The difference, however, is less great than at first appears; it is enough that as regards the efforts of art both ideas are beyond its powers. In this respect, too, the difference between the powers of art and those of language is scarcely perceptible, and the means in which they best succeed in affecting us are the same. The mode in which the idea of the Divinity has been best rendered in art is by meeting feelings which are equally distinct from admiration and dread, from beauty and sublimity. The admiration or dread, the love or fear which a human being may feel towards his Creator, cannot be eren remotely excited by any visible representation; for if the mind fail to comprehend the nature of that Being, the attempt to embody that nature by an appeal to the eye is more manifestly rain.

The feelings which remain to be appealed to are then those which our human sympathies may in some measure represent. The lore, the reneration, the confidence, and the obedience which a father deserves and receives may be granted to resemble the relation in which the creature stands to his Yaker and Benefactor. What has beauty to do with the 
love we bear towards our parents? what the profounder comprehension of the duties of such a relation? The luman semblance which can touch us with the best and most serious feelings we experience towards a father may thus alone be suffered to represent our God. It is thus that the Bible represents Him; it descends to our sympathies. The Supreme Being is not there painted to our intellect nor to our imagination. He grieves, $\mathrm{He}$ repents, He rejoices; He has the visible forms and the ordinary speech of a human being. Who knows not that this is a condescending and conventional idea of the Deity, in order to reduce an abstract and incomprehensible notion to the moral wants and feelings of man ?*

It is merely intended by the foregoing observations to point ont the only mode in which the Deity can be represented. Most of the representations of the Supreme Being by Raphael and some of the earlier Italian painters are addressed merely to our unlearned and plain feelings, and

* Dante has made his celestial conductress explain the same idea, as follows :-

"Thus needs, that ye may apprehend, we speak :

Since from things sensible alone ye learn

That which, digested rightly, after turns

To intellectual. For no other cause

The Scripture, condescending graciously

To your perception, hands and feet to God

Attributes, nor so means : and holy church

Doth represent with human countenance

Gabriel and Michael," \&c.- “ Paradise," Canto IV.

So Milton :-

"What surmounts the reach

Of human sense, I shall delineate so,

By likening spiritual to corporeal forms,

As shall express them best."-" Paradise Lost," Book v.

"These passages," says Cary, "rightly understood, may tend to remove the scruples of some who are offended by any attempts at representing the Deity in pictures." 
hence, by avoiding the attempt at an adequate representation of the idea, are the most admissible.

It may be added that the limitations within which these ideas are to be rendered in Painting, exclude them still more from Sculpture. The representation even of the Saviour must necessarily fail in that art from the absolute necessity of beauty, and we have seen how little beauty has to do with the feelings required to be met. If then it be asked how the ancients were impressed with the representations of their Gods, it is answered that they were no more than personifications of abstract qualities in nature, and were thus necessarily addressed rather to the memory of the senses than to the heart or intellect. It was sufficient for a Pagan to admire his deity-the great object of his worship was Nature, and the representative image corresponded with that general impression of nature, which is at once a definition of beauty. This at least was the consistent idolatry of the Greeks.*

The arts then directly and adequately served the cause of religion with the heathens; and in perceiving that they are inadequate to that office as regards the objects of a Christian's worship, we have encountered a truth which it needed not this analysis of art to enforce. For how should abstract ideas of nature-and Nature is Art's only repertory-suffice to meet impressions which in their very elements are distinct from and above Nature!

* The Egyptians and other nations frequently addressed their personifications to the intellect. The attributes which can be comprehended, but which offer no attraction to the senses or imagination, were their cold allegories of Nature. The Ephesian Diana may be eited as a specimen. 



\section{DISCOURSE.}





\section{I S C O U R S E}

ON THE CHARACTERISTIC DIFFERENCES BETWEEN THE FORMATIVE ARTS AND DESCRIPTIVE POETRX.

Delizeral December 10, 1859.

Genthemen,

Is the remarks which I am about to offer I propose to resume a subject to which I have partially adverted in a former Discourse.

Recapitulating, by way of introduction, the elementary principle there affirmed, I remind you that in the observa tion of Nature and in the exercise of the eye, the chief aid of the Artist is comparison. The distinguishing attributes of each form and colour can be apprehended by no other means. In like manner the distinctive excellences of each Art can only be arrived at by an analogous process: the character of the Art will consist chiefly in those qualities in which it is found to differ from the other Arts.

To exemplify this process of comparison and its results I propose, on the present occasion, to offer some observations on the distinctive character of Descriptive Poetry, and then to show that a similar method is applicable to every branch of the formative Arts.

Two celebrated definitions have been deduced from the comparison of Poetry and Painting. The one, which is 
classical and ancient, is specious but false; the other, which is not older than the close of the last century, is only partly true; but although at once too comprehensive and insufficient, it contains the clue to a right discrimination.

The dictum ascribed, according to Fuseli, to Simonides, that "Painting is mute Poetry, and Poetry speaking Picture," is more lonourable to our Art than to Poetry; but it is strictly true of neither. Painting is not always " mute Poetry," and Poetry would be degraded indeed if it were restricted to "speaking Picture." The modern definition, which we gather from Lessing, is far more satisfactory. "Painting deals with form in space, Poetry with action in time." * To render this definition somewhat more accurate, we might say: "'The Plastic Arts represent objects in a quiescent or in an arrested state, in space; Poetry, when confined to the description of visible objects, dwells on the changes of those objects in time."

It is plain that comparisons can only lead to useful inferences when the relations of the things compared are palpable and appreciable. Hence we never can do more than compare Painting with a part of Poetry. Description, - the only department in which Poetry is in danger of entering into injudicious competition with the formative Arts, - is but a small section of the poetic world. Epic story, dialogue, moral reflections, philosophical arguments, and the whole range of thought, imagination, and allusion, cannot be approached by the arts of representation so as in any way to endanger the independence of poetic expression. This being apparent, the truth contained in Lessing's definition above referred to, may take its place in due order, if we begin with the more comprehensive form before proposed ; viz., that the excellence of any one of the Fine Arts

* “Laokoon, 8tte Auflage,” Berlin, 1805, §§ xvI. xviI. ; compare Anhang, $\S \mathrm{XLIII}$ 
will consist chiefly in those qualities which are unattainable by the other Fine Arts.

What then, following this guide, are the characteristic differences between the formative Arts and descriptive Poetry? for no other poetry can ever fear a rival in representation. This question I now proceed to consider.

First, with regard to the eye. When descriptive Poetry is literally nothing more than "speaking Picture" (and instances of such bad taste might be adduced), the description must be inferior to representation. A sufficient reason, among others, being that the risible impression is simultaneous and lasting, while each detail described in words is in some measure effaced by the succeeding image. I need hardly observe, that of all dangerous undertakings for the Poet none can be more so than the description of visible beauty, precisely because this is the point in which representation is, or can be, strong. I here use the word description in its literal sense: there are passages in some writers, professing to convey ideas of beanty, which are mere inventories, uninteresting alike to the understanding and to the fancy ; too inexact to inform, and too prosaic to excite the imagimation. You are doubtless most of you aware, from Lessing's excellent remarks, that Homer nowhere describes the beauty of Helen; yet, avoiding all ineffectual appeal to the eye, he contrives to convey the highest idea to the reader's mind. He tells us that when the old men, seated on the ramparts of Troy, saw her approach, they said to each other, "No wonder that two nations should have endured a long war with all its evils for such a woman, for she equals the immortal goddesses in beauty." * So far is this from being inferior to representation that we can hardly conceive an equivalent representation.

This is a well-known example of the modes in which the Poet can successfully describe beautiful oljects, even sup- 
posing them to be in a quiescent state; but when he renders forms or colours mutable he is altogether independent of the plastic arts. Although continuous action is impossible in those arts, the action which is supposed to be arrested in a passing moment is one of their triumphs. If, therefore, Poetry undertakes to describe visible objects, as such, their change of appearance from one state to another, their continuous action, is suggested by the principle above proposed. The Painter may represent figures or objects in momentary (which means in arrested) action, or in absolute repose; the Poet generally avoids the repose, and prefer's the mutable appearances which take place, more or less rapilly, in time.

The poetical descriptions which exemplify this are innumerable. I select a passage from Dante, which not only indirectly illustrates the principle, but amounts to a declaration of the Poet's creed on this point. He speaks of a sleep which overpowered him while listening to angelic music, and says that if he could describe the sleep which closed the eyes of Argus, when lnlled by soft somds-

"then, like painter,

That with a model paints, I might design

The manner of my falling into sleep.

But feign who will the slumber cunningly,

I pass it by to when I wak'd." *

As if he had said: "quiescent appearances may be fit for" painting, but the Poet requires the changes which indicate the lapse of time."

The principle itself is sound; for the rest, the question whether sleeping figures are necessarily motionless may be answered by Dryden :-

"The fanning wind upon her bosom blows;

To meet the fanning wind the bosom rose;

The fanning wind and purling streams continue her repose." +

* Cary's Dante, " Purgatory," canto xxxiI.

† "Cymon and Iphigenia." 
Thus, when we talk of a "graphic description" in a laudatory sense, we commonly mean a description of a moring picture-a description of successive appearances vividly and aptly represented by successive words; - we mean, in short, anything but what is strictly graphic; for a mere description of an immutable appearance would be unsatisfactory, because inferior to Painting.

The description of works of Art, which are unavoidably quiescent, is, on this account, one of the tests of the Poet's skill-at least as regards the more or less successful mamner in which he transfers those appearances into the domain of his own art; for I do not remember an instance of a mere description of a statue or picture, as such, nor can I conceive anything more unpoetical. Among the excellent modern examples of the kind may be mentioned Byron's, Milman's, and Shee's descriptions of celebrated statnes. On turning to those passages, you will see how completely independent the poetry is, and yet how worthy of the subjects described. The most ancient instance, often commented on, is Homer's description of the shield of Achilles - a description which, as you know, is full of continnous action and of qualities unattainable by the formative Arts.

One of the most daring examples of the translation, if I may so call it, of a work of Art into poetic description, occurs in Dante. The Poet is speaking of some sculpture in bas-relief on the white marble base of a precipitous rock. After noticing other representations, he comes to the wellknown subject of Trajan and the widow, which he thus describes :-

"There was storied on the roek

* * * * Trajan the Emperor.

A widow at his bridle stood, attir'd

In tears and mourning. Round about them troop'd

Full throng of knights ; and overhead in gold

The eagles floated, struggling with the wind.

The wretch appear'd amid all these to say : 
'Grant vengeance, Sire! for, woe beshrew this heart, My son is murder'd.' He replying seem'd :

'Wait now till I return.' And she, as one Nade hasty by her grief : 'O Sire! if thou Dost not return?" "

The dialogue contimues: the Emperor tells her that in that event his successor may avenge her cause. The importumate widow reminds him that it is for him to do right and not to delegate his acknowledged duty to another. The Emperor yields to her argument, saying:-

" ' It beseemeth well

My duty be perform'd ere I move hence :

So justice wills, and pity bids me stay." "

The Poet explains the manifest inconsistency of this description of a work in marble, as follows :-

"He, whose ken nothing new surveys, produc'd

This visible speaking, new to us and strange,

The like not found on earth." *

None will be disposed to question that fact; and yet it may be conjectured that Dante had seen something which may at least have suggested this poetic flight. During and before his time, according to Vasari, the practice was adopted, and sometimes abused, of inserting speeches over the heads of painted figures.t The application of this to Sculpture in bas-relief could be easily imagined.

With regard to the legitimate poetical artifice of describing inanimate or motionless objects by the aid of comparison, it is to be observed that the simile, in such cases, is commonly fuller than the subject which suggested it. In the mere mention of Satan's spear, Milton conveys no image which can degrade the description to a competition with painted still-life, and the Poet's simile removes it altogether from any rivalry with representation :-

* Cary's Dante, "Purgatory," Canto x. + Vasari, "Vita di Buffalmacco." 


\section{"His spear, to equal which the tallest pine Hewn on Norwegian hills, to be the mast Of some great ammiral, were but a wand, He walk'd with to smpport uneasy steps Orer the burning marle." *}

This mode of aroiding the literal description of inanimate objects is still more poetical when the simile involves an allusion to distant time, and to important events :-

\section{"It was an area wide}

of arid sand and thick, resembling much

The soil that erst by Cato's foot was trod." +

Thus Dante, apropos of nothing but sand, calls up in the reader's mind the long and painful march of the Roman patriot across the desert from Cyrene to Utica.

Such are some of the modes in which the description even of quiescent visible objects may be rendered poetical. I now proceed to the consideration of a wider range of resources by means of which Poetry, though still of the class called descriptive, may be entirely independent of the plastic arts; and here Lessing's definition is no longer applicable.

The mode to which I now refer is by addressing the other senses rather than, or together with, the eye. Indeed, after some investigation, I am tempted to conclude, that the prevailing principle with Poets, is to address any sense rather than the eye. I give you some passages from Shakspeare: the following two lines from the Midsummer Night's Dream are remarkable as illustrating much of this principle in a small compass:-

"And, in the spiced Indian air, bJ night, Full often hath she gossip'd by my side."

\footnotetext{
* "Paradise Lost," Book $\mathrm{I}$.

† Cary's Dante. "Inferno," Canto xIr.

$\ddagger$ Act II., Scene 2.
} 
The "spiced Indian air" is redolent of perfume; the gossiping is addressed to the ear; "by my side" implies the sense of touch ; "by night" that objects are indistinctly visible; and "full often" indicates the lapse of time.

In Shakspeare's descriptions of beauty, it will be seen how instinctively he adheres to the qualities which are the exclusive province of Poetry :-

"Admir'd Miranda

* * * Full many a lady

I have ey'd with best regard, and many a time

The harmony of their tongues hath into bondage

Brought my too diligent ear ; for several virtues

Have I lik'd several women; never any

With so full sonl but some defect in her

Did quarrel with the noblest grace she ow'd

And put it to the foil ; but you, O you

So perfect and so peerless, are crcated

of every creature's best." *

You will observe in these lines, first an idea of visible perfection without any attempt at the description of visible qualities; and next, a descriptive passage, addressed not to the eye but to another sense.

Compare the following description of Destemona:-

"If I quench thee, thou flaming minister, I can again thy former light restore,

Should I repent me: but once put out thy light, Thou cunning'st pattern of excelling nature,

I know not where is that Promethean heat,

That can thy light relume. When I have pluck'd thy rose, I camnot give it vital growth again,

It needs must wither :-I'll smell it on the tree,--

O balmy breath, that dost almost persuade

Justice to break her sword! " $\dagger$

Here again a vague impression only of visible perfection is conveyed, while the more special idea is not addressed

\footnotetext{
* "Tempest," Act III., Scene 1.

† "Othello," Act V., Scene 2.
} 
to the eye. In a precerling passage, indeerl, when Othello says-

"Yet I'll not shed her bloor,

Nor scar that whiter skin of hers than snow : "sc.,

We have a visible image; but that image is contrasted in imagination with another state, thus rendering the description more poetical. This power of alluding to an altered appearance, not yet existing, of the object described, is finely illustrater in Campbell's limes :-

"On Linden when the sun was low,

All bloodless lay th' untrodden snow."

Milton, in his description of the Garden of Eden, does not disdain the lowest sense, and reclaims the fruit " burnish'd with golden rind" from rivalry with Painting, by adding that it was "of delicions taste." " It may be added, that the metaphor's derived from this sense are numerous in Shakspeare.

In accordance with this feeling for the distinctive style of their Art, we find that Poets, in descriptive passages, have frequently dwelt on somds and perfumes, and on the sense of touch-eren as susceptible of the freshness or warnth of the atmosphere-rather than on visible images; at all events in preference to quiescent forms and appear. ances. In the lines of Gray :-

" The breezy call of incense-breathing morn,

The swallow twitt'ring from the straw-roof'd shed. $\dagger$

In those of Brron :-

"It is the hour when from the boughs The nightingale's high note is heard, It is the hour when lovers' vows Seem sweet in every whisper'd word, And gentle winds and waters near Make music to the lonely ear." + 
In such passages we recognise the style of poetic description; nor less so when Thomson tells of the leafy luxuriance

"Where the birds sing concealed." *

When Anacreon directs the "best of painters" to represent the undulating tresses of his fair one, like a true poet he requires impossibilities:-

"And if painting have the skill

To make the spicy balm distil,

Let ev'ry little lock exhale

A sigh of perfume on the gale." $\dagger$

In the description of sounds, Poets are alive to the charm of what musicians call crescendo and diminuendo. Thus Scott :-

"Some pipe of war"

Sends the hold pibroch irom afrr.

At first the sounds by distance tame,

Bieliow'd along the waters came ;

And, ling'ring long by cape and bay,

Wail'd ev'ry harsher note away.

$+$

Then bursting bolder on the ear

The clan's shrill Gathering they could hear." †

In the celebrated lines of Dante (for I pass from gay to grave) which translation cannot fitly render, the unlimited duration of the awful sounds described adds to the grandeur of the idea:-

"Here sighs, with lamentations and loud moans, Resounded through the air pierced by no star, That e'en I wept at ent'ring. Tarious tongues, Horrible languages, outcries of woe, Accents of anger, voices deep and hoarse,

With hands together smote that swell'd the sounds,

Made up a tumult, that for ever whirls

Round through that air with solid darkness stained."

* Spring. † †Loore's "Anacreon," Ode xvi.

¥ "Lady of the Lake," Canto Ir.

§ Cary's Darite, "Inferno," Canto III. 
Dante's predilection for what may be called the poetic elements of description is apparent even when he sceks to convey an impression of a scene in Nature. Here is a landscape by lim in this taste :-

"Forthwith I left the bank;

Along the champain leisurely my way

Pursuing, o'er the ground, that on all sides

Delicious odour breath'd. A pleasant air,

That intermitted never, never veer'd,

Smote on my temples, gently, as a wind

Of softest influence; at which the sprays

Obedient all, lcaned tremblingly

Yet were not so disorder'd, but that still

Upon their top the feathered quiristers

Applied their wonted art, and with full joy

Welcom'd those hours of prime." *

In most of these instances of the poetic style of description the sense of vision is not addressed at all, and undoubtedly the poetry is more exclusively poetry on that account. But I have already shown that the description of visible objects can be quite independent of any unfavourable comparison with Painting by a due attention to those poetic conditions which remove it from the character of "speaking picture."

I have thus endeavoured, by a reference to an important branch of Poetry, to illustrate the position-that the excellence of any one of the Fine Arts will consist chiefly in those qualities which are mnattainable by its rivals. I have dwelt the more on the department I have selected, knowing how much false criticism formerly prevailed on that subject; and I have been induced to illustrate more fully what I believe to be the true principle, in order that the method of comparison which I recommend may be more clearly understood and consequently more easily applied in other cases.

$$
\text { * "Iurgatury," Canto xxvir. }
$$


I invite you to pursue this method in your own respective Arts. For this purpose you may find it convenient to express the principle in a still more comprehensive form : thus-"Things being compared together, their character" and relative excellence will consist chiefly in those qualities which are exclusively their own." You will first bear in mind that comparisons need not be made between things totally dissimilar. The point is to distinguish an appearance or idea from those with which it is, or may be, in danger of being confounded. Thus, in expressing death in Painting or Sculpture, it is plain that what we have to aroid is the appearance of mere sleep. Characteristic plastic expression is one of the touchstones of an Artist's ability, and successful examples become types of their kind. We recognise the painter of genius in that figure of Ananias ;* the painful manner in which he has fallen on his contorted hand distinguishes the case from any ordinary fall, and expresses a sudden visitation, even without the eridence of the acts and emotions of the surrounding figures.

Turner, knowing the difficulty, as every Painter must, of clearly expressing an idea distinct from any other, was always ready to appreciate examples of success in this particular, whether in old or modern works of Art. He was even an observer of contrivances for the same end on the Stage. He had long maintained that it was not possible to express, on the stage, the bottom of the sea. On hearing that a new attempt of the kind had been made in some pantomime, he inquired particularly what were the means resorted to. Various incidents were enumerated, at which he shook his head. At last he was told that an anchor was lowered from above, by its cable, till it rested on the stage. He reflected for a few moments, and then sail, "That's conclusive."

* Raphael's Cartoon of the Death of Ananias. 
All who are conversant with works of Alt, nust have frequently noticed the ambiguties in representation which Painters sometimes unconsciously fall into. Nor is Sculpture free from such possible oversights. The Student should therefore ask himself what the figures he has put together really express. He should divest himself of preoccupations derived from other conceptions of the text he proposes to illustrate, and should even invite persons ignorant of the subject to say what the figures are doing. It would involve criticism on many works of Art, and would lead to a higher appreciation of others, if such productions could be described not by their nominal subjects, but by what they really express. We should sometimes find, on the one hand, that the personages represented were not only unworthy of their names, but that they were acting differently from what the story dictated: on the other hand, we should sometimes find a noble realization, and a world of beauty appreciable by the eye alone, which no verbal eloquence could adequately define.

The Poet exercises a power apparently unattainable by the Painter in conveying impressions of objects by means of similes. But let us look more closely into this seemingly exclusive attribute of Poetry. We find that if risible objects in Nature can suggest such elevating comparisons, the same objects adequately represented in Art may suggest similar ideas. The superior advantage of the Poet is that he can express the association as well as the original image, or rather, as we have seen, more fully: but it is not the less true that a worthy representation of the original object may kindle thoughts equivalent, and sometimes superior, to the Poet's similes.

The Painter should therefore ask himself, not only what does his representation really tell, but what is each depicted object really like. The best general answer to the second question, in accordance with the doctrine I have endea- 
voured to explain, would be-the object should be like its prototype and like nothing else. But, not to mention that there are appearances in Nature so vague and mutable, that they may almost be said to have a Protean character-such as the forms of clouds and distant mountains which are sometimes so interchanged as to be agreeably ambignous-not to dwell on these and such as these, including all the fairy transformations produced by atmosphere and light, we find that common incidents and objects, either under the influence of such effects, or in momentary states of beanty, may acquire a character far beyond their arerage reality ; and when this passing charm is canght and expressed in Art, such appearances really suggest poetic similes quite as much as the original phenomena, and with this additional recommendation, that the canses of the impressions are permanent. We all know how readily finely coloured pictures are compared to the purity of the pearl, the bloom of flowers and fruits, and the sparkle of gems; and we know that the imitation of the most common substances is sometimes felt to convey ideas of splendom, transparency, and harmony which suggest the most enthusiastic comparisons. We also know that in condemning false colouring, we say it is like clay, or brickdust, or mud. It is plain then that the world of similes is involuntarily resorted to in our judgment of depicted objects no less than in defining our impressions of Nature.

It may at first appear a truism to assert that things totally dissimilar are in no danger of being confounded. The cantion is indeed almost mmecessary with regard to forms, but less so with regard to effects of colour and light. 'Things very dissimilar in form may be so treated that their consistence, texture, and superficial qualities may be more or less confounded. For want of this discrimination, we sometimes see flesh that resembles porcelain, metallic drapery, soft rocks, and roolly armour. I again except 
those Protean appearances in Nature before noticed, the mutability of which is in fact their characteristic.

If the foregoing positions are just, it may be inferred that the representations of Art should always be either equivalent or superior to the object or idea intended to be embodied: further, that the superiority of Art to average Nature cannot be attained by exaggeration, but by the selection of farourable and sometimes momentary states. The criterion thus proposed would, in its application, apparently condemn many a celebrated work. Te shall find, however, that it sufficiently accords with the rerdict of time; for no Painter has achieved an enduring reputation who has not embodied truth in some sense-truth either ordinary or rare, either familiar or exquisite, or both-in some department of the Art.

One of the uses of a comparison of the different Arts is to guard each against the undue influence of the rest. As regards Painting there seems, at present, to be little necessity for any caution of this kind. Since the beginning of the century, when a Continental School was led into an exaggerated imitation of Sculpture, there has been a universal reaction, and the instances were rare of any of our own Artists being infected by the classic mania. The influence of Poetry has been more apparent, and at one time superinduced a rague and fantastic element which threatened the solidity and independence of our School in an opposite way. At present there is no complaint to be made of a leaning to either excess. The peculiarities which exist in Painting vibrate, at all events, within the limits of the Art, and are characterised by opposition to other modes of Painting, rather than by a questionable adaptation of the attributes of the other Arts.

I observe, in conclusion, that the principle of distinctive character, as I have endeavoured to explain it, is not without a personal, and, in some sense, a moral application. 
If the perfection of the Fine Arts depends on their developing, each for itself, the capabilities which belong to it-if nothing is gained, and if much may be lost by any one of them assuming the attributes of another; so the advanced Student, in aiming at distinction, should learn to be true to himself. For, if he seeks to be what he is not, to adopt the thoughts, the predilections, and the practice of others, without sometimes retiring into himself and communing with his own heart, his works will either be without character, or may be contaminated by affectation.

Let me therefore earnestly recommend you to preserve your intellectual freedom; and while you adhere to the essential elements of the Art which you may have chosen, and seek to reproduce in unequivocal representation the qualities of visible things, endeavour to adhere no less truly to your own feeling, subject only to the salutary modifications resulting from knowledge and experience. Nothing, however specious, which can be assumed in its stead, will secure you lasting success. On the other hand, the world, cold and indifferent as it may appear, will always recognise sincerity, and, (your sufficient ability being supposed,) will cordially accept that which is really your own.

THE END. 





\section{RETURN CIRCULATION DEPARTMENT}

TO $\rightarrow 202$ Main Library

\begin{tabular}{l|l|l}
\hline $\begin{array}{l}\text { LOAN PERIOD 1 } \\
\text { HOME USE }\end{array}$ & 2 & 3 \\
\hline 4 & 5 & 6 \\
\hline
\end{tabular}

ALL BOOKS MAY BE RECALLED AFTER 7 DAYS

Renewals and Recharges may be made 4 days prior to the due date.

Books may be Renewed by calling 642-3405.

\section{DUE AS STAMPED BELOW}

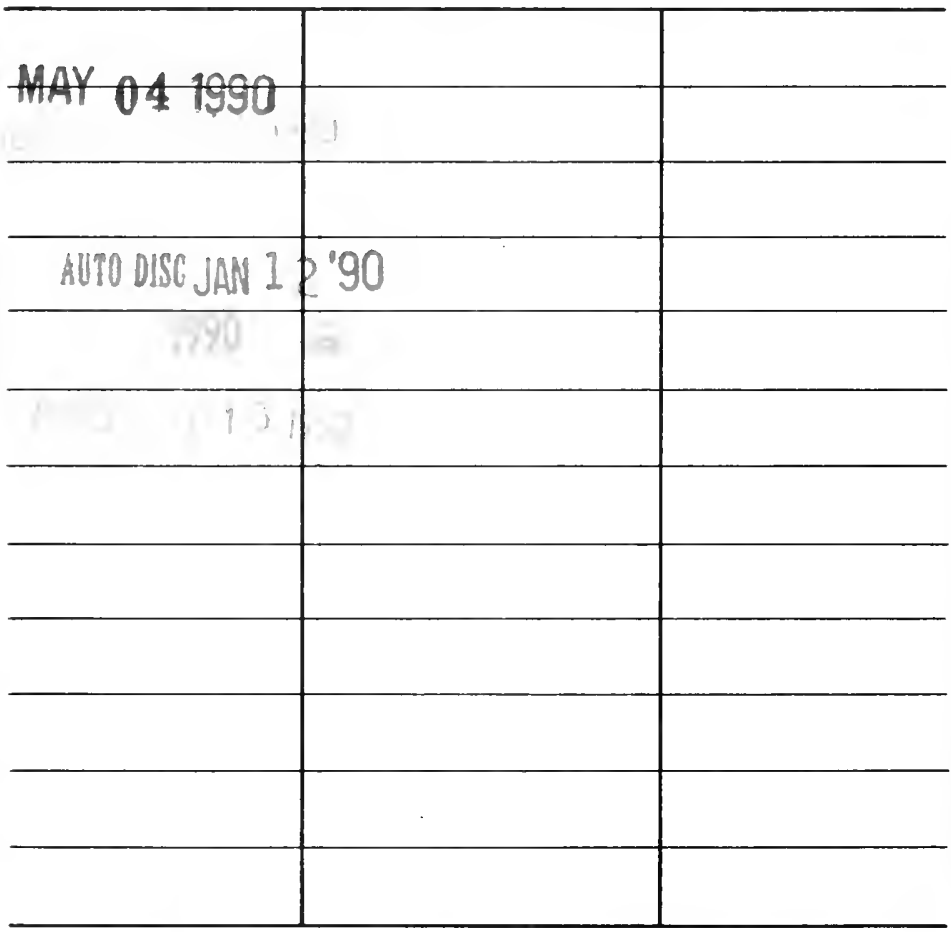

UNIVERSITY OF CALIFORNIA, BERKELEY

FORM NO. DD6 BERKELEY, CA 94720

University of Californa (P) 


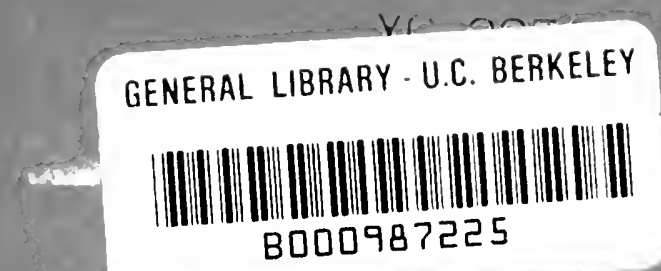

THE UNIVERSITY OF CALIFORNIA LIBRARY 
